





Presented to the

LIBRARY of the

UNIVERSITY OF TORONTO

by

JOSEPH BUIST 

Digitized by the Internet Archive in 2008 with funding from Microsoft Corporation 

WANDERINGS OF A NATURALIST 




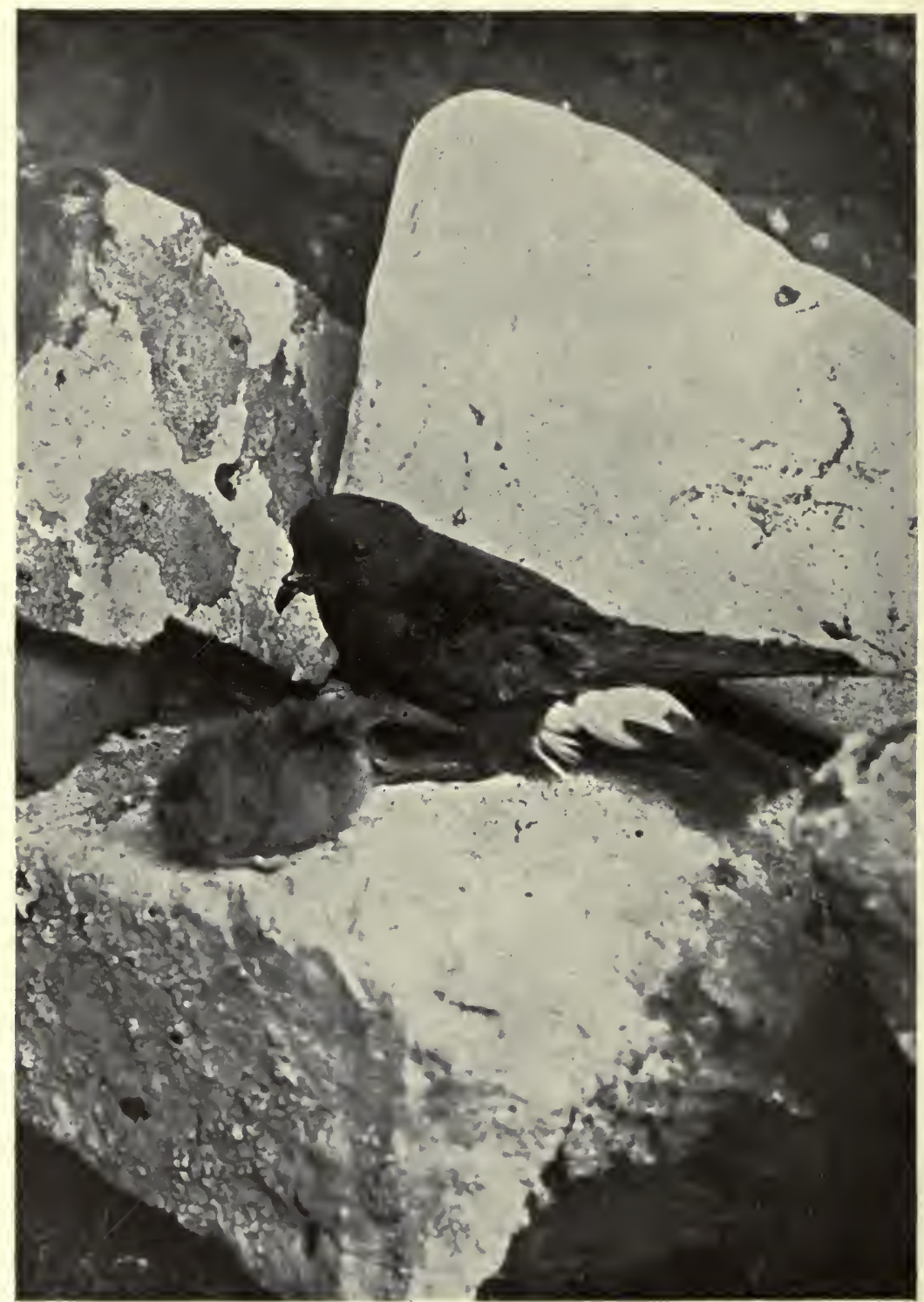

STORM PETREL AND NEWLY-HATCHED YOUNG. Note the large raised opening of the nostril. 


\title{
WANDERINGS OF A NATURALIST
}

\author{
ก By \\ SETON GORDON, F.Z.S. \\ Author of "The Charm of the Hills" and \\ "The Land of the Hills and the Glens"
}

With 78 Illustrations from Photographs by the Author and his Wife

\section{CASSELL AND COMPANY, LTD}

London, New York, Toronto and Melbourne 1921 


\section{L6FA9: \\ OCT 111994}

univeritr of torunin 


\section{In SDemory of \\ R. F. H. C.,}

Whose companionship on many a climb made the hill seem less steep

and the way less long. 


\section{FOREWORD}

T $\mathrm{N}$ these pages I have attempted to set down the varied experiences which fall to the lot of the nature lover in his wanderings. They deal chiefly with the highlands of Scotland and their birds, but the reader will find descriptions of the Northumbrian coast in winter, the Aran Islands west of the Irish coast, and a hill pass of the Pyrenees.

Many of the chapters first saw the light in the Scotsman, to the editor of which I am under an obligation for his courtesy in allowing of their reproduction in book form:

I must also here acknowledge my indebtedness to the editors of the Times, Country Life, and Illustrated Sporting and Dramatic News for permission to reproduce articles which appeared in the first place in these papers.

In the compiling of the book, and more especially in the taking of the photographs, I have been constantly helped by my wife, and the book owes a great deal to her assistance and encouragement.

SETON GORDON.

OBAN, May, r92I. 



\section{CONTENTS}

CHAPTER : PAGE

I. The Nesting of the Greenshank . • . I

2. A Hill Pass of the Pyrenees . • . . 6

3. A Spring Day at the Haunt of the Grey GEESE • . • . . . . . . II

4. A SEABIRds' IsLand IN MAY . . . . . I6

5. 'Twixt Bamburgh and Lindisfarne • • 20

6. The Golden Plover . . . . . . 25

7. A Deer Forest in June . . . . . . 30

8. The Nesting of THE MERLiN . • • • 33

9. BRAERIACH IN Midsummer . • • . 37

Io. A Nesting Haunt of THE Scoter . • . 40

II. BeinN EOlosary OF Ulva . • • • • 44

I2. The Nesting of the KitTiwake . . . 48

I3. CaIRngorm AND BEN MACDhui: A DAY ON THE HIGH TOPS • • . . . . . $5 I$

I4. The ARgyllshire COASt AND ItS Islands . 58

I5. SUnRISE FRom SgOR AN Lochan Uaine . . 63

I6. The Nesting of the Storm Petrel . . . 68

I7. Clisham: A Climb in Harris . • . . 77

18. Midsummer at the Wells of Dee . . . 8I

Ig. In Hebridean Waters . . . . . 86

20. Easaval of South Uist • . . . . 90

2I. A Feathered Criminal: The Greater Black-

BACKED GULI . • • • • • 94 ix 


\section{Contents}

CHAFTER

22. Mingulay of the Cliffis

23. The Dotterel of the High Tops . . . 105

24. A Hebridean Island and its Birds . . . II3

25. SAlmon of the LinN of DeE . . . . I2O

26. Bird Fishers of the SEA . • • . • I25

27. September on the Bass Rock . . . . I30

28. October in Lairig Ghru • • • . . 135

29. Heather . . . . . . . . I40

30. The Roaring of the Stags . . . . I43

3I. The Spawning of the Salmon . : • • I46

32. Sgoran Dubh : An Autumn Snowfall . . 149

33. Berries of the Hills . . . . . I54

34. Ben MacDhui in September . . . . I58

35. AN October Day in the Forest • . . I64

36. The Flighting of the Widgeon . . . 169

37. Croaghaun of Achill • • • . . I72

38. Garbh Choire Mhor: A Corrie in the CaIrNGORM MOUNTAINS • • • . . . I77

39. The Aran Islands: AN OUtpost of Ireland - I8I

40. Shore Birds in Late December . • . 188

4I. CAirn Toul: AN ARctic Climb . . . . 192

42. The Longstone Relief . . . . . . I99

43. A February Day on the Dee • • • . 204

44. Lindisfarne in February • • • • . 207

INDEX . . . . . . . . $2 I_{3}$ 


\section{LIST OF ILLUSTRATIONS}

Storm Petrel and Newly-hatched Young Frontispiece

GREENSHank SeTtLing DOWN ON HeR EgGS FACING PAGE Greenshank beside her Eggs and Slightly Suspicious

Young Greenshank: "About to Explore the World" 5

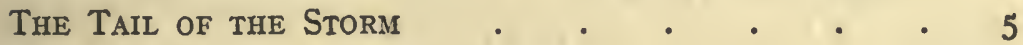

Puffins at their Meeting Ground . • . . 24

A Shag with her FUll-Grown Young • • • 25

Golden Plover: A Cautious Approach to her Nest • 25

Golden Plover: On the Alert . . . . . 28

Golden Plover: Panting in the Heat • • 28

A DeEr Forest in JUNe . . . • • . . 29

The Northern Slopes of the CaIrngorms under Snow

IN JUNE • • • • • • • • • • 29

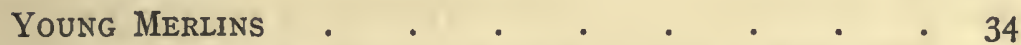

Young Merlins : Feathers Just beginning to Show • 35

The Infant Dee falling over the South Precipice of BRAERIACH AT A Height OF 4,000 FT. .' . . 48 Kittiwakes : Attentrve Sitters . . . . . 49

A Hill Burn of the Ben MacDhui Plateau half under

SNOW . . . . . . . . 56

GARbH ChOIRe MhOR . . . . . 56

Early June at the Hill-top: Sgor an lochan Uaine. 57

Storm Petrel: The Parent Birds at the Entrance to

THEIR BURROW 


\section{List of Illustrations}

Storm Petrel: The Bird and the Egg Exposed • $\cdot 72$

Young Storm Petrel about a Fortnight Old • • 73

Young Storm Petrel perhaps a Month Old . • 73

Looking North-West over the Conical Peaks of Harris FROM THE TOP OF ClishaM . . . . . 80

Fin Whale landed at the Whaling Station, Harris . 80

The TOP OF THE POOL . . . . . . . 8 I

The Welis of DeE $\quad . \quad . \quad . \quad . \quad . \quad . \quad$. 8 I

Hen Ptarmigan feigning Wounded and crouching

SNAKE-LIKE . . . . . . . . . 86

Ptarmigan Listening for her Chicks • • • 86

Sun Setting behind the Sound of Mull . . . 87

The Hazy Plains of the Atlantic . • . . 87

A Hebridean Dwelling House.$\quad \cdot \quad \cdot \quad \cdot \quad \cdot 92$

Hebridean Islanders Gathering Sand to Sprinkie on THE EARTHEN FloORS OF THEIR HOUSES • • 992

Greater Black-backed Gull on her Nest • • • 93

Greater Black-backed Gull: Forty Winks: Feeling THE HEAT . . . . . . . . IOO

Guillemots Nesting in Thousands on one of the Stacks of Mingulay . . . . . . . . IOI

Crowded Guillemot Ledges 500 Ft. above the Sea: MiNGULAY

DOTTEREL APPROACHING A NEST AT 3,200 FT. ABOVE THE SEA . . . . . . . . . I05

DotTerel on his NeSt 3,600 FT. ABOVE THE SEA • . 105

A Dotterel's Nest about 4,000 FT. Above the Sea : Sleepy AND Contented . . . . . . . . . . ro8

Dotterel: The Baby's First Appearance . . . 108

Dotterel Brooding the Young at 4,000 FT. ABove the SEA . 


\section{List of Illustrations}

Young Ravens just after Leaving the Nest

Razorbills with Four Herring Fry . . . . II4

Ringed Guillemot at Home . . . . . . II4

RAZORBILIS IN CONCLAVE . . . . . . II5

Guillemots : A leisured Tollet . . . . . II5

Puffins with SANd Eels . . . . . . II6

Puffins : Somewhat Weary . . . . . . II6

A Raven's Nest and Eggs in a Snow-clad Gully . . II7

Guillemots with their Catch . . . . 128

GanNets at the Bass Rock . . . . . . 129

Gannet : Poised . . . . . . . . . 130

Gannets at the Bass Rock: "Full steam ahead" . I3I

An Immature Two-Year-Old Gannet . . . . I3I

"Good Hunting, My Child". . . . . . I34

The Pools of Dee, with Lochan Uaine in the Dis-

TANCE . . . . . . . . . . . I35

An Autumn Snowfall on the Lairig Summit • . 148

Salmon SpaWning-Ground on the UpPer DeE • . I48

Loch EINICH AND Sgoran DubH . • • . 149

Sgoran DubH, LOOKIng North: AN Autumn SNowfall . I52

Sgoran Dubh: An Autumn Snowfall . . . . ${ }_{152}$

Sgoran Dubh: A Pilgrim in Snowy Wastes • . 153

Ben MacDhui in September . . . . . $~ I 53$

Ben MacDhui in September: Looking Westward into

COIRE ODHAR . . . . . . . . . . . I62

Loch Etchachan and Beinn Mheadhon . • . I62

AN October Day in the Forest: Across the SNowCOVERED TOPS: SPYing tHE CORRIES . . . I63

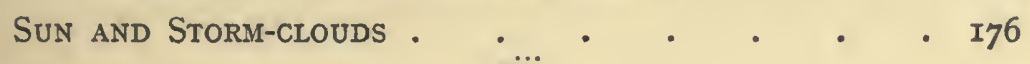




\section{List of Illustrations}

FACING PATE

Croaghaun of Achill: Looking SEAWARd From 2,000 FT. I76 CROAghaun of Achill . . . . . . . I77 GarbH Cholre Mhor: The Corrie in October ARAN ISLANDERS ROWING OUT IN THEIR CURRAGHS TO A PASSING ADMIRALTY TRAWLER • . . . . I92

LOOKING ACROSS TO CARN A' MHAIM FROM THE RIDGE OF CAIRN TOUL . . . . . . . . . 192

Cairn Toul: The Corrour Bothy and the Devil's Point 193

Cairn Toul: The Summit Cairn, ice-encrusted, at the APPROACH OF DUSK • • • • • • • I93 


\section{WANDERINGS OF A NATURALIST}

\section{CHAP'TER I}

THE NESTING OF THE GREENSHANK

THE greenshank is one of the most wary of British birds. Even the curlew is tame in comparison, and the wild and unapproachable golden plover. Thus it is that the photographing of a greenshank at her nest is a difficult feat in bird photography, and calls for a large amount of patience and perseverance. During a recent season a companion and I spent a month in a wild country of bog, heather, and ancient pine forest, where several pairs of greenshank have their home during their nesting.

Unlike the redshank, which remains in the British Isles throughout the year, the greenshank at the close of summer migrates south, and does not put in an appearance at its nesting haunts until late in March or early in April. It was May to when we arrived at the nesting ground. On the high hills the snow still lay unbroken, for the spring was a backward one, and the birches were leafless as in midwinter.

The greenshanks had apparently just commenced to sit, for on the loch side were solitary birds-presumably the cocks -feeding, and for four days we searched the most likely nesting places from morning to night without success. The weather during this time was cold and very rough, and we had begun to despair of success. But on the afternoon of the while sitting near a loch where all the greenshanks of the shanks of the district fed, one of them, rising from his dinner, 


\section{Wanderings of a Naturalist}

flew, calling, across the forest near us, and disappeared a few hundred yards away, having evidently dropped to the ground. We surmised a nest must be near, and on reaching the spot, which had been by no means easy to mark, the greenshank rose, settled for a moment, obviously surprised at our sudden appearance, then took wing uttering anxious cries. A very careful search was made over all the neighbouring ground, and at length we were rewarded by finding the hen greenshank sitting on her nest. Although we were not more than six feet away the bird crouched flat and absolutely motionless on her eggs, relying on her wonderful protective colouring and evidently thinking she was invisible to our eyes. The nesting site was under a large dead pine branch, the nest being placed amongst some of the small side branches. Four eggs, handsomely coloured and marked, were in the nest, and in appearance were quite distinctive and unlike those of any other "wader."

The following afternoon a "hiding tent" was erected some little distance from the nest, but on returning to the spot next day we found two collectors on the ground searching for greenshanks' nests. After a slight "brush," on our explaining that we had already found a nest and wished to photograph the sitting bird, a friendly arrangement was come to, and the collectors transferred their energies elsewhere.

But the following morning-May 17 -on reaching the greenshanks' nesting ground, we found the nest to all appearance deserted, presumably owing to the disturbances of the previous day. The eggs were cold to the touch and covered with drops of water from a shower which had passed over earlier in the morning. Thus, on revisiting the nesting site on the 19th, with little hope of seeing the nest occupied, we were delighted to find that the greenshank had returned and was sitting as closely as on the occasion on which the nest was first found. On the morning of the 20 th we moved the tent closer to the nest, and again in the evening. The 


\section{The Nesting of the Greenshank}

greenshank, on flying off, alighted on the top of a fir tree near, repeatedly uttering her wild cry. By May 23 the hide was moved to within fifteen feet of the nest. It was covered over with layers of fir branches, and was so inconspicuous that it was difficult to see until one was almost upon it. On this day I entered the tent, being covered in afterwards by my companion, who walked on past the nest to distract the bird's attention. After calling loudly the greenshank walked silently up and settled unsuspectingly on her eggs. Upon my imitating, or attempting to imitate, a curlew's whistle, she left the eggs instantly, but quickly returned, nor would she move again even although the same whistling was repeated loudly and frequently. She seemed to think the noise came -as it should have done-from the sky, for on hearing it she looked skyward.

On May 26, a day of brilliant sunshine and tropical heat, the sitting greenshank was again visited, and the hidingtent moved to about eight feet from the nest. After I had been closed up in the hide the greenshank quickly returned, but this time she was wary, not liking the look of the lens which peered out at her through a hole cut in the front of the hide. At the end of ninety minutes she had not ventured on to her eggs, and my companion then returning to hear how I had fared, I decided that a further vigil would be necessary. Curiously enough, this second time, the mother greenshank returned within five minutes to a point a foot or two from the eggs, but lacked courage to settle down on them.

She brooded imaginary eggs in other places, but the eye of the camera staring at her, Cyclops-like, was too much for her nerves. Not many minutes elapsed before her mate flew up and settled on a dead branch a few yards off, speaking soothingly to her in soft and very musical flute-like calls. Then he walked past close to the eggs, apparently in the endeavour to discover the cause of his mate's alarm. Calling softly to her he took wing, whereupon she joined him and 


\section{Wanderings of a Naturalist}

they both flew across to the loch side to feed. The hen returned after about fifteen minutes, but instead of brooding her eggs-knowing, no doubt, that in the warm sunshine they would come to no harm-stood motionless near the nest, dozing.

At last she did brood the eggs for a few minutes, panting continuously by reason of the great heat. The cock during this time flew up into the air with quick wing beats, uttering flute-like calls very much after the manner of the redshank during its nesting season, but the notes were deeper and more musical than those of the latter bird.

On this date, May 26, two of the eggs were just commencing to chip.

On May 29 the eggs were still unhatched, but one of the chicks could be heard hammering on the shell. The greenshank was now comparatively indifferent to the hide, returning almost at once to the nest, and, after calling repeatedly with short, sharp whistling cries, walking confidently on to her eggs. On the afternoon of May 30 we found, on visiting the nest, that the small greenshanks had hatched out. I entered the hide at 3.30 p.m. and remained till 5.5 p.m. The mother greenshank seemed very proud of her young family, brooding them contentedly and pecking occasionally at a piece of broken eggshell lying just outside the nest. At $4.50 \mathrm{p} . \mathrm{m}$. she suddenly sprang up on the nest, then flew off calling. The cock had arrived.

She soon returned, however, and had trouble with one of the chicks, which was restless and would not remain beneath her. On these occasions she would push it gently under her breast with her bill.

Early on the morning of May 31 we visited the nest for the last time. The chicks were still beside the nest, but about 9 a.m. the mother greenshank led her young brood away to a rush-fringed pool for their first feed. Here we left them, wishing them well and hoping that they would be successful in avoiding the many dangers that beset the chicks of ground 


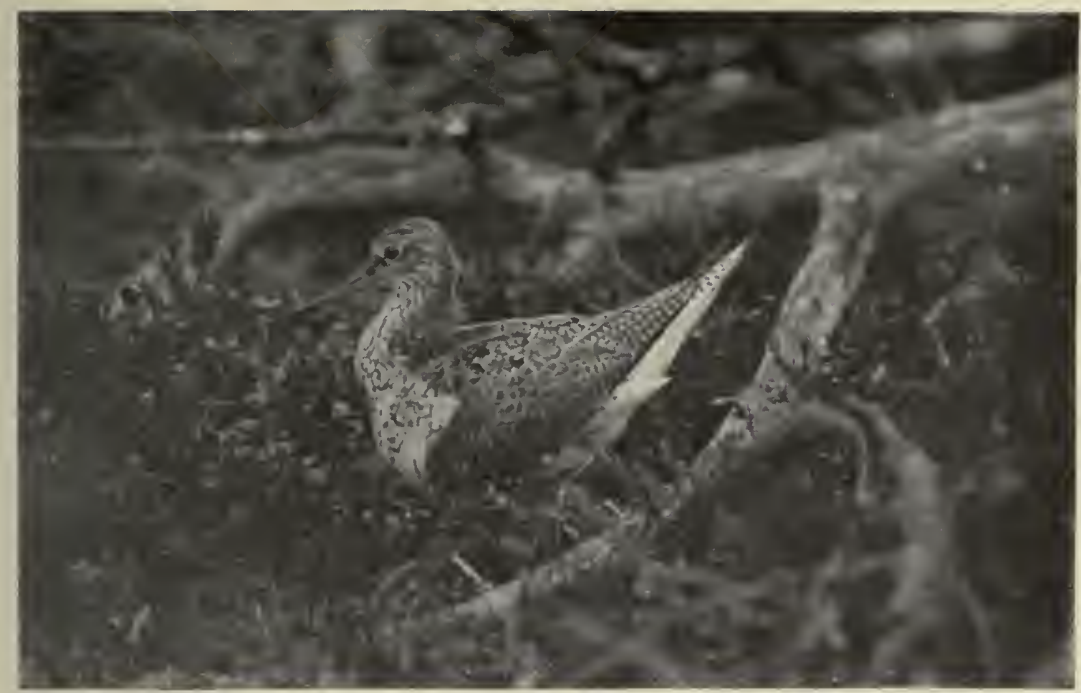

Greenshank Settling Down on her Eggs.

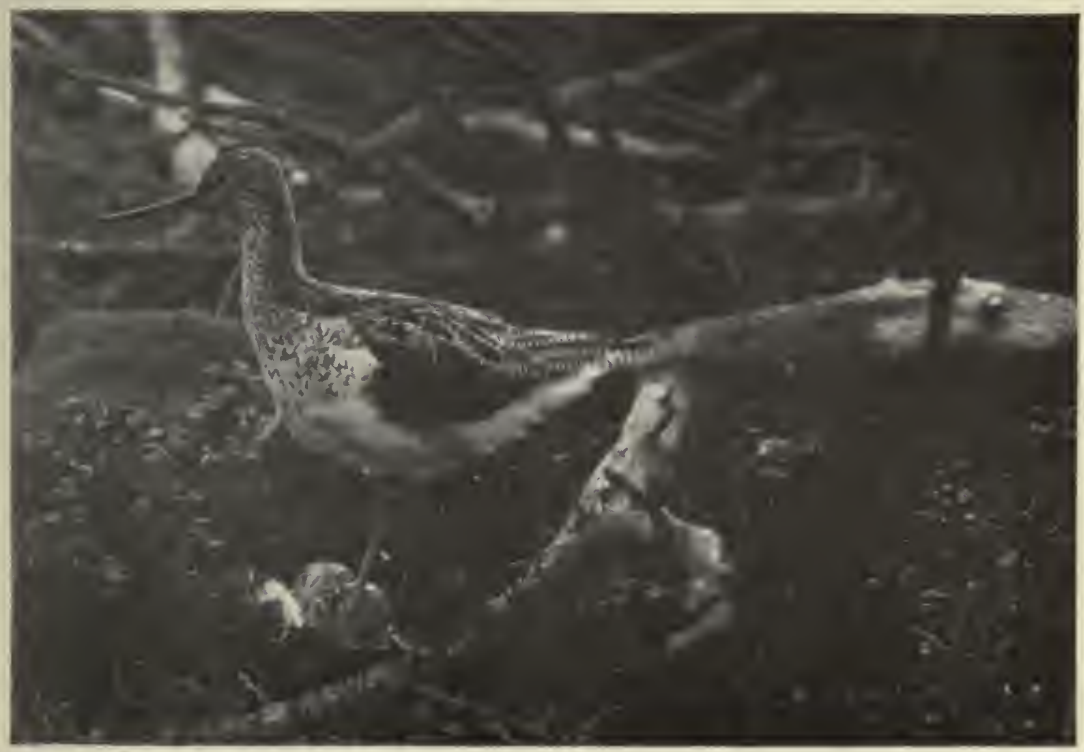

Greenshank beside her Eggs and slightly Suspicious. 


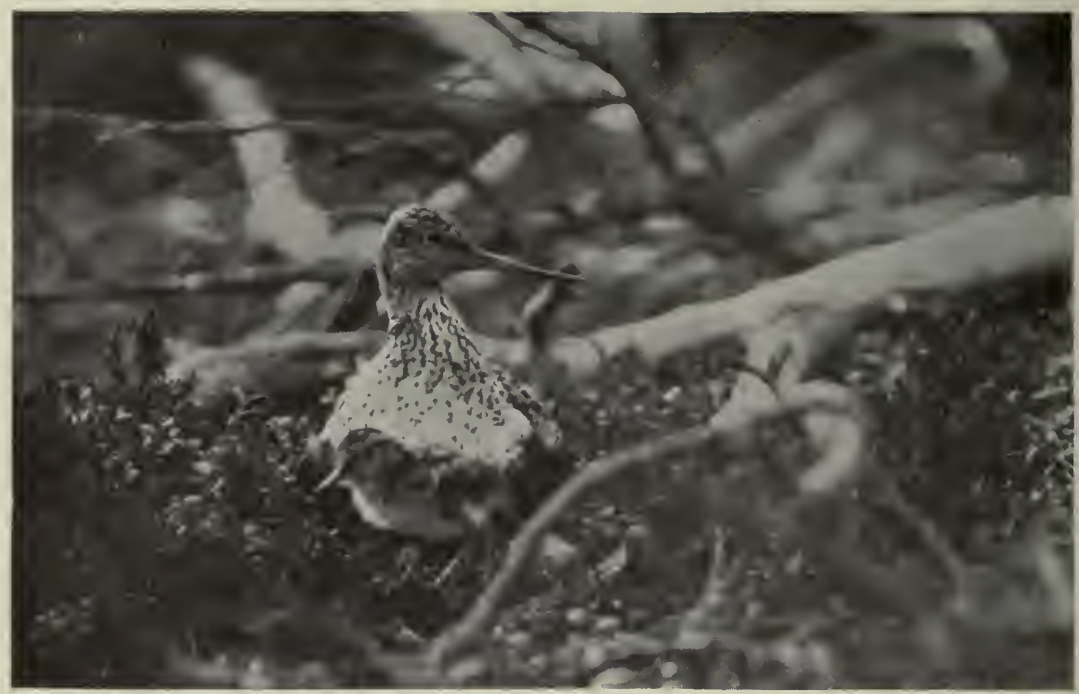

Young Greenshank: "About to explore the world."

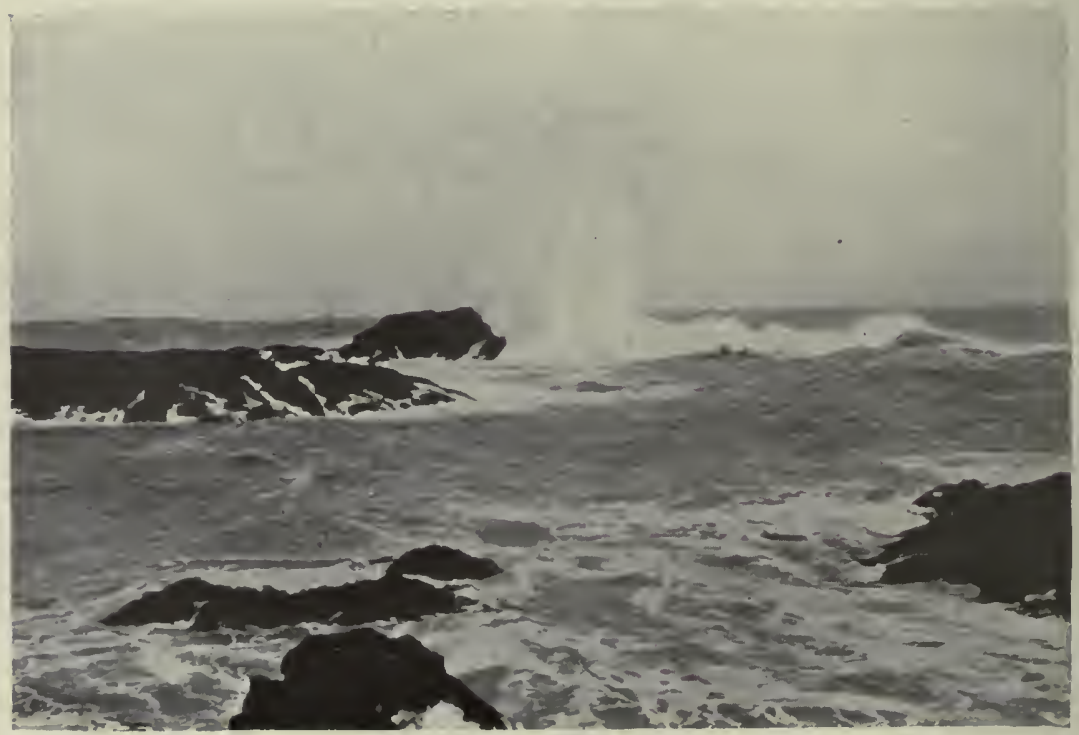

The Tail of the Storm. 


\section{The Nesting of the Greenshank}

nesting birds. Not long afterwards a great forest fire swept the district. It passed perilously near, though not actually over, the haunt of the greenshank, and although we did not afterwards see the brood, we hoped that they escaped the tragic fate which had overtaken so many of the forest inhabitants. 


\section{CHAPTER II}

\section{A HILL PASS OF THE PYRENEES}

N April morning at an altitude of 4,000 feet above sea level. In the hollows the winter's snow still lingered, reflecting from its surface the rays of the early morning sun, and even on the wind-swept slopes where the snow had melted the grass was brown and devoid of the beginnings of growth. Southward a giant corrie or "cirque" shut out all distant view, the rocks rising almost sheer to a height of 9,000 feet. It is down these rocks that during the months of summer a hill burn falls in a white cascade, blown to and fro by the mountain winds. Now its waters were firmly held in the grip of the frost and the course of the falls was marked by large expanses of blue-green ice.

It was early morning when a companion and I left the village of Gavarnie. For the season the temperature was warm beyond the ordinary, and though the south wind reached us after a passage over snow-clad tops, there was no bite in its breath. It brought with it, rather, a taste of the great arid Sahara, whence it had its origin, and where is clrought and an absence of living things. Our way first led :cross a steep hill face, so steep that the snow had alreauy been dispersed by the sun's heat. In places Saxifraga oppositifolia-that Alpine plant known to the lovers of Scottish hills-only a few days released from its covering of snow, was already opening its rich red flowers, careless of the frost or snow which would surely cover the hills again before the arrival of summer. At one point a gentian had forced its way through the grass and had opened a flower of the deepest blue $\rightarrow$ a flower that, amongst the arid grass wastes, compelled attention and admiration. 


\section{A Hill Pass of the Pyrenees}

The snow-line was soon reached, at a height of little over 4,000 feet. Here a wide view opened up in a northerly direction, and snow-covered hills stood out sharply. A pair of snow buntings flitted quietly past. They had little fear, settling on some rocky ground from which the snow had already disappeared, and through the glass could be made out plainly. 'They had not assumed the nesting dressthe cock as yet lacked the striking black and white plumage and black bill and feet which mark him conspicuously during the time of his nesting-but I was informed by my companion that the birds do actually nest in the district. From a steep, rocky face above us were borne curious, chirping cries, and, as we approached, numbers of Alpine choughs circled around. Their nesting sites were still snow covered, but their descent to the lower ground was a none too favourable sign for the continuance of fine weather. And now we walked forward through an unbroken waste of snow, from which life of any kind was entirely absent, though in the snow we found at intervals feathers of the ptarmigan, which in the high Pyrenees, as in Scotland, has its home on the roof of the world. I believe that in the Pyrenees the ptarmigan reaches a greater size than in its Scottish haunts, but I did not succeed during my visit in obtaining a sight of the species. For some miles the way led steadily upwards until, at a height of 8,000 feet, we reached the watershed and the boulder which stands there as the boundary between France and Spain.

All around us the sky was dark and lowering. To the north squalls were already descending on the hilltops; south the hills were clear, but the sky was of that inky hue which presages a storm. Above us the green mass of a glacier could be distinguished against the snow, a glacier which withstands the sun's heat through the summer months; but of life there was no sign, save a lonely chough which flew screaming from a rocky gorge. The descent into Spain is, I imagine, an easy one when no snow lies on the ground; but when we made the expedition an average depth of many 


\section{Wanderings of a Naturalist}

feet lay on the hill, and with the surface half thawed by the soft wind-which at times blew with the force of a whole gale-the going was exceedingly stiff. Standing at an elevation of 7,000 feet and fully exposed to the storms was a wood of true mountain pine-Pinus montana uncinata. The outskirts of the wood were guarded by veteran trees, evidently of great age but now dying. It was of considerable interest to notice that their trunks showed the phenomenon of spiral growth well marked, the phenomenon which can be noticed in some of the outlying Scots firs in Glen Derry and Glen Quoich in the Highland Forest of Mar. It is to meet the great strain put upon the wood by incessant gales that this picturesque spiral growth is formed.

Of all the trees of the Pyrenees the mountain pine is the one which best resists the storms of winter at high elevations : the Scots fir, though hardy enough, does not penetrate to near the limit of tree growth and is found in the comparative shelter of the valleys. Well below the forest of mountain pine-around the 5,000-foot level-we passed through a thick growth of yew trees. The specimens did not approach the dimensions which are attained by this species in England, but to me it was of interest to see them for the first time in a natural state. It is well known that the leaves are immediately fatal to any sheep which is unfortunate enough to swallow them.

A rapid descent brought us to a deep valley with precipitous hills on either side and a swift-flowing river, with semiopaque waters of the blue tinge that denotes an icy source, hurrying southwards. Here tree-growth was luxuriant, and on either side of the burn Scots firs stood strong and straight. We were now no more that 4,000 feet above sea level, and at this relatively low altitude I noticed the mountain pine was entirely absent. Rain was falling heavily, and about the hilltops the mists were gathering, foretelling a continuance of the storm. A long walk down the glen still lay before us, and under fine-weather conditions the scenery must have 


\section{A Hill Pass of the Pyrenees}

been superb. From the heights above, cascades broke in spray at our feet. The main river thundered through its narrow cliannel, holding in its deep pools trout of great size. Before us, now and again, a water ouzel darted down stream, flying only a few feet above the water, as is its habit; and once, making its way southwards at a great height, I saw what might have been a booted eagle, but the distance was too great to permit of identification.

At length, after a twenty-mile tramp, we reached our home for the night and found a Russian hunter, who had taken up his quarters in this wild spot for the stalking of the "izard" (chamois) and an ibex-Ibex pyrennaica-which, I believe, is now well-nigh extinct in the Pyrenees, as, indeed, throughout Spain. Its decrease has apparently been brought about, not so much by the rifle of the stalker, as by the inroads of illness caused by the migration of domestic goats into its haunts.

Accompanying the Russian was quite a retinue of stalkers -a fine, healthy body of men, carrying, each of them, the orthodox stalking-glass of the Highlands. During the week the party had been installed at the inn a few chamois had been seen, but not a single animal of any kind had been secured. Next morning it rained in torrents, but just before the hour when we started out on the return journey, the sky lifted somewhat and we had hopes of a good day. But before we reached the head of the glen and commenced our climb across the "col," a northerly gale had sprung up and was bringing with it sheets of rain, while on the hilltops the drifting snow could be seen caught up into the sky in powdery clouds. As we started the climb a company of swallows swept round from the storm-swept sky into the shelter of the hill face. Flying from a northerly direction, the travellers had evidently essayed to make the northward crossing of the pass on the way to their summer quarters, but had been driven back by the violence of the storm and the blinding drift.

Gradually we left the sheltering hillside and found our- 


\section{Wanderings of a Naturalist}

selves fighting our way upwards against a full gale of wind and blinding clouds of spindrift. At first the snow melted as it fell, revealing many plants of the purple mountain saxifrage in full bloom and holding up their flowers bravely to the storm. One cannot but wonder that this beautiful Alpine plant should choose as its flowering period the very moment the winter's snows have disappeared from the hills. Such disappearance is almost always a temporary one only, and the hills a fortnight later have too of ten assumed their winter mantle once more, burying deep the rich flowers of Saxifraga oppositifolia in their icy covering. As we pressed onwards we noted that luxuriant shrubs of boxwood-Buxus sempervirens -still held themselves above the snow, but soon we were moving slowly and painfully across an unbroken mantle of white, with the drift so thick that it was impossible to see any distance ahead. We were encrusted with ice from head to foot-even breathing was difficult owing to the violence of the gale. The snow, too, was soft, and this added greatly to the difficulties of the journey. But, at length, thanks to skilful guiding,' the frontier was gained-where, so great was the force of the wind, the ground had been swept almost bare of snow-and towards evening the village of Gavarnie was reached and the country of the snows left for a season. 


\section{CHAPTER III}

\section{A SPRING DAY AT THE HAUNT OF THE GREY GEESE}

FINE spring day in late March. For a full week the wind has been blowing half a gale from the west or south-west, but on the morning of which I write it is moderating, and the air is of an exceptional clearness, with deep blue sky flecked with white fleecy clouds. Westward, big snow wreaths linger on the Cheviots-the result of a recent storm from the north-and from the nearer hills blue smoke rises from more than one heather fire.

The scene is the remote and wind-swept Ross Links on the Northumbrian coast between Bamburgh and Holy Island, a paradise for all shore-frequenting birds from September until the early days of May. The spring is far advanced, and already the hedges are green in sheltered spots, and the daffodils in bloom in the farm gardens. Farmers are everywhere sowing, harrowing, or setting in their potatoes, and the season promises uncommonly well. Along the Ross Links many lapwing nest. The period of their laying has as yet barely commenced, but the air resounds with their joyous cries, and it is good to see their fine dashing flight as they wheel and tumble through the air, feeling to the full the impulse of life and of springtide.

For awhile I lie in the shelter of a thorn hedge, spying the adjoining field for any early nesters among these birds, when all unsuspectingly a flock of about forty grey geese, flying in from the eastward, alight in the field and at once commence feeding. Very graceful did they look as they flew deliberately up in the teeth of the breeze, and now they graze actively on the fresh young grass. Every now and again they 


\section{Wanderings of a Naturalist}

cease feeding, standing erect and on the alert, but they can see nothing suspicious, so resume their meal. I am interested in noting that they feed just as readily down as up wind, though in the former position-a position which most birds are reluctant to assume-the strong breeze ruffles their feathers considerably. After about forty minutes' continuous grazing the geese, one by one or in small companies, walk over to where a pool of water lies on the field, the result of a recent storm. Here they drink copious draughts with evident relish and, refreshed, resume their feeding. An hour and a half after their arrival I can count sixteen out of the forty resting on the grass, some of them asleep with heads tucked away among their feathers. One bird is too lazy on awaking to rise to his feet, and crops the grass as he rests on the ground. One or two individuals enjoy a bath in the pool, throwing the water over their backs with great gusto, and forcing it beneath their wings. Their bath over they waddle to the edge of the pool, flapping their wings vigorously.

Although so many of the geese are together, the birds feed in complete harmony, and on one occasion only during the hour and a half's close observation do I see an individual show any signs of hastiness of temper. Near to the grey geese many lapwings are courting and "displaying," and three brown hares are sparring. In the little pool a pair of redshank are feeding, and a curlew stalks sedately near.

I expect the geese to rest awhile after so prolonged a spell of feeding, but after a few minutes those asleep rouse themselves, stretching wings and legs, and recommence their grazing. Suddenly, for no apparent reason, the whole company rises together with many honking cries pitched in far different keys, making for the Fenham Slakes, where they alight near the edge of the water, many of their number again dropping off to sleep. But their dozing is soon interrupted by the quickly flowing spring tide. At first the geese endeavour to avoid the incoming water by walking towards the 


\section{At the Haunt of the Grey Geese}

shore, but becoming tired of this, and being scarcely able to keep pace with the tide, allow themselves to be overtaken, and dip down to feel the coolness of the sea, ultimately swimming in a body a short distance off shore.

I have advisedly spoken of these birds as "grey geese " as, unless a near view is obtained, and that under the best conditions of light, it is almost impossible to identify them with certainty.

Three species of geese-grey lag, pink-footed, and beanare commonly known collectively as "grey geese." In size, and in the colour of their legs, the three species have distinctive peculiarities; but these cannot be readily determined unless the bird is shot. If a good view be obtained of the geese through the glass, perhaps the surest method of identification is by the bill. In the grey lag this is tipped with white, and in the bean and pink-footed with black. Of the two latter species, the bean is usually the larger of the two, the bill is not so short, and there is a wider band of black about the basal portion. The true grey lag-although the three species are habitually referred to by shore gunners as grey lags-is comparatively rare along the Northumbrian coast.

I am just able from where I lie to make out the black tip of the bill of one of the feeding geese, but I am not sufficiently near to be certain whether the birds are of the pink-footed or bean species, though I am inclined to think the latter. Neither the bean nor the pink-footed goose breeds as far south as our latitudes. The former is supposed to nest in North Iceland, and the latter has been found breeding in Spitzbergen.

It is curious that the grey geese should remain at their winter quarters at a time when their relatives, the brent geese, have all taken their departure, for the breeding grounds of the last-named lie fully as far to the north as those of the grey geese.

In February hundreds of brents and thousands of widgeon 


\section{Wanderings of a Naturalist}

frequent this estuary. To-day not a single one is to be seen.

Many shore birds are feeding this morning on the flats, and the flowing tide moves them up to my place of concealment, so that I have an excellent view of them in the clear sunlit air. At the water's edge godwit run actively about, thrusting their bills repeatedly into the muddy water as they feed. The godwit is always full of restless energy at its feeding ground, and quite unlike its larger and extremely deliberate relative, the curlew. With the godwit are numbers of dunlin and a few knot. As the tide encroaches too near the edge of the flats the godwit and knot fly off, and perform wonderful evolutions overhead, swerving and wheeling, and as they make a sudden sweep, the sun transforms their pluniage to silver as though by magic. Now they race down wind at express speed, now hover against the breeze, each bird keeping perfect station. The grey plover and dunlin seem for some reason to feed on till nearer full tide than the knoi and godwit, and as they are forced nearer the shore my glass brings them very close. The grey plover are still in their winter plumage. There is as yet scarcely a suspicion of the handsome black breast which renders this bird so conspicuous during its nesting season in the Arctic, nor have the dunlin commenced to assume their summer dress. The plover stalk warily around, their movements, deliberate and graceful, being in striking contrast to the fevered activity of the tribe of the dunlin.

From time to time one of the plover captures a marine worm, dragging it from its lair in triumph and proceeding to enjoy its succulence. Shelduck are courting on the sands near me, performing ludicrous antics in their excitement as they pursue each other with necks outstretched to their fullest capacity and heads almost touching the ground.

On high many larks are in song, and a redshank from the boggy field, where it will presently nest, flies up into the air and sinks again on drooping wings, all the while uttering 


\section{At the Haunt of the Grey Geese}

its flute-like song. By early afternoon the spring tide is at the full, and all the mud flats are covered. The last of the grey plover and dunlin have been driven from their feeding, and the grey geese have gone, with many honking cries, to their inland feeding ground. But in the air are still the cries of many lapwing, the songs of many larks, and the whistle of redshank as a perfect day of spring draws towards its close. 


\section{CHAPTER IV}

\section{A SEABIRDS' ISLAND IN MAY}

$\mathrm{O}$ $\mathrm{N}$ a fertile island lying a little way into the Irish Sea seabirds in their thousands congregate during the season of their nesting, so that the air here resounds with their cries, and over the surf that breaks upon the rocks puffins and guillemots fly in never-ending streams throughout the hours of daylight.

It is in April that the birds arrive off the island-for at first they do not visit the land-and by mid-May the majority are busy with nesting cares.

It was on the sixteenth day of the latter month that I paid my first visit to the island. Early in the morning mist lay thick over the sea, but with the gathering strength of the sun this had cleared away before we set sail, and the island stood out before us distinct against the northern horizon.

Solan geese made their way past our boat on tireless wings, shearwaters dipped with most graceful flight through the southerly swell, and sea swallows fished daintily, stooping with sharp cries and unswerving aim on the surface-feeding fry. Strings of guillemots crossed our track, making for their fishing grounds and flying, as is their custom, only a few inches above the water's surfäce; but it was not until we had anchored beneath the dark rocks of the island that the first puffins were seen. Landing in one of the sheltered bays -for the south wind blew strong-a short walk took me to the hill-top, where, on the cairn, the peregrine is wont to sun himself, and where in the heather and bramble plants stonechats rear their broods, and whitethroats flit noiselessly as they busy themselves at their nest-making. Great fields of 


\section{A Seabirds' Island in May}

wild hyacinths covered the hillside, so that the air was heavy with their scent, and the quickly springing bracken fronds, which soon would cover the hillside in a thick canopy, could scarce be seen for the luxuriance of the bluebells and primroses that grew between them.

Making my way to the western end of the island I came on a colony of puffins. I do not think many of the birds had laid as yet, but they were working at the excavation or repair of their burrows, and as I approached many of them emerged in their comical manner, to fly out to sea with outstretched feet, as is their custom. Thousands of herring gulls had their nests amongst the grass and heather here, and wheeled about me in a great cloud with many wild cries. At one point at the top of the cliff a small colony of razorbills and guillemots had just commenced to lay. Only a few of their number had eggs, laid on the bare rock in such a position that a vigorous jerk must precipitate many into the sea beneath. Some of the eggs of the guillemots-freshly laidwere of a wonderful sky blue ground colour, which contrasted vividly with the dark rocky shelves on which they lay. The razorbills were a little later in their nesting. I saw but one egg, hidden away in the dark recess of a cranny among the rocks, and already soiled with the wet mud on which it lay. Compared with the egg of the guillemot, that of the razorbill is not so pointed, and so must be laid in a more secure position than that chosen by the guillemot, for the egg of the latter bird from its shape spins round on its axis in a remarkable manner, and of its own accord rarely indeed rolls off the cliff.

Near the guillemots a large colony of cormorants were brooding their chalky blue-white eggs, sitting contentedly on their bulky nests, from which was wafted on the breeze a strong smell of mustiness arising from the remains of halfdigested fish. Two of the cormorants' nests already held young birds, one brood fully a week old. Curiously enough, I was informed that the gulls here rarely carry off the 


\section{Wanderings of a Naturalist}

cormorants' eggs while the birds are absent from their nests, though on the Farne Islands clutch after clutch is destroyed by the gulls. Indeed, on these islands as late as August the cormorants are still endeavouring to hatch off their eggs, perhaps the third or fourth sitting, while the gulls with fullgrown young are still ready to abscond with any egg that is left unguarded even for a minute.

Not far from the cormorants a few shags were brooding their eggs, but I did not see more than half a dozen of these birds in the whole island.

Passing a rocky promontory, I heard, mingled with the shrill clamour of countless herring gulls, the hoarse cry of a greater black-backed gull, and after a while succeeded in identifying the bird among its many smaller cousins, which, indeed, appeared to bear it little good will-doubtless because of its egg-stealing proclivities. The nest, built beside many of those of the herring gull, showed no distinctive marks, but the eggs were considerably larger, and were covered with much larger blotches. Altogether I saw three pairs of greater black backs, two of which had eggs, while the third appeared to be nest-building.

On the eastern side of the island, where the rocks were sheer, a colony of kittiwakes were building. In no case had any eggs been laid, but many of the nests were nearly completed; indeed, one bird sat so close that before she flew off from her empty nest I made sure she must be brooding. On the same cliff were many guillemots-most of them engaged in settling their claims to the most sought-after ledges, though a few had already dropped their eggs-and a number of razorbills.

A little beyond this bird colony a peregrine had her nest on a ledge in the rock near its highest point. To-day it was the tiercel who was doing the duties of incubation, for he flew screaming from the eyrie, just as his mate soared from the cliff a few yards away to mingle her cries with his. In the eyrie were two beautifully coloured eggs, reposing in a slight 


\section{A Seabirds' Island in May}

hollow scraped in the grass, and having no lining of any kind. The gulls nesting near paid little heed to the screeching of the falcons; presumably they had become used to their presence there.

The day was drawing to a close as we set sail for the mainland. The breeze was contrary, and the passage slow and by no means comfortable, for a short choppy sea was running; but after much tacking we at length made the harbour as the sun was sinking behind the hills of Wicklow on the western horizon. 


\section{CHAPTER V}

\section{'TWIXT BAMBURGH AND LINDISFARNE}

70 those passing on their lawful occasions upon the sea, as to those travelling by road or rail, the two ancient -and now restored-castles of Bamburgh and Lindisfarne are prominent landmarks. They look perhaps at their best when seen in the clear light of early morning from the high ground beyond the Scottish Border a few miles north of Berwick-on-Tweed, Bamburgh, from its greater bulk, appearing to be almost as close at hand as the lesser, though nearer, castle of Lindisfarne. The stretch of coastline adjoining these two castles is a wild and unfrequented one, and, summer and winter, is the home of many birds. Here, during the winter months, the tribe of the grey geese-the grey lag, bean and pink-footed-have their home on the grassy fields fringing the Ross Links, remaining here till mid-April, when the north-flying impulse stirs them and they start off on their journey to far Spitzbergen, or, perhaps, the tundras of Siberia. But with their going, and with the departure of the grey plover, knot, dunlin, and the like for their summer quarters, there arrive other birds to take their places, so that this stretch of coastline is always a district abounding in life.

One soft, cloudy morning of early April a companion and I set out on the walk from Bamburgh to Lindisfarne. The spring had been a very forward one, and the hedges of hawthorn fringing the road were already almost in full leaf. A gentle breeze from the south-west just stirred the trees, and seawards the air was very clear, so that the Farne Islands stood out plainly as we reached the high ground above the 


\section{'Twixt Bamburgh and Lindisfarne}

castle of Bamburgh. The Megstone Rock harboured many cormorants, which, through the glass could, even at this distance, clearly be seen as they busied themselves with their nest-building, and on the grassy slopes of the more outlying islands lesser black-backed gulls, newly arrived from their winter quarters, could be seen resting in their hundreds. As the crow, or, perhaps, as one might more fittingly say, the solan, flies, the distance between Bamburgh and Lindisfarne is not much above five miles; but unless the tide be low the pedestrian is forced to make a wide detour, for the estuary of Budle, a somewhat dull and uninteresting spot, lies in the way.

On the north side of this estuary many primroses were in flower on the grassy banks, and among the tall hedges willow warblers flitted, from time to time tuning up their notes, though their sweet song was as yet feeble after their long overseas flight. Here, too, a carrion crow was brooding her four speckled eggs, being pursued with vigour directly she left her nest by the adjoining community of nesting lapwings.

As we reached the wide Ross Links many redshank hovered tremulously overhead, uttering their quickly-repeated, flute-like song, or else piping in alarm as their nesting site was approached. We discovered no fewer than four of their nests. In no case had the full complement of eggs been laid, while in the vicinity of every nest with eggs were-as is usually the case with the tribe of the waders-several scrapes, made before the final selection was decided upon. In one instance a redshank's nest was found within ten feet of that of a lapwing, this being unusually close for two birds of different species to nest.

Crossing the Ross Links and travelling at express speed a flock of dunlin passed us on their northward migration, eagerly pressing forward towards their goal. On the Fenham Slakes, that great extent of mud that stretches away for miles south-west and west of Lindisfarne, the tide was low, 


\section{Wanderings of a Naturalist}

and here were a few gulls with several pairs of shelduck near them, and a couple of herons stalking sedately on the ooze. A flock of bar-tailed godwits-Arctic nesting birds and so late in leaving our shores-flew uncertainly hither and thither, being apparently strangers recently arrived on this part of the coast and pausing awhile on their northward flight. With them, as is nearly always the case, were three or four knot. By now the wind had increased and blew strong from the west, and as we crossed the stretch of sea lying between that part of the mainland known as the Beacons and Lindisfarne or Holy Island, the flood-tide, running in against the wind, was sending "white horses" dancing across the bay.

That evening, in the shelter of Lindisfarne Castle, I lay awhile, watching through the glass the interesting and varied bird-life that thronged the island and its waters. On the emerald-green grass just above high tide a couple of ringed plover were feeding, and with them a dunlin, handsome in full breeding plumage, his jet-black breast contrasting strikingly with the grass on which he was searching for his supper.

Solan geese, gliding on sturdy wings, were making their way singly from the Bass Rock to their fishing grounds, flying close inshore and banking steeply and most gracefully with the true poetry of flight as a squall of wind struck them. Sandwich terns already frequented the estuary in some numbers, although they must have been hard put to it to make a living out of the few sand-eels which were as yet appearing on the surface waters. That season the sandwich tern arrived off Lindisfarne earlier than the fishermen had ever known, the first bird being seen on March 24. Out to sea a small flock of scoters were being drenched with spray every second or so, but seemed to be indifferent to this discomfort, though when a larger wave than usual was about to break upon them they dived simultaneously to escape it. On the rocks covered with sea wrack were feeding numbers of turnsivines, some of the birds in almost full breeding 


\section{'Twixt Bamburgh and Lindisfarne}

plumage, their back feathers of a rich reddish brown and legs of scarlet making them pleasing objects to watch.

In one of the fields near the castle, late in the evening, I stalked a very unusual bird, one which I do not think has ever previously been recorded on Lindisfarne. The strange visitor was in a field of sprouting oats, and on being alarmed crouched low with long neck held erect. In size it was, I should say, a little smaller than a hen capercaillie, and on taking flight showed conspicuous white wings. In flying the wings were held somewhat pendulously, and its wing beats were rapid, though not powerful. It was apparently of the tribe of the bustard, and although I am unfamiliar with the species, I imagine the bird was a hen little bustard, a bird of which there are few records along our coasts, and scarcely any so late in the season as April.

Towards evening the wind dropped, while out to sea great masses of cumulus clouds betokened thunder. After dark, from the terrace of the castle I watched awhile the young moon shedding her rays on the dark waters beneath. Away out to sea the flashing light of the Longstone stabbed the gloom with its powerful rays, and near it shone the lesser light from the Inner Farne. South of us the red beacon on Bamburgh point glowed dimly. The wind, now strong from the west, roared about the old chimneys, but in the open hearth was a great fire of wood, so that a genial warmth pervaded the gallery in which we sat, and pungent and pleasant smells from the glowing embers. Through the night, with a quickly rising glass, the wind veered north, and morning broke clear and almost cloudless, though with a heavy sea running. Only one of the Lindisfarne boats ventured to sea, and she had a very rough time of it as the men worked at their crab-pots off the north end of the island.

From the battlements of the castle there was on this day an unsurpassed view of the Northumbrian coast. In the bright sunlight Cheviot stood out clearly, with two wreaths of winter snow still lingering on its east-facing slopes. Northward lay 


\section{Wanderings of a Naturalist}

the town of Berwick-on-Tweed, enveloped in a thin cloud of grey smoke, while away to the south were the Farnes, on which the swell broke in white drenching showers of spray.

Between Lindisfarne Castle and the nearest point of the mainland, namely the corner of the Ross Links, there lies a stretch of water perhaps a mile across. The tide was full, but from the waters there emerged two small islands, one crowned with a minute area of bent grass. On this islet were resting together the first of the spring migrants, newly arrived, and the last of the winter visitors, about to take their departure north. It was interesting to see the two speciessandwich terns and bar-tailed godwits-together, and from time to time the harsh cries of the terns were carried across against the wind. Near the terns were resting a flock of perhaps three dozen oyster-catchers, and distributed at various points along the island were eider drakes, with their mates beside them. Occasionally two drakes would have some trifling difference of opinion, and would grip each other by the nape of the neck, being urged on by their respective wives, who seemed to enter thoroughly into the sport of the thing. On the nearer island there sat and dozed many cormorants, immature, and so free as yet from the anxieties of approaching family cares.

By midday the wind dropped to the lightest of breezes; the sky remained clear, and in the strong sunlight many insects made their appearance, so that a swallow crossing the island on its northward flight found food in plenty awaiting him. Sandwich terns passed along the coast in twos and threes and in little bunches, plunging into the surf from time to time as their keen eyes spied some surface-feeding fry. In the air was the breath of spring and of summer soon to follow, and all the island seemed to revel in the quietness and sunlight after its long months of winter storms and biting winds straight from the bleak and sunless waters of the dour North Sea. 


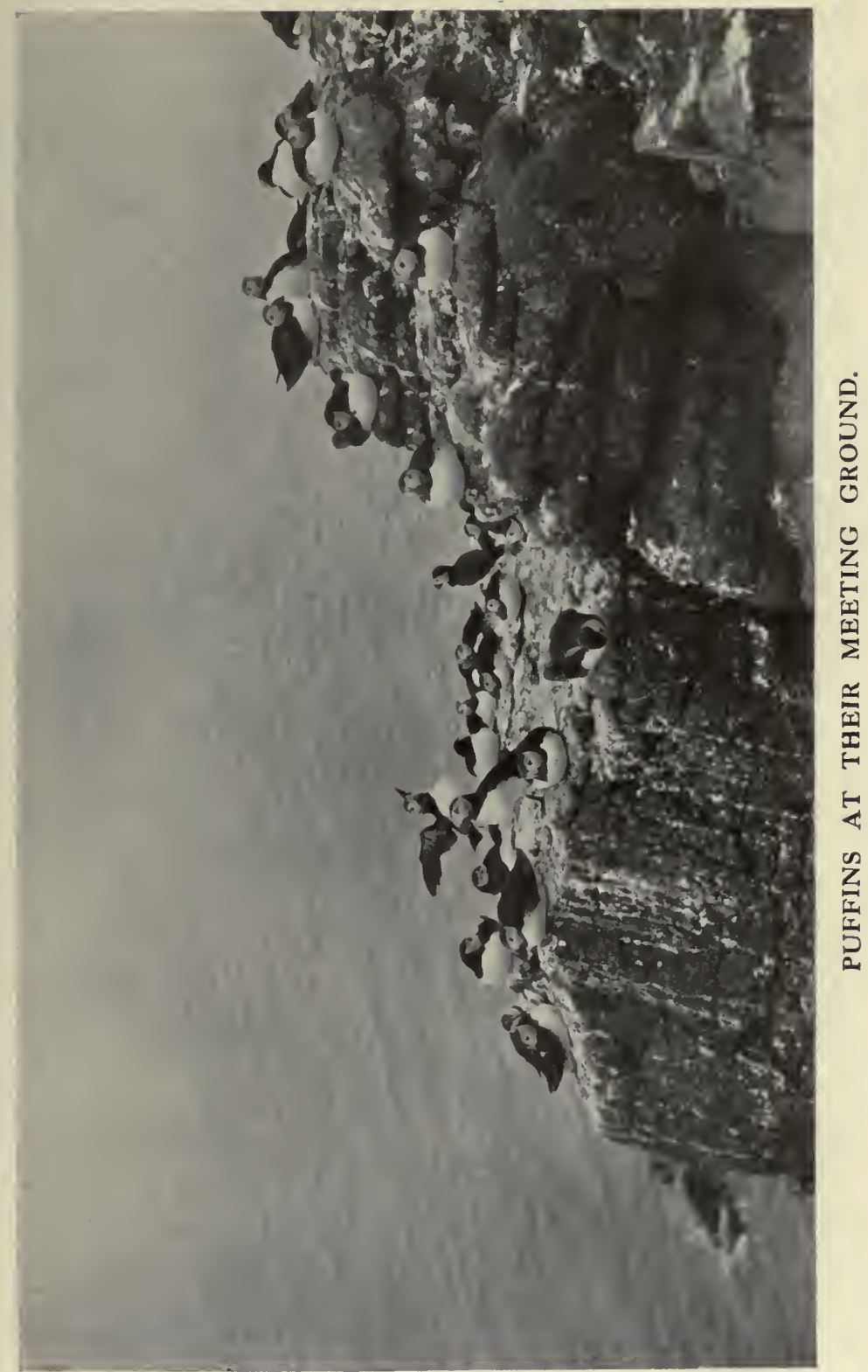






A Shag with her Full-grown Young.

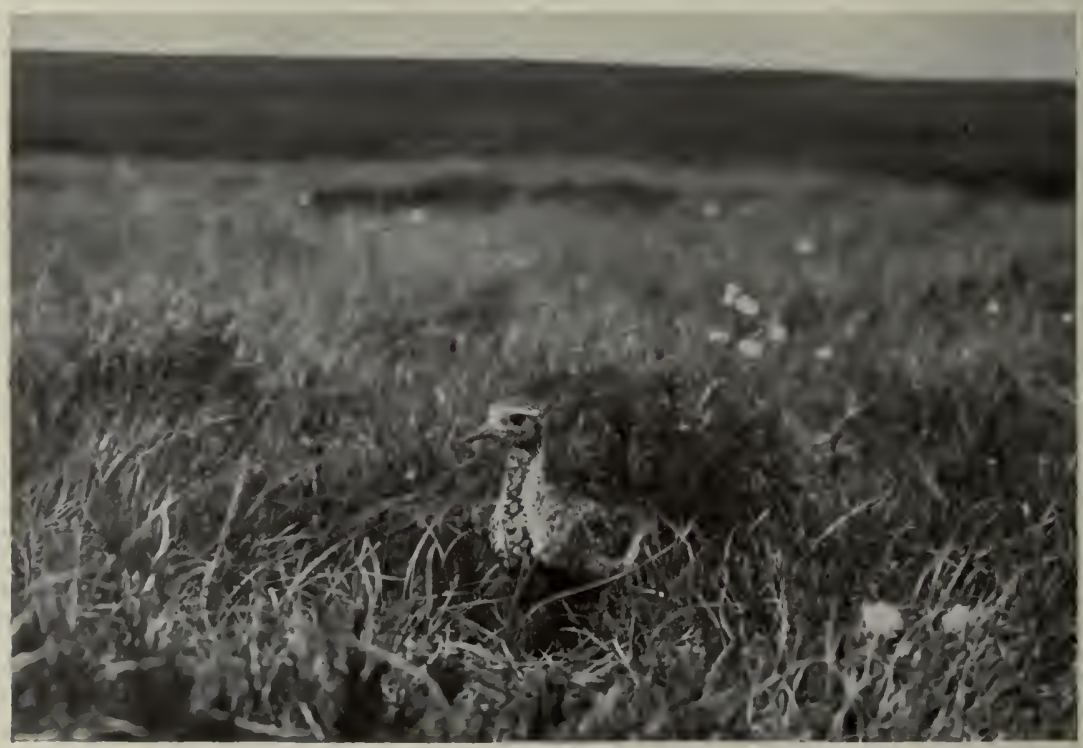

Golden Plover: A cautious Approach to Her Nest.

Note the bog cotton grass flowering round the nesting-site. 


\section{CHAPTER VI}

\section{THE GOLDEN PLOVER}

7 HE tides of February are come, bringing with them the breath of spring in the air. What little breeze there is blows softly from the south. The North Sea is calm and blue, and the swell breaks lazily on the long golden sands. A few miles out to sea lie the Farne Islands, each islet standing out clear in the sunlight. A little to the north of the main group is the bare rock known as the Megstone, where many cormorants nest. Through the glass they can be seen perched about the rock, their thoughts evidently turning, this fine day, to family matters. South'ard lie the Longstone, with its lighthouse; the Brownsman, the haunt of countless gulls and puffins throughout the summer; the Wamses, the home of the tribe of the sea swallows; and many other outlying rocks and islets. To the south of them all the long black rock known as the Crumstone just tops the water at the full of the tide. Away inland, and almost due west, Cheviot and its attendant hills stand on the horizon, still under the spell of frost and snow. Such is the winter home of the golden plover.

But with each spring-like day these birds become possessed with a great restlessness, for their thoughts turn to their spring haunts arnidst the hills, and before February is out many of them have left their winter quarters for the moors. To-day the plover are flying restlessly, at a considerable height and at a great speed. Their wing-beats are powerful and clean cut, the whole flock wheeling and swerving with remarkable precision. Passing overhead, their clear, tuneful whistle can be heard as they call to each other. 


\section{Wanderings of a Naturalist}

Flying this way, now that, the flock frequently makes as though to alight on some field, but they are nervous, and just as they appear about to settle, fly forward once more, ultimately alighting in a field of turnips a few hundred yards from the seashore, and at once commencing to feed. But they are not for long left in peace. Black-headed and common gulls appear mysteriously on the scene, and in the most innocent manner possible take up their stations near to the feeding plover, remaining motionless and apparently lost in thought. But should a golden plover within their keen range of vision be fortunate enough to secure some juicy worm, then the gull nearest to it is instantly galvanized into activity, and chivvies the unfortunate plover about until it is obliged to drop its find, which is at once devoured by the pursuer. As far as my observations go, this parasitic habit of preying on golden plover and lapwing is confined to our two smallest gulls, namely, the black-headed and common species (the former is the more notorious in this respect), for the larger gulls, such as the herring and black-backed varieties, never seem to obtain their food in this manner.

To the Northumbrian coast the golden plover is a winter visitor only, although those birds nesting in the high north still frequent the coast-line in flocks at a time when the British nesting birds of the species have long since arrived on the moors.

On the Cheviots and moors near them the golden plover nests in large numbers, but I do not think these birds winter on the Northumbrian coast. It is more probable that, at the close of the nesting season, the Cheviot nesting birds travel south, wintering in Ireland, or even south of the British Isles. As an instance of this south-westerly migration, a young golden plover, ringed as a nestling in Inverness-shire, was shot the same autumn in County Mayo. Thus the єvidence points to the birds one sees in winter being migrants from the north, perhaps Iceland and Norway.

It may, in this connexion, be of interest to mention that 26 


\section{The Golden Plover}

those golden plover nesting in the far north assume a more handsome and striking summer plumage than those breeding on the Border moors.

Although the golden plover winters along the coast, it is not a true shore bird. Only when hard frost binds the stubbles and renders its usual food inaccessible does it descend to the tide-mark. At such times flocks may be seen standing disconsolate on the rocks at low water-they very seldom alight on the sands-and at the first break up of the frost the birds return to the fields, showing that the food which they obtain between the tide-marks is less agreeable to them than that picked up on the cultivated land.

During a certain nesting season I had a golden plover's nest under observation almost daily. I discovered the nestsituated in a wild, inaccessible moorland bog in the Border country-on May 25, on which date the parent bird had been sitting, I judged, about five days. Returning to the bog the following morning, I started to dig a "hide" a few yards from the nest, cutting only a few sods to begin with, so as to avoid unduly alarming the bird. The making of the hide was continued on the 27 th, and after about two hours' hard work on the 28 th the structure was completed, and resembled a miniature covered-in grouse butt. I thereupon took up my station inside, with camera in position, and my companion, having walled me in carefully, left the nesting ground. Within the space of ten minutes the plover, quite unsuspecting, was back on her nest. The day was baking hot, with scarce a breath of wind, and the sitting bird seemed greatly distressed by the heat, panting constantly and looking most uncomfortable.

When I exposed a plate on her the slight noise of the shutter gave the bird a desperate start, and noticing for the first time the horrid-looking eye of the lens peering down on her, she shot off the nest, and had not put in an appearance again in two hours, at the end of which time I left the hide for the day. The following morning was cold, dull and misty, so I did not go to the nesting site; but the day 


\section{Wanderings of a Naturalist}

succeeding-May 30-was fine, and I was again left in the hide by my companion. The golden plover, as the result of her previous scare, was now highly suspicious, and showed no inclination to return to her eggs, so after a spell of waiting I went away. The following day I had better luck. I entered the hide at I0.55 a.m., and at II.7 the plover returned.

I succeeded in exposing a plate on her without causing her to leave the nest, but at II.40, when changing the plateholder, the slight noise I made frightened her off. At I2.IO she returned, very suspicious, but soon left again. As I gradually became familiar with the dim recesses of the hide I found that in one particular position I could see, through a chink between two sods, that part of the moor whither the golden plover went on leaving the nest. She generally stood quietly for a while in some short heather. Then, anxious for her eggs, she screwed up her courage and decided to return. A sheep track led close past the nest, and this she invariably used, running along it rapidly till she got near the nest, when she became extremely wary, and moved stealthily towards, and on to, her eggs. My hiding-place was not four feet from her, so I could clearly see the wild look in her large and beautiful eyes as she brooded on her nest. Her hearing was wonderfully acute. On one occasion on lifting my lunch from a piece of paper on which it rested, the faintest of sounds resulted, which, however, the plover was quick to hear, for she hurriedly left the nest and did not return for fifteen minutes.

I was able to see that she had comparatively little dark colouring on her breast, much less than one finds on the more northerly breeding birds of the same species. Curiously enough the cock bird never put in an appearance near the nest, although I frequently saw him on the hillside five or six hundred yards away. I was in the hide almost daily till June 12, on which date I visited the nest for the last time. On this day three out of the four eggs were commencing to chip, the youngsters cheeping inside the r prisons. 


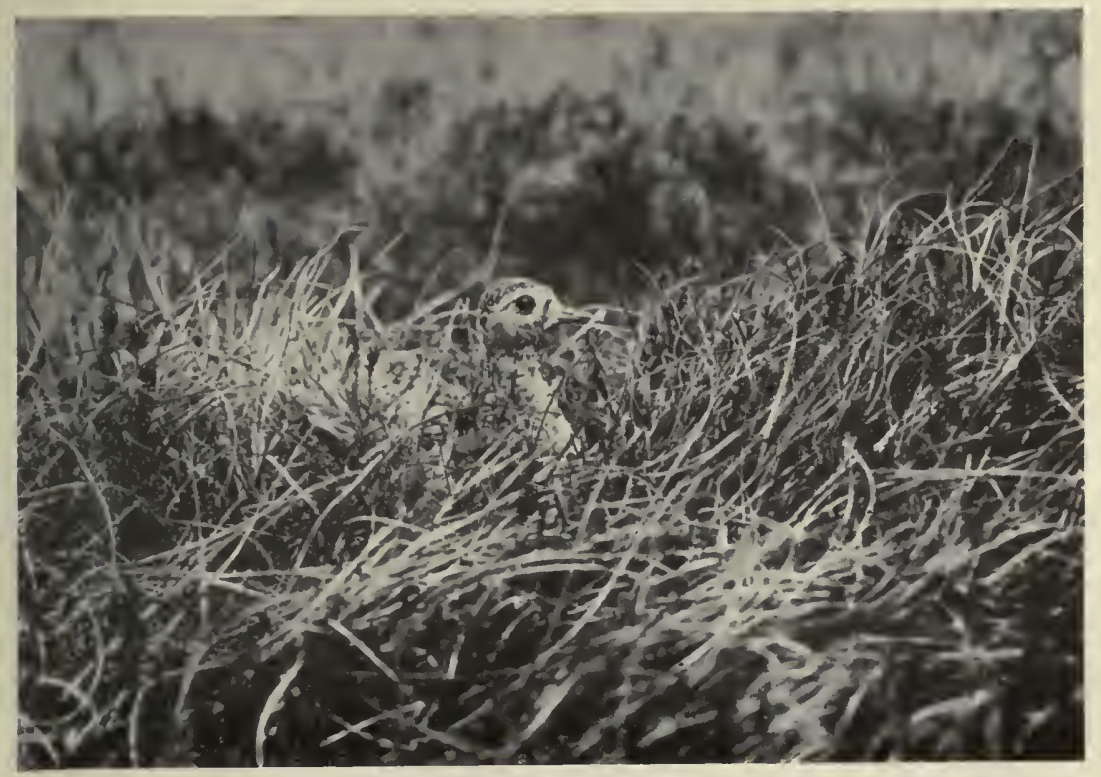

Golden Plover: On the Alert.



Golden Plover; Panting in the Heat. 




A Deer Forest in June.



The Northern Slopes of the Cairngorms under Snow in June. 


\section{The Golden Plover}

I had thus had the nest under observation for nineteen days. On being hatched, the young plovers run actively almost from their first hour, and are tended carefully by both parent birds.

In the early days of July Cheviot, up to the summit plateau, resounds with the wild melodious cries of countless golden plover tending their young in various stages of growth. By August the majority have left the hills, but stragglers are still on the moors at a much later date, and flocks of new-comers may be found right through the autumn, halting for a while on the high moors on their journey from the north to their winter quarters on the coast. 


\section{CHAPTER VII}

\section{A DEER FOREST IN JUNE}

$\mathbf{I}^{\mathrm{N}}$

$\mathrm{N}$ a deer forest bird life is more plentiful and varied than on a grouse moor. That arch egg-stealer, the grey crow, is permitted to rear his family in peace, and the swiftflying peregrine and lordly eagle hold undisputed sway among the corries where the mists swerve and eddy. Perhaps the best month of all the year in the forest is June. By then the birches, always late of coming into leaf, are in all the beauty of their first delicate greenness. By then, too, the blaeberries-the whortleberries of the south-carpet the hillsides with fresh young leaves and blossoms of dusky reddishbrown. On the sun-baked slopes the flowers of the cowberry - known in the Highlands as the cranberry - cluster, some white as snow, others tinged with pink, and in damp hollows many ferns grow rapidly. By the loch-side much bird life gathers of a still June evening. The greenshank, most wary of waders, is there with her young brood. All through May she was brooding her four beautiful pear-shaped eggs, concealed amongst prostrate pine branches near the loch; and now, with June, her downy youngsters are her pride. Most active of chicks are the young greenshanks, and they conceal themselves with remarkable skill.

During the months of summer sandpipers haunt the loch. They arrive some weeks later at their nesting quarters than the greenshank, and it is not until mid-June or even later that their young see the light of day. As the greenshank is wild and wary, so is the sandpiper confiding, and one can see them at their courting by the loch-side any day of May or early June. With quickly repeated, shrill, whistling cries the 


\section{A Deer Forest in June}

cock bird flies out with fast-moving wings over the loch, describing a wide circle time and again over the spot where his mate stands quietly on some stone at the water's edge.

Many goosanders haunt the lochs of the forest. Of a June evening one may see the drakes, handsome in their plumage of black and white, standing on the shingle, where the burn empties itself into the loch. The birds are in a comfortable frame of mind, for they have dined on the pick of the loch's trout, and are resting after their meal. At his fishing the goosander is an expert. The birds often fish in a body. They seem to drive the trout ahead of them, advancing across the loch in line-now flying on the surface with much scattering of spray, now diving and yet progressing with almost incredible speed. Time and again one may be seen to emerge holding in his bill a good-sized trout, which is rapidly swallowed. By June the young goosanders are several weeks old, and though as yet unable to fly, can swim and dive with great agility.

No deer forest would be complete without its pair of golden eagles, and in most forests this fine bird is strictly preserved. In June the eaglets are well grown, for the eagle is an early nester, and hatches off her brood by the first days of May. A favourite nesting site for the eagle is some weather-beaten pine standing far up the glen with a wide outlook. In the more western deer forests trees are few and far between, and eagles nest on ledges of rock; but such situations are apt to catch the drifting snow of an April snowfall, while on a tree, however exposed, the eagle runs no such risk.

On the high tops of the forest few birds make their home. The dotterel-one must not confuse it with the comparatively common ringed dotterel or plover-seeks the highest hill-tops, where, during June, the hen deposits her three richly speckled eggs in a slight hollow scraped amongst the as yet lifeless grasses.

On the shores of a small hill lochan that lies over 


\section{Wanderings of a Naturalist}

3,500 feet above sea level a pair of dotterel had taken up their quarters this June of which I write. All around this lochan ptarmigan croak of a fine sunny day, and the snowbunting twitters from the "scree" hard by or rises into the air after the manner of a tree pipit. No trout are in the lochan. It is too high for them, and is frozen across from October until the early days of June.

During fine evenings of June from various parts of the forest may be heard curious bubbling cries. They commence after sunset, by ten o'clock have ceased, but at dawn are recomrenced. These are the battle calls of the blackcock, and come from the gathering ground of the clan, where, with each dawn and to a lesser extent each evening, all the male birds within a considerable radius assemble to fight and "spar."

Another bird cry which is heard at dawn is the trilling of the melancholy curlew, that bird of the restless spirit whose call in olden time was heard with superstition and dread.

But during the season of which I write, the freshness and calm of June was broken into tragically by a great forest fire. Its origin was mysterious, but, fanned by a fierce wind after weeks of drought, the flames shot forward with incredible speed, consuming heather, bushes, and even stately pines in their path. And with their passing, gone were the young broods of the birds that nest in the forest. The birds, great and small, seemed to be fascinated by the fire, and were unable to escape, though a pair of crested tits showed remarkable wisdom, for they shepherded their newly fledged brood from tree to tree until they were out of the track of the flames. Before the fire the forest was a thing of beauty, pulsating with youthful life. At its passing it was a land desolate and charred, wherein no living thing stirred. 


\section{CHAPTER VIII}

\section{THE NESTING OF THE MERLIN}

TAC KING as he does the tremendous wing power of the peregrine or the stealthy, silent flight of the sparrow hawk, the merlin has a grace and charm on the wing which is unsurpassed by any of his tribe. I have often remarked on the resemblance of this flight to that of the swift; there is the same rapid motion of the wings, the same turning and wheeling in the air, the same joy of motion and of art perfected.

One season on a certain wide moor in the North of England I had reason to believe that a pair of these birds were nesting, but the way in which I actually found the nest was not a little curious. While sitting on a prominent mound I noticed a small company of rooks winging their way past, about a quarter of a mile distant. Then I became aware of a smaller bird flying after the rooks and rapidly overhauling them. Having seen the trespassers off his beat, the pursuer turned, and I marked him down over a ridge more than half a mile from me.

Crossing the moor, a few minutes' walk brought me to the spot, and sure enough a cock merlin rose from the hillside, carrying what appeared to be a small bird in his claws.

His behaviour was interesting. Apparently ignoring my presence, he flew steadily away until lost to sight, so that I was inclined to doubt whether he really had a nest near. But very soon he returned, having deposited his prey somewhere, and now circled round, calling anxiously. Some patches of old heather, such as merlins love as a nesting site, were near, and after a careful search I was very glad to see 


\section{Wanderings of a Naturalist}

the hen bird rise from her nest not three yards from me. She flew away in silence, moving low and just skimming the tops of the heather plants.

In the nest were three newly-hatched young and a piece of egg-shell. To all appearance the youngsters were, at the outside, but three days old, having probably hatched out on June 12. Clad in thick coats of white down, they had a pinkish tinge on them. Both parent birds showed great anxiety, circling round and calling repeatedly, their cries being not unlike those of the peregrine, though less powerful.

At times they alighted on the moor, choosing a ridge from where they had the nesting site under observation. The nest was well protected by long heather, and was invisible till one was standing almost over it. I was interested to see the remains of what was probably the nest of the previous year, only about a foot distant, and practically joined to the nest in use.

Curlew, golden plover and grouse were all nesting in the vicinity, and seemed quite undisturbed by the circling of the hawks.

On June 2 I I again visited the nest. A strong breeze of west wind swept the uplands, driving white clouds before it. In the alternating sun and shade the moors were at their best, and many miles of hill-country extended as far as the eye could reach. Curlew and golden plover were here in plenty, the trembling cry of the whaup mingling with the pipe of the plover. Most of their broods had hatched off ere this, but one curlew was still brooding her four large pear-shaped eggs as I passed. Very agitated she was, and did a thing which I have never known a self-respecting curlew do-alighted on the post of a fence redshank-wise, and in this unusual position repeated without ceasing her alarm cry.

Although only six days had elapsed since my last visit to the young merlins, there was now a great change in their appearance. Their white down had taken on a greyish tinge, and already their tail feathers were beginning to sprout. No 


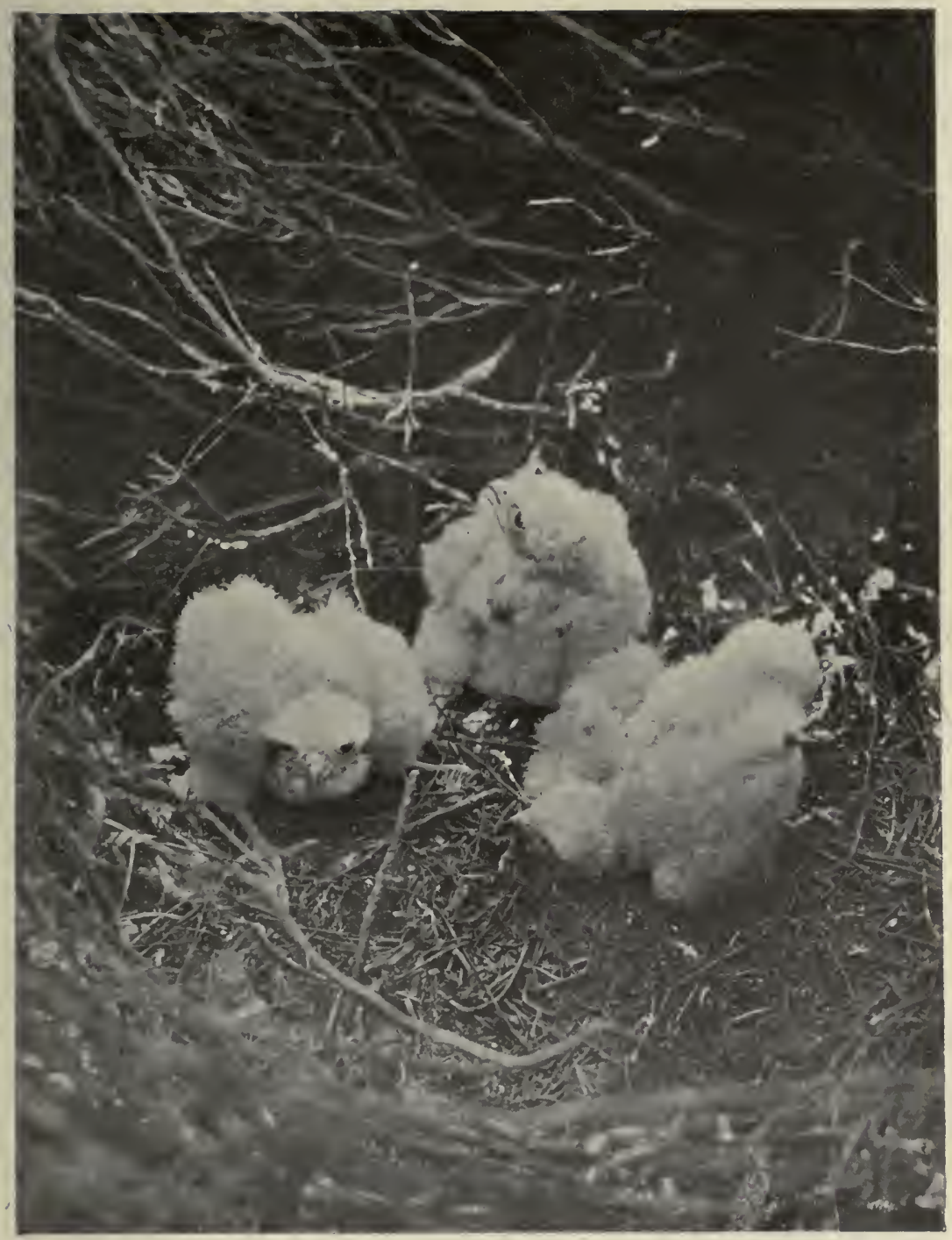

YOUNG MERLINS. 




YOUNG MERLINS: FEATHERS JUST BEGINNING TO SHOW. 


\section{The Nesting of the Merlin}

prey was at the nest; indeed, during all my visits I never saw signs of any, so I imagine the parents were none too lavish with their supplies. It is possible they may have had a "larder" in the neighbourhood, where they kept their "kills" until actually needed. A few castings of the young birds lay in the nest, otherwise it was clean and tidy.

In the strong breeze the grace and power of the merlin's flight was seen at its best. Flying lightly and easily, the birds moved rapidly backwards and forwards, little affected by the wind.

On June 28 I made an early start for the merlin's nest. A thick frosty mist covered the lower grounds, and there was a nip in the air associated more with an April than a June morning. Passing an upland farm tenanted by fully a dozen pairs of swifts, not a sign was to be seen of these birds, for in the frosty air insect life was non-existent, so the swifts were enjoying some hours of extra sleep!

The morning sun was shining bright and warm before the merlins' nest was reached, and, as usual, the parent birds called anxiously and often.

The wing feathers of the young merlins had by now appeared and were growing quickly, but much down still covered them. I noticed how the down of the throat was markedly lighter in colour than that on the other parts of the body. Their legs were bright yellow, and their talons well developed. They now strongly resented being handled, turning over and striking upwards angrily with their feet, as is shown in one of the photographs. Circumstances prevented my visiting the young merlins again till July 15. I had hoped to find them still in the nest, but was disappointed, and from the behaviour of the parent birds, I surmised the young were at a part of the moor some 250 yards from the vicinity of the nest, but I did not actually see them.

An interesting point about the now deserted nest was that it did not contain a single bone of any of the merlins' victims. Now, the peregrine's eyrie has, usually, bones in such 


\section{Wanderings of a Naturalist}

numbers that even in the following season they are the most conspicuous part of the nest, and the eggs are laid on them. Another thing worthy of note was that a well-worn path through the heather extended from the nest quite three yards, this seemingly pointing to the fact that when alighting with prey the parent birds did not fly straight to the nest, but walked from a little distance for better concealment.

The young merlins, I should say, must have left the nest at least three days previous to my visit. That would fix the date of their departure as July 12, but it was quite possibly earlier; so it would seem that young merlins do not remain in the nest for a longer period than four weeks.

On July 27 I paid a last visit to their nesting ground. The moorlands were now becoming strangely quiet. Out of perhaps two dozen pairs of nesting curlews, only a solitary bird remained to utter her melancholy alarm note-all the rest had reared their broods and had taken their departure for the sea-coast in more southerly latitudes. Two pairs of golden plover still guarded their young, but most of these birds, too, had left, and meadow pipits no longer called in their own cheery way; they had reared their second broods and had lapsed into silence. The young merlins were no longer in the vicinity. Under the guidance of their parents they were ranging the moorlands and being initiated into the mysteries of their craft, and I could but wish them well and that they might escape the keeper's gun. As I left the nesting ground the sky clouded, and soon a steady rain commenced to fall, wrapping the moors in its haze, and bringing renewed life to grass and heather, parched by weeks of drought and of summer's sun. 


\section{CHAPTER IX}

\section{BRAERIACH IN MIDSUMMER}

$\mathbf{A}^{\mathrm{r}}$

FTER the prolonged heat and drought of a recent May, the month of June brought to the central Highlands unusually cold and boisterous weather, with much heavy rain in the glens and snow on the tops.

On the morning of June $26 \mathrm{I}$ made the ascent of Braeriach from Loch Einich, a remote loch lying nearly I, 700 feet above sea level, and found conditions more resembling mid-winter than the longest days of the year. The Bennaidh, issuing from Loch Einich, was rushing in semi-spate under the now long-discarded sluices which were used in former times to dam back the loch in order that the timber from Rothiemurchus and the surrounding forests might be carried down to the sea in an artificial spate. At the end of the loch many burns were rushing down dark Coire Odhar, the largest of them having its birthplace in Loch nan Cnapan, on the Moine Mhor. Sgoran Dubh, near its summit, was powdered with snow, which covered the young green of the blaeberry shoots and the black rocks in a uniform garb of greyish white.

Within two hundred yards of the upper bothy of Glen Einich a deep bed of winter's snow still lingered, but as a whole the hills were exceptionally free of old snow for so early in the summer. A bitter wind blew up the glen from the north, as, following the stalking path which winds up the shoulder of the hill past Coire Dhondail until it emerges on that wild plateau known as the Moine Mhor, or Great Moss, I came upon the fresh snow at an elevation of 3,000 feet. At first it lay in small patches, but gradually became continuous. The severity of the previous night's frost 


\section{Wanderings of a Naturalist}

could be judged by the fact that large icicles hung from the rocks on which a cluster of globe flowers were bravely holding their blooms to the icy wind-an extraordinary contrast for late June. From some boulders a hen ptarmigan emerged, reluctantly leaving her brood, which she had taken from the grass to the rocks for more shelter and warmth.

Just before emerging on the plateau one crosses a small burn having its source on the summit plateau of Braeriach. To-day this burn, swollen as the result of the recent rains, presented a wonderful spectacle. The strong wind had blown the water over the surrounding stones, and the frost had frozen this spray, so that each boulder was encrusted in a sheet of transparent ice. Each blade of grass fringing the burn also bore this icy covering, so that it was many times magnified in size and sparkled in the light. A few days before the storm the plateau had been gay with many plants of the cushion pink, in all the glory of their flowering. To-day the blooms presented a sorry sight, for they had been destroyed almost beyond recognition by the polar wind. Even the grass had lost some of its greenness-and the grass on the high grounds was unusually good that season.

At a height of perhaps 3,500 feet I came across a hen ptarmigan covering two chicks on a small snow-free patch, and moved on as quickly as possible in order that the mother might return before the cold had numbed the young. A little farther on a ptarmigan's nest, from which the young had been hatched, just showed through the snowy surroundings.

As I reached the summit plateau of Braeriach, a few hundred yards from the Wells of Dee, the scene was a truly polar one. Mist clouds hurried southwards, just touching the plateau, and everywhere was snow and ice. The Wells of Dee were half-covered with snow and in places drifts lay two feet in depth. On the extreme summit of the hill-about a mile to the east-mist still lingered, and across the dark rocks of the Garbh Choire, Ben MacDhui could be seen, its summit also powdered with white. Owing to the fact that the 


\section{Braeriach in Midsummer}

storm had come from the north, Cairn Toul had escaped lightly, and no snow lay even on its highest slopes.

Shortly after midday the most sudden change that I have ever seen on the hills transformed the whole face of the country from Ben MacDhui to the far distant Atlantic. As though by magic the mist everywhere lifted, and from a sky of deep blue the sun shone brilliantly. Near the head of Horseman's Corrie I lay awhile, sheltered from the wind. Westwards countless hills formed the horizon. Ben Lawers, above Loch Tay, was plain, and the cone of Ben More above Crianlarich. Even the snow-beds on Ben Nevis were clear, and I imagined I could see the sharp peak of Ben Cruachan sloping away to Loch Awe. Then to the west of far-distant Ben Nevis I could make out what I think were the high hills about Kingairloch, or even the Island of Mull itself. It has been asserted that from Braeriach the Cuchulain Hills in Skye can be made out. I do not think this is the case, but the sharp hills which lie about Knoydart may have been mistaken for them.

In Horseman's Corrie the drifts of fresh snow were extensive and blotted out the large field of winter's snow which I had seen there earlier in the week. The air, out of the wind, was now quite warm, and the blaeberry plants were giving off their fine scent about me. Several ptarmigan rose from their broods, and an indication of the severe weather was given by the fact that in two instances but a single chick survived, while in another-and I think this bird was the same as the one I had flushed five days previously with a brood of six-only two now remained. By evening, except for a few wreaths, the snow had entirely gone, and every hill burn was running fast and full. Thus came and vanished a storm of midsummer snow, and one hoped that a spell of fine and windless weather might now come to the high grounds for the sake of the deer and the mountain birds, whose existence, even under favourable circumstances, is a hard and almost incessant struggle against the elements. 


\section{CHAPTER $\mathrm{X}$}

\section{A NESTING HAUNT OF THE SCOTER}

THE longest day of the year found me at a wind-swept Irish lough, where for the past few seasons a number of scoter ducks have nested.

It was in 1903, I believe, that the first pair of scoters appeared on this lough. Since then their numbers have increased, until there were, at the time of my visit, at least seventeen pairs nesting. That particular year they made their first appearance there about April ro. At this time the drakes are resplendent in their black, glossy plumage, and as they "display" before the ducks their loud, whistling cries may be heard at a great distance. Of all the ducks on this lough the scoter is probably the latest to nest, and lays her eggs even after the red-breasted merganser or the tufted duck. Immediately the scoter duck commences to brood the drakes disappear from the lough and probably seek the Atlantic lying some twenty miles to the west. Certainly they are not again seen on the lough until the following spring. In like manner the young vanish mysteriously soon after they are hatched, although on one occasion a "flapper" was shot early in August.

Arriving at the small station on the lough-side, I found a boat awaiting me, and the veteran watcher, who had the birds under his charge, informed me that he knew of two scoters' nests on islands lying a mile or more up the lough. Unfortunately the weather resembled October rather than June. A westerly gale swept in from the Atlantic, bringing with it driving squalls of misty rain and causing a heavy "sea" on the lough. Fortunately the wind was aft, but this notwith- 


\section{A Nesting Haunt of the Scoter}

standing, the veteran at the oars was hard put to it to keep the boat stern to wind.

There was no rowing to be done, for the gale carried us forward rapidly and we soon shot past the first island and pulled the boat into the sheltered water on the leeward side. In doing so we caused consternation amongst several tufted ducks sheltering here with their broods, the mothers scattering and the little fellows swimming out into the rough waters, all except one brood, which sensibly remained dodging about under the shelter of the island.

As we landed sandpipers called anxiously in their sharp, whistling cry, and a tufted duck rose from her nest at our feet. The watcher led the way to where he said was a scoter's nest, but when at length, after much searching in the thick undergrowth, this was found, the duck was off and the eggs were carefully covered with down, which seemed to me remarkably like that of a tufted duck. The watcher, however, assured me that he had actually seen a scoter rise from this nest, but I was disappointed not to see the bird for myself. However, the second island lay near, and to this we now made our way. Just before we shoved off I saw a lesser black-backed gull flying in a suspicious manner over the wild waters of the lough near where, I felt sure, some of the young tufted ducks must be struggling with the waves.

At length the gull swooped down and rose from the water's surface with a young tufted duck in his beak. Several times the gull tried vainly to swallow its victim, till at last the unfortunate duckling disappeared down the murderer's capacious throat. I was told that on this lough many enemies lie in wait for young ducks. Both greater and lesser blackbacked gulls search the waters assiduously for any young broods, and in the peaty depths are large pike which suck down their small victims.

The second island which we visited was considerably larger than the first, so that there was more chance of our landing unheard and unobserved by the birds nesting there. 


\section{Wanderings of a Naturalist}

The grass, interspersed with clumps of the sweet-smelling bog myrtlc-that fragrant plant of the west-grew high round the sheltered bay.

All vegetation had suffered from a severe gale of northwest wind on June 9-a gale almost without precedent for the season of the year-and even the leaves of the birches were burnt red and the bog myrtle was stripped of its foliage. On this island reed buntings rose before us anxiously, and Arctic terns were nesting near the water's edge. Very cautiously we approached the clump of furze bushes where the scoter had her nest. The watcher had located the spot and was searching the undergrowth carefully when the scoter duck rose from her eggs, flying slowly up wind and giving us an excellent view of herself in her subdued brown plumage with a patch of greyish-white feathers on either cheek. She settled on the water near, constantly raising her neck-a peculiarity of the species-and half-rising in the water. The nest contained seven eggs of a rich cream colour, and there was little down present, so I imagine the eggs were fairly fresh. Indeed, the watcher informed me that he knew of one pair of scoters the duck of which had not yet commenced to brood. The scoter showed considerable anxiety for the safety of her eggs and several times flew round the island, reminding me of winter days on the north-east coast, where I have watched companies of these birds feeding off-shore and diving for hours on end at their fishing, or to avoid the heavy breakers churned up by a stiff north-easter.

The storm continued unabated till evening, when the wind veered north-west and fell somewhat, and woodcocks emerged from the birches fringing the lough to indulge in their customary evening flight. But before midnight the wind backed, and when morning came a westerly gale was again sweeping the lough, so that further search was impossible, and I amused myself by watching the ringed plovers and redshanks which had their broods near the house.

Not many miles from the nesting ground of the scoter is 


\section{A Nesting Haunt of the Scoter}

a solitary island lying far out in the lough, where a colony of sandwich terns breed, and although the Atlantic is fully twenty-five miles distant, the birds, I believe, do not fish in the lough, which is a fresh-water one, but regularly make the fifty-mile flight throughout the day, returning, apparently unwearied, with their catch of sand-eels.

I had hoped to visit this island also, but the weather rendered this impossible, and I had to rest content with having identified a nesting scoter on an Irish lough, where it is to be hoped the birds will remain undisturbed and increase their numbers. 


\section{CHAPTER XI}

\section{BEINN EOLOSARY OF ULVA}

TANDING westward of the Isle of Mull and divided from it by scarce a couple of hundred yards of sea is the wild and sparsely-populated Island of Ulva. The island is mouniainous throughout, and its two outstanding hills are Beinn Chreagach, 1,025 feet, and Beinn Eolosary, exactly I, 000 feet above sea level. While along the eastern coast of Scotland the summer of which I write was an abnormally dry one, the opposite was the case in the west, and during August and the first part of September fine days were the exception. So that when a morning opened with bright sunshine and clear blue sky, I decided to climb Beinn Eolosary for the fine view that is to be had from the top, and early left my base on the lesser and adjacent island of Gometra.

Buzzards sailed above me, uttering from time to time their high-pitched moaning cry. All of a sudden one of their number stooped to earth at express speed, but the bird was apparently at play, for I saw no rabbit or any other prey captured. It has always struck me as curious that the buzzard should call so frequently, as compared with the eagle. As I watched through the glass one of the buzzards was chased by a peregrine and alighted on a rocky pinnacle near me, his rich plumage showing clearly in the bright sunlight. A little farther along I disturbed a buzzard and a pair of ravens from some high basaltic cliffs fringing the Atlantic. The buzzard flew lazily off pursued by the ravens, and so hot did the pursuit become and so angrily did the ravens swoop that the buzzard was compelled to alight on some low rocks close to the sea. Thereupon one of the ravens flew off, but 


\section{Beinn Eolosary of Ulva}

the other was by no means satisfied, and also alighted, close by the buzzard, walking from side to side as though debating whether a frontal attack should be made. But at length, apparently arriving at the conclusion that the buzzard was too formidable a customer to be tackled singlehanded, the remaining raven took wing and the buzzard was left in peace.

The heather on the hill was, this early autumn morning, at its best. While on certain Aberdeenshire moors that season it was so burnt by the drought that no bloom was to be seen, on the western seaboard it never lacked moisture, and this day threw its scent far across the hillside. Right up to the summit cairn it was in bloom, and having reached this cairn I spied for some time one of the finest views I have ever enjoyed. Westward one looked across the adjoining island of Gometra-which is divided from Ulva by only a very narrow strip of water known as "the Bru"-to where a multitude of islands were set in the deep blue of the Atlantic. A few miles to the westward lay the picturesque group of the Treshnish Isles. Of these, Bac Mor and Bac Beag-or, to give them their more recent names, the "Big and Little Dutchman"-lie farthest out into the Atlantic, but through the glass one could, even at this distance, clearly make out the cattle feeding on their grassy slopes. Then, two miles to the northward from these ocean sentinels, the long green island of Lunga was reflected in the quiet waters, its terraced hill being also tenanted by many cattle. Next came the smaller islets of the Treshnish group : Sgeir a' Chaisteil, or the Castle Rock, with Sgeir an Fheoir (Grass Island), Fladda-where the lobster fishermen live during the season of summerand the two Carn a' Burg islands. It was on the larger of these two islands that Maclean of Duart had his stronghold in times now long past, and even from Beinn Eolosary the ruins of the fortifications could be seen. Far to the west of the Treshnish Islands lay the Island of Tiree, with its three hills-Beinn Hynish, Ceann a' Bharra, and Beinn Hough- 


\section{Wanderings of a Naturalist}

all showing clearly. Even the houses of Ballemartine and Scarinish could be identified, and the hotel at the latter village. To the south-west no land lay between me and Ireland, but, showing with wonderful clearness, the lighthouse of Skerryvore was dazzling white in the sunlight. Several trawlers were at work in the neighbourhood of Skerryvore, and not the slightest heave of the Atlantic waters disturbed them, for to-day no swell came in from the south-west, and only a faint northerly breeze ruffled the waters at certain places; at others the ocean lay mirror-like. Bearing more to the southward, many small islands a little off Ulva met the eye. On these islands terns nest, but these had already taken their departure, and the islands seemed deserted save for a flock of curlew which flew in from the sea. A mile or two beyond them, from the one and only house on the island of Little Colonsay, blue peat smoke was rising in the still air.

Some half a dozen miles into the Atlantic the grassy plateau of Staffa was emerald green after the recent heavy rains. Concerning the origin of this famous island, local tradition has it that Torquil MacLeod, a giant, was doing some work in the neighbourhood of the Giant's Causeway, in the north of Ireland, and decided to remove a piece of the Causeway to his home, which was in the neighbourhood of Eigg. So slinging a portion-Staffa-over his back he set out for home. Lying just off Staffa is a small, black rock, known, apparently ironically, as Staffa Mor, or Big Staffa, and it is said that this portion was the first to fall from Torquil's back. Frantically he strove to reach land with his burden, making for Gometra or Ulva, but, alas! the rope gave way and Staffa splashed into the sea! A quaint origin for one of the most famous islands in existence.

Some twelve miles south of the slopes of Beinn Eolosary, Iona lay in bright sunshine, its white sands shining brilliantly, and away behind the highest point of the islandDun I--could plainly be seen the dark rock of Dubh Hirteach, with the lighthouse surmounting it. During heavy weather 


\section{Beinn Eolosary of Ulva}

the seas break right over the summit of this lighthouse, and the whole building sways and trembles with the impact of the waves.

To the north-west, and lying many miles behind the rugged island of Coll, hill upon hill of the Outer Hebrides stood out sharply against the horizon. On the most southerly of these islands-Barra Head-the lighthouse, even at this distance, could be made out. Then, bearing north, were Hecla above Castlebay, and Ben Mor of South Uist, while, its summit just appearing above the sea, Eaval of North Uist showed faintly. Nearer at hand, but in a direct line with the latter, stood the lonely lighthouse of Heiskeir, where, until recently, grey seals had their home. Almost due north many islands showed : low-lying Canna, mountainous Rhum, with Eigg and Muck nearer at hand. Behind these again the Cuchulain Hills of Skye caught the sun's rays. More to the eastward lay the hills of Knoydart, and amongst the many peaks in that direction Ben Nevis was the only hill on which a cloud rested. But one had not to look far afield for fine scenery, for the neighbouring island of Mull supplied that to the full. On either side of Beinn Eolosary the two sea lochs_Loch Tuadh and Loch nan Ceall-cut deeply into the hill country. At the head of the latter loch Ben Mor rose straight from the sea waters, the wide corrie known as Coire Ghorm and the great precipices north-east of the summit cairn seeming but a stone's throw away. Still nearer were the dark rocks above Gribun, where the grass was already browned as the result of many cold winds from the north-west which that summer had brought to the west coast. The bracken also, wherever exposed to the wind, was standing brown and withered, in which condition it had indeed been since the latter part of June.

Gradually, as the day advanced, a rainbow ring encircled the sun, and thin clouds spread over the sky from the south; but even after sunset the sky in the north retained its deep blue, and hill and island stood out with exceptional clearness. 


\section{CHAPTER XII}

\section{THE NESTING OF THE RITTIWAKE}

$\mathrm{O}$ F all our sea birds the kittiwake is-with the exception of the storm petrel-the last to commence nesting operations. On May 16, the date of my first visit to a kittiwakes' island, the birds had commenced to repair their old nests, or build new ones, but there was not an egg to be seen anywhere, though the razorbills and guillemots had already started to lay. By the 28th none of the kittiwakes nesting on the east-facing rocks had laid, whereas those birds inhabiting the north-east cliffs had, in almost every case, commenced to brood, although one would have thought the birds would have been later on this sunless nesting ground. By June 15 almost all the kittiwakes on the island had eggs, but I saw at least one nest not yet finished.

In their behaviour on their nests the kittiwakes varied greatly. Some birds were very nervous, not venturing to settle down on their eggs while I was near, whereas others brooded so close that I could approach them to within a few yards. I have never known kittiwakes to nest in such easily accessible rocks as on this island of the Irish Sea. In some cases a child could have taken the eggs without difficulty, and with care many of the sitting birds could be approached within easy photographing distance.

On July 16 all the kittiwakes had hatched off their young, with the exception of one bird, which was brooding a solitary egg, and continued this thankless task-the egg was addled -until into August, and the bird whose nest was not completed on June 15. This latter nest, on' July 20, contained one egg and one young bird, but shortly afterwards some 







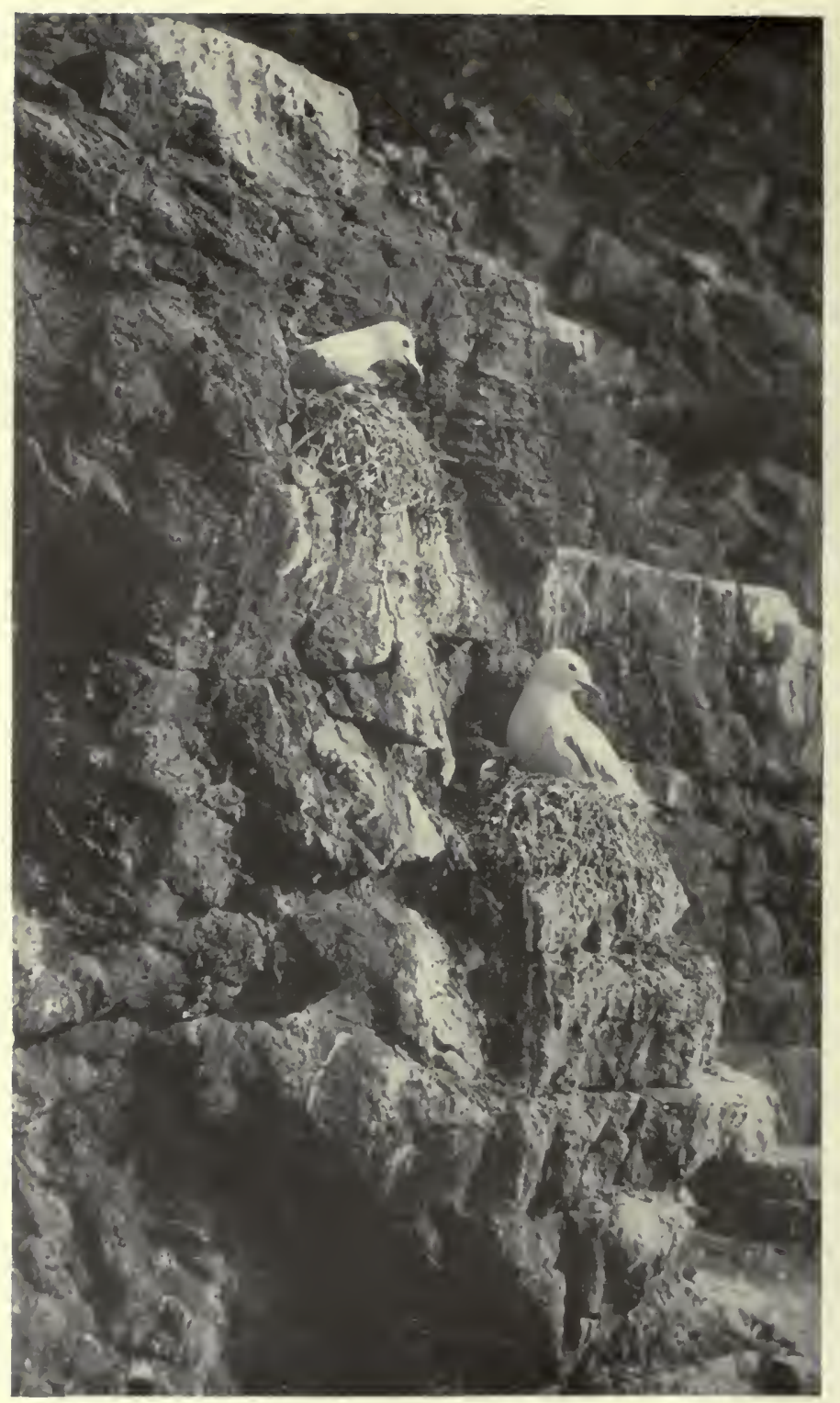

KITTIWAKES : ATTENTIVE SIT'TERS. 


\section{The Nesting of the Kittiwake}

mischance must have happened to the latter, for it disappeared.

While at the nesting ground I unwittingly disturbed two young shags which wandered to a kittiwake's nest containing two young birds. Periodically the mother kittiwake, strongly resenting the intrusion, would settle on the ledge and grab one of the young shags furiously with her bill. The latter paid not the slightest notice, showing no resentment for what was probably an almost everyday chastisement in a nesting ground where the quarters are so crowded.

When flying from their nests I noticed the kittiwakes usually uttered a long wailing note somewhat resembling the word " $p \bar{e}-00$ "; at other times, when flying around in agitation, they used a high note, "hoch, hoch" ; also a sharp call something like "kik, kik, kik." When what I imagined to be the cock bird alighted on the edge of the nest, where the hen was already standing, he became most excited, shrieking out, "kittiwake, kittiwake, kittiwake," and ending up by "kik, kik, kik." This effort seemed to require considerable exertion, and the bird appeared to swallow hard when it was over, as though something had stuck in his throat.

On July 28, when I again visited the island, most of the young kittiwakes were well feathered; indeed, I think that some had already left the nests, for when I approached their nesting rock a number of the young birds flew out to sea quite strongly, as though this was not their first flight. There was one young kittiwake, however, which had evidently been hatched very late, as it was still in down.

While watching one of the parent kittiwakes at the nest, I made the following notes on the adult's plumage, observed from very close quarters: Bill, greenish yellow; legs and feet, black. At either side of the bill, at the base, a small patch of dark red. This patch, however, seemed to be almost absent in some of the birds I had under observation. Irides, red. A fully-grown young kittiwake near had the bill black, 


\section{Wanderings of a Naturalist}

and a collar of greyish black, which did not, however, extend all the way round the neck. Round each eye a patch of greyish black.

By August 13, a fine, sunny day, almost all the young kittiwakes were strong on the wing, but the late-hatched chick to which I have referred still had some down adhering to it. I think that by this time some of the kittiwakes had left the island,- but as yet there was no appreciable decrease in their numbers. On August $3 \mathbf{I}$ the solitary young kittiwake had not even then left the nest, though it seemed ready to do so. By this date nearly the whole kittiwake population had departed, and the rocks seemed strangely quiet and deserted. There is probably no bird so devoted to its nest as the kittiwake, and even now, when autumn had arrived, I saw some of the birds still brooding on their empty nests. On September 8, the last time I visited the island to study the life of its sea birds, out of the thousands of kittiwakes nesting on the cliffs, only two birds remained at their nests, and the only young birds on the island were a nestful of young shags.

About this time many young kittiwakes were to be seen on a minute rocky island about fifteen miles south of that on which they were reared, but before the end of September they had moved south and would not return again till the spring. 


\section{CHAPTER XIII}

\section{CAIRNGORM AND BEN MACDHUI : A DAY ON THE HIGH TOPS}

1HE early months of that season, while bringing to the low country a mild and early spring, had clothed the

1 Cairngorm hills with snow to an even greater extent than usual. Even with May there came no break in the wintry conditions, and up to the 23 rd of that month the high plateaux were spotlessly white. Indeed, a stalker with more than twenty years' experience of these hills told me that he had never seen the Cairngorms carry such a depth of snow so late in the season. May 23 was sunny and mild, with a strong breeze of south-west wind. That evening the breeze fell away, and scarce a breath of air stirred the next morning as I left Glenmore Lodge, near the shores of Loch Mhorlich, for the summit of Cairngorm. The western Cairngorms that spring carried much more snow than those hills of the same range lying farther to the east. Indeed, round the summit of Cairngorm itself little snow remained, though fringing Coire Chais was the usual extensive semicircular drift. But to the westward the Snowy Corrie, or Coire an t-sneachda, as it is known in Gaelic, was still filled almost entirely with snow, and Coire an Lochan near it wore a mid-winter aspect.

From Glenmore Lodge the track, after crossing some boggy pasture land, where curlew trilled this morning of late May and oyster-catchers piped, enters the pine forest and emerges on the shoulder of Cairngorm. The first ptarmigan were seen before the 2,500-foot contour line was reached. By their anxious behaviour the cocks we passed showed they had sitting mates near, for they refused to fly far, and stood perched on prominent boulders looking anxiously around. 


\section{Wanderings of a Naturalist}

But it was only the lowest nesting ptarmigan that had begun to brood as yet. Even at 3,000 feet the birds-and ptarmigan were very plentiful on Cairngorm this still and sunny morning -were still going in pairs, and throughout the whole of the day, during a walk over many miles of ptarmigan country, I came across no nesting birds until on the slopes of Creag na Leacainn, under 3,000 feet, late in the afternoon. Just below the summit of Cairngorm were several pairs of ptarmigan together, sheltering from the strong south-east wind which swept the summit, and enjoying the warm sunshine. The summit cairn was reached shortly after midday, and from it a wild scene of Arctic character extended. From Cairngorm to the rounded summit of Ben MacDhui there stretches a great plateau, which to-day was almost entirely covered with enormous fields of snow. Beyond the plateau the upper slopes of Cairn Toul and Braeriach rose up, spotlessly white, and with great cornices, in which rents and cracks were appearing as a result of the rapid melting of the snows fringing the summits.

Though the sun shone warm, a thick haze blotted out any distant view, but soon the wind shifted from south-east to a point or two west of south, the haze cleared away to a considerable extent, and the sun shone forth with great heat from a cloudless sky. Each burn on the plateau was flowing for almost the entire length of its course beneath the snow, and one could thus cross the streamlets anywhere on these snow bridges. Not a vestige of growth as yet was stirring amongst the hill plants. The creeping azalea, which should, before the first days of June, be showing its beautiful crimson flowers in profusion, was as browned and withered as in December, and the clumps of cushion pink were dried and apparently lifeless. It was curious, on such a day of summer warmth, to find the plateau still as in midwinter, and difficult to realize that only a day or two previously the first breath of spring had not penetrated thus far.

On the snowfields were the roosting-hollows of ptarmigan 


\section{A Day on the High Tops}

-some of them quite freshly excavated-and on one of these snowfields I found an oak leaf lying. It had evidently been carried up thither from Speyside, or maybe from the valley of the Dee, but anyhow, a distance of many miles, by a furious winter's gale when the surface of the snow was hard and dry.

Despite the Arctic conditions of the plateau, insect life was fast awakening under the sunshine. Humble bees flew strongly hither and thither, searching perhaps for honey from non-existent flowers, and spiders crawled near the snow.

Just beyond the deep hollow where lay Loch Avon, Beinn Mheadhon, with its stone-studded top, carried little snow, but to the westward of that hill, Loch Etchachan, in Mar, was still frozen half across, with a strong breeze ruffling the liberated waters. An eagle crossed the plateau near me, making as though for the great precipices in the neighbourhood of the Shelter Stone, where was, and probably still is, an eyrie of these fine birds. Flying against the breeze, and speeding past me like an arrow, a dotterel winged its way south, having apparently just come up from the low country:

It was curious, as one crossed a snowfield, to feel the instant lowering of the temperature. The glare from the snow was dazzling, so that, arriving at the bare dark ground beyond, one seemed to enter a region of twilight, so great was the sudden transition. Each burn, where it could be seen, was running full and clear-for snow water is never coloured. The streamlet known as the Feith Bhuidhe, swollen by the melting snows, could be heard from afar. The lochan -Lochan Buidhe, or the Yellow Lochan-where the stream has its birth was still covered with snow and ice, and for the first part of its course the burn ran completely under the snow. Then it emerged for a few yards, was again imprisoned, and finally ran free, with great ice floes lining its banks. A wonderful scene for the last days of May, and one which must be rare in Scotland at any time.

Ptarmigan croaked on the plateau. Their season of nest- 


\section{Wanderings of a Naturalist}

ing had been retarded by the late snows, and it would be a fortnight yet before the hens were brooding. As I sat in a sheltered part of the hillside I noticed a couple behaving in a curious manner. Through the glass they were seen to be two cocks, and the birds were evidently rivals for the affections of a hen somewhere near. In great excitement they pursued each other backwards and forwards across the hill face, now flying low over some great snowfield, now racing at express speed above some rocky scree. Anon they would alight together in the snow, pause a moment, perhaps for breath, then run rapidly across the snow parallel to each other, with wings outspread. Then one of them would once again take hurried flight and the other would pursue him. Once the birds passed not more than six feet from where I sat, and so intent were they on their own affairs that they paid not the slightest attention to me. From time to time one of them disappeared, and I imagined that the dispute had been settled, but a few minutes later the pursuit was as furious as ever.

Near Lochan Buidhe a couple of hinds were spied crossing a field of snow. From the direction of their tracks they seemed to have come from the Glenmore side, attracted to the tops, probably, by the sudden heat, for here there was as yet no grazing of any kind. At Lochan Buidhe the watershed is very narrow. Within a hundred yards of the birthplace of the Feith Bhuidhe burn, the March burn (which appears in the Lairig Pass as the Pools of Dee) rushes down the rocky face of Ben MacDhui, so that waters which flow respectively into Spey and Dee almost mingle at this point. Looking down into the Lairig beneath me, I could see that even here winter still lingered. Two of the Pools of Dee were still buried beneath snow and ice, and big snowfields covered the steep face of Sron na Lairige.

But the most remarkable scene for the season of the year lay towards Cairn Toul and the Garbh Choire. The latter was quite filled with snow, and round the top of the rocks 


\section{A Day on the High Tops}

everywhere great cornices hung. In Cairn Toul there lies, sheltered from sun and wind, a gloomy hill loch, Lochan Uaine. To-day this loch was entirely covered with a sheet of unbroken ice over which there spread great cracks. The last occasion on which I had seen this loch was on the preceding November 7 , when it was frozen hard, so that it had been in the grip of the ice for close on seven months. Crossing by the ridge of Creag na Leacainn, I descended to the Lairig, just before the commencement of the wood that extends up the pass a little way from Rothiemurchus. On my descent I passed many ptarmigan, and was interested to find at elevations ranging from 2,800 to 2,700 feet quite a number of small and stunted specimens of the Scots pinePinus sylvestris. I had once found an isolated specimen at this height in the Garbh Choire, but had never seen a number of trees growing at such an altitude. The seed had probably been blown up from the pines which grow in the Lairig, not far from the hillside.

In the glen the heat was intense, and Allt na Beinne-Moire was in full flood with the melting of the snows. All around was the aroma from many pines and birches, so that it was a pleasure to pass through the woodlands filled with the young growth of springtide. Two capercaillie rose at my feet, and redstarts flitted from tree to tree as I passed. At Aviemore that night the temperature at 9 p.m. exceeded 70 degs. Fahr., and not a breath of air stirred. Spring had been backward, but she came at length to the hills in the form of full summer, and it was not long ere the snows had gone, and in their stead the high tops were clothed with green hill grasses and tinged with the flowers of many plants of the creeping azalea and the cushion pink.

Less than a fortnight later a great change had taken place on the hills. From May 27 until the morning of June 5 the high tops were almost continuously hidden by mist and rain; but on June 5 , after a cold and misty morning, the 


\section{Wanderings of a Naturalist}

sun broke through the clouds shortly after ten o'clock, and the remainder of the day was beautifully clear and sunny. Though mist had hidden the hills during the fortnight since my previous visit to the high tops, the air had been mild, and there had been no frost.

From the great plateau stretching from Ben MacDhui to Cairngorm the snowy covering by now had disappeared, with the exception of a few large snowfields in sheltered hollows. The Feith Bhuidhe burn was now snow-free almost throughout its course, and Lochan Buidhe was unfrozen except for a little ice and snow at its western end. All the burns of the high plateau had shrunk remarkably in size. For example, the March burn, where it passes on its way down the hill face of Ben MacDhui within a hundred yards of Lochan Buidhe, was on May 25 a big rush of water. By June 5 it had dwindled to a mere trickle. This had resulted mainly through the melting of the snows, but partly from the considerable drop in temperature during the first days of June, when the melting of the remaining snowfields was considerably slowed down.

Although the high ground was now comparatively snow free, there was as yet no growth amongst the upland vegetation. The previous year, in early June, even the highest grounds were green, and Silene acaulis and Azalea procumbens were in flower. I should say that in the season of which I write-1920-the plants of the high hills were almost three weeks later than in previous years.

Mast of the ptarmigan had now commenced to sit. One nest I saw from which, judging by the feathers lying around, the sitting bird had been captured by a fox; the eggs lay in the nest, but all had been sucked.

Cairn Toul, a fortnight earlier, had been almost entirely snowclad, as seen from Ben MacDhui. Now, however, much of the snow had gone from it, and from Lochan Uaine the ice had melted, with the exception of a few half-submerged icebergs. The Garbh Choire was still almost filled with 


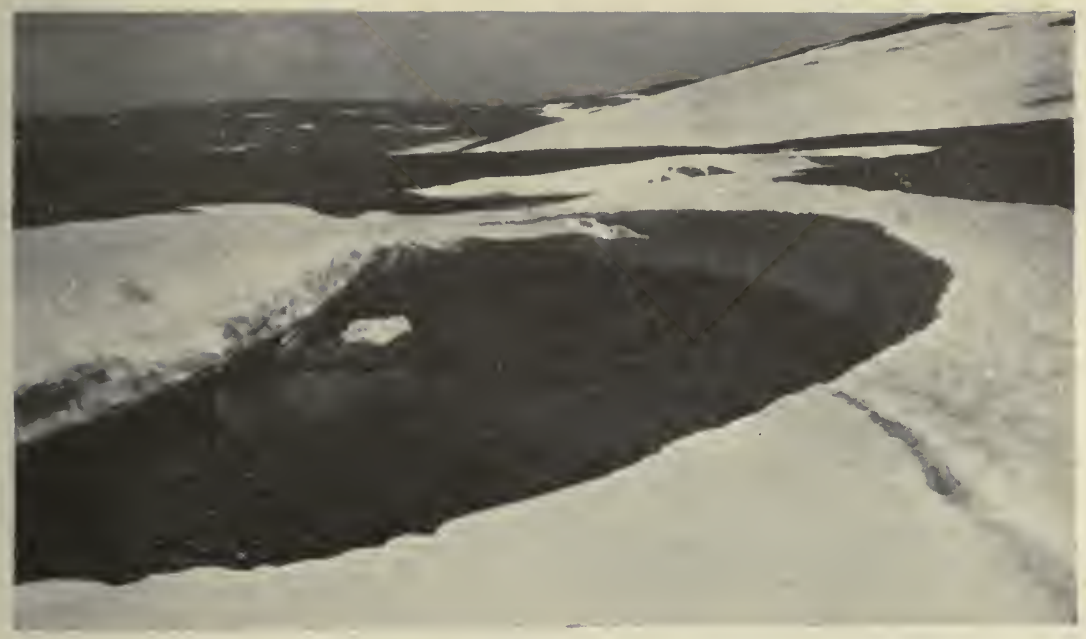

A Hill Burn of the Ben MacDhui Plateau Half under Snow.



Garbh Choire Mhor.

The Corrie is here entirely mist-filled, and above the mist can be seen a thin grey line of haze. In the foreground is a snowfield, and from here to the foot of the Corrie is a sheer drop of about $2,000 \mathrm{ft}$. 


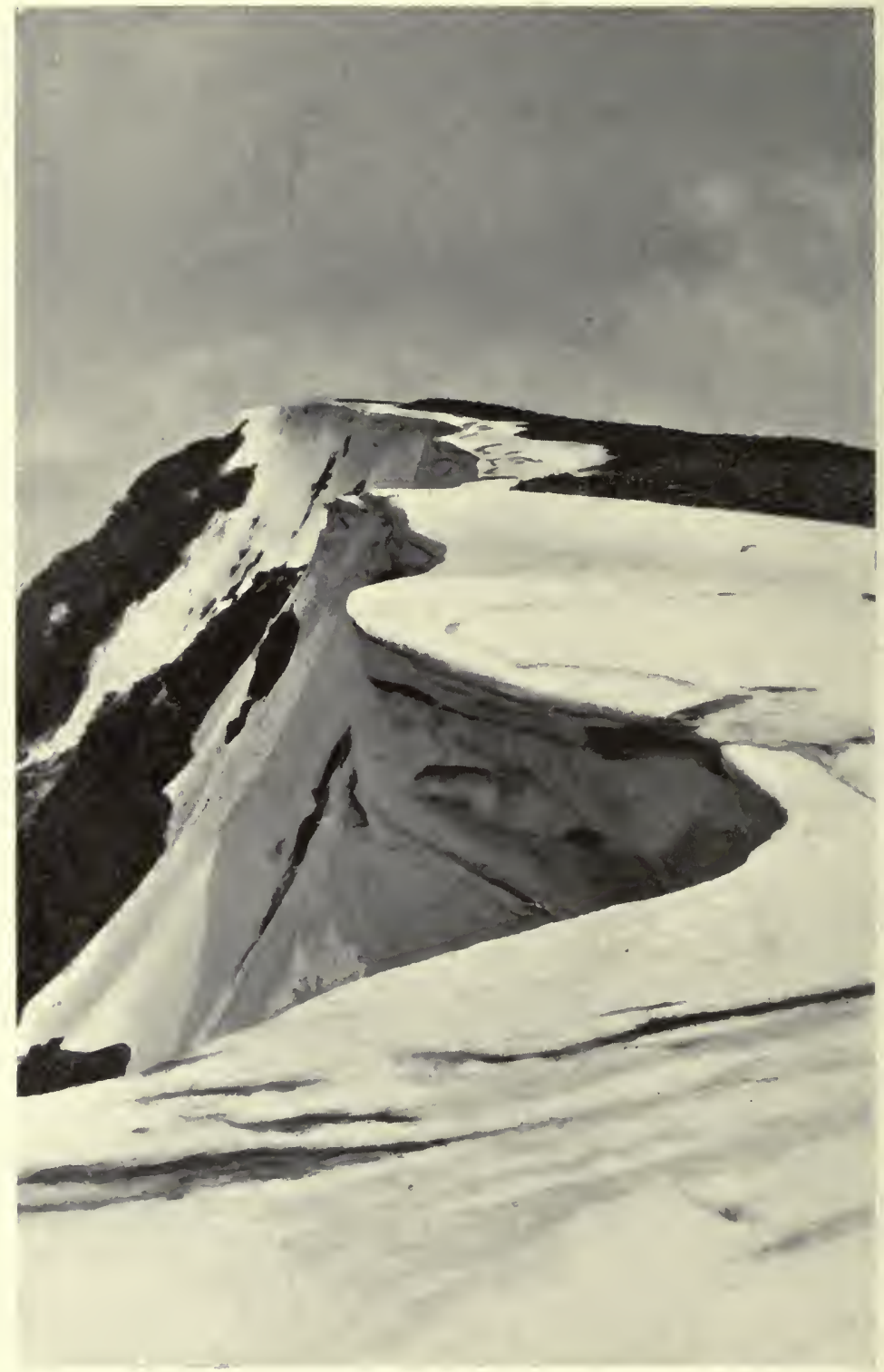

EARLY JUNE AT THE HILL-TOP: SGOR AN LOCHAN UAINE. 


\section{A Day on the High Tops}

snow, and on Braeriach great fields and cornices remained. The distant hills were distinct, and the large snowfields on Ben Nevis were prominent. Big snow wreaths could be seen covering the high ground above the Dubh Loch on Lochnagar, but Beinn a' Ghlò was almost free of snow, and Beinn a'Bhuird and Beinn Avon were also in like case as seen from the west.

As usual, the eagle was at his hunting above the plateau, and sailed across the grass-grown corrie known as Coire mhor na Lairige. Scarce a breath of wind stirred, and the sky was of a very deep blue and almost cloudless, except where, far to the south, a layer of white cumulus clouds gathered.

In Coire an Lochan of Cairngorm, a fresh avalanche of great frozen blocks of snow lay piled up near the lochan.

Late that evening the hills were extraordinarily clear, but before dark a strong and cold northerly wind brought mist once more to their tops, and this continued to hide them for some days. 


\section{CHAPTER XIV}

THE ARGYLLSHIRE COAST AND ITS ISLANDS

WIDE county is Argyll, and one of many contrasts.
On the one hand, Dunoon, its capital, is not more, one
might say, than a stone's throw from the great city of Glasgow, and, on the other, most of its coast line and all its islands are wild, hardly accessible, and peopled with a Gaelicspeaking race. At its northern boundary-Loch Shiel-one is in the very heart of the Western Highlands, and the great hills rise up, tier upon tier, from the blue waters of the Atlantic. One sees from here, of a clear June morning, the jagged Cuchulain Hills rise steeply from the Isle of Skye, the conical hills about Knoydart, and those of Loch Nevis; while out to sea are the mountainous island of Rhum, andnearer at hand-Eigg, the home of many birds.

Argyll is a county of many islands. To this shire there belong Islay, within easy view of the north Irish coast-I have seen, of a winter's morning, from Malin Head, Islay's hills rise snow-capped from the blue Atlantic-and Jura, with its three conical and conspicuous hills which seem to attract to themselves more mist-clouds than any other mountains of the West. Then again, northward of Jura, there lies the large and fertile Isle of Mull. "Muile nam mor bheann" is its Gaelic name, and it is a land of mountain and corrie except for its westernmost peninsula, known as "the Ross," which stretches away from Carsaig to the Sound of Iona, and though heather clad, is comparatively level. Supreme among the Mull hills is Ben Mor, which rises from the waters of Loch Scridain and Loch nan Ceall to a height of just under 3,200 feet. In the corries of Ben Mor is fine grazing, so 


\section{The Argyllshire Coast and its Islands}

that the stags on this hill are of remarkably heavy weight. Of the lesser hills, there is Dùn dà Ghaoith (the Hill of the Two Winds), rising to a height of 2,500 feet straight from the deep waters of the Sound of Mull, and Beinn Buie, beside the sea loch of the same name. Although this hill is not more than 2,200 feet in height, ptarmigan nest on its slopes, for it seems to be the case that on the Atlantic seaboard these birds habitually frequent hills which in the central Highlands would be too low for their requirements by a full 500 feet.

At Lochbuie is the ancient seat of the Maclaines of that ilk, and near the sea loch is a hill lochan known as Loch Sguaban. It was here that one of the Maclaines-Ewen of the Little Head-was slain in a clan fight, and it is said that his spectre may still be seen seated on a black steed which thunders around the castle of the Maclaines before a death in that family. Not many miles from Lochbuie is the seat of another branch of the clan. The Laird of Duart -Colonel Sir Fitzroy Maclean, Bart.-spells his name in the more usual way, and is now almost universally acknowledged to be the chief of the clan. The dispute between Maclaine of Lochbuie and Maclean of Duart-or Dowart, as it was formerly spelled-over the chieftainship arises from the fact that the two families trace their descent from twin brothers, and some uncertainty exists as to which of these twins was the elder.

The Castle of Duart, until recently a ruin, has been restored by the present chief, and overlooks the Sound of Mull at the entrance to the Firth of Lorne. Bleak and windswept, it nevertheless commands a view that is unsurpassed throughout Scotland. From here one looks straight up the Linnhe Loch to where, in the background, there stand Ben Nevis, flecked with snow until far on into the summer, and the conical hills that surround Glen Coe. In olden days the Macleans were the most powerful clan in these parts, and the chief possessed extensive lands in various districts of Mull, and in Morvern on the mainland opposite. He also owned 


\section{Wanderings of a Naturalist}

the distant Isle of Tiree, lying in the Atlantic more than twenty miles to the westward of Mull. Nothing more windswept than this flat island can be imagined, so that it is unexpected to learn that the chiefs of that day migrated thither from Duart at the coming of winter.

Along the western side of the Isle of Mull the scenery is exceptionally fine. Here the coast is deeply indented by the Atlantic, and almost joining one another are three wild and beautiful sea lochs, by name Loch Scridain, Loch nan Ceall and Loch Tuadh, or in English the North Loch. Immediately to the south of Loch Scridain, and near its entrance, lies the world-famous Island of Iona, where Saint Columba took up his abode during the seventh century, after leaving Ireland, his native land. Iona is separated from Mull by the Sound of Iona, a strip of water just over a mile across. But even this narrow passage is sometimes impassable during the winter months for over a week at a time, for through the Sound a very strong tide runs, and a heavy swell rolls in from the main ocean to the south. The one hill on Iona is only a few hundred feet in height, but from its summit a wide view is obtained over land and sea. Far out into the Atlantic, should the visibility be good, one can see the lonely lighthouse of Dubh Hirteach. Here, I believe, on one occasion the waves were so tremendous that they smashed into fragments the strong glass encasing the reflectors at the very top of the tower. What on this occasion must have been the feelings of the light-keepers, absolutely cut off from the outer world, with the lighthouse rocking and quivering as it was struck by each enormous wave in succession?

To the west of Dubh Hirteach there lie, some ten miles south-westward of the Island of Tiree, a number of dangerous rocks, many of them showing only at low tide. On the largest of these rocks, by name Skerryvore (Gaelic, Sgeir mhor, or big rock), is a fine lighthouse of granite. It is only during a storm or high spring tide that this rock is awash even at high water. From the lighthouse tower the 60 


\section{The Argyllshire Coast and its Islands}

scene here is a very grand one, extending over miles of rock-strewn waters, where the Atlantic rollers break with muffled roar and white cascades of foam. One winter an American steamer had what the light-keepers consider to have been a marvellous escape from destruction on these rocks. The steamer's propeller had been stripped of all its blades by a succession of gales and heavy seas, and before a north-westerly gale the ship was drifting helplessly down to the rocks, but was carried past through a narrow passage of deep water, reaching the shelter of the Island of Tiree, and anchoring there till the storm subsided.

Of the two Argyllshire islands of Coll and Tiree, which are separated from one another by a narrow strip of water known as the Sound of Gunna, Tiree is by far the more fertile, and, indeed, this island produces crops unsurpassed in any of the Hebrides. Among the curious tributes which Tiree paid to the chiefs of the Macleans in olden days-the island passed into the possession of the Argyll family early in the seventeenth century-were the following items, which nowadays read somewhat quaintly: A payment of a sail and hair tackle to Maclean's galley; free quarters for the falconers and lambs for the hawks; also quarters for all the gentlemen's men-not under one hundred in number-who were accustomed to wait upon Maclean during his winter stay upon the island.

Lying in the Passage of Tiree-that part of the Atlantic between Mull and Coll-is a small group of grass-grown islands, the Treshnish Isles by name. The most outlying of these is known in the Gaelic as Bac Mor (or the Great Mound), but to it for well over a century has been given the English name of the Dutchman's Cap, from its fancied resemblance to a round crowned hat. A couple miles nearer to Mull lies Lunga, and clustering about it are a number of smaller islands, among them Carn a' burg mor and Carn a' burg beag. On Carn a' burg mor is the ruin of a fortified castle, one of the early strongholds of the chiefs of the 


\section{Wanderings of a Naturaiist}

Macleans. In the year 1679 a great expedition was organized against Mull by the Earl of Argyll. In the course of this expedition Carn a' burg was besieged and its castle taken; probably this is the last occasion on which this famous old castle figures in the conflicts of the clans. Old records show that no fewer than 200 galleys and boats conveyed 2,647 men to Mull, among them many pipers, on that famous expedition.

In former times each Highland chief had his piper, who accompanied him on all his travels. Many of these pipers were hereditary, the most famous family of them all being the MacCrimmons, pipers to the chiefs of the MacLeods. The MacCrimmons had their piping school at Borreraig in the Isle of Skye, where pupils assembled from all parts of the Highlands and even from Ireland, to be instructed in the Coel Mor or "big music." At the present day piping in Mull and the adjacent islands is a little known art. The only man, to the writer's knowledge, who can play many of the old tunes is a veteran of over four-score years in the island of Coll, who bemoans the fact that none of the younger generation of pipers on that island will be able to carry on the old music after his death.

At the present day the Treshnish Islands are quite uninhabited, and are interesting to the ornithologist from the great numbers of seafowl which frequent them during the nesting season. Thither these come with the fine days of early summer razorbills, guillemots, and puffins-the latter bird in its thousands-so that the sea around is animated and cheerful always during that season.

A fine climate has this western coast and these sea-girt islands of Argyll. Though the rainfall is high, the number of wet days seem to be no greater than along the eastern coast of Britain, though when it rains it does so in much heavier volume. The air is soft and mild without being relaxing, and the harsh winds of the north-east coast rarely penetrate here. 


\section{CHAPTER XV}

\section{SUNRISE FROM SGOR AN LOCHAN UAINE}

$\mathrm{L}^{\mathrm{vi}}$

ING a little to the north-west of Cairn Toul, and reaching an elevation of just under 4,000 feet, is the wild and storm-scarred point known in the Gaelic as Sgor an Lochan Uaine, or the Cliff of the Small Green Tarn.

Eastwards, the ground dips sheer to the Garbh Choire beneath; westwards the land flows away gradually, and two hill burns have their birth in the hollows known as Clais an t' Sabhaill and Clais Luineag respectively. A wild and barren peak is this, which gives a home to no bird or beast; to few plants even can the exposed rocks offer a foothold. At times an eagle, sailing across from Mar perhaps, or from Rothiemurchus, may alight for awhile on its stony summit, or a ptarmigan may shelter behind the rocks on its leeward face should the wind blow strong and cold from the Garbh Choire beneath, but still it is a place altogether desolate, and given over to the storms and to the hurrying mists.

But when fine June weather comes to the hills, and when the sun shines full on ridge and corrie, the grim sternness of this weather-beaten point is softened somewhat, and amongst its granite rocks plants of Silene acaulis burst into life and carpet the ground with a profusion of beautiful flowers of crimson or pink, while in the crannies parsley ferns gradually uncurl their fronds of softest green.

It was early one afternoon of June that a companion and I left the shores of Loch Einich-that fine hill loch lying beneath the dark rocks and green corries of Sgoran Dubhand made our way over Coire Dhondail to the wild expanse of high and comparatively level ground stretching away to 


\section{Wanderings of a Naturalist}

the west of Braeriach, and known as Moine Mhor or the Great Moss. In the corrie much snow still remained where it had been drifted in before a winter's gale from the southeast, and near the ridge a large snowfield hid the track near its steepest and most rocky point. A cock ptarmigan rose ahead of us at an elevation of not more than 2,000 feet-an unusually low level at which to find these birds on the Cairngorms-and no doubt he had a sitting mate near.

Great fields of snow still lingered in Coire Odhar and fringed the corries of Sgoran Dubh-Coire Mheadhon, Coire na Cailliche and Coire nan Each-the brilliant whiteness of the snowbeds contrasting strikingly with the fresh green grass and blaeberry plants growing just beneath them. Sailing along the ridges of Braeriach in the teeth of a northerly breeze, a golden eagle passed us by, and on the hillside were the feathers of some luckless ptarmigan he had captured. The track reaches the plateau of the Moine Mhor at about the 3,000-foot level, and from here a magnificent view lay westward-Ben Lawers, Schiehallion, Ben Alder, Ben Eibhinn, all stood out, their east-facing corries very heavily marked with the winter snows. Away behind them rose Ben Nevis, and, bearing northwards, and still more distant, the sharp peaks of Knoydart. At our feet lay Loch nan Cnapan, with ice and snow still covering its western shore, and perhaps a couple of miles east of it, Loch an Stuirteag, on the march between Mar and Glenfeshie. All the high ground carried considerably more snow than usual for the time of year, and vegetation was unusually backward. In Horseman's Corrie -named, so it is said, after a former tenant of Glenfeshie forest - the usual extensive snowfield remained, and from it flowed a large and swift-flowing burn of beautifully clear water.

Clais Luineag, on its western side, was almost entirely beneath snow, and here, beside the source of the burn-which for the first mile of its course was flowing beneath a continuous snow bridge-we pitched our tent at a height of about 3,600 


\section{Sunrise from Sgor an Lochan Uaine}

feet above sea level. Towards sunset the wind died away, and the stillness was intense. No croak of ptarmigan was to be heard in the corrie-the snows had driven them lower for their nesting-and no song of the snow bunting was carried down to us from the scree above. At I.30 a.m. we left the tent, making for Sgor an Lochan Uaine, just above us. Though by Greenwich time the hour was but half an hour after midnight, the sky in the north-east was already bright, while low down on the western horizon the bright warm light of Jupiter contended with the dawn. Gradually the light strengthened, but it was not until seventeen minutes past three (Greenwich mean time) that the sun, rising from behind the high ground midway between Cairngorm and Ben MacDhui, transformed the great snow cornice fringing Sgor an Lochan Uaine, so that it was bathed in a pale rosy light.

From the time the sun first appeared until his red ball was fully above the horizon exactly five minutes elapsed, and during this time his rays had reached Monadh Mor, with its great snowfields, and Beinn Bhrotain, with deep corrie facing away towards the valley of the Dee. For perhaps half an hour before the sun actually appeared, the horizon northeast burned brightly, and one single ray shot high into the sky. The waning moon had by now risen above the scree on the western slopes of Cairn Toul, and momentarily paler did she seem in the fast increasing light. About this time the western sky was strikingly and unusually beautiful. Along the horizon lay a bank of dark grey haze. Above that was a wide band of a greenish tinge, merging into a dull pink, which reached almost to the zenith. Singularly fine did the eternal snows of the Garbh Choire seem when flooded by the rays of the rising sun. Right beneath us lay dark Lochan Uaine, but newly freed from its icy covering. So still were its waters that it was hard to distinguish them from the surrounding corrie, and in them lay reflected the images of many snowfields. Then across the wide and rock-strewn Garbh Choire one saw the infant 


\section{Wanderings of a Naturalist}

Dee showing for a few hundred yards down the precipitous face of Braeriach before abruptly plunging beneath the snows, which held it imprisoned throughout almost the whole of its early course.

It was shortly after sunrise that there commenced to form away down in Glen Geusachan, far beneath us, a tiny wisp of thin grey mist. Increasing steadily in size, the small cloud, as it rose, caught the rays of the sun with fine effect. Gradually filling Glen Geusachan, the cloud overflowed west through the dip in the hills where lies Loch an Stuirteag, wafted by the lightest of easterly breezes which had now sprung up. At the same time a like cloud was forming in the Garbh Choire, and away towards the south and south-west similar clouds were lying in the valleys, especially towards the Forest of Gaick. Although the air was apparently mild, a keen frost was now binding the ground, so that the sphagnum mosses were crisp under foot, and a layer of black ice was formed on the water issuing from each snowfield, the snow itself being as hard as iron to the foot.

For some time past a cock ptarmigan had been croaking from the boulders of Clais an t' Sabhaill. Evidently his mate was brooding somewhere near, and the presence of intruders was affording him no little anxiety.

The sun was well above the horizon as we reached the plateau of Braeriach, and the hill looked very fine in the clear morning air, the young grasses contrasting strongly with the granite-strewn plateau on which snowfields still lingered. On the plateau an old hind was grazing on the tender grasses. She was remarkably tame, allowing us to approach to within a few yards, and then walking on ahead of us with evident annoyance at being so unwarrantably disturbed at her feeding; but after about fifteen minutes she suddenly got a whiff of our wind, and with this confirmation of the presence of her hated enemy she galloped instantly across the shoulder of the hill and beyond our sight.

By nine o'clock, from the precipices of Braeriach, the 66 


\section{Sunrise from Sgor an Lochan Uaine}

Garbh Choire presented a wonderful sight. The whole of the corrie and the Lairig were filled with a soft billowy mist, on which the sun shone with almost dazzling brilliance. From this sea the upper reaches of Ben MacDhui emerged and the top of Cairn Toul. Gradually, imperceptibly, despite the power of the sun, the mists rose higher, and as we watched, all ground below the 4,000-foot level was enveloped, though above us the sky was still of an unclouded blue. South-west we saw, one by one, the tops of the high hills disappear; Ben Lawers and Schiehallion for a time kept their summits mist-free, but gradually were forced to yield to the advancing vapours. Due west, however, the cloud layer did not appear to reach beyond Ben Alder, and across the intervening mists Ben Nevis towered, its height seeming enormous from the clouds that lay low on hill and glen between us and it.

At length, shortly after ten, the mists, in their unrelenting upward course, appeared on the plateau of Braeriach itself. At first only in halting wisps did they venture thus far, and the sun dispelled them easily. But ever denser did they press forward, and more quickly too, so that the sun battled in vain against the invading force, and soon the plateau was shrouded in gloom and clammy vapours, through which came from time to time the croaking of an unseen ptarmigan, and the murmur of the rushing Dee in the Garbh Choire far beneath. 


\section{CHAPTER XVI \\ THE NESTING OF THE STORM PETREL}

THERE is probably no sea bird having its home on or around the British Isles whose life and habits are so wrapped in mystery as those of this charming and diminutive petrel. In length smaller than a swallow-the latter bird measures seven and a half inches, whereas the storm petrel is only six and a half inches-it closely resembles this bird in the grace and buoyancy of its flight. Compared with the house martin, the length of the two birds is exactly the same, and they superficially resemble each other in their dark bodies and the strikingly contrasting white feathers on the rump.

The storm petrel (Hydrobates pelagicus) is essentially a bird of the ocean, and is at sea throughout the year excepting when engaged in rearing its young. It is easily the latest sea bird to nest, and it is, perhaps, due to this fact that comparatively little is known of its nesting habits. During a recent summer a companion and I spent a good part of the nesting season camping on an uninhabited island of the Hebrides, where many of these little petrels had their summer home.

The last days of June were wild and stormy, with great cold for the time of the year, and it was not until the morning of July 2 that we were able to sail out to the island where we hoped to find the birds. The owner of the island-a keen naturalist-readily placed his boat at our disposal and accompanied us. A more beautiful summer day it would be difficult to imagine. Hardly a breath of wind ruffled the waters of the Atlantic and the sun shone brilliantly, lighting up hill and 


\section{The Nesting of the Storm Petrel}

island with a singular clearness. On the way to the island where we intended to camp we called at a smaller islandalso much resorted to by petrels-but for long were unable to discover any traces of the birds. Ultimately two storm petrels were found, brooding on newly laid eggs, while a third bird was evidently about to lay. The nesting ground was beneath the ruins of an old fortified castle, and the birds were hidden away among the heaps of stones of various sizes which had fallen from the rock above as the castle gradually crumbled. Generally the nesting site is far down among the loose stones-some of the eggs we subsequently found were two feet below the surface level-but to-day one of the birds was in so exposed a position that her tail could be seen, without disturbing a single stone, as she brooded her one egg. In the two "nests "-if such they may be called-which we examined, the single round white egg was laid on the bare ground without any kind of nesting material; but in certain nests we found subsequently the egg reposed on a layer of dried grasses, though it looked as if the latter might have been there by accident, having perhaps been blown into the hollow by winter storms. The parent birds, probably dazed by the brilliant sunshine after the twilight of their nesting sites, showed little disposition to fly, and even when placed in the hand remained there in a dazed state. One of the illustrations shows a storm petrel standing beside her egg, and gives a fairly accurate impression of the nesting ground. When they did take wing, the birds flew out to sea with graceful, swallow-like flight.

Leaving this small island in mid-afternoon, we soon reached the larger island, and before sunset pitched our tent on a grassy slope just above high-water mark. Near the centre of the island is a small hill, and from there that evening we watched the sun sink behind the hills of South Uist at exactly twenty-two minutes past ten.

So far we had seen or heard nothing of the birds we hoped to study, and it was not until the following afternoon that we 


\section{Wanderings of a Naturalist}

heard the first storm petrel calling from the interior of a low half-ruined wall. We discovered the bird after some difficulty, but found that it had not laid as yet. That evening was dull and quiet, and after having walked to the far end of the island in order to erect a hiding-tent near the nest of a great black-backed gull, we returned at dusk to where we had located the petrel in the afternoon. By now several pairs of the birds were calling from among the stones, so we sat quietly in the neighbourhood till past midnight (British summer time).

The mating note of the storm petrel, for this I believe the calls to be, is a curious and fascinating purring sound, commenced in a very low key, and rising gradually until the final note, which is high-pitched, the whole song being uttered without pause. It is impossible to render it into words, but once heard it can never be forgotten. The bird continues this song over and over again quite undisturbed, even when one is standing immediately over it, but when the stones above it are moved, it quickly becomes silent, and once alarmed does not readily re-commence its song. One individual repeated its "purring" without a pause for over an hour, at the end of which time we left the nesting ground, with the small petrel still continuing its song.

At about in p.m. (B.S.T.) what were probably the coclis began to leave their holes and flit bat-like backwards and forwards, while the hens remained to brood their eggs. Many moths were on the wing, and the petrels were apparently hawking them-a trait in the character of this bird already chronicled by Yarrell. Throughout the island the storm petrels were very active on this particular night, apparently liking the soft atmosphere and dull sky. At one point we heard a pair, only a few feet from us, purring repeatedly as though pairing. On their taking wing it was seen that they had been standing on a large boulder, and this was the only occasion on which we recorded them perched in the open and purring as they habitually did in their holes. 


\section{The Nesting of the Storm Petrel}

One had, this night, a sense of the remoteness and solitude of the island. On the horizon the lighthouses of Skerryvore and Dubh Hirteach periodically pierced the gloom with their rays, while nearer at hand was the strong and steady light of Ardnamurchan.

The next morning, near the rock from which we had seen the petrels take wing the night before, we discovered a pair of these birds at the end of a rabbit burrow in an old wall, but no egg had been laid as yet. That evening was cloudless, and the petrels were almost silent, though one individual was purring in some stones near our tent.

A few days later-on July 8-I discovered a storm petrel brooding her egg in such a position that she could be seen by removing one stone only, and as this could be done without disturbing her, I marked this particular nest for future observations. After a warm and sunny day a strong cold north wind brought with it mist and gloom at sunset, and during the night, from our tent-which, by the way, was only a few yards from where a colony of storm petrels nested-we could hear the petrels flying round restlessly and excitedly. On July 9 we discovered another pair of petrels in what was evidently to be their nesting site, but no egg had been laid. During the night of July IO-I I the weather changed, a southwesterly wind bringing with it thick mist and drizzle. About $3 \mathrm{a} . \mathrm{m}$. on the IIth we were awakened by extreme excitement on the part of the petrels, the birds chortling loudly as they dashed about. Their call was a most extraordinary sound, extremely weird and un-birdlike, and may, perhaps, be likened to a very asthmatic old gentleman endeavouring to clear his throat. This cry was apparently never uttered except when the birds were on the wing, and only on wild and dark nights.

During the fortnight that we camped beside the nesting ground of the storm petrels we found that the birds left the stony crevices about II.30 p.m. and returned to them shortly after 3 a.m.-both times B.S.T.-giving them only a very 


\section{Wanderings of a Naturalist}

short period in which to feed. Apparently those birds which emerged fed over the land, for they could be seen flitting around bat-like throughout the night. It would be interesting to learn whether on their return they fed their mates, who evidently remained behind to brood their eggs, for they could be heard calling among the stones from dusk to daybreak. In this connexion it may be stated that it has been established that both cock and hen petrels take their share in incubating the egg, and that the two sexes are indistinguishable in colour and appearance.

On this island the favourite nesting sites of the storm petrels were among the large rounded stones which were heaped up on the shore just above the level of the highest spring tides, though the birds also nested in half-ruined walls and under isolated rocks inland. But as the island is less than half a mile in breadth, the petrels could from any point leave their holes and be over the ocean in a few seconds' time. During the hours of daylight the birds were never seen, although in dull weather they could be heard purring beneath the cairns of stones where they nested. As a rule, they seemed to prefer to nest apart from other sea birds, but in one instance a pair took up their quarters in an old wall in the midst of a colony of puffins.

A strong, though not unpleasant, musty smell pervaded not only the nesting hollows of the petrel, but the rocks for several feet on either side, and after a good deal of experience we found the surest way of discovering the nest was by following up the scent.

We left the island on July 15-by which time almost all the storm petrels had laid-and were unable to revisit it until August 23, a fine sunny day sandwiched in between two spells of rough, unsettled weather. On landing we at once visited the nesting site of the storm petrel which had been found brooding on July 8 , and were more than pleased to find that the egg had hatched out safely, and that a young bird, ten to twelve days old, nestled in the hollow. This 




The Storm Yetrel: The Parent Birds at the Entrance to their Burrow.

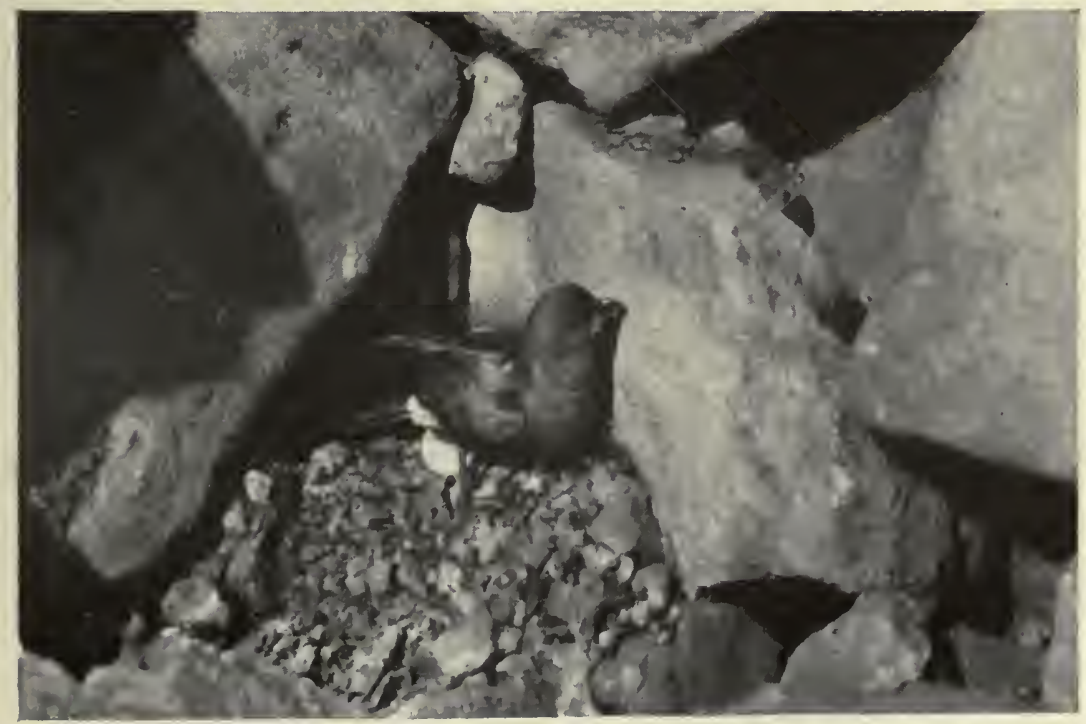

The Storm Petrel: The Bird and the Egg Exposed. 




Young Storm Petrel about a Fortnight Old. Note the bald patch on the head.

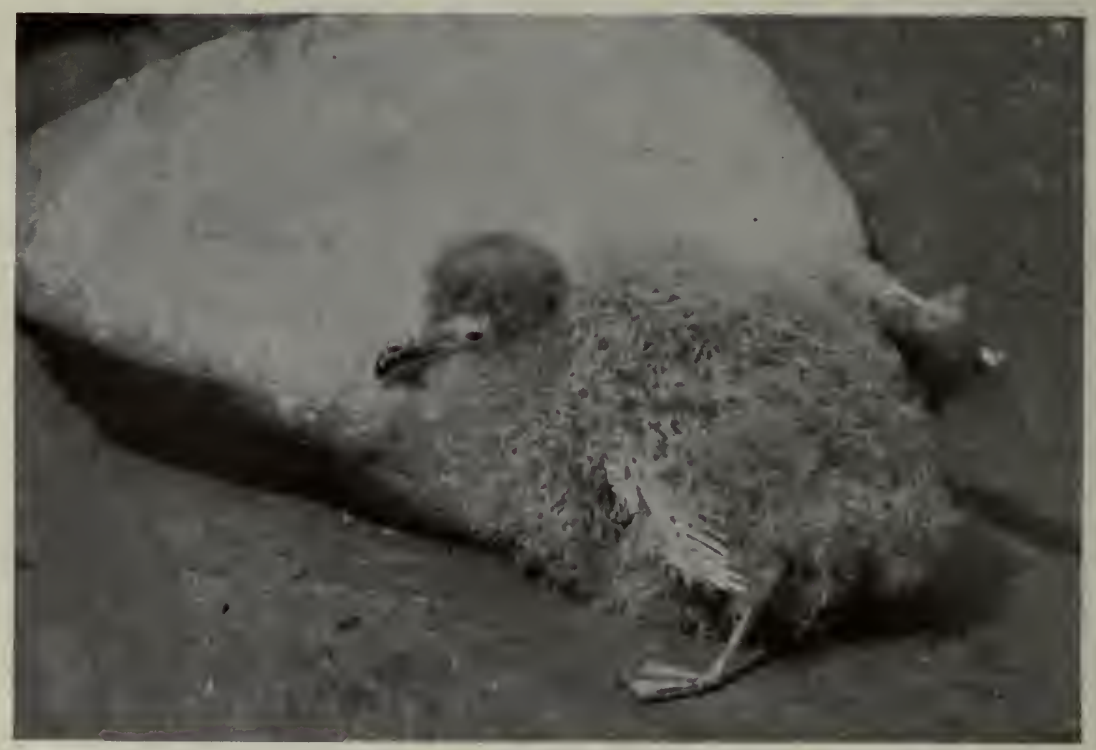

Young Storm Petrel perhaps a Month Old. The wing quills are just showing. 


\section{The Nesting of the Storm Petrel}

nestling, as we subsequently found to be the case with every chick we examined, had a curious circular bald patch on the top of the head. Its feet and bill were of a pale grey. Its shrill pipe closely resembled the whistle of a young oystercatcher. Having obtained some photographs of this chick we went on to the wall where, as mentioned earlier, we had on July 3 heard and found a storm petrel which had not then laid. This day in the same cranny we found a petrel-presumably the identical bird-brooding a tiny chick, which at the outside could not have been more than three days old. Mr. Eagle Clarke, one of our foremost naturalists, has informed me that, in his experience, it has been rare to find the adult bird with its young during the hours of daylight, so the accompanying illustration, showing young and old together, is the more interesting on that account. The parent bird on being disturbed ejected a quantity of brown oily substance, but beyond calling twice sharply, "Ka, ka," was silent. The newly-hatched chick, unlike the individual of a fortnight old previously mentioned, had its legs and feet almost pure white.

Later in the day we visited a stone wall where, on July 13 , a storm petrel was purring repeatedly, and where on the stones being disturbed the bird walked out to the light, but, thinking better of it, returned to the darkness of the interior of the wall. I had on this occasion an excellent view of the small and fragile petrel as she walked out from the darkness of her nesting site, and her walk was certainly graceful and easy. I was therefore surprised to read in the "British Bird Book" (Kirkman) that, according to all observers, the storm petrel never walks. This bird was still engaged in brooding an egg which, from its appearance, was on the point of hatching. It is said that a storm petrel's egg hatched out in an incubator on the thirty-sixth day, so it would seem that even this prolonged period of artificial incubation errs, if anything, on the short side.

On a small adjoining island we found another storm 


\section{Wanderings of a Naturalist}

petrel still incubating a hard set egg, also two nests containing very small young with eyes still closed. In each case the parent bird was in the hollow beside the young. One of the adult birds, on being lifted out into the light, uttered a musical swallow-like twittering. These small chicks gave away their place of concealment by cheeping loudly, although they were being brooded at the time. Perhaps they longed for their evening meal, although it wanted several hours to sunset. We also found a youngster two or three weeks old in a cranny near, but this one was quite silent.

On August 27, a wild day with a gale of north wind, we sailed out to another island and found the storm petrel nesting here also. Of the young birds which we examined, one was in quite a nest of dried grass; the other was lying on the bare earth. On August 29 we paid our last visit to the petrels' home. Again a gale of wind blew from the north, and a heavy sea was running, but our boat was an exceptionally seaworthy one, and we had at the helm one of the most trusty of steersmen.

On this day we discovered a new nesting site of the petrel, namely a narrow cleft in the rocks strewn with fairly large stones. Here we found four or five young petrels, one of which-nearly four weeks old-was the largest we had yet come across. Its wing feathers were sprouting, and even the white tail feathers were showing. Its legs and feet were by this time black, like those of the adult. When removed from its hiding-place it flapped its wings vigorously. One could plainly see the curious knob half-way down the bill-so characteristic of the petrel family-into which the nostrils open in a single aperture. Can it be that this knob is to protect the nostrils from the spray of the waves when the bird is at sea during heavy weather?

A second young bird-found a few yards away-with eyes still closed, was newly hatched, while a third was about ten days old. In the fourth nest which we examined, beside the young bird there still remained the egg of the previous year, 


\section{The Nesting of the Storm Petrel}

which had for some reason proved unfertile. This was interesting, as showing that the storm petrel is in the habit of using the same nesting hollow each season, and, indeed, in several other nests that I examined I found, lying beside the egg or young, portions of eggs of previous years.

During a subsequent season I had an opportunity of further investigating the breeding of these small petrels.

On August 18, a day when the high tops were snowcapped and the north wind already had in its breath a foretaste of winter, I marked one of the petrels which was brooding on a very hard set egg, which would have hatched in a few days' time at the outside. On October I3, exactly eight weeks later, I again visited the lonely island. After much rough and unsettled weather, mid-October brought summerlike conditions to the Hebrides. After a quiet sail the petrels' island was reached, and in the nest marked in August I was interested to find the young storm petrel, at first glance almost indistinguishable from an adult bird. On removing it, however, I found that on the whole of its under-parts the grey down still remained, though beneath it were the fully-grown feathers. There persisted small tufts of down on the scapulars also and on the back. A curious point was that its mouth had down adhering to it, seeming to show that the nestling had been engaged in pulling out its downy coat.

With the exception of a noticeable crest on its forehead, its plumage, even down to the conspicuous white rump, seemed to be entirely similar to that of its parents. This was interesting since few birds assume the adult dress before leaving the nest. As far as could be judged, this bird would have been ready to leave the nesting cranny in a week or ten days' time, so that, assuming the egg hatched within a week of August 18, the youngster must have remained a full eight weeks in the nest, probably a few days longer.

How protracted a period of fledging is this as compared with the house martin, a bird of a similar size, which remains 


\section{Wanderings of a Naturalist}

in its nest no longer than twenty-one days at the outside. What other bird also is still tending its young of the first brood in mid-October?

At another nesting site of the storm petrel about a hundred yards away a very small chick was found. Its quill feathers were only just showing, and it was about three weeks old, so that it could not have left the nest until the very end of November. This chick was apparently the result of a second laying, for a cracked egg was lying beside it.

One would imagine that a small chick left in late autumn in a dark hollow, draughty and cold, and unattended throughout the hours of daylight-for, as I have mentioned before, the storm petrel never broods its young in the daytime after the first week-would succumb to the harshness of the weather, but as a protection these fledglings have a coat of down of remarkable warmth and thickness.

What an extraordinary experience their first flight must be. After two months in the cramped quarters of a dark hollow to emerge one late autumn night and perhaps under the guidance of the parent birds to take to the water, and never approach land, or perhaps even see it, till the following summer.

In this connexion, Bishop Montgomery, writing* of the sooty petrel (Puffinus tenuirostris), which breeds in the southern hemisphere, gives a most interesting account of these birds. He makes the noteworthy observation that the young petrels are left by their parents in their nesting hollows after they have reached a certain age. After about a fortnight hunger drives them into the open air, and unaided they have to find their way to the water, where instinct alone must teach them to feed and fly.

It would seem probable that this may also be the case with the storm petrel, but its life history is so far little investigated.

" Cornhill Magazine-November, 1920.

76 


\section{CHAPTER XVII}

\section{CLISHAM : A CLIMB IN HARRIS}

$\mathrm{O}$

$\mathrm{N}$ the Island of Harris are many hills, and the highest of them all is Clisham, which reaches an altitude of 2,622 feet. No great height is this, as compared with the big hills of the Cairngorm range-Ben MacDhui, Braeriach, and Cairn Toul-yet it is nevertheless the highest hill in all the Outer Hebrides, and from its summit in clear weather a view unsurpassed may be had across hill and sea. Much weather of a very wet and misty character was experienced in the Hebrides throughout the second week of a recent July, and I do not think that during this period the summit of Clisham was once free of cloud. The morning on which I made the ascent opened promisingly enough, and when, accompanied by a companion, I left Tarbert, Harris, the sun was shining. But before we had made much progress along the northern shore of .West Loch Tarbert, a freshening southerly breeze brought with it heavy clouds, and rain commenced to fall.

Our way. for the first four miles led along the margin of the sea loch, but near the whaling station of Bunavon Eader -where, owing to the heavy sea running outside, the past few days had been unproductive-the road winds up a steep hill face to where, at a height of 600 feet above sea level, a chain of three lochs lie, surrounded by big hills. It was here that we left the Stornoway road, and struck up the face of Clisham, the upper reaches of the hill being shrouded by hurrying mists, but the sky southward giving promise of better things to come. As compared with the Cairngorms, these high hills of the Outer Hebrides are singularly devoid 


\section{Wanderings of a Naturalist}

of bird and animal life. 'A few yards from the road we flushed a somewhat sickly-looking cock grouse; but during the whole climb we saw, with the exception of the seagulls, no birds but a pair of meadow pipits. No curlew or golden plover cheered us with their musical cries; even the buzzard, which in the Island of Mull is numerous, seems quite absent here. About the summit of Clisham one or two pairs of ptarmigan are still said to be found, but during our. climb we came across no trace of them. The eagle was formerly to be found here, but has not, so I am informed, been seen for several years. There is scarcely any heather on the hill; grass extends from base to summit, and even at a height of 2,600 feet wild thyme was in flower.

During our climb the weather gradually improved, until the summit cairn was mist free ere we reached it. The cairn of the hill was moss-grown, and amongst the rocks saxifrages bloomed, with an occasional violet near them. Not many yards from the cairn are the remains of a rough shelter which the surveyors inhabited for three months some fifty years ago when making a survey of the district. For fuel they burned peats, and a certain sturdy Highlander carried a sackful of peats every day from the low ground to the summit of the hill, receiving for this very hard work the modest sum of Er per week.

During the time we spent on the hill-top the mist was never far above us, but was never really down on the hill. Curiously enough, Clisham, although the highest hill in Harris, was at this time the only one free from mist, due probably to the fact that it lies further removed from the influence of the Atlantic than the surrounding tops. This mist curtain extended all round except northward, and while giving some very fine effects, greatly restricted the view. At our feet lay West Loch Tarbert, the sun shining on its waters, ruffled by a southerly breeze, which seemed fresher at sea level than where we stood. Across the loch the large island of Taransay was prominent, with many rocky islets, known 


\section{Clishan: A Climb in Harris}

as the Taransay Glorigs, extending northward from it. Southward of Taransay, the Atlantic swell broke slowly on the wild headland known as Toe Head, and on the broad stretch of sands-Traigh Scarasta and Traigh an Taobh Tuathathe sun shone brightly. Beyond that again were the islands of the Sound of Harris, Pabbay, by reason of its hill, Beinn a' Charnain, being most noticeable. In the distance could be seen, stretching out into the Atlantic, the north-west point of North Uist. Westward the view did not extend far beyond West Loch Tarbert, though on a clear day St. Kilda can be seen from Clisham, the distance being roughly sixty miles. Almost at our feet there nestled the two small islands of Soay Mor and Soay Beag, close in towards the northern shore of the loch. A little north of west many hills stood between us and the Atlantic. Close to us, across Coire Dhubh, rose Mullach fo Dheas, less than 200 feet lower than Clisham (or The Clisham, as it is known to the natives) itself. Farther west Ullaval and Turga Mor $(2,227$ feet) were hidden in dark clouds. North lay Loch Roag, with its many islets, and had the weather been clear we should have seen, far out to sea, the group of the Flannan Islands or the Seven Hunters. Immediately below us the great Loch Langabhat lay blue in the sunshine, a strong breeze ruffling its waters.

The peninsula of Eye, with Tiumpan Head at its eastern extremity, could be seen indistinctly; but the view in this direction did not extend so far as the Butt of Lewis, or Rudha Eorrapidh, as it is known in the Gaelic language.

South-east lay Loch Seaforth, that long arm of the sea that penetrates inland, following a devious course, a distance of close on twenty miles. Sailing on its blue surface were two small boats, their crotal-dyed sails showing up as dark specks against the waters. Out into the Minch lay the group of the Sennt or Shiant Islands, soft sunshine lighting up their grassy slopes, where sheep graze. Near them a deepsea trawler was steering north, making perhaps for the Iceland fishing grounds, her mizen set, and smoke 


\section{Wanderings of a Naturalist}

trailing lazily from her funnel, with a fair breeze on her quarter.

South-east, and set far into the Minch-it is nearer to Skye than to the Harris coast-was the lonely Isle of Fladda Chuain, where is said to be the site of a chapel of St. Columba. Beyond it rose the high ground of the north of Skye, and more to the south we could make out the flat-topped hills known as MacLeod's Tables. The Cuchulain Hills were indistinct, and their topmost slopes hidden in mist.

Alpine plant life was scarce on Clisham. One missed the delicate flowers of Silene acaulis and Azalea procumbens-the latter an essentially granite-loving plant, and so unlikely to be found here. A few plants of the Alpine willow were growing round the summit of the hill, and from a ledge of rock a plant of rose-root bloomed.

As we left the hill and reached the small tarns beneath, the wind had dropped to the faintest of breezes, and northward the sky was dark and thundery. At the loch side a sandpiper with young broke the stillness with shrill cries of alarm, and far above us a raven circled and croaked, while on tireless wings the tribe of the gulls sailed high above the hill-tops, or, soaring downwards, alighted on the waters of the quiet hill loch, their plumage seeming the whiter against its peat-stained waters and the grim black rocks that towered behind it. 


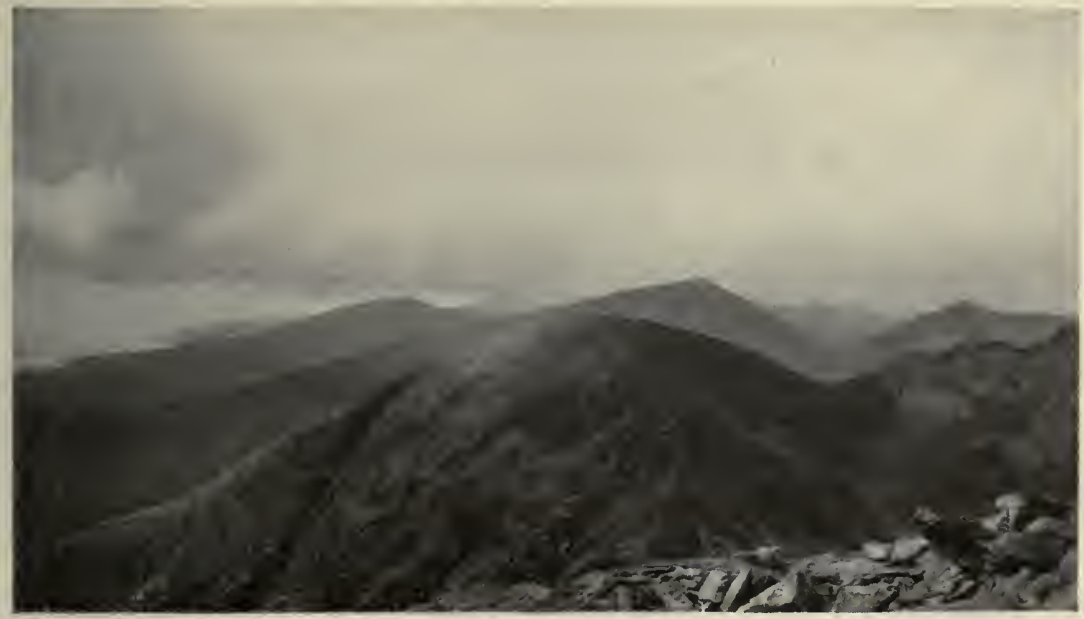

Looking North-West over the Conical Peaks of Harris from the top of Clisham.

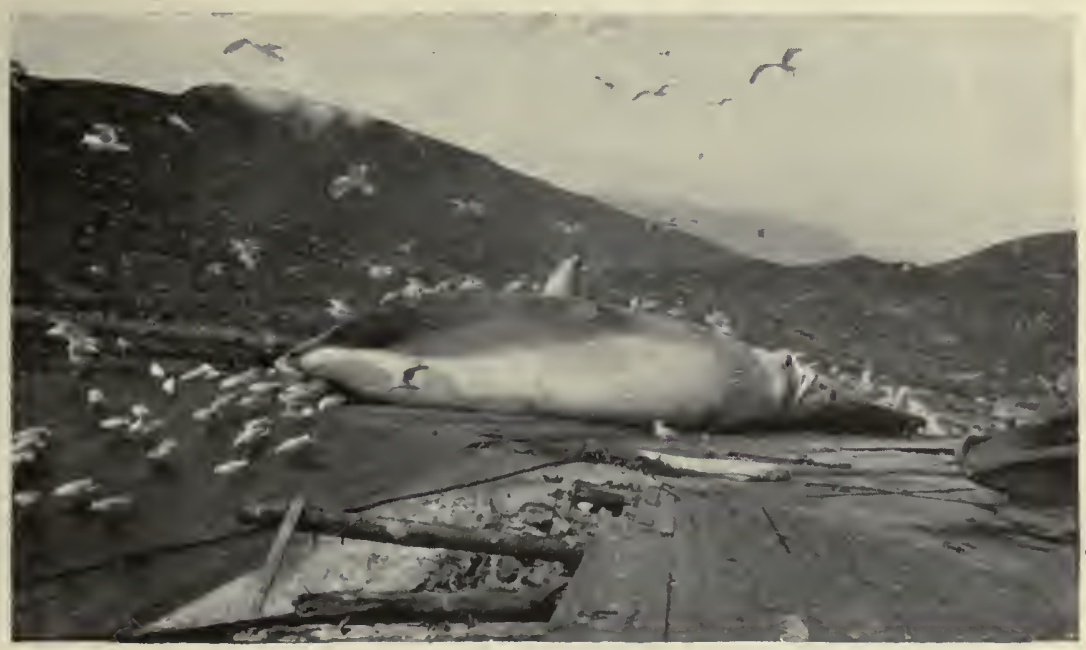

Fin Wha'e landed at the Whaling Station, Harris. 


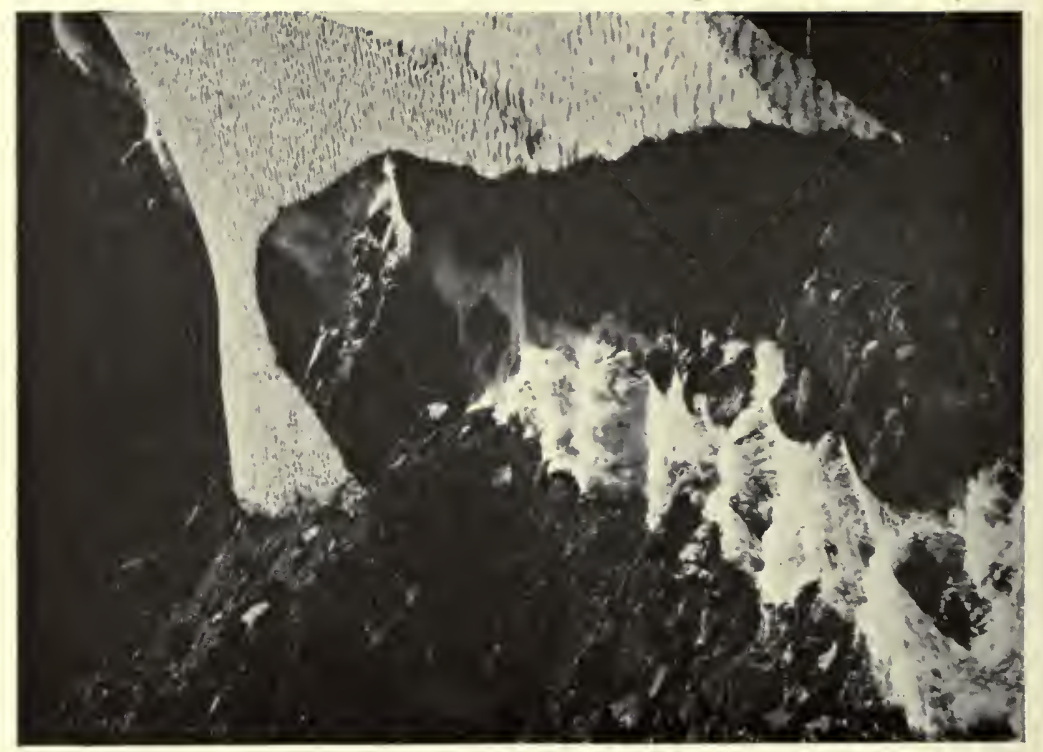

$r$

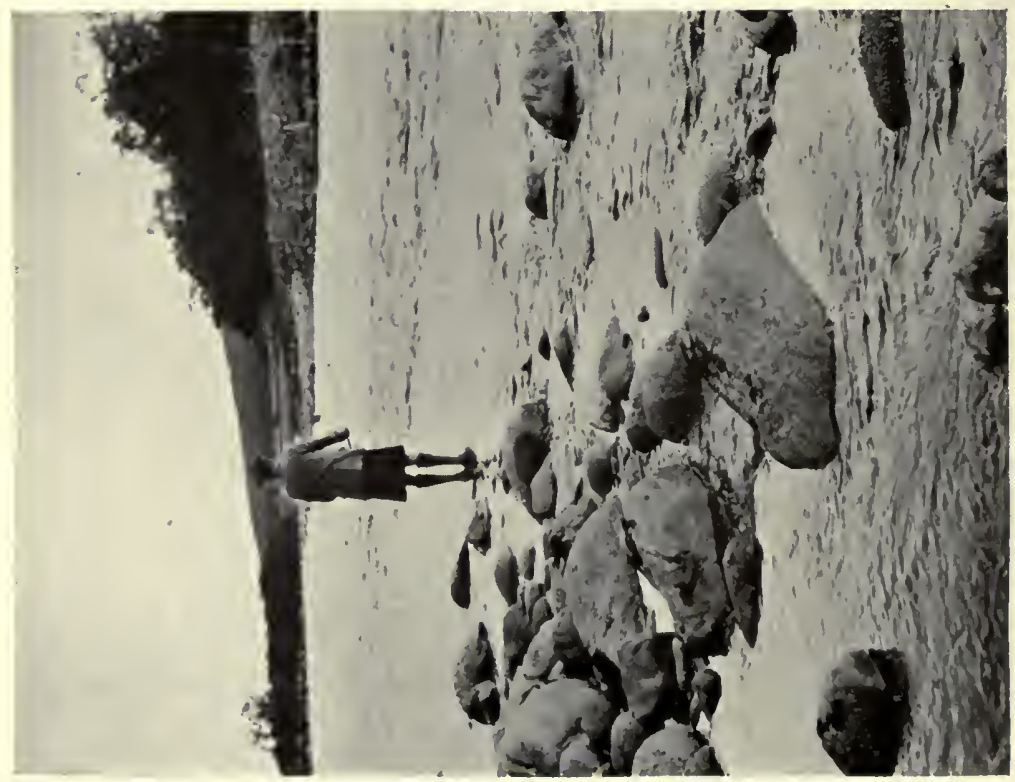

: 


\section{CHAPTER XVIII}

\section{MIDSUMMER AT THE WELLS OF DEE}

I

T has been estimated that in the latitude of the Cairngorm Mountains the snow line is not above 5,000 feet. Thus it is that at the source of the River Dee, on the plateau of Braeriach, at a height of just 4,000 feet above sea level, the season of summer is at the best but a fleeting and precarious one, and snow and frost may prevail here for days on end in every month of the year.

It was on a dull morning without, even on the high ridges, the faintest breath of wind, that a companion and I made our way from Loch Einich up the steep face of Coire Dhondail. Near the head of the corrie were many hinds feeding, and we passed within a yard or two of a hen ptarmigan, with exceptionally beautiful plumage, mothering her covey of chicks. Reaching the top of the corrie, our way led along the banks of the hill-burn known as Allt Choire Dhondail, to where the stream rises near the watershed at a height of just under 4,000 feet. From here to the Wells of Dee is not more than five minutes' walk eastward, a gentle rise bringing one to the watershed between the Dee and Spey, here 4,025 feet above sea level.

By now the sky had cleared, and the sun shone brilliantly, so that hill upon hill could be seen stretching away to the western horizon. Only on Ben Nevis were clouds resting, but even to the westward of this hill did the view extend - to the high hills that rise above Kingairloch. To a lover of the flowers of the high hills the level ground near the Wells of Dee was of peculiar charm. The cushion pink (Silene acaulis) was everywhere in flower. In 


\section{Wanderings of a Naturalist}

some instances the plants were growing on the bare gravel, with which their crimson blossoms contrasted in a very striking manner. Everywhere Salix herbacea, that dwarf willow of the high tops, was making the best of the all too short summer, and its small green leaves and reddish brown flower buds crept prostrate over the windswept ground. Beside the Wells, the ground was still covered by a small and fast decreasing snowfield, and here plant life had not as yet begun to grow. Up to close on the 4,000 feet level we had noticed violets, both blue and white, in blossom, and, quite 3,000 feet above the sea, a cluster of globe flowers, with rich yellow blossoms, formed a pleasing patch of colour amongst the dark rocks.

The Dee has its source from several springs, all lying near each other, and the infant river, here known as the Allt na Garbh Choire, flows along the plateau for a distance of some 600 yards before falling, in cascades, down the steep face of Braeriach to the Garbh Choire beneath. Along its banks the grass grows green and succulent-this is, I think, the highest point in Scotland where grass grows really well -and a couple of hinds were grazing here. A pair of ptarmigan, with newly-hatched young, showed great anxiety at our approach, the hen running round us, feigning injury all the while, and the cock croaking suspiciously. Although, as the result of a June snowfall in the preceding year, a small stock of ptarmigan were on the high ground that spring, the summer was throughout an excellent one for their young broods, and by autumn the stock was again up to the average.

Although the Dee has its source at the great height of 4,000 feet, it nevertheless rises in a slight depression, for just to the north is one of the most westerly spurs of Braeriach, which in the map bears the name Einich Cairn. Then to the south is a like spur, immediately above Horseman's Corrie, which, although not far short of 4,200 feet high, is apparently nameless. Following along the Dee, then, we reached, near the edge of the plateau, a great snowfield, beneath which the 


\section{Midsummer at the Wells of Dee}

river disappeared. It could be seen that some time during the past winter or spring-probably during the melting of the snows-the river had been flowing over, as well as beneath, the snow, for on the latter much gravel was lying, and the snow had been eaten away by the action of the water, so that it now showed a curiously uneven surface. The remains of a cornice of snow still fringed the plateau here, and after emerging from its snow tunnel the Dee, a few yards down the steep rocky face of the Fuar Garbh Choire, again disappeared beneath ice and snow, and did not emerge till near the foot of the rocks.

Across the Garbh Choire, Cairn Toul was beautifully clear. Lochan Uaine, nestling in its north-facing corrie, lay absolutely still-there was not the faintest of airs to ripple its surface. Even at this late season all the corries held much snow, and in the soft light presented a singularly fine appearance. A hen ptarmigan with her brood at the side of the Dee showed the most remarkable solicitude on behalf of her family. She actually flew straight at my head, and when I hastily ducked to avoid the impact, ran round my feet only a few inches away, nor would she move for the space of several minutes. From time to time she uttered a hoarse croakquite unlike the call of the cock-and followed me across the snow till she had seen me well away from the vicinity of her brood, which, as a matter of fact, had not shown themselves once.

From the Dee to the summit cairn of Braeriach the going is very rough; great granite boulders lie everywhere. It is rare to stand on an exposed ridge 4,248 feet above sea level with the air entirely still, but to-day a wonderful peace and quiet pervaded the high tops, and I have never known the hills hold more charm.

Curiously enough, although at the Wells of Dee Silene acaulis was in full bloom, the extra 250 feet from there to the summit seemed to give a much colder climate, for at the latter point-and even here the plants were healthy and numerous 


\section{Wanderings of a' Naturalist}

-the buds were small and undeveloped, and at least ten days later than the plants at 4,000 feet.

Across the Lairig and on the Cairngorm-Ben MacDhui plateau, Lochan Buidhe appeared as though only a stone's throw from us, so clear was the air. Eastward the sky was brighter, and the lochan from its unruffled surface reflected the blue. Around it the hill grasses grew fresh and green, so that the scene here was of great beauty. Even Ben MacDhui itself lost some of its sternness in the soft light, and amongst its many acres of granite scree small patches of fresh grass appeared here and there in unlooked-for places.

Northwards heavy rain was falling just beyond Aviemore, and in Rothiemurchus and Glenmore thin blue smoke was rising where recent forest fires had eaten into the peat and were still smouldering. At the very top of Braeriach a ptarmigan and her brood rose at our feet, the chicks already strong on the wing. The summit cairn of the hill is built only a few feet from where the precipices of Coire Bhrochain drop sheer over 1,000 feet to the depths of the corrie beneath.

Concerning the origin of Coire Bhrochain, I heard from a veteran Gaelic-speaking stalker the following curious tradition.

Coire Bhrochain means the Corrie of the Porridge, and according to this tradition its name was given to it from the fact that on one occasion a drove of cattle, being herded from Inverness-shire to the markets of the south, lost their way in the hills during mist, and falling over the great precipice were dashed to pieces on the rocks below, being so mangled as to appear as porridge after their fall. I give the story for what it is worth, as I have not seen it set down elsewhere, and with the passing of the older generation of stalkers these old traditions are fast dying out. But to me it would seem as though a more likely derivation is to be found from the fact that in the corrie are often white seething vapours, as though the steam from a great bowl of porridge were rising.

Crossing to the northern cairn of Braeriach, a few hundred 


\section{Midsummer at the Wells of Dee}

yards from the summit, we made our way this day to the low ground by the rough and boulder-strewn ridge between Coire Ruadh and Coire Bennaidh. High above us an eagle, coming from the hill-top, shot at great speed towards the Lairig, and in the glen below hinds were grazing. In Coire an Lochan an exceptional amount of snow still remained. Indeed, the western part of the corrie was almost entirely white, and the snow extended to within a few yards of the loch. At the foot of Coire Ruadh there had apparently been more snow than usual, for the heather was still lying flat on the ground, and it seemed doubtful whether it would recover that season. At quite 2,500 feet we passed a Scots pine about two feet high, healthy and sturdy in its shelter amongst the boulders.

Full summer was now come to the hills, and soon the stags would feed up on to the high tops to graze upon the succulent grass. As yet, however, they had not wandered thus far, and except for the ptarmigan and an occasional hind, the tops were given over to the grey mists that shroud them for days on end, and to the winds that, even at this season of midsummer, so often sweep their storm-scarred summits or sigh and eddy across their dark and gloomy precipices. 


\title{
CHAPTER XIX
}

\section{IN HEBRIDEAN WATERS}

\begin{abstract}
A GREY, leaden morning of late summer. For days 1 now the wind has blown fresh from the west, bringing
\end{abstract}

Across Oban Bay there stand the hills of Mull, faint and indistinct, and with driving rain squalls shrouding them from time to time.

It is just after sunrise that the small steamer which carries mails and passengers for the Outer Hebrides casts off from the pier, setting her course north-west for the Sound of Mull and the open sea beyond it. Comparatively sheltered and landlocked as is the first part of the passage, the Atlantic swell is this morning felt even between Kerrara and Lismore, and the rain clouds race past us from the west, while the glass falls steadily. Terns fish daintily in the broken waters, and an Arctic skua makes its way northward with clean-cut and powerful flight. Near Lismore the tide rushes southward with great speed, and here is a rough and confused sea, spelling destruction to any small boat. Mist and rain sweep across from the Mull hills, so that all distant view is obscured, but the old castle of Duart is seen dimly, overlooking the storm-tossed sound, and farther north the Glas Eileanan, or Grey Islands, with their numerous population of terns.

A brief halt at Tobermory, and off the little village of Kilchoan, in Ardnamurchan, and then the small ship sets her course westward, making for the islands of Coll and Tiree. On the rocks about the Ardnamurchan Lighthouse the Atlantic swell breaks with slow and steady rhythm. 


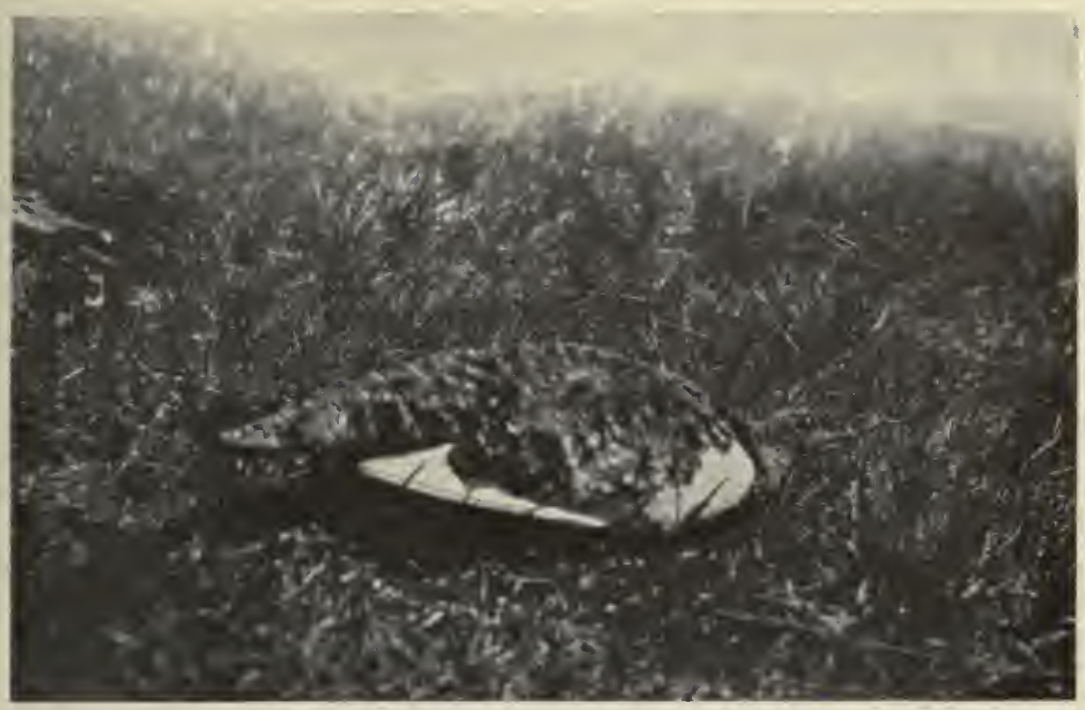

Hen Ptarmigan feigning Wounded and crouching Snake-like.

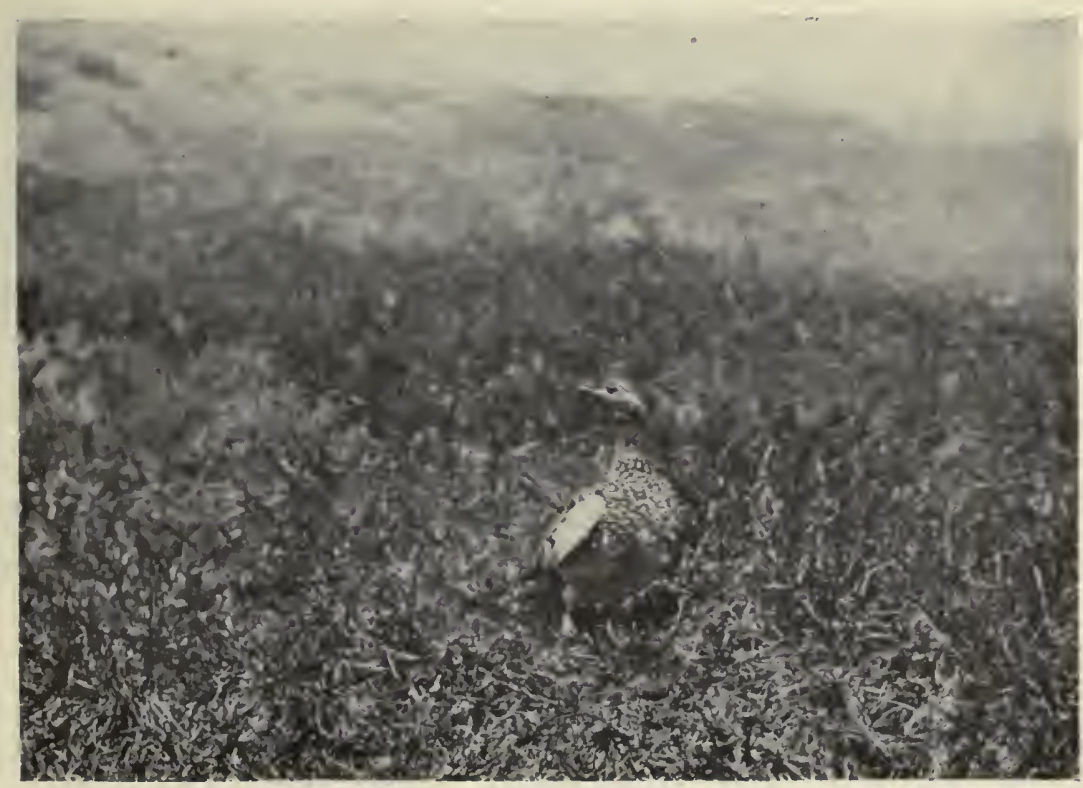

Ptarmigan Listening for her Chicks. 


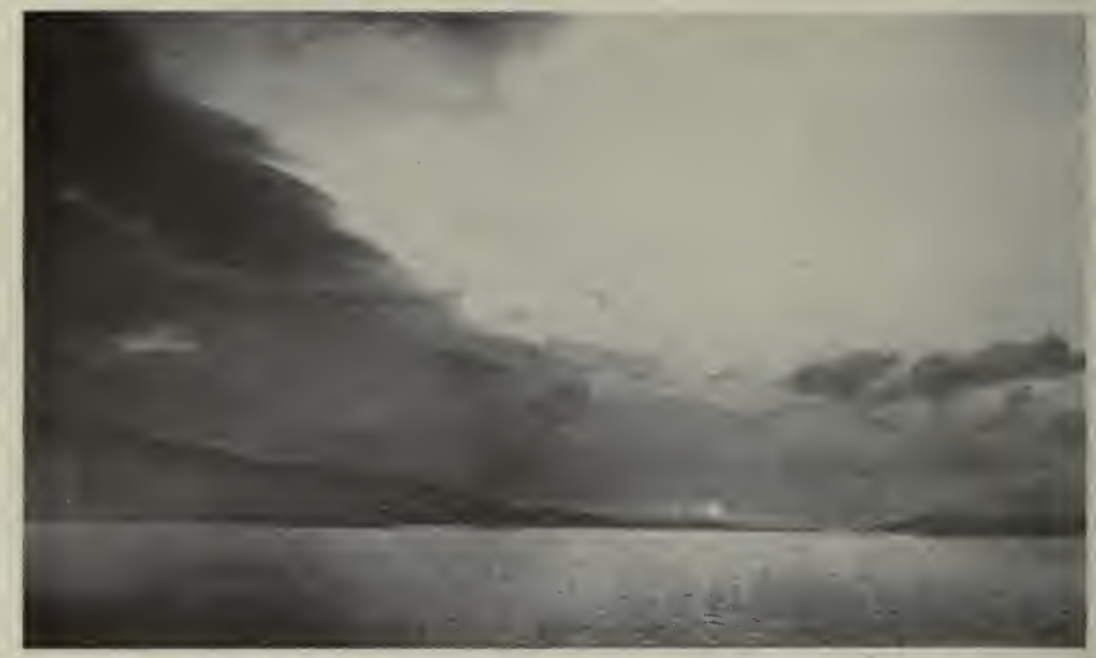

Sun Setting behind the Sound of Mull.

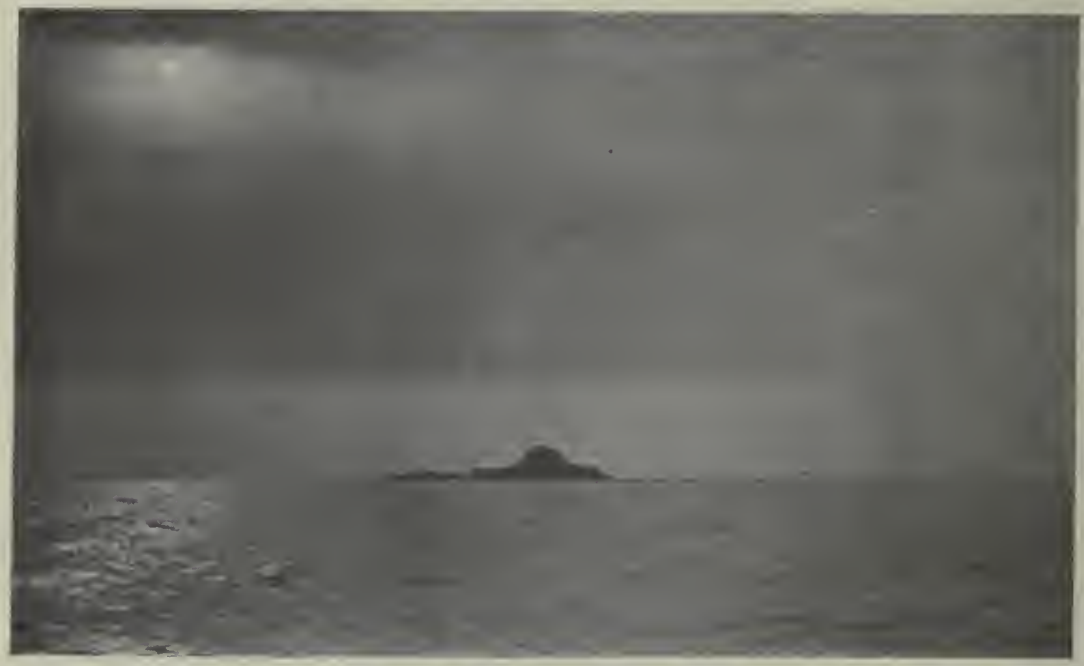

The Hazy Plains of the Atlantic. 


\section{In Hebridean Waters}

Shearwaters dip in graceful flight across our bows, and a fulmar petrel glides with much poetry of motion about the boat, now banking swiftly, now sweeping just above the surface of the ocean, and all the time with scarce a movement of its wings.

At the village of Arinagour, in Coll, a ferry boat meets us, and from here we make for the Island of Tiree.

A short halt at the pier here, and the roughest portion of the day's run is commenced, to Castlebay, on Barra Island, some forty miles to the north-west of Tiree-the course is north-west by north a half north-and the most southerly of the Outer Hebrides.

The tide-swept and rocky Sound of Gunna passed, we at once run into a very heavy Atlantic swell, the great waves rolling past at high speed, and tossing the small steamer here and there, to the discomfiture of the few remaining passengers. For some miles after leaving Tiree a number of gulls follow the boat, receiving doles of bread and biscuits from time to time. The gulls are soon joined by a single solan, then two or three, until finally as many as half a dozen of these birds of powerful flight are following in our wake. To my considerable surprise, these gannets dive for the bread along with the gulls, though they eat it with a certain surprise, as though being, in their opinion, far inferior to the portion of herring which they perhaps expected to find. One solan is sound asleep on the water's surface, with head entirely buried among its feathers. Only when the boat is a few yards away does it awake, receiving the fright of its life and shrieking loudly as it flies hastily away. So soundly do these birds sleep at times that they are caught by the hand from a small boat.

About ten miles off Tiree the seas are heaviest, and on this occasion unusually so for the season of the year. But at length the conical peak of Hecla of Barra shows through the misty air, and gradually we run into quieter waters, reaching Castlebay towards seven o'clock in the evening-the 


\section{Wanderings of a Naturalist}

few passengers on board slowly recovering from the effects of the unusually rough passage. For many days the wild and unsettled weather continues, then at last an extensive anticyclone spreads over the whole of the western islands, the wind drops to a faint breeze, and hill and island stand out once more in the clear sunny air.

Dawn is just breaking, and the Barra hills stand out as black as night against the bright sky as the steamer leaves her moorings at Castlebay. The breeze is from the north this day, and even when we reach the open Atlantic the sea is smooth and without the slightest swell. We pass the herring fleet at the fishing banks, the bright lights of the drifters showing from afar through the clear air. In the early morning sun the Island of Tiree looks at its best, the grass, watered by the heavy rains, of an emerald green, with long white sands in striking contrast in the foreground. From here one can see all the hills of Mull stand out, Ben Mor alone catching the soft mists that so often lie about the fringes of the Atlantic. For a while this conical hill-top stands above the white sea of mist, then, gradually, imperceptibly, the clouds rise until the whole hill is blotted out. Far to the south, and rising from behind Iona, are the hills of Jura, with soft clouds clinging to their slopes. Northward are the hills of Rhum, and near that island the rocky Sgurr of Eigg. How different from the scene a few short days ago, when there was nothing visible save a grey expanse of wild waters, through which in isolation the ship threaded her way. Today, with bright sunshine and a calm sea to cheer them, the passengers in the boat talk animatedly to each other in the Gælic tongue, and a piper paces the deck, his pipes in fine trim and playing many lively marches, strathspeys and reels in quick succession. Around the ship porpoises play, and gannets search the waters with keen eye, now and again abruptly pausing in their flight to dive corkscrew-wise to the sea beneath them.

South-east, and lying between us and Mull, is the group 


\section{In Hebridean Waters}

of the Treshnish Isles, which have already been mentioned in previous chapters. From whatever aspect they may be viewed, these islands are of great charm, and this clear morning they were seen at their best. Outermost of the group, and standing full exposed to the Atlantic seas, is the Dutchman's Cap (Bac Mor). Then, in succession, bearing north-east from it, are the long, grassy Isle of Lunga, with its little hill near the centre; low and heather-clad Fladda, where lobster fishermen make their home during the season of summer; and the minute fortified island of Carn a' Burg, where the chiefs of the Macleans in former days had their stronghold. In even earlier times records prove that as far back as 1249 the island was in the possession of the Norwegians. Under the Macleans, Carn a' Burg successfully repulsed an attack by an English fleet, but the fortress was finally taken and burnt.

Many of the books and records from Iona were at the time deposited on this island as a place of safety, and although the majority of them were probably destroyed, there is a local tradition that certain of these historical documents still lie buried somewhere on the island.

Near Kilchoan the mail-boat passes close to the cliffs of Ardnamurchan, where herons nest, and even at this late date some of the birds can be seen sitting on their nests. Clouds are now obscuring the sun; on the Mull hills the mists are gathering, and when, late in the afternoon, Oban is reached the distant hills show that dark blue appearance foretelling the approach of rain.

For the night the steamer lies at her moorings, but at daybreak she again sets her course for distant Barra, and foul weather as in fair, winter as in summer, she is abroad upon the wide ocean, and unusually heavy must be the storm that prevents her from making the passage between civilization and its remote and misty outposts, the Outer Hebridean Islands. 


\section{CHAPTER XX}

\section{EASAVAL OF SOUTH UIST}

NTANDING at the extreme southern point of South Uist, and overlooking the Sound of Barra, is the hill of Easaval. No imposing mountain is this, but a small, rounded hill with summit no more than 800 feet above the Atlantic; yet from its top in fine, clear weather is a view both wide and varied.

The month of July, 1920, was one of the very worst for many years in the Outer Hebrides, and fine days were few and far between, but my base at Polachar was not more than a couple of miles from the hill, and when at last a day of calm, clear weather came to the islands, I was able to take advantage of it and to visit the hill-top. At first the way led beside the Sound of Barra, where on the shingle ringed plover shepherded their young broods with anxiety, and gannets passed north or south with steady flight, making for their nesting site on distant St. Kilda, or on passage to their far-off fishing grounds in Mull and beyond. Immediately below Easaval is a loch-Loch a' Choire by nameholding many fine trout, unsurpassed in the excellence of their flavour and their fighting qualities, and skirting the loch I made my way to the hill-top along the northerly ridge.

Though the season was late-the date was July 26-a twite or mountain linnet was brooding her four pale-blue eggs, with their dark-brown markings, in the shelter of a heather bank, and not three feet distant a wren left her domed nest containing half-grown young. Once the hen twite was called off her nest by her mate, who fed her-she meanwhile standing with quivering wings-on some choice 


\section{Easaval of South Uist}

morsel he had found. The eggs were near hatching, and both birds flew round anxiously when their nest was approached. Much bog myrtle grew on the hill-side, and in the strong sunshine its fine scent was everywhere on the still air.

The bell heather-Erica cinerea-was already in bloom, but the ling-Calluna vulgaris-would not be at its best for three weeks from this date. Near the hill-top I passed a fine patch of white heather with buds already well formed. Ahead of me a pair of ravens soared tirelessly over the hill. Suddenly the two birds approached each other closely, and I saw sailing in spirals above them a peregrine falcon, who passed on his way over the hill-top, the ravens croaking the while.

But little wind stirred on the hill this summer's day, and the air was exceptionally clear. On the north-western horizon lay St. Kilda, close on sixty miles distant. The island group. was quite distinct : Borreray and Hirta lying close together, and a few miles north-east the great cliffs-Stac Lii-where solans in their thousands nest. North of Easaval, some twelve miles, Ben Mor (2,034 feet), the highest hill in South Uist, was intercepting dark clouds drifting down from the northwest, and the hills of Harris and North Uist were hidden in a rainstorm. Across the Minch lay Skye, with its many hills. MacLeod's Maidens, those flat-topped hills about Dunvegan, were clear and sharp. On the Cuchulain range clouds rested, though the lower slopes of the hills were clear. Rhum was extraordinarily distinct, and on the low-lying island of Canna, a little to the west of it, the long Atlantic swell could, through the glass, be seen breaking. South'ard of Rhum was Eigg, with serrated outline, and bearing more southerly the small island of Muck. Set in the midst of the Minch the tall lighthouse of Heiskeir gleamed in the bright sunlight, a large steamer on a southerly course passing close by on her passage. About here a small rain-squall caught the sun's rays near to the surface of the Minch, throwing back all the colours of the rainbow. It was, perhaps, to the southward that the view was most distinct. All the great 


\section{Wanderings of a Naturalist}

hills of the mainland between Glenelg and Ardnamurchan were clear. Even the lighthouse on Ardnamurchan, some forty miles south-east, could plainly be seen through the glass. The whole Island of Mull, a good fifty miles distant, lay spread out in clear sunshine, with dark thunder-clouds gathering behind it. Ben Mor, Mull, was mist-capped, as it so often is. Near it I could identify Beinn Fada-"the long hill "-and the heights that stand about Gruline.

Then, at the head of Glen Forsa, rose the conical and easily-identified hill, Beinn Talaidh, and a little to the north Beinn Bhearnach, or the "Limpet-shaped hill," standing above Loch Spelve and not a dozen miles from Oban. Dun da Ghaoith, which rises steeply from the deep waters of the Sound of Mull, was distinct, even the cairn on the summit being visible.

The hills of the Ross of Mull stretched away in an uneven outline, and I thought that, near the entrance to Loch Scridain, I could make out Dun I, the one hill of Iona. Between me and Mull lay the long and rugged island of Coll, and beyond the Sound of Gunna the fertile and low-lying island of Tiree, the sun shining on its white sands, and even some of the houses themselves, standing up against the horizon, being visible.

Nearer at hand lay Barra, with its attendant islands, and a few miles out, and making her way to Castlebay, was the Oban mail-boat, with black smoke trailing from her funnel. Out to sea the breeze seemed to die away, and the surface of the Atlantic was unruffled, so that a whale, rising far out to sea in the field of my glass, was easily seen.

Flying south, strings of guillemots and razorbills were making their way to their breeding grounds about Mingulay and Barra Head. Almost at my feet lay the Island of Eriskay, set in the Sound of Barra, its small houses and green and fertile crofts clear in the sunshine. But now to the south mutterings of thunder were heard, and torrential rainstorms formed in various directions, so that the view was obscured. 


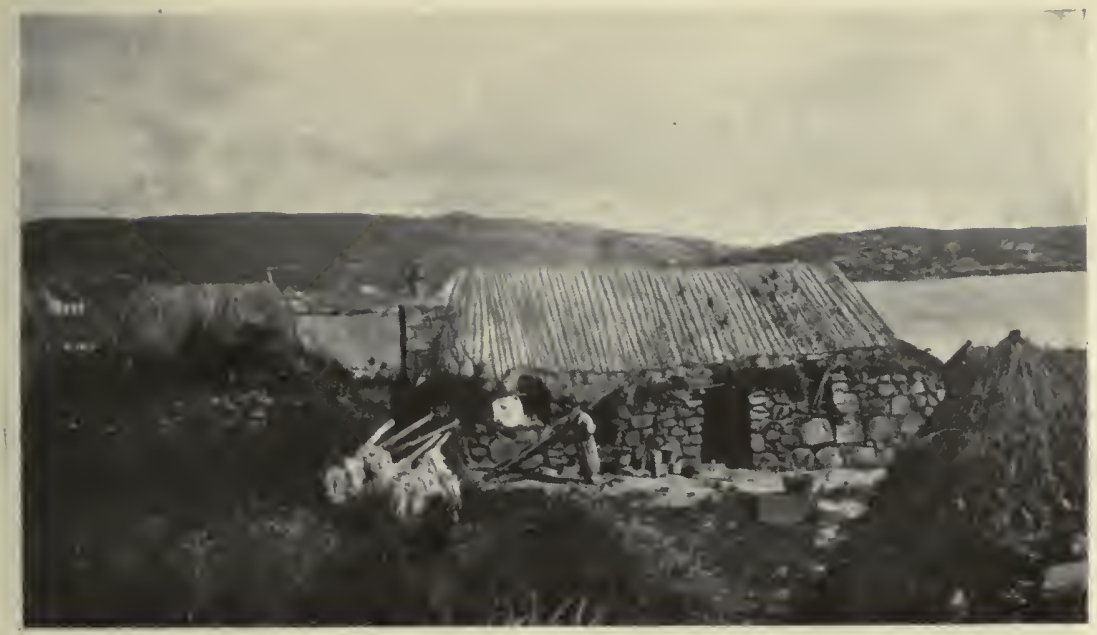

A Hebridean Dwelling House.

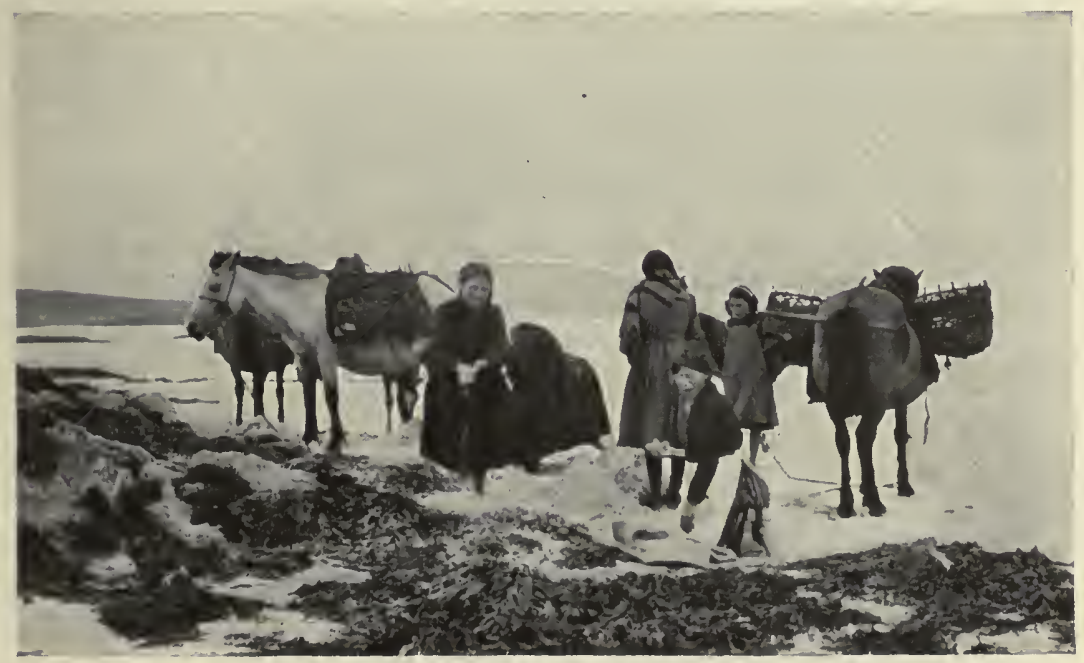

Hebridean Islanders gatherıng Sand to Sprinkle on the Earthen Floors of their Houses. 


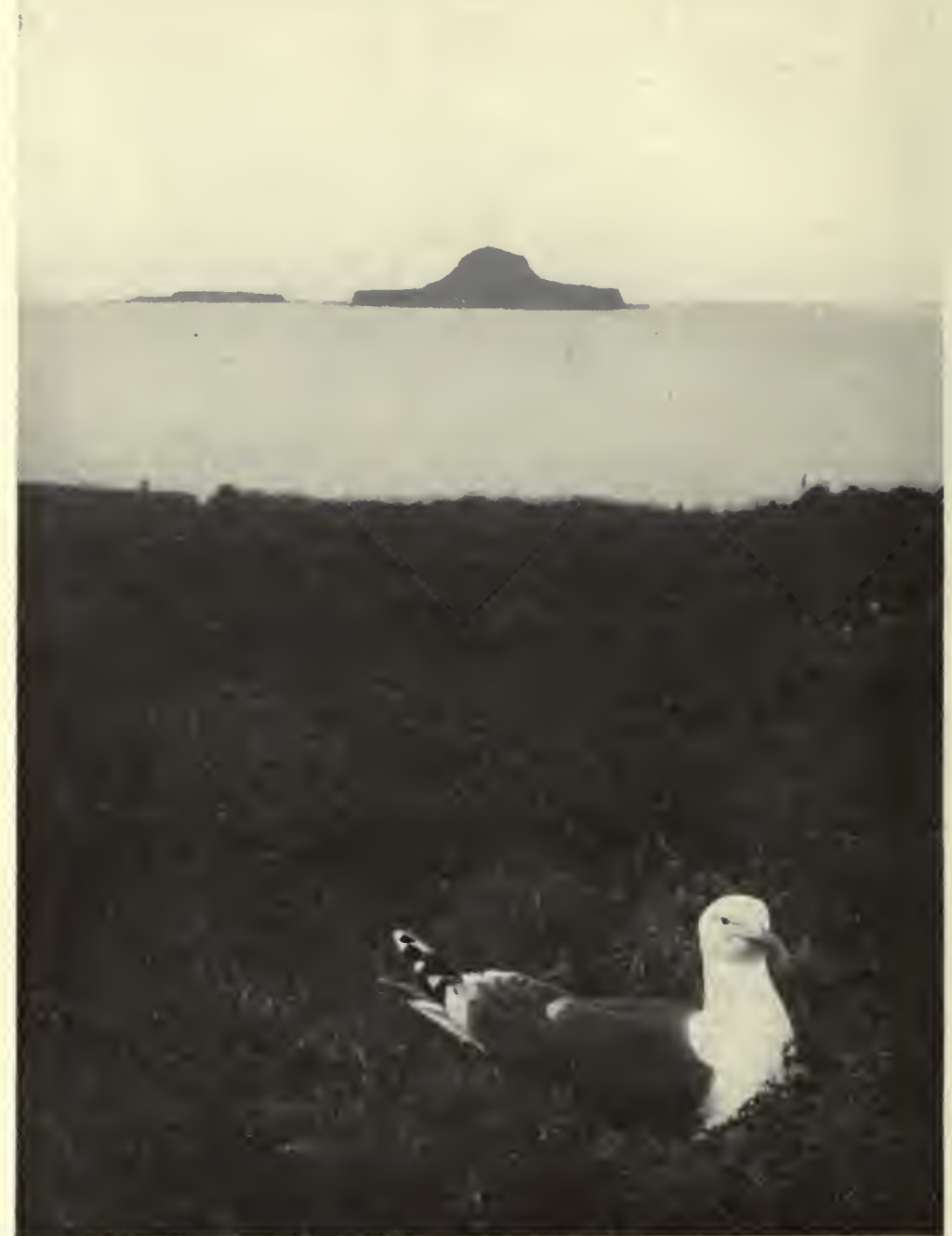

GREATER BLACK-BACKED GULL ON HER NEST.

The Dutchman's Cap in the Distance. 


\section{Easaval of South Uist}

From the north a strong breeze came away, so that in the Sound of Barra white-capped wavelets were hurried before the wind, and the small fishing-boats made heavy weather of it as they set their course for home.

At the foot of the hill a hen harrier passed me, beating the fields methodically and causing great commotion amongst the fussy and self-satisfied corn buntings, though he paid no attention to the birds he put up from the growing crops as he passed.

Grey crows haunted the shore, and a little way out to sea gannets were diving at their fishing. The breeze quietened, and late at night the sun shone on the north-western horizon before dipping beneath the Atlantic near to the lonely island of St. Kilda, where, summer and winter, the long swell breaks on the rocks, and the inhabitants live out their lonely lives, remote from the busy world, and knowing but little of it or its ways. 


\section{CHAPTER XXI}

A FEATIIERED CRIMINAL: THE GREATER BLACK-BACKED GULL

$\mathrm{O}$ $\mathrm{N}$ a small Inner Hebridean island a colony of about thirty pairs of greater black-backed gulls nest. Unlike most of the bird population of the island, which travels south at the coming of autumn, these large gulls remain throughout the year on, or near to, the island of their nesting - for I think that of all the tribe of the gulls, they are the most sedentary in their habits.

During the first fortnight of July, I919, a companion and I made our camp on this uninhabited island, and had good opportunities of studying the life of the gulls.

On the island two colonies of greater black backs nested. One was at the extreme westerly point where, on some level, grassy ground, perhaps ten pairs had their home. The larger colony, however, was on the terraces of a grassy hill near the centre of the island, where about twenty pairs were nesting.

Although the island is uninhabited, frequent visits are paid to it during fine weather by the fishermen of the neighbourhood; indeed, most of the eggs of the first layings are probably taken for food. This would seem to be the only explanation of the fact that as late as the first week of July very few young gulls were to be seen, and a number of the nests still contained eggs. But quite a large proportion of the greater black backs seemed to have had their second layings robbed as well as the first, as, at the time of our visit, these gulls were not nesting, nor had they any full-grown young to tend.

About the open spaces of the Atlantic a breeze from some 


\section{A Feathered Criminal}

quarter almost always prevails, and the great gulls loved to soar in the teeth of the breeze far above the topmost point of the island, which is, at its central part, just under 400 feet above sea level. Soaring thus the gulls would periodically rap out their hoarse and far-carrying call, a cry unlike that of any other of the gull tribe.

Having located a nest in a suitable position for photographing from amongst the colony at the western end of the island-there were here three nests with eggs-we carried our hiding-tent thither late in the evening of July 3 , a beautiful calm summer night. On our way back to our camp in the gathering dusk we disturbed several larks roosting in the tussocky grass-for curiously enough there were a few of these songsters even on this Atlantic outpost-while from the heaps of stones that strewed the shore storm petrels were uttering their purring cries. The next morning we revisited the gulls, but as the first-chosen nest gave no results we moved our hide near to another nest. Next day, finding that this bird had become more or less indifferent to the hide, we moved it closer, setting it up at a distance of about six feet from the eggs. The hide was then carefully camouflaged with pieces of grass and my companion entered it, while I, having walked ostentatiously away, sat down on a knoll two or three hundred yards distant, satisfying myself before my departure that the gull had returned to the nest. Several photographs were taken on this morning, but it was thought inadvisable to disturb the bird unduly on the first day, so, shortly after noon we left her in peace, the hide remaining in position.

On the island a number of bullocks-or stirks, as they are called in Scotland-grazed. These animals usually fed round the hill near the centre of the island, for by judiciously changing their ground they could graze in shelter and comfort whatever the strength and direction of the wind. Very late in the evening of the day on which we had been photo. graphing the black back the wind fell away, and the stirks, tempted by the fine, calm weather, left the shelter of the hill 


\section{Wanderings of a Naturalist}

and fed right out on to the grassy plateau where the colony of gulls were nesting. Through the night, or very early in the morning, the cattle must have discovered the hiding-tent, and with that love of destruction so characteristic of them, proceeded to raze the curious object to the ground. In the morning, on coming in sight of the nesting ground, we were surprised to see nothing of our hide-tent, and on reaching the spot found it flat on the ground and badly knocked about. But a more distressing event-one of the bullocks had been lying actually on the nest, and the two eggs, very near hatching, were hopelessly crushed.

This unfortunate occurrence was a sad blow to us, and we decided that it would be inadvisable to attempt to erect the hiding-tent anywhere on the plateau so long as the cattle were in the vicinity.

Through the glass I could make out a greater black back brooding on her nest half-way up the hill near the middle of the island, and nearly a mile distant. Marking the spot, we repaired and carried off the hide, and on reaching the hill had little difficulty in finding the nest, which contained two eggs, one of them just chipping. From this nest, about 300 feet above sea level, a grand view met the eye this clear and sunny July day. A fresh north-easter ruffled the waters of the Atlantic, and from the sea, sparkling in the sunlight, many islands rose. One saw, away eastwards, the great Island of Mull with its hills, chief among them Ben Mor, over 3,000 feet high. South, Iona lay, with white sands glistening in the sunlight. Westward one saw Tiree, and near it the lighthouse on Skerryvore. North-west and north Barra, Uist, and Skye stood out, all with many hills rising sharply into the sky of deep blue.

The site of this nest seemed such that no cattle would be likely to feed near, so again - and with considerable difficulty, for the ground was rocky-the hiding-tent was placed in position some yards distant from the nest, and this having been done we left the spot in order that the gull might become 


\section{A Feathered Criminal}

familiar with this addition to the normal features of her hillside. The following morning my companion entered the hidirg-tent and, the gull returning with little hesitation, several pictures were secured of her. Next day the nest was again visited, and I entered the hide about ten o'clock.

By now-July 8 -one of the chicks had hatched out and was cheeping vigorously, while its companion, as yet imprisoned in the egg, was tapping at the latter energetically with its bill and cheeping feebly. The difference in the age of the two chicks seemed to show that the gull had commenced to brood immediately after laying the first egg.

The hiding-tent, placed as it was on a sloping hillside, was extremely uncomfortable to sit in. In the front of the tent a small hole was cut in the canvas for the lens of the camera, and two others, one above and one below, to serve as peep-holes. These peep-holes were large enough to peer through with one eye only, and as there was usually a strong draught of air blowing through them into the sunheated interior of the tent, prolonged watching was by no means pleasant. For about five minutes after my companion had left the hide I could hear the gulls calling as they circled overhead. Gradually they quieted down, and the owner of the nest beside the tent flew low, backwards and forwards, over the hide for perhaps five minutes, spying out the land. Then, through one of the peep-holes, I could see her walking leisurely down the grassy ledge towards her nest, and after several pauses she came forward, settling down sedately on to her first-born and the chipping egg. The chick seemed to be a source of interest to her, for she periodically stood up to gaze upon it, subsequently brooding it once more after a careful scrutiny. But when a false alarm excited the colony periodically, the mother bird, on flying off her nest, treated her chick with scant consideration, and as she "kicked off". from her nest in order to launch herself into the air, usually sent her young one flying with a blow from her powerful foot. A Spartan upbringing for one so young!

H

97 


\section{Wanderings of a Naturalist}

On one occasion she picked up a small stone a few yards from the nest, carrying it to beside the latter, when she dropped it. During the time she was brooding the cock stood on guard on a rock near, and whenever a gull flew past croaked a challenge with neck fully outstretched and head depressed. The bird on the nest on one occasion called alsopossibly it was the cock that was brooding at this moment, for it was impossible to distinguish them.

A few weeks previously I had been photographing a particularly nervous golden plover on her nest, and I could not help being impressed by the contrast in the behaviour of the two birds.* The golden plover, during the week I was daily in the hiding-tent, never became used to the slight noise of the shutter, and invariably flew into the air as if shot when this was released. The greater black back, however, even the first time the shutter was fired, betrayed no alarm, merely gazing at the hide in an inquiring manner. The hot sun shining full on the nest troubled her a good deal, and she gasped and panted so that drops of saliva formed at the end of her bill and dripped in a steady stream to the ground. The red blotch on the lower mandible was extremely conspicuous on these occasions. This bright red mark is found on the bills of, I believe, all the family of gulls with the exception of the common gull, and it would be interesting to know what, if any, function it performs.

A close view of a greater black back is something of a shock. On the wing she is, by her wonderful powers of flight, one of the grandest of birds, but watch her from a distance of six feet or so, and then her, or his, criminal look becomes only too evident. The low forehead, with little intelligence or expression, the evil callous countenance, the cold, murderous eye, the singular lack of affection toward the newly-hatched young-there is nothing to admire here. One can easily credit these bird-Bolsheviks with swallowing unsuspecting puffins and shearwaters, as they have been seen to do.

* See Chapter VI, p. 25. 


\section{A Feathered Criminal}

At one nest we found the head and neck of a domestic fowl, which was probably brought from the mainland-at least six miles away. A friend informed me that he had known of a greater black back, kept in captivity, swallowing no fewer than sixteen sparrows at a single meal!

At intervals when I was in the hiding-tent the gull slept peacefully, with head tucked away beneath her feathers. The second chick was slow in hatching, and apparently she lost patience with it, for the egg was found crushed and cold one morning, with the unfortunate chick half-hatched, but dead and stiff. There were no marks of cattle round the nest, so it is difficult to see how they could have been responsible in this instance.

About a hundred yards farther up the hillside was another greater black-backed gull's nest containing three eggs. One morning, from the hiding-tent, my companion watched a fierce battle between two gulls beside this nest, the whole colony being affected by the fight and croaking incessantly as they stood about. No one, however, seemed to think it was their business to interfere. In the afternoon, on visiting this particular nest, I found that the marauding gull had evidently overcome the rightful owner of the eggs, for these were scattered about sucked and broken, while the feathers with which the ground was strewn showed signs of the fray.

Truly a bird that does not hesitate to steal the eggs belonging to its own kind cannot inspire even the most ardent bird lover with feelings of admiration or respect! 


\section{CHAPTER XXII}

\section{MINGULAY OF THE CLIFFS}

\section{$\mathbf{A}^{\mathrm{B}}$}

BOUT ten miles to the south-westward of Barra Island, and set far into the Atlantic, is the lonely and rockgirt island of Mingulay. It is not so many years since a population of some forty persons inhabited the island; now they have emigrated, chiefly to the neighbouring island of Vatersay, which is more accessible, and Mingulay is given over to the countless thousands of sea fowl that make their home there during the time of their nesting.

One August 4 a companion and I sailed out to the island. For a week we had waited for the opportunity of making the passage, but constant storms swept the Atlantic, bringing with them a swell exceptional for the time of year, and it was not until late the preceding night that the wind had moderated. Now with the morning only a light air from the south-east ruffled the waters, but the sky was heavy with watery clouds, and away towards Ardnamurchan and where Mull stood out dimly with mist-capped hills, great banks of ominous grey nimbus clouds lay piled up on the horizon. Our course lay past the island of Muldoanich, where, not so many years ago, the sea eagle still nested, and along the eastern shore of Vatersay, Sandray and Pabbay. Making their flight in single file as is their custom, solans winged their way northward through the sounds between the islands on passage to their nesting cliffs on St. Kilda. Crossing their path, and heading almost all of them for Mingulay, hurried many razorbills and guillemots, flying usually in little companies, now just above the water's surface, now moving rapidly and at a considerable height above 




Forty Winks.

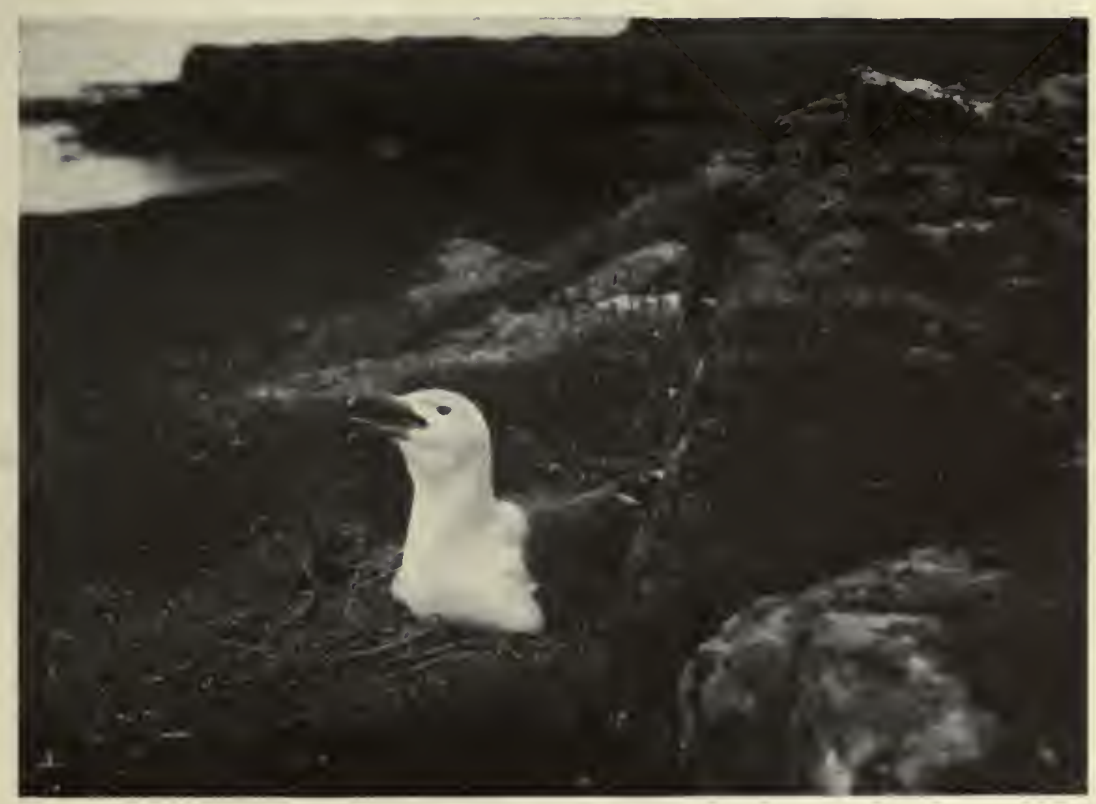

Feeling the Heat.

GREATER BLACK-BACKED GULL. 


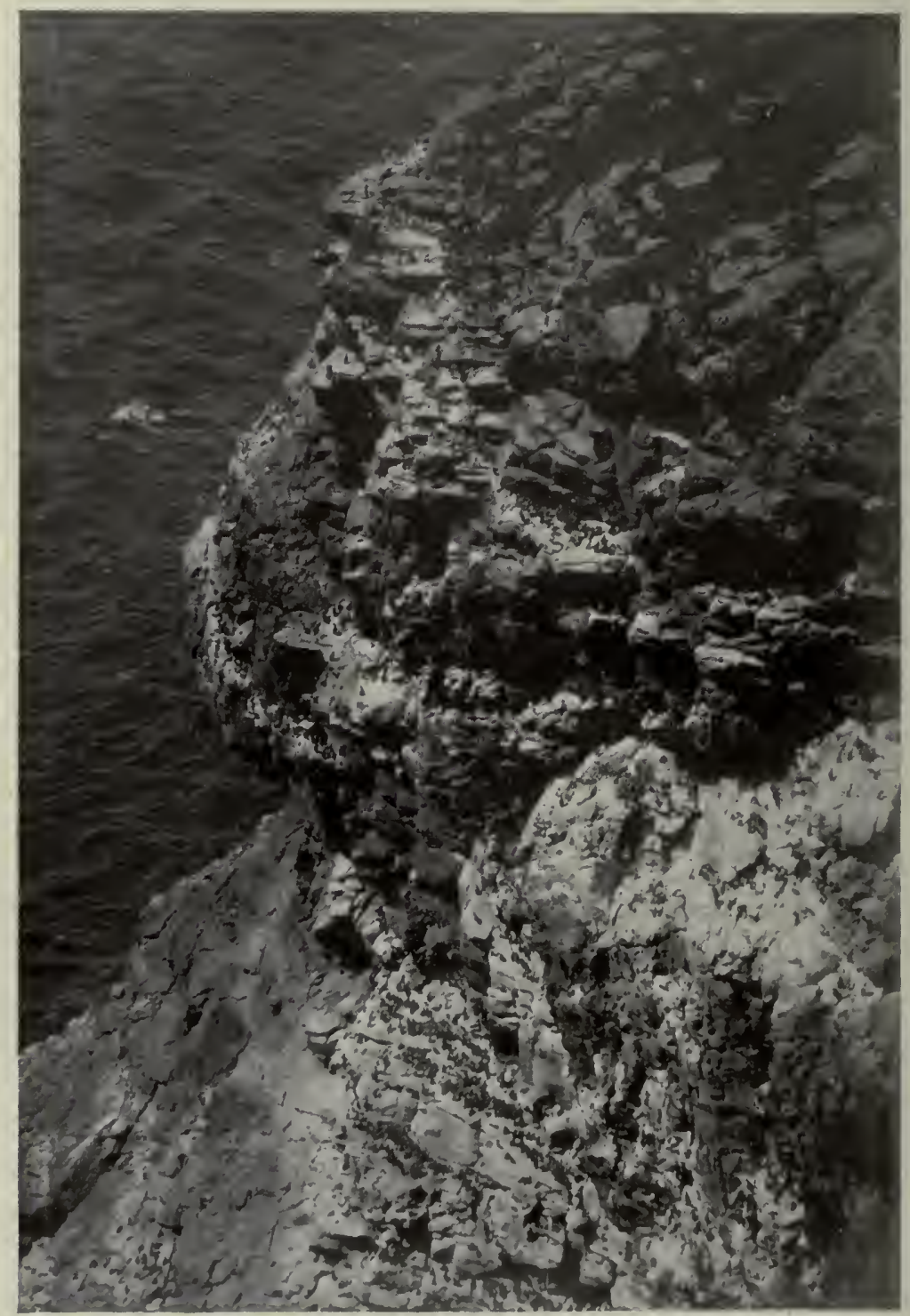

GUILLEMOTS NESTING IN THOUSANDS ON ONE OF THE STACKS OF MINGULAY. 


\section{Mingulay of the Cliffs}

the sea. Many of the birds were carrying fish to their young.

Rain had commenced to fall before Mingulay was reached, and the outlook for our stay on the island was a none too pleasant one, nor did a playful-so we were assured on our return to civilization-bull, which knocked down one of the party while he was wrestling with a heavy camping outfit, pinning him down and incidentally breaking our carefully packed supply of eggs, tend to make matters assume a more rosy prospect.

After a night of mist and rain the next morning was wild and stormy, with half a gale blowing from the north-east, and the great cliffs on the western side of the island were filled with the spirit of the storm. A heavy sea was running, and the long Atlantic rollers dashed themselves against the precipitous rocks, hurling the spray far up their black weather-beaten sides.

So great was the force of the wind, and so insecure and water-logged the top of the cliff, it was impossible to venture near the thousands upon thousands of nesting guillemots and razorbills, but it was interesting to see a peregrine emerge from a high rock and circle overhead, by her hoarse and repeated shrieking showing that even at this late date she was still tending her young. Throughout the day the gale continued, but by next morning-August 6the wind had moderated, and the sun shone brightly.

Although Mingulay is the nesting-ground of such enormous numbers of sea fowl, the rocks are almost everywhere precipitous, and it is in only one or two places that it is possible to climb down to where tue birds are nesting. At one point-immediately below Biulacraig-the rock drops sheer 700 feet, and almost the whole way up the cliff were guillemots and razorbills nesting, the latter birds more numerous at the highest elevations. How do such birds succeed in shepherding their solitary chicks to the surface of the sea, so many feet below them, without accident? The 


\section{Wanderings of a Naturalist}

young of both razorbill and guillemot leave their nestingledges for the water at the age of about ten days-that is, many weeks before they are able to fly. They must, therefore, fall from the ledges to the sea, or be carried by their parents, and stand a very good chance of being killed on some projecting point of the rock, or, even if they reach the water alive, of being crushed against the cliff-foot by the rush of the waves. One could see, floating at the base of the cliffs, the small bodies of several unfortunate chicks which had come to an untimely end, and there seemed to be a great number of the birds still clustering on the ledges which had neither eggs nor young, and which had probably lost the latter. Undoubtedly wild weather must very largely increase the mortality of the chicks, but it would seem as though, even under the most favourable circumstances, this must be considerable. That the season was a late one was shown by the fact that both razorbills and guillemots were in a few cases still brooding their eggs.

Climbing the hill of Hecla on Mingulay, and nearing the summit, one sees sailing in the clear air above, and a little ahead of one, unlooked-for birds, whose soaring powers are quite good, and which one is at first at a loss to identify, when seen above a hillside with no sea apparently near. These are razorbills, hovering and wheeling about and above their nesting ledges on the north face of the hill, and it is only on reaching the watershed that one realizes how sheer the hill drops to the sea on that side. In flight, as in intelligence, the razorbill is far superior to the guillemot. He delights in soaring in the teeth of a stiff breeze or following his mate with slow wing beats-quite unlike his usual rapid flight-above the gully where is his nesting site. The guillemot rarely soars, rarely even flies backward and forward above the nesting-ledge.

The guillemots-perhaps because they nest in such densely crowded colonies-are more quarrelsome than the razorbills, and their harsh and angry shrieks can almost con- 


\section{Mingulay of the Cliffs}

stantly be heard. The young of the razorbill is comparatively quiet; the guillemot's chick is the possessor of a voice of remarkable penetrating power, which even at a great distance can be heard shrilly above the clamour of the adult birds. One of the most crowded colonies of the guillemots was on a precipitous stack-Arnamul by name-separated by only a few yards from the main island on its western side, and where the clustered thousands of birds on the ledges, snow white with guano, were a remarkable sight. On the grassy summit of this stack greater black-backed gulls had nested, though their young by now were in many cases full-fledged and fairly strong on the wing. Already the kittiwakes were gathering in flocks preparatory to the southward migration.

On the afternoon of this day we watched for some time a colony of puffins at the south-west end of the island. A strong breeze blew up the face of the cliff, and the puffins loved to soar past, looking absurdly pleased with themselves and indeed like caricatures of a bird as one might present it on the pantomime stage! In some cases these soaring puffins had their parrot-like bills full of sand eels and, when we remained motionless, they gradually summoned up courage, and then at last dived into their nesting burrows, emerging with great caution a few minutes later, after having fed the solitary youngster. On one occasion a puffin was standing at the entrance to the burrow when a harmless kestrel passed overhead, the puffin thereupon diving into the security of his hole with ludicrous haste. During the afternoon a peregrine flew low across the Atlantic, passing near to the puffin colony, when every single bird hurried out to sea, alighting on the water, where they remained for some time after the enemy had passed.

August 7 was the one really fine day during our stay on the island, though it gave us little sun for the purpose of photography. On that morning, from the high ground of Mingulay, hill and island for many miles lay clear around us. Some thirty miles south, Skerryvore and its lighthouse 


\section{Wanderings of a Naturalist}

rose from the grey waters. Tiree and its hills were dark and clear, and even beyond Tiree the smoke of a steamer was distinct. All the sea birds of Mingulay revelled in the calm air of this isolated day of summer, and it was good to sit and watch them at their family duties. But with afternoon an ominous ring encircled the sun, and before night a freshening southerly breeze and falling glass foretold of more unsettled weather to come. The remaining days of our stay were gloomy and misty, and on August 9, the day on which we left Mingulay, a north-westerly wind, with winter in its breath, was sweeping the cliffs and once more bringing in the great seas, which are rarely quiet about this remote Atlantic island. 


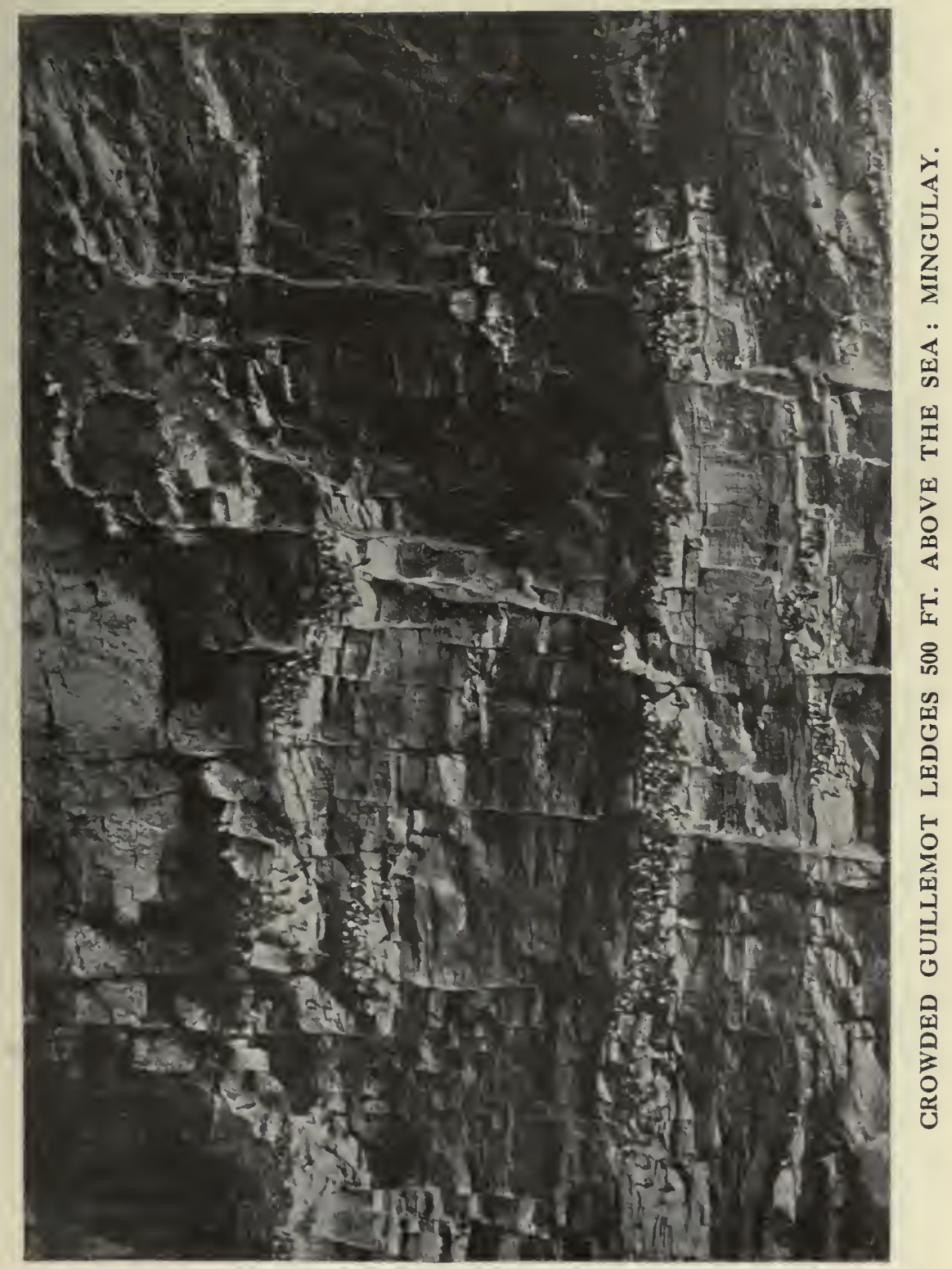




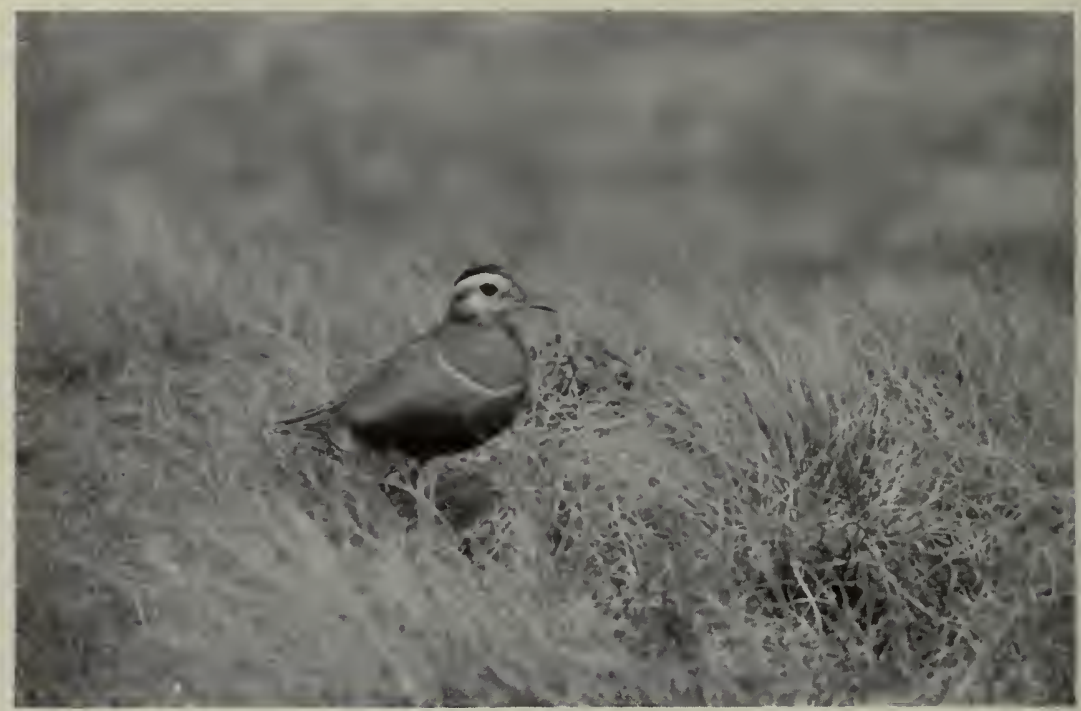

Dotterel approaching a Nest at 3,200 feet above the Sea.

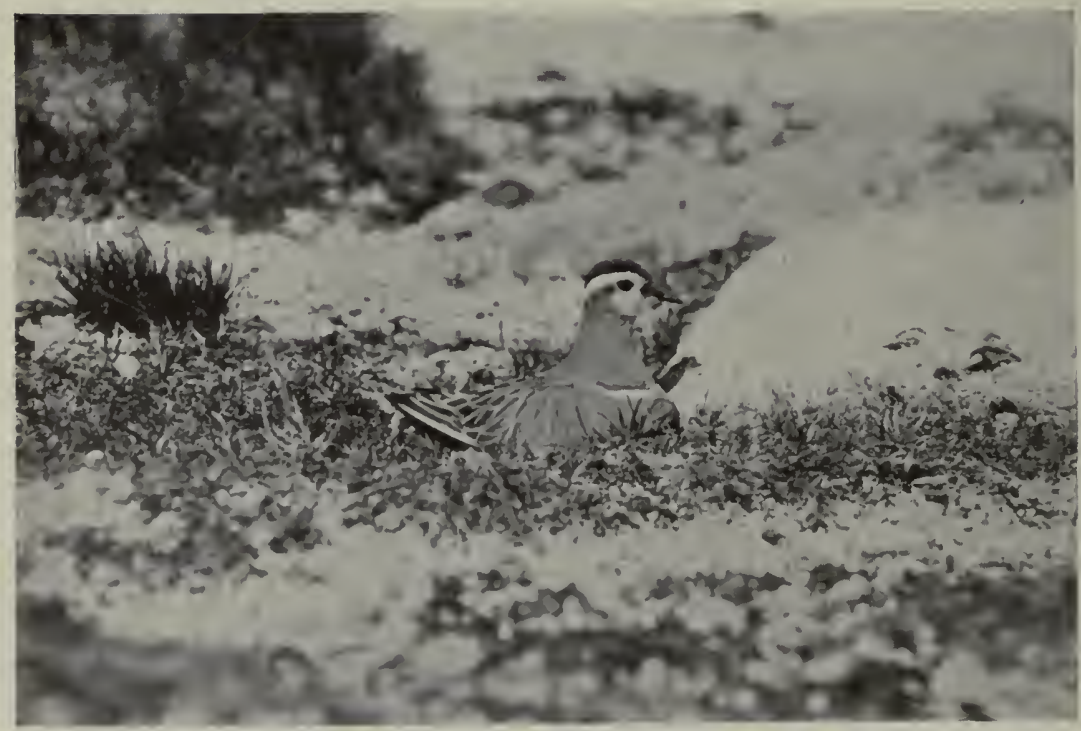

Dotterel on his Nest 3,600 feet above the Sea.

(A big snowfield was within 10 yards of the nest.) 


\section{CHAPTER XXIII}

THE DOTTEREL OF THE HIGH TOPS

M OST fearless, as perhaps most charming, of all birds who have their homes about the high tops is the true dotterel. Compared with that dweller of the coast, the ringed dotterel, which is numerous throughout the British Isles, the bird under notice is rare, for there are certainly fewer than one hundred pairs in all Scotland, and at the outside but half a dozen pairs south of the Border.

So confiding is this graceful wader that in the Gaelic language he is known as "An t-Amadan Mointeach," or "the fool of the peat moss," his absurd tameness seeming to the Highlander to mark him as a bird devoid of sense.

But the dotterel is by no means a fool, although his eggs would be safer from the collectors who are so often on his track were he to borrow some of the wariness and cunning of the golden plover.

The dotterel is without exception the highest-nesting bird in Britain. Wintering far to the south of these islands, he nevertheless chooses as a nesting-ground the topmost slopes of the loftiest hills-expanses of wind-swept ground, too high for even the hardy ptarmigan or the elusive snow bunting.

Personally, I have never come across a dotterel nesting below the 3,000-foot line, and during June, 1920, had under observation a nest almost exactly 4,000 feet above the level of the sea, where, up to the third week in May, the winter's snow remained unbroken. Even during a fortnight in June, when in the glens beneath the air was warm and ro5 


\section{Wanderings of a Naturalist}

the sun shone from a cloudless sky, the wind, often blowing with gale force, was bitterly cold at this dotterel's nestingground.

And little wonder, for a few hundred yards to the south of the nest was a great snowfield filling a wild precipitous corrie, and however warm the day at lower levels, the south wind, blowing straight from off the snow, brought always winter in its breath. Day after day the wind had swept the plateau with gale force, so that the dotterel, when running about the nest in characteristic fashion, had frequently to crouch low, head to wind, with legs wide apart and firmly planted on the ground till the passing of the squall.

Very early on the morning of June ro I first located the birds. They were feeding together on a ridge 4, I00 feet above sea level, and for fully an hour and a half a companion and I watched them feed round and round us, entirely careless of our presence, even at a distance of a few yards.

The morning was a magnificent one. As far as the eye could see, the deep blue fields of the sky extended without a single cloud to dim them. Only the faintest of airs stirred on the hill-top, and even at this height the air was pleasantly warm.

In the case of the dotterel it is the hen bird who is the more brightly coloured of the two, and in this instance-it is an interesting fact that those birds nesting in the far north, or at great heights in this country, are more brightly coloured than their relatives of the south or of the lower groundsboth cock and hen were particularly handsome. From their behaviour we made certain their nest was near, but after a time both birds flew off and we saw nothing further of them that day. I was doubtful whether any bird would nest at so great a height, or in so exposed a situation, and came to the conclusion that this pair had lost their eggs by some mischance when nesting at lower levels, and the fine morning had tempted them to this wild plateau to feed only.

Late in the evening of June 16 we again visited the 106 


\section{The Dotterel of the High Tops}

plateau. Snowfields still lingered here, and little growth was as yet apparent amongst the Alpine plants, although the willow of the high hills-Salix herbacea-was already opening its minute green leaves where the snow had gone. A chill wind blew across from the snow-filled corrie to the south, and in the soft evening light the plateau bore a strangely remote and desolate aspect, but one of a peculiar grandeur.

After searching some likely-looking ground for awhile, with, I must confess, little hope of success, I was delighted to see a dotterel rise just ahead of us and flutter away a few yards in characteristic manner. A short search revealed the nest, a shallow depression scraped out in a tuft of wiry hill grass, and lined with dried leaves-the previous season'sof the Alpine willow. In the nest were three beautifully marked eggs which, on being tested in some running water near, showed that they had been brooded for some days at least.

The following morning we again visited the plateau. Though the sun shone brightly, a strong cold wind swept across from the south. It was hoped on this occasion to set up a hiding-tent, but the force of the wind was such that the idea had to be abandoned.

The dotterel left the nest when we were still some distance away, running rapidly ahead of us. We remained silently near, and it was not long before he-it is, as I have said, the male dotterel who incubates the eggs-came running back in fast spurts, from time to time stopping an instant to pick up a spider or a beetle. The wind was now blowing in fierce squalls, so that he had more than once to stop and hurriedly face the blast, which he did in a half-crouching, tense attitude. On one occasion he twice attempted to pick up a beetle sideways, but each time was blown away and was obliged to turn half about and make a frontal attack on his prey. On the opposite slope his mate was calling from time to time with soft whistling cries, and once she passed over with 


\section{Wanderings of a Naturalist}

swift powerful flight, swaying, however, as the gusts struck her.

From the glens far beneath the smoke from several great fires could be seen rising-for the scorching wind had now blown uninterruptedly for many days, and the heather was dry as tinder.

But now the weather was rapidly changing. Away to the south-west thunder clouds swiftly formed. In a very few minutes the sun was blotted out and the mutterings of thunder were heard, while away westward the hills became dim, and took on a curious copper-coloured appearance.

In the air was that acrid scent that so often accompanies a thunderstorm, and it seemed as though we should have that interesting, though awe-inspiring, experience of a thunderstorm actually in the clouds, which were now touching the plateau.

But the hills were so parched that there was no attraction for the vapours with their moisture, and almost as soon as it had formed the storm passed and the sun shone out once more.

Crossing the plateau there appeared an unlooked-for visitor-a black-headed gull, a bird of the low country. Following the little burn, he soon reached the top of the precipice, when the wind caught him and lifted him vertically a full hundred feet into the air before he recovered his balance.

For a dotterel, the particular bird of which I write was not tame. That is to say, one had to sit not nearer than fifteen feet from the nest to ensure his returning to his eggs without delay. Far warier was he than a dotterel we had just been photographing at a height of 3,000 feet above sea level-that is, at the lowest level at which these birds nest. But then this bird, even for a dotterel, was really absurdly confiding. From the first he showed no fear of us, allowing us to photograph him from a distance of six feet with supreme trustfulness and being obviously annoyed when, by approach108 


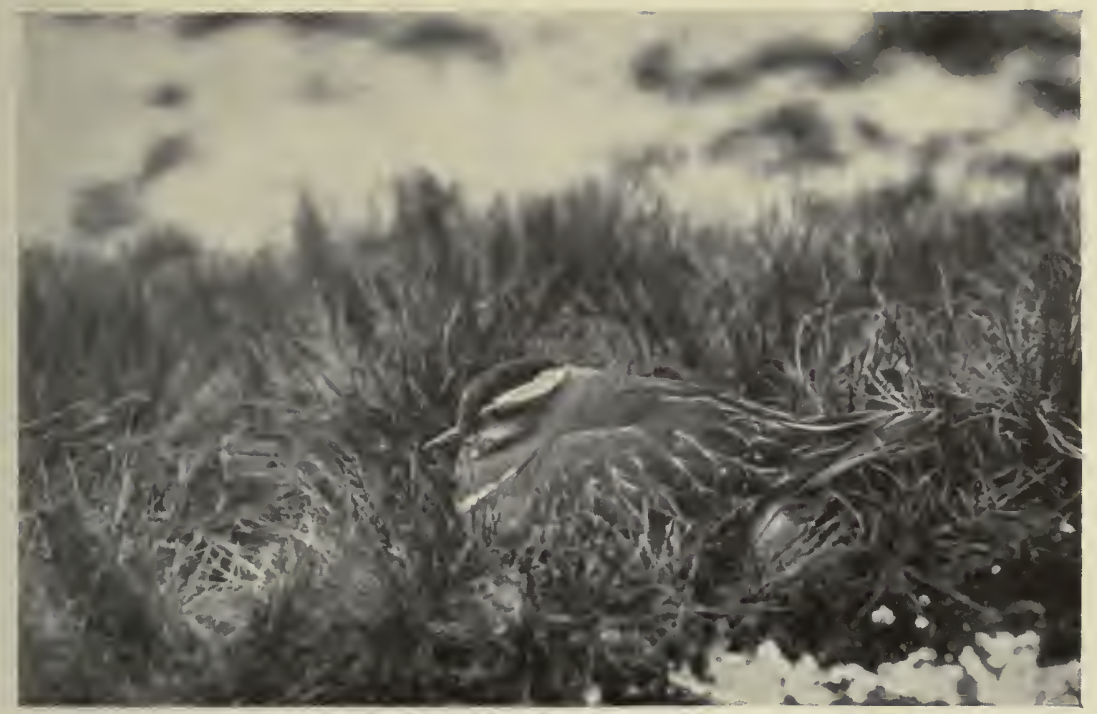

A Dotterel's Nest about $4,000 \mathrm{ft}$. above the Sea : Sleepy and Contented.

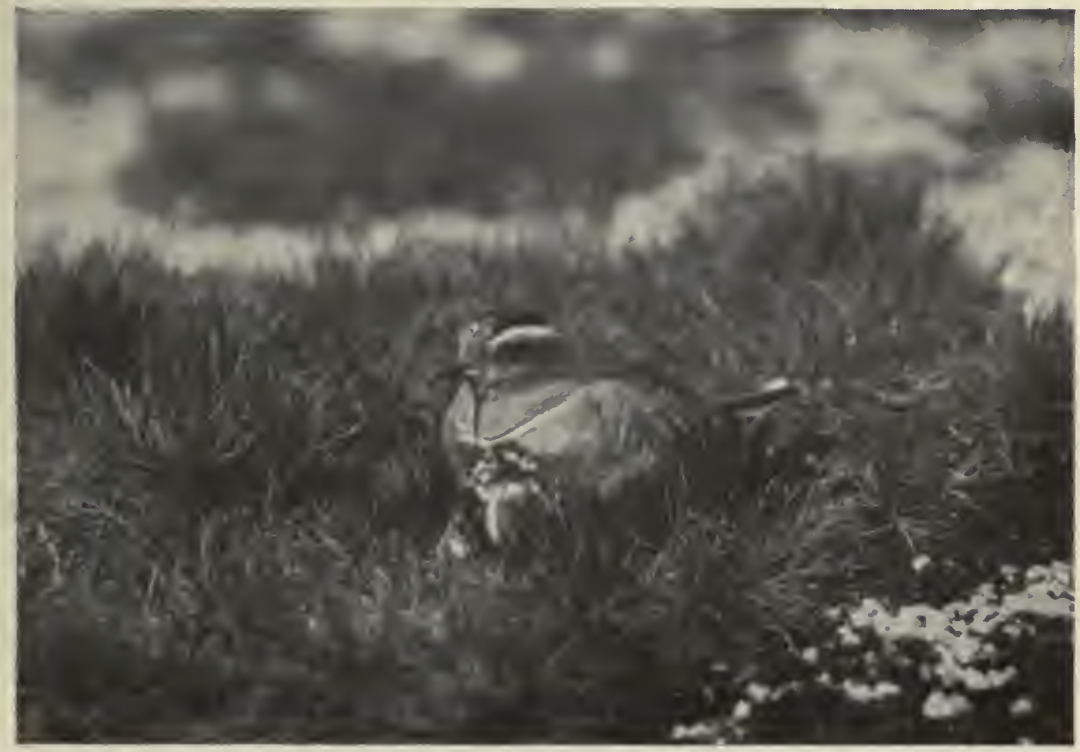

Dotterel: The Baby's first Appearance. 


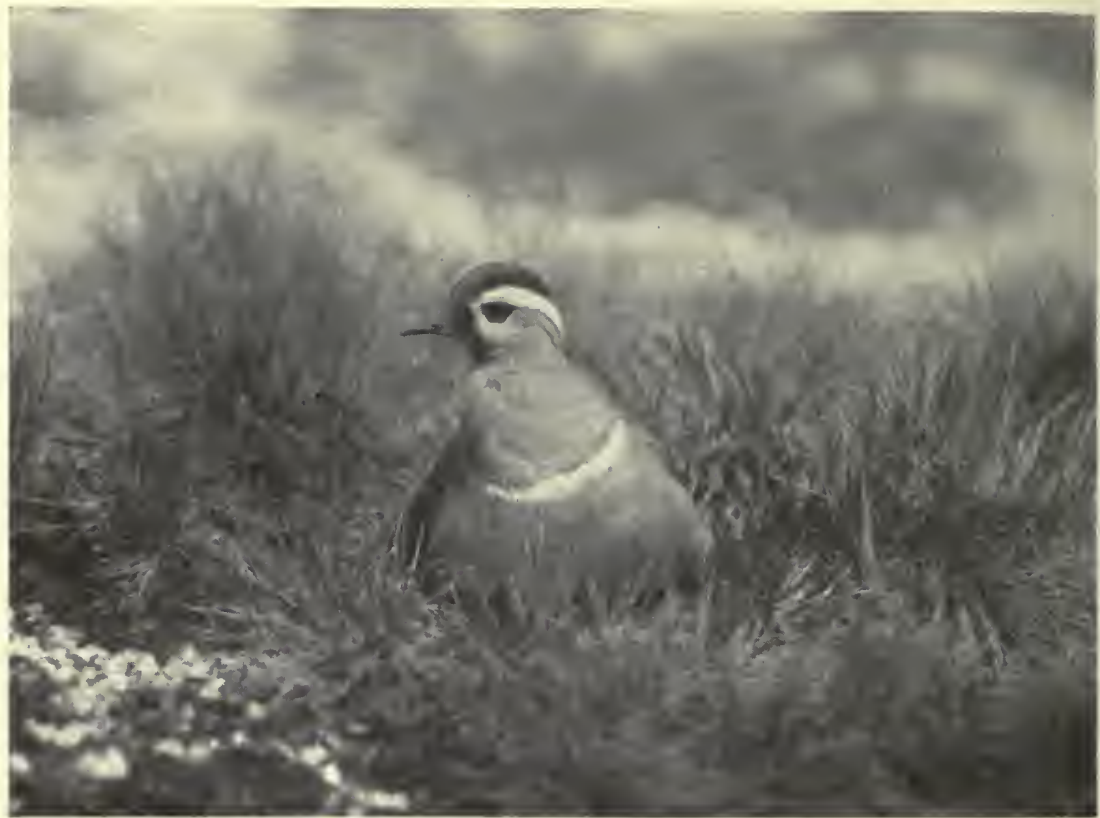

Dotterel brooding the Young at 4,000 $\mathrm{ft}$. above the Sea.

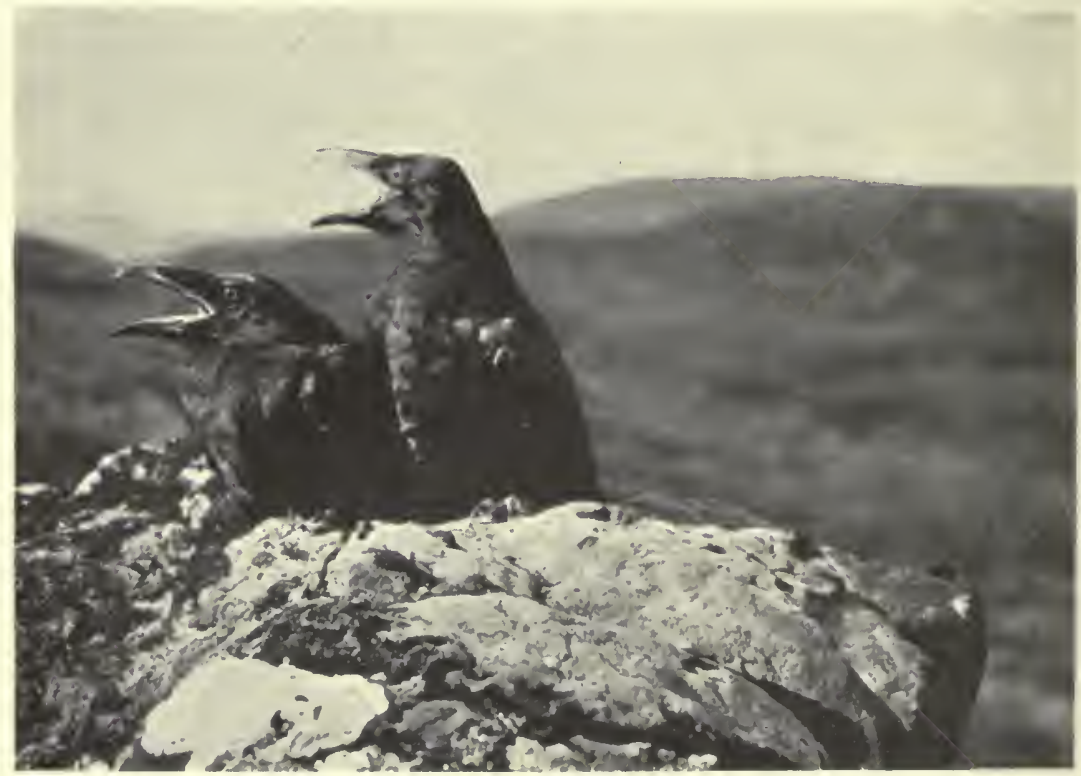

Young Kavens just after Leaving the Nest. 


\section{The Dotterel of the High Tops}

ing to within a foot of him we caused him to rise from his eggs and walk a yard or two away-to wait with obvious impatience for our going.

This nest was liberally lined with lichens. By June 22 the chicks were hatched out and had left the nest. But on this date the nest at 4,000 feet did not show any signs of hatching.

The fine weather had now gone from the hills. A strong southerly wind brought with it white drifting mists, so that it was not easy to locate the nesting-ground.

By now plant life, refreshed by the rains, was at length stirring on the plateau. The cushion pink was everywhere opening its flowers, some of the deepest crimson, others of a pale pink. The grasses were tingeing parts of the plateau a fresh green, good to see as a harbinger of summer.

The dotterel on this day let us approach to within a few yards, when he fluttered off with tail outspread and wings drooping and quivering, all the time calling plaintively. He then disappeared into the mist, but soon returned and flew straight to his eggs, having, I think, lost trace of us in the clouds. We watched him for awhile, and after a little he flew away to a grassy part of the plateau about a hundred yards away, where he was in the habit of feeding.

On this day, at a height of about 3,800 feet, we passed a mother ptarmigan with her brood strong on the wing, and met with another family at the unusually low level-for this hill bird-of 1,800 feet. 'The next occasion on which the nest was visited was on June 24-Midsummer's Day.

Though there was little wind, the air at 4,000 feet was very cold and, unfortunately for the success of photography, the sun shone only for a few minutes, and after three o'clock white mists enveloped the plateau.

For the first time since the nest was discovered it was found possible to set up the hide-the wind, as I mentioned before, had dropped light-and both my companion and I entered it. The hiding-tent was not more than twelve feet from the nest, and though we entered it in full view of 


\section{Wanderings of a Naturalist}

the dotterel he returned without suspicion, and settled down confidently on the nest. He seemed, however, to find the task of hatching out his wife's eggs a dull and wearisome business, and went off to feed no fewer than four times during the three hours we had him under observation. On these excursions he was away about twenty minutes at a time, but on the last occasion he had already been absent from his eggs a full half-hour when we-the light having become too poor for photography-left the plateau for the day. Next morning brought mist and rain to the hill-tops, but towards evening the weather cleared, and the following day saw us once again at the 4,000 -feet level. The nest was reached at 9.45 a.m. (G.M.T.), but the bird was off feeding and the eggs none too warm. The chicks, however, could now be heard tapping vigorously on the walls of their prisons, and a few minutes later Mr. Dotterel returned from his leisured meal, running rapidly over the ground and ignoring the hiding-tent, which we had just erected eight feet from the nest. Even when we both sat inside the hide talking to each other in ordinary tones our presence was unnoticed. The attitude of this obligingly confiding bird seemed, indeed, to be, "Out of sight, out of mind," for he took not the slightest notice of our conversation, and several times dozed on his eggs, as one of the photographs which illustrates this chapter shows.

Once he stood up in the nest and pecked hard at a chipping egg, apparently removing a small piece of the shell. He permitted my companion to approach to within twelve inches of him and then ran off, holding up one wing as though wounded. Once when shamming injury he shrieked aloud, but soon forgot his anxiety and began to feed unconcernedly only a few yards away, returning to the nest within ten minutes and at once falling asleep.

From 9.45 a.m. till 12.15 p.m. he twice went off to feed. The first time he left the nest was at 10.50 a.m., but he was absent only about five minutes. At II.17 he again became 


\section{The Dotterel of the High Tops}

restless and flew off to his favourite feeding-ground about two hundred yards away, returning at 11.32 a.m.

There was a great charm to-day in being on the roof of Scotland. Although the sun was hidden, the air was extraordinarily clear and, a rare thing for these altitudes, not a breath of wind stirred. Over all was a great silence, save for the distant sound of a waterfall in the corrie below and the song of a snow bunting from some neighbouring scree.

For the last time we visited the dotterel at his home amongst the clouds on June 27. The air was still on the plateau, and the sun shone from a deep blue sky. What a magnificent view may be had from this wild country!

From Lochnagar, in the Balmoral forest, away to the conical peaks of the hills about Knoydart, on the Atlantic seaboard, the shape of each hill was clear. Only on the summit of Ben Nevis were clouds resting. Away beyond the Moray Firth could be seen the blue smoke from some moorland or forest fire.

On reaching the nest we found two chicks already hatched, one of them crouching about a foot outside the nest. They were quite dry, and had evidently hatched out during the night or small hours of the morning; the third egg was addled.

The father dotterel appeared very pleased that his monotonous duty had been crowned with success, and whenever the chicks moved under him, purred with a curious though pleasing note. During the course of the morning a pair of dotterel which had apparently lost their eggs fed up close to him. He thereupon flew off the nest with feathers ruffled with anger and fiercely drove away the intruders. By midday both chicks could run actively and made excursions from the nest, returning obediently when called by their father. A little later they left the nest for good.

For some little time the parent bird was unwilling to leave the addled egg. On two or three occasions he returned to it, brooding it for a few seconds and listening intently for the 


\section{Wanderings of a Naturalist}

tapping of a young bird. But the egg was unresponsive, and so he each time hurried back to his two chicks, and, after a while, gave up this brooding as an unprofitable business, and returned to the egg no more. An interesting point was that, although he fed a good deal himself he never made any attempt to feed his young, nor to instruct them 'low to feed. The chicks, nevertheless, actively picked up minute objects, and one swallowed or tried to swallow a blade of grass as long as itself.

An interesting discovery which we made, and which I have never seen chronicled before, was that the young dotterel leave the nest, run actively, and even feed-or at all events pick up things-before their eyes are open! Indeed one of the chicks which we examined in the afternoon had even then, after several hours of wandering, its eyes still almost closed. We had noticed before that they seemed to be uncertain on their feet, frequently falling over, and stumbling against stones, but considering that their eyes at this time were still closed their movements were nothing short of marvellous.

The fine weather was of brief duration. About two o'clock the sun was obscured, and grey clouds drifted in everincreasing masses across the plateau from the south-west.

One by one, the big hills to the westward were blotted out, and the wind blew chill from out the advancing mists.

The dotterel called his two chicks to him, for they were feeling the cold-curiously enough, the hen had never once put in an appearance even on this auspicious occasion when her family first saw the light-and made a charming picture as he brooded them in the shelter of a tiny tuft of green grass, a plant of cushion pink with rich red flowers blooming profusely only a few feet from him.

And so we left him, wishing him well with his family. cares in that wild snow-splashed country of the high hills and dark lochans, where is the home of the mists and of the four winds, and where the foot of man but rarely treads. 


\section{CHAPTER XXIV}

\section{A HEBRIDEAN ISLAND AND ITS BIRDS}

WAY to the west of the Isle of Mull-that romantic land of hill and glen-and set in the tireless waters of the broad Atlantic is the island of which I write.

In olden days a crofter and his family had their home here and eked out a precarious existence from their small croft and the fishing. But for many years now the island has been deserted and is given over to the sea birds and to the tribe of the seals. Lying as it does full open to the south-west where the nearest land is the far-distant American coast, the island stands, a diminutive barrier, against the force of the Atlantic swell which, during the season of storms, sweeps the smooth-worn rocks and thunders on the outlying reefs for weeks on end. But with the coming of February, though the storms may rage still with great violence, the air is laden with a curious intangible essence-the forerunner of the Spirit of Spring.

First of all to respond to this impulse is the pair of dark ravens that have their home on the island. Before February is out the new nest is complete-or maybe, the birds content themselves with repairing the nest they occupied the previous season-and if the spring be an early one the hen is brooding on her clutch of greenish mottled eggs by the first days of March. Most hardy of birds is the raven. No snowfall is sufficiently severe to compel her to desert her eggs; she broods through a blizzard undismayed.

But on these islands of the Atlantic snow rarely lies, and the raven is able to hatch out her brood undisturbed by ice and snow, and secure from the unwelcome attentions of game- 


\section{Wanderings of a Naturalist}

keepers who would give these birds short shrift were they to extend their range to the grouse moors of the mainland.

During these months of early spring the ravens have few bird companions on the island-they share it with a pair of peregrine falcons, a few of those sea birds of sinister reputation, the greater black-backed gull, and many barnacle geese.

At times the peregrines nest on the island, but more often they lay their eggs and-should all go well with them-rear their young in the rocky hill face of a sister island a couple of miles distant. The eyrie is quite accessible, and I remember on one occasion approaching the hollow in which the nest was situated and actually showing my face at the entrance before the brooding falcon was aware that anything was amiss!

On seeing the sudden apparition not more than four feet from her the peregrine stood, petrified with fear, beside her eggs, nor could she summon up sufficient courage to fly out until I had withdrawn my head from view. The season of the nesting of the peregrine falls, as a rule, early in April, and even by this date the raven should have hatched out her brood.

A pair of buzzards nest on the island, and not far from their nesting-ledge a pair of grey crows, birds which can here exercise their egg-sucking propensities to the full.

Till the coming of May, then, the island is peopled with few birds, and there is here comparative silence should a visitor land from a boat on a sunny morning of April. But with the first days of May there arrive at this sea-girt isle a multitude of feathered people, so that the island is quiet no longer but throbbing with life and activicy. Here may now be seen companies of intelligent razorbills, and in greater numbers, guillemots of refined though foolish aspect. But the bird that frequents the island in greatest numbers is the puffin.

This quaint bird is present here during the nesting season, literally in thousands, and the surface of the ocean 


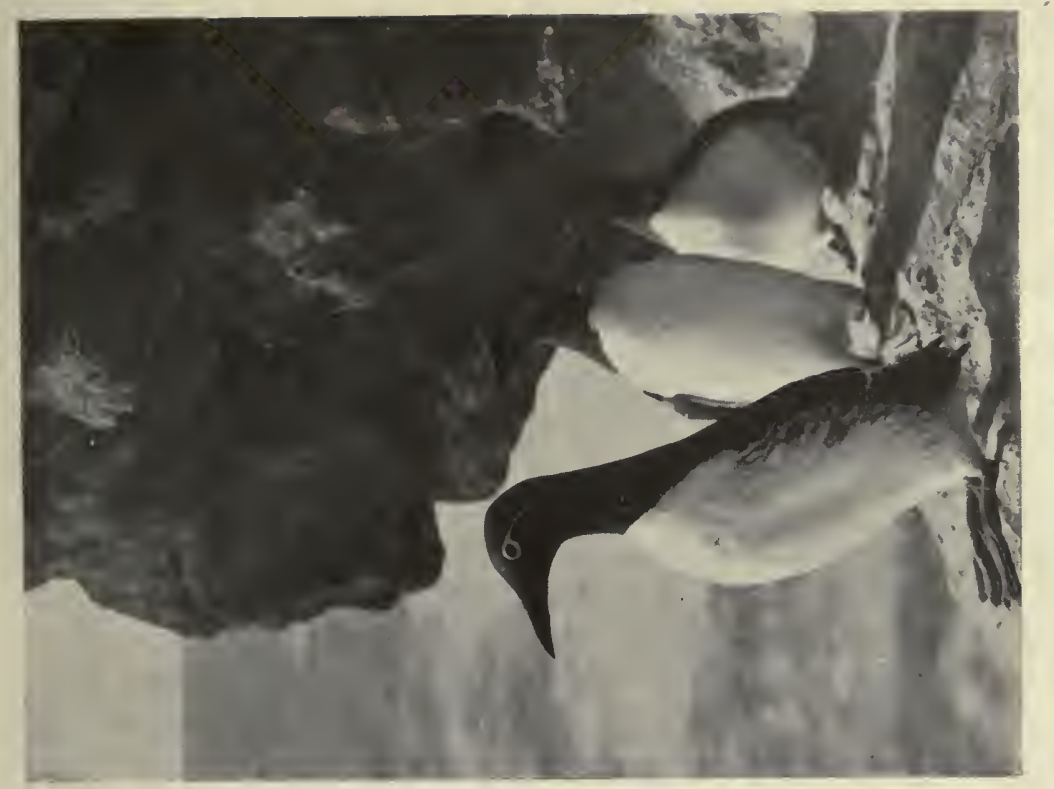

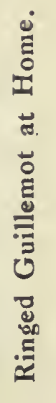

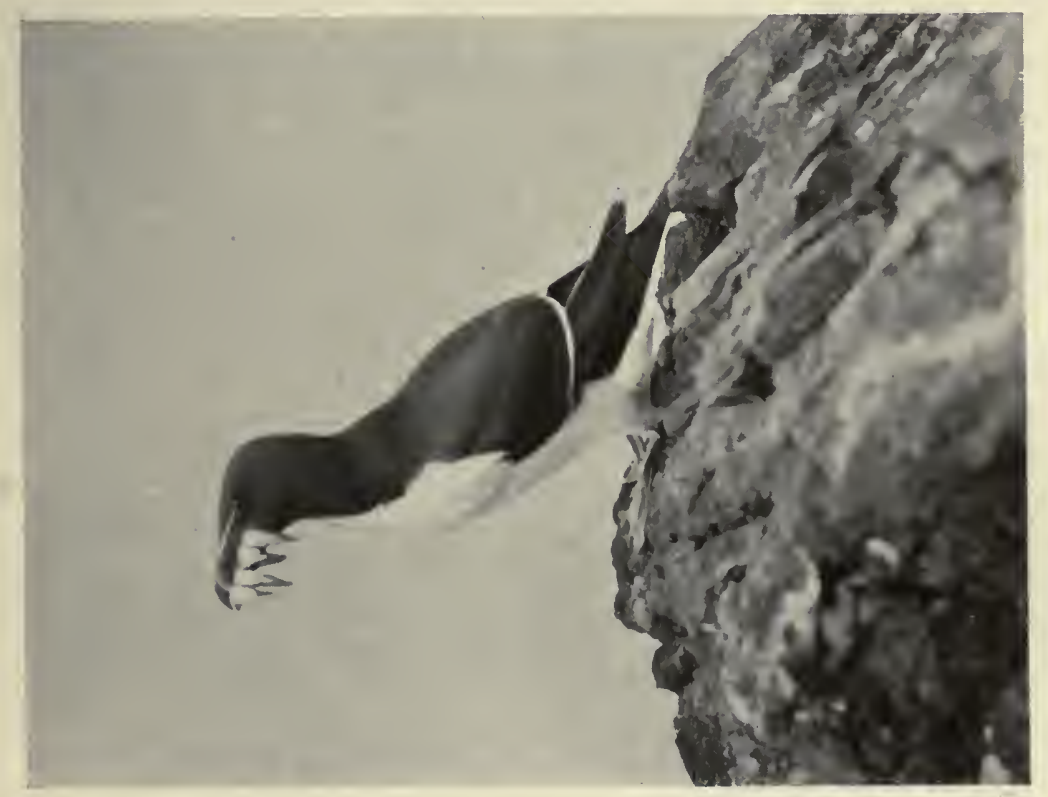

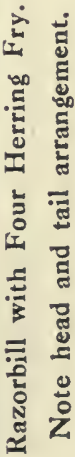




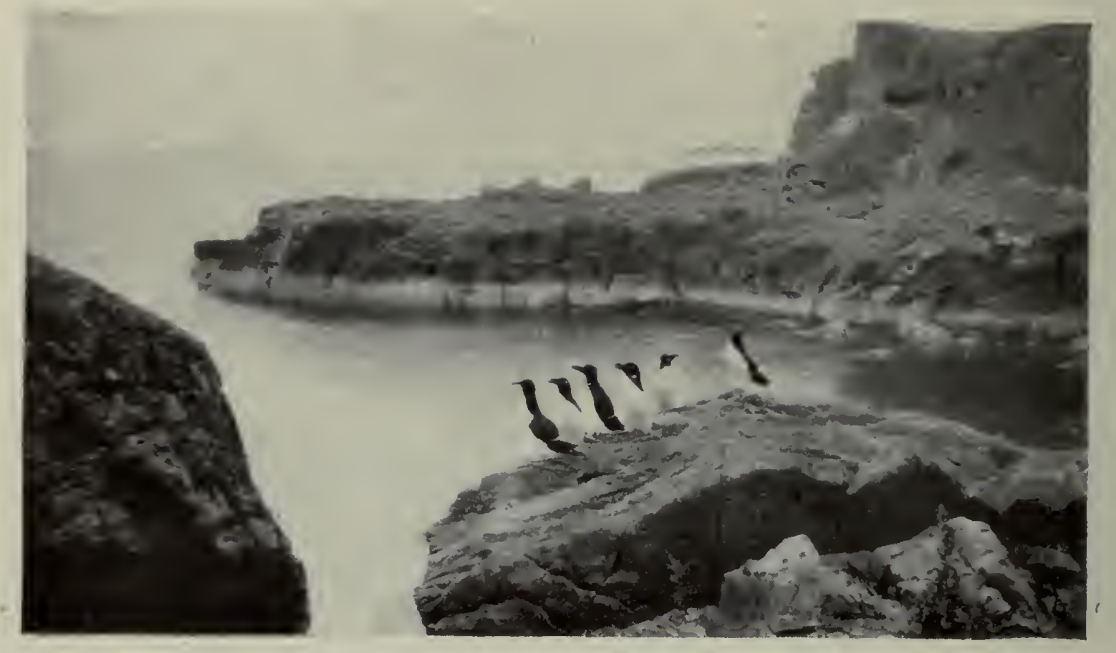

Razorbills in Conclave.

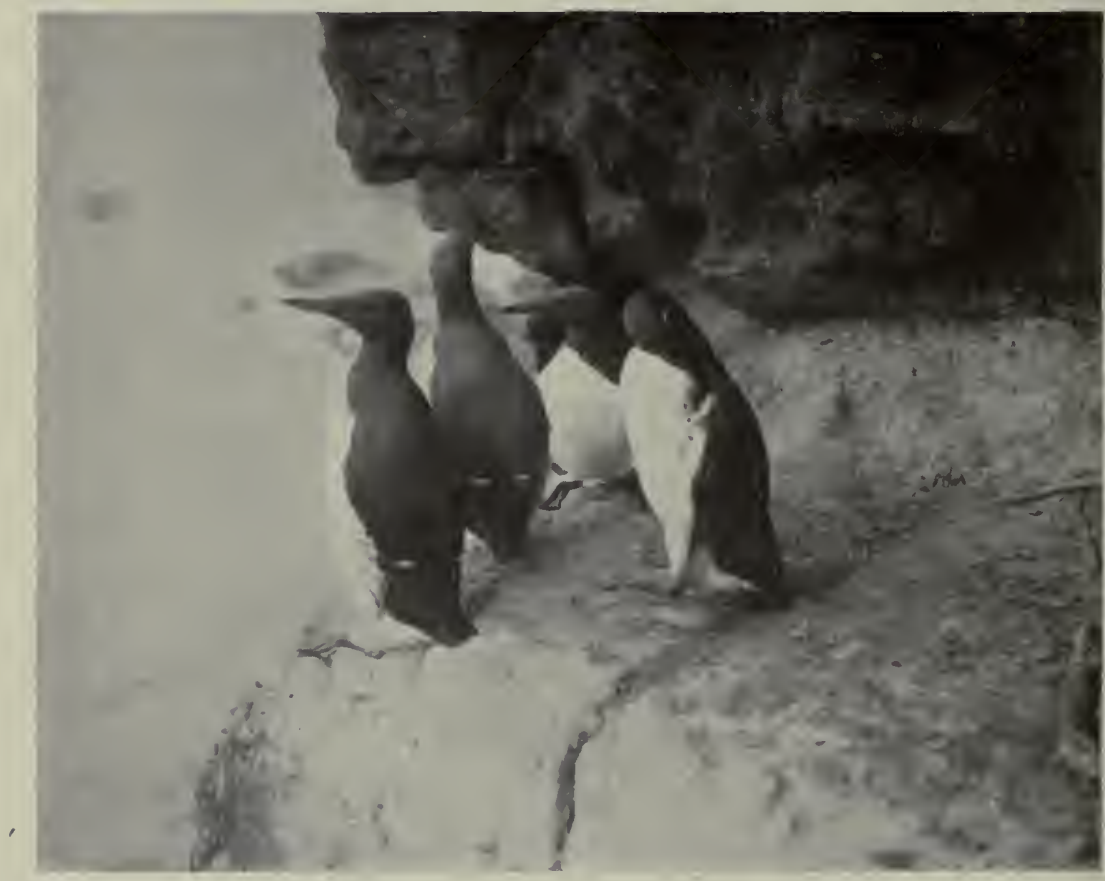

Guillemots: A Leisured Toilet. 


\section{A Hebridean Island and its Birds}

is at times darkened by them as they swim and bathe themselves of a summer morning. Most consequential of birds is the puffin.

He always seems to me to resemble a dignified and respectable club-man-unruffled, unperturbed, and taking life, which he finds a pleasant thing, with rare philosophy and calm. But for all that, life to the puffin is full of dangers. Greater black-backed gulls at times lie in wait for him at the entrance to his nesting-burrow and pounce on the luckless bird as he emerges, either swallowing him whole or-a more terrible fate-disembowelling him, and having devoured the entrails leaving the victim, still alive, to perish miserably.

With the coming of May there arrive at their nestingcliffs many graceful kittiwakes, most charming and contented of all gulls. In the kittiwake there seems implanted a curiously strong love for its nest. For weeks before they have commenced to lay the birds sit or stand contentedly upon the platforms of the nests of previous seasons, and likewise in late summer, when the young have left the nest, or when, perhaps, some misfortune has robbed the kittiwakes of their eggs or brood, they still haunt their nest, standing, the pair of them, for hours at their home with every sign of happiness and contentment.

To the island, before May is many days old, there also come many lesser black-backed gulls. Unlike their larger relatives-the greater black backs-these gulls are summer visitors only to the Hebridean Islands, and with the approach of autumn make their way to more southerly and less stormswept latitudes.

On the higher slopes of the island Manx shearwaters have their home, choosing as their nesting-sites rabbit burrows, where they remain in darkness during the hours of daylight and emerge only after dusk. It has always seemed to me curious that this bird should be entirely of nocturnal habits while at its nesting-site, while at sea it may be observed 


\section{Wanderings of a Naturalist}

flying actively with graceful and charming flight even on days of most brilliant sunshine. Yet one may time after time visit an island on which thousands of these shearwaters are nesting and yet not see a single one till over an hour after sunset.

The last summer visitor to arrive at the island is perhaps the most charming and interesting of them all.

Less than a swallow in size is this small bird of the ocean, and so frail that it is hard to realize how it is able to face the Atlantic storms of winter. To this small wanderer the name storm petrel has been given from the fact that its appearance to the mariner presages a storm or heavy weather.

The word petrel is, I believe, derived from the bird's habit of fluttering down to the surface of the ocean for an instant or two and skimming the waves with drooping feet just touching the sea-and thus, like St. Peter of old, walking on the water.

It is not until the very end of June, when full summer is come to the island, and when no night in these northerly latitudes falls on the ocean, that the storm petrel comes in from the immense tracts of the Atlantic. Here it has spent the winter and spring, hundreds of miles from the nearest land, and riding out the storms which, day after day, for many weeks on end sweep the surface of the sea. The wing power of this little petrel must be quite untiring, for there must be many days and nights when the Atlantic is too storm-tossed for it to alight on the waters for more than a minute or two at a time. Thus throughout the long and dark December nights and short hours of misty daylight the storm petrel must wheel continuously in flight, skimming the great waves and without a moment's respite battling with the storm.

How during such stormy spells can the small traveller obtain sleep? It would seem as though it were compelled to forgo all rest for many days at a time. That not infrequently it is exhausted by the gales is apparent from the fact that not a winter passes but a few of the birds, tired I 6 


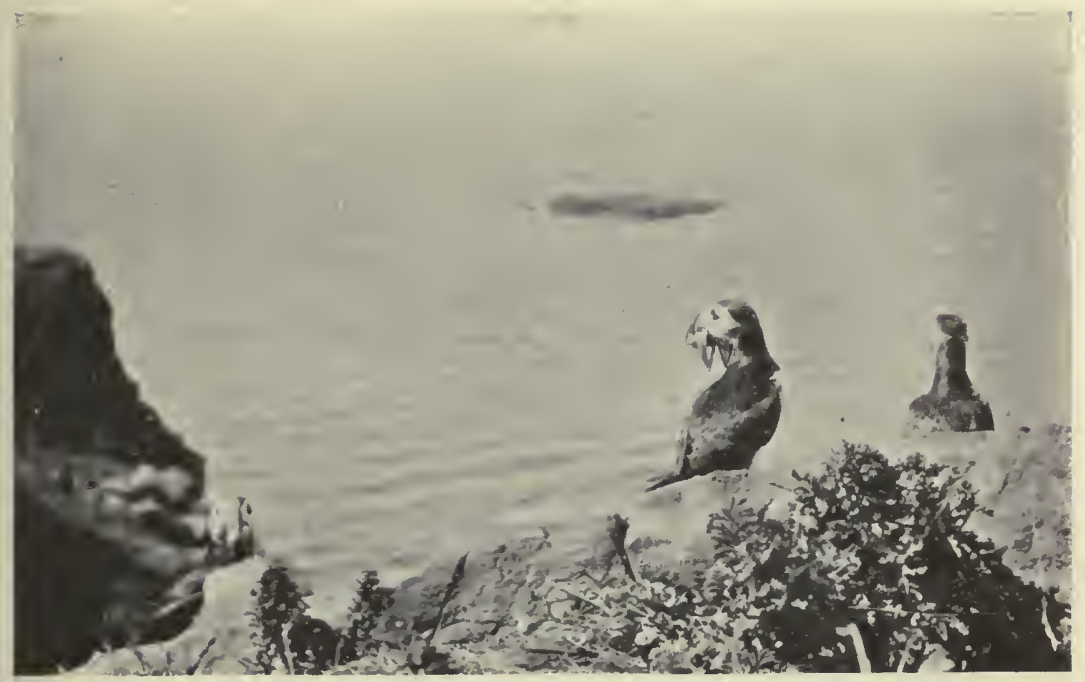

Puffins with Sand Eels.

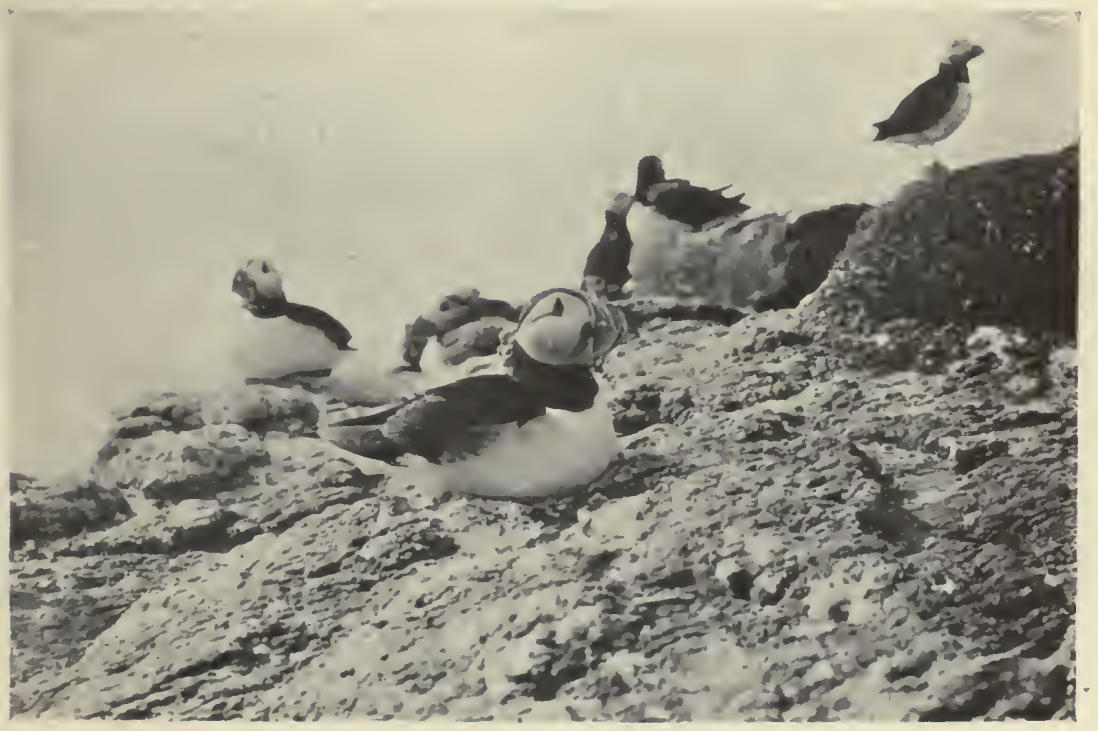

Puffins : Somewhat Weary. 


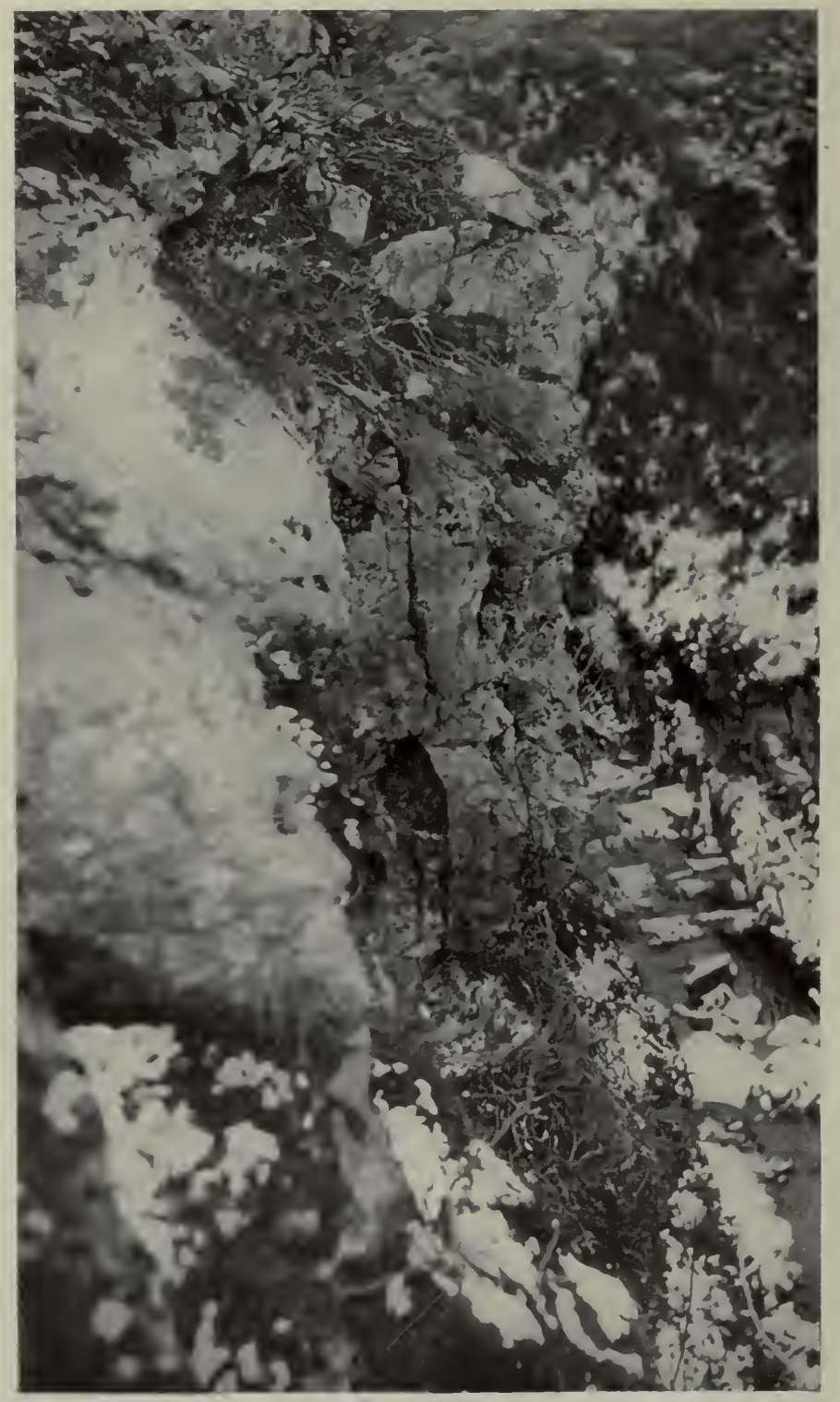

A RAVEN'S NEST AND EGGS IN A SNOW-CLAD GULLY. 


\section{A Hebridean Island and its Birds}

out and often dying, are found in the most unlikely places many miles from the coast.

I know the island at every season of the year-in winter when the spray from the great Atlantic waves drifts on the wings of the storm over the topmost point of the grassy hill, and in spring when all the mountain ranges of the mainland and of the Isle of Skye stand out in the clear sunshine with the smoke of many heather fires rising, blue and ethereal, into the quiet air. But of all the seasons it is during the months of June and July, in fine steady weather, as the fishermen say, that the charm of this island is at its height.

At this season, accompanied by a kindred lover of the island and its birds, I have pitched my tent on the green, grassy slopes, and day by day busied myself with the study and photography of the island birds. During such days of summer it is good to have one's home on this outpost. By reason of its configuration there is always shelter from the wind on some part of the island, and the sun shines on the sheltered slopes with great power and warmth. And what can be finer than from one's tent to see the first of the sunrise on the north-eastern horizon where, from behind a range of conical and far-distant hills the sun, a red glowing ball, first appears? And then when full daylight comes, what a marvellous view of hill, sea and glen can be spied from the summit of the little hill.

Eastward lie the great hills of the Scottish mainland, and when on the island the sun shines bright and warm, dark thunder-clouds often shroud these hills-one can, perhaps, see the rain descending in torrents from the clouds until all view in that direction is blotted out. One hill there is rising straight from the deep waters of the Atlantic that attracts to itself many clouds, so that even in the finest weather the mountain-top is often shrouded in mist. And of a summer's night what can be finer than to sit near the summit of the island and watch the sun slowly setting far out into the Atlantic, and afterwards, in the gathering dusk, to see, one 


\section{Wanderings of a Naturalist}

by one, tiny lamps appear from the misty spaces of the sea as the various lighthouses send forth their lights to guide the big ships or the sturdy drifters and trawlers at their fishing?

And then with the twilight there emerge at such times from the crevices where they had passed the long hours of daylight many of the tribe of the storm petrel. To and fro these small birds flit with swallow-like flight, and from the crannies between the boulders their brooding mates utter curious purring notes, pleasant to the ear and quite unlike those of any other bird.

Throughout the few hours of night they and the Manx shearwaters have the island to themselves and are the only birds stirring, but by sunrise many puffins and guillemots are arriving at the island with their night's catch of silvery herring fry or sand eels for their hungry youngsters, and all is bustle and activity once more, and the air resounds with many cries.

With the coming of autumn the summer bird visitors to the island take their departure for the open sea, and except for the storm petrels, which linger on till October and November, the island is left to the buzzard and raven and the lordly peregrine and the wicked greater black back.

But with the approach of winter a new bird people arrive at the island. Many swift-flying barnacle geese, coming on the north wind from the frozen regions that approach the Pole, and seeing it from afar recognize the island as their winter home. And so with much calling among themselves they glide downwards and together alight on the grassy slopes. They remain throughout the winter on the island, feeding on the pasture that, warmed by the soft Atlantic wind, remains green even when on the mainland the grass is browned and withered by the frosts. Here, then, the wild geese live until April; until, perhaps, the first days of May, and they may even see the coming of the summer hosts of birds to the 


\section{A Hebridean Island and its Birds}

island before rising in a body and setting their course for Spitzbergen. There, or in kindred lands set far beyond the Arctic Circle, they remain during the short northern summer, making their nests about the precipices that approach the Eternal Snows-nor do they think further of the island which gave them food and shelter when all the Arctic lands were fast in the grip of the ice and snow. 


\section{CHAPTER XXV}

\section{SALMON OF THE LINN OF DEE}

$\mathbf{I}^{\mathrm{T}}$

$T$ is at a point some seventy miles-by water-west of the North Sea that the Dee flows through a narrow rocky gorge, so narrow that in places it is possible to leap from bank to bank. For two hundred yards or so a succession of rapids alternate with small deep hollows, and at the foot of the linn is a pool of such depth that even when the water runs low and clear the bottom is scarcely visible. Year after year the river is imperceptibly, though surely, eating into its granite channel, and one can see deep hollows formed in the solid rock by the continual grinding motion of stones which the water swirled round in its vortex. Some of these hollows are at such a height above the present level of the river that this scouring action of the stones now takes place only when the water is in spate. One small and deep hole is particularly noticeable, for at the bottom it still contains the two rounded stones which formed it in earlier times.

Conditions at the linn are all against the successful passage of the salmon, and there is a certain irony in the fact that the last fall is the one which is the most formidable, and which indeed proves insurmountable to a considerable proportion of the fish. I have watched, day after day, the attempts of the salmon to conquer this last obstacle, and I must confess that not a single fish during that time succeeded in forcing a passage to the comparatively calm waters above. That many do succeed is an undisputed fact, for the river above the linn holds salmon in plenty, but they probably pass the 


\section{Salmon of the Linn of Dee}

falls at a certain state of the water when their progress is not so easily observed.

Everything is against these ascending fish. To begin with, they must first force their way through a stretch of swirling foam, and, having arrived at the foot of the last barrier which stands between them and their spawning beds, they have no pool in which to lie and regain breath for the all-decisive leap. A pool-of a sort-there was in olden days, but it is now filled with rocks, so that it is from a cauldron of foam that, dazed and half senseless from a too plentiful supply of air, the unfortunate fish must make their last rush. One's sympathies go out to them, especially when a gallant effort fails to clear the top of the fall by inches only. On either side of the linn, at the immediate foot of the uppermost fall, are two narrow strips of comparatively quiet water. The larger of the two is not more than a foot in width, but as many as half a dozen salmon may occupy it at a time, while in the other strip, on the south bank of the river, only a single fish, or two at the outside, can be accommodated. The water is so shallow here that the salmon are often half out of the stream, and lie there in the last stages of exhaustion until, in a second and more feeble attempt to negotiate the fall, they are caught in the quick current, and swept down to the big pool below the last of the rapids.

Twice a year is the linn busy with the passage of the salmon. The first migration is in early summer, and consists chiefly of those fish which have entered the river in midwinter. Fine, strong fellows they are, with their silvery sheen still on them. They, at all events, have little difficulty in passing the linn, and penetrate to the very highest reaches of the river, where, under the shelter of Beinn Bhrotain and Carn a' Mhaim-in the heart of the Cairngorm Hills-they carry out the perpetuation of the species. The second migration of the salmon, and that to which I have more particularly referred, commences in late September, 


\section{Wanderings of a Naturalist}

continuing for a month or six weeks. It can, I think, be put down as certain that a considerable proportion of the later run do not succeed in passing the linn, but have perforce to descend the river and seek fresh spawning beds below. They are not in the same fullness of strength as their fellows of the spring run. Some of them have been six months-and more-in the fresh water, others have come in from the sea in midsummer, but of true autumn fish I think I am right in saying there is an entire absence, though local authorities assert that certain quick-running salmon make the journey of seventy miles in forty-eight hours, and in autumn too. If the generally accepted theory that salmon do not feed in fresh water be correct, many of the fish visible at the linn in October have undergone a fast the like of which must put completely in the shade the most famous human feats in this respect.

It is a remarkable instinct that prompts these fish to press forward to the very highest reaches of the river. With true autumn-run salmon it is different: they are content to spawn in the lower reaches, only a few miles from the sea in some instances, and even a large number of spring-run fish regularly conduct their spawning operations many miles below the linn. It is almost certainly the case that the salmon of the linn had their origin in the waters beyond, and that it is this instinct to return to the place of their birth which urges them through the falls. One has only to inspect the pool below the linn to realize at what cost many of the fish attempt the passage. On a certain day I counted between forty and fifty salmon lying only a few feet from the surface, though the water was of great depth at this particular point. The fish showed a striking absence of fear; they allowed themselves to be inspected without suspicion, and even a succession of stones thrown in among them only caused them to sheer off slightly. Nearly every one of them bore a white Inark on the nose where it had thrown itself against the wall of rock in the last leap, and on one or two of their number 


\section{Salmon of the Limn of Dee}

were what appeared to be fungoid growths, but which were probably marks of their struggle with the falls. That fish do severely injure themselves is certain, and the thud of a salmon as it strikes the rock is clearly audible above the rush of the water. Often fish, having seemingly lost their sense of direction, take the leap at right angles to the course of the river, with the result that they fall heavily against the rock, and the wonder is that such leaps are not attended with more fatal results than is actually the case.

It is of interest to note the various types of fish which ascend the lower part of the linn-for all healthy salmon can surmount the earlier rapids with comparative ease. Many of the salmon are extremely red-some even have reached the stage when they rival in their blackness the peaty water which surrounds them-while others, cock fish, have assumed all the colours of the rainbow, appearing, it might be said, in the tartan of the hill country in which they find themselves. Now and again, however, a salmon is seen moving up the linn which is still thick-set and firm, one, in fact, that even now would be fit for the table; but such fish are the exception, especially towards the end of the autumn run. The weight of the salmon is small; from five to seven pounds may be said to be an average size, though fish of twelve and even fifteen pounds are occasionally noted.

It is of interest to observe the various methods employed by the salmon in negotiating the rapids of the linn, and I have noticed that the most successful are those fish which do not leap clear of the water, but which bore through the rush with such quick movements that they have reached the pool above almost before one realizes the fact. In the small "pots" between the rushes many salmon lie, recuperating their energies for a further attempt at forcing a passage. Some of these holes are almost circular in shape, and the salmon, sometimes so numerous as to appear in tiers, and all facing the current, present a memorable sight. The passage of the linn is occasionally attempted by brown 


\section{Wanderings of a Naturalist}

trout, but of sea trout there would seem to be a complete absence.

As winter approaches, and the temperature of the water decreases, so does the number of running fish diminish, until during the short December days one may watch the linn for weeks on end and yet see nothing but the peat-covered waters hastening to the far distant sea. 


\section{CHAPTER XXVI}

BIRD FISHERS OF THE SEA

LMOST all sea birds are fishermen. There are, it is true, exceptions, such as the small and delicate storm petrel which feeds on the minute animalculæ of the Atlantic and kindred oceans, and other members of the petrel family, including the shearwaters, but these exceptions are few and far between. On a fine summer's day-in the Minch, perhaps, or in the Passage of Tiree-I have often watched razorbills and guillemots moving singly or in strings just above the water's surface, making for their distant fishing grounds. The puffins I did not see so often-I think they do not range so far in their feeding as do either of the birds first mentioned-yet on the Hebridean Islands they nest in enormous numbers.

In their feeding the puffins seem to prefer sand eels. At all events these form the staple food which they provide for their young. At times Arctic skuas which nest on neighbouring islands await the returning puffin a few hundred yards out to sea. The skua is the arch-robber of the sea birds' world, for he lives entirely on the fish that he forces gulls, terns, and the like to disgorge as the result of his fierce onslaughts. A puffin attacked in this way realizes that escape through the air is impossible, for on the wing the skua is by far the swifter of the two, and so without hesitation plunges into the sea, diving, or rather hurling itself, beneath the water with its catch of sand eels still grasped firmly in its powerful parrot-like bill.

Most comical of birds is the puffin-it always seems so full 


\section{Wanderings of a Naturalist}

of its own importance, though with little brains to justify its conceit.

A true deep-sea fisherman is the razorbill; an intelligent bird, well before either the puffin or the guillemot as regards brains. Razorbills arrange their catch of herring fry with perfect symmetry across the bill, head and tail showing alternately. It would be interesting to know if the puffins and razorbills when fishing drop the fry they are already carrying before attempting to catch another, or whether they are able to capture a new victim with their bills all the while packed with its unfortunate companions. Both puffins and razorbills capture a number of small fry or sand eels which they hold across their bills, but the guillemot is content with catching one larger fish-I have never seen it with more than one-which it carries with the head well down its throat and the tail just projecting beyond the captor's bill.

On one occasion, on a Hebridean isle, I saw a guillemot feed her young. After standing for some time beside the chick, which was begging eagerly to be fed, the mother held down the large fry she was carrying, and the youngster, taking hold of it, swallowed it at a gulp, although the fish was nearly as long as itself. Another guillemot, probably excited by my presence, was unwilling to feed her young one, and ultimately swallowed the fish herself. The feelings of the chick at this point can be imagined!

Adjoining this island is a small, rocky islet to which, at dead low water, one can wade with the sea not above one's waist. One day of early July, on a beautiful sunny afternoon, I waded across in the icy cold water, slipping frequently on the seaweed. However, I got over with the camera dry, and found, on a wide, rocky shelf, comparatively easy of access, a large colony of nesting guillemots. About forty eggs lay on the ledge, most of them very dirty and discoloured, and obviously near hatching. In one case the chick was a quarter out of the shell, while in another the youngster had just emerged and was squeaking loudly. A 


\section{Bird Fishers of the Sea}

few chicks of a tender age were crouching about the ledge or shrieking shrilly for their parents. My appearance, clad in scanty garb, caused a commotion amongst the colony, and the startled birds grunted and groaned horribly, ultimately taking wing, with the exception of a few brave individuals who remained on till I was only a few feet from them, lunging towards me with their bills and saying extremely rude and forcible things in guillemot language.

On a larger and adjoining island there was only one small ledge on which guillemots nested that was easily accessible for photography. On this ledge a shag also had made her nest, apparently before the arrival of the smaller birds, and the almost full-grown young shags were a source of great annoyance to the brooding guillemots. Three of the latter birds tenanted this ledge, and one of them-a ringed guillemot-was the most fearless of the lot. Two small chicks were on the ledge, and when the other parent had been scared away the brave ringed guillemot used to "mother" both the chicks. On such occasions her life was rendered miserable to her by the two young shags which constantly got in her way. She pecked them so hard that they used to shriek with pain, and her bill was covered with their down. What increased her annoyance was the fact that one of the guillemot chicks seemed actually to prefer being brooded by the young shags, and was in the habit of leaving her and, unmindful of her entreaties to return, keeping warm beside one of these very unwelcome intruders.

A comparison in the method of walking of the puffin, guillemot, and razorbill is interesting. The guillemot occasionally walks balanced on its feet, but normally on the whole length of the leg up to the feathered thigh. As far as I have been able to see, the latter is the sole method used by the razorbill, but the puffin invariably walks in the usual upright manner.

Razorbills are usually a day or two earlier than the guillemots in hatching off their young. One July 5 I remained for 


\section{Wanderings of a Naturalist}

some hours near to a small colony of nesting razorbills. Under a large boulder, in semi-twilight, there crouched a young razorbill several days old, with the two halves of the egg from which it had emerged lying beside it. The parent razorbill was in the habit of alighting on the top of the boulder with supplies for the youngster, and by very careful stalking I was able to approach to within five feet on several occasions and secure a number of photographs. On arrival the bird usually carried four or five herring fry in her bill, and on one occasion she alighted with no fewer than seven.

On this flat-topped rock there were wont to congregate half a dozen razorbills, though I do not think that they all had young near; at all events, I was unable to locate them. As they stood together in the warm, still air they used, periodically, to raise their wings, and after holding them for a second or two outspread, flap them vigorously. They scarcely ever uttered any sound, but when I approached too near for their peace of mind, they used to open their bills in a harassed fashion. One could not help noticing, when at such close quarters, their extremely interesting and intelligent expressions, in marked contrast to the somewhat senseless appearance of the guillemots. The latter, as they brooded their eggs, gave the impression of being "perfect ladies," though possessed of little sagacity. Their eggs they quite frequently knocked into the sea on being startled, and then shrieked in dismay.

The study of the puffins which frequented this island, literally in their thousands, was interesting. The birds had certain rocks where they used to go and sit and apparently hold consultations and conversations, and while thus engaged showed a complete lack of fear. Indeed, one individual actually fell fast asleep with head tucked away among its feathers while I was kneeling with camera in position not more than four feet away.

The puffin is quite a fast flier, though its wings are very small for the size of its body. During days of strong wind 


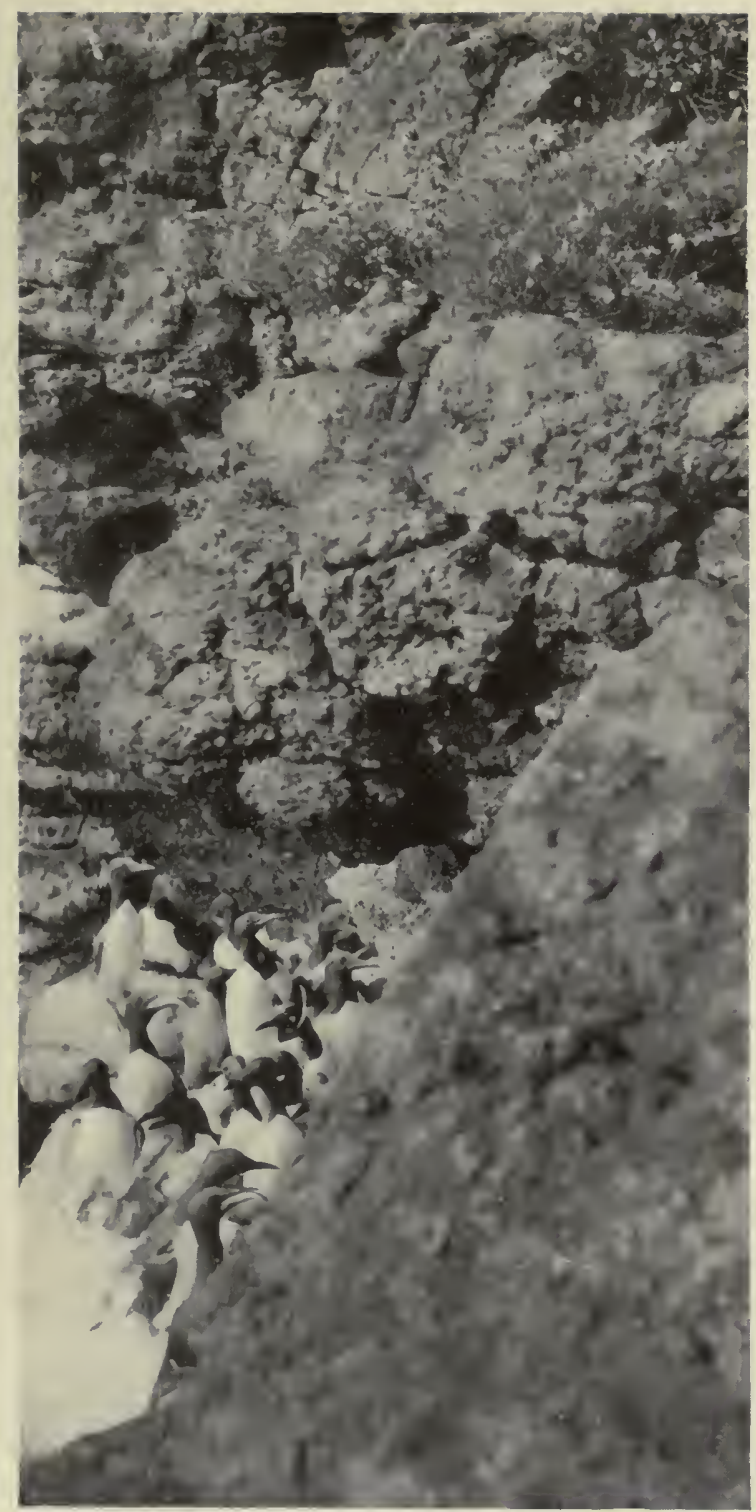

GUILLEMOTS WITH THEIR CATCH.

Only one Fish is carried-Head Down the Bird's Throat. 


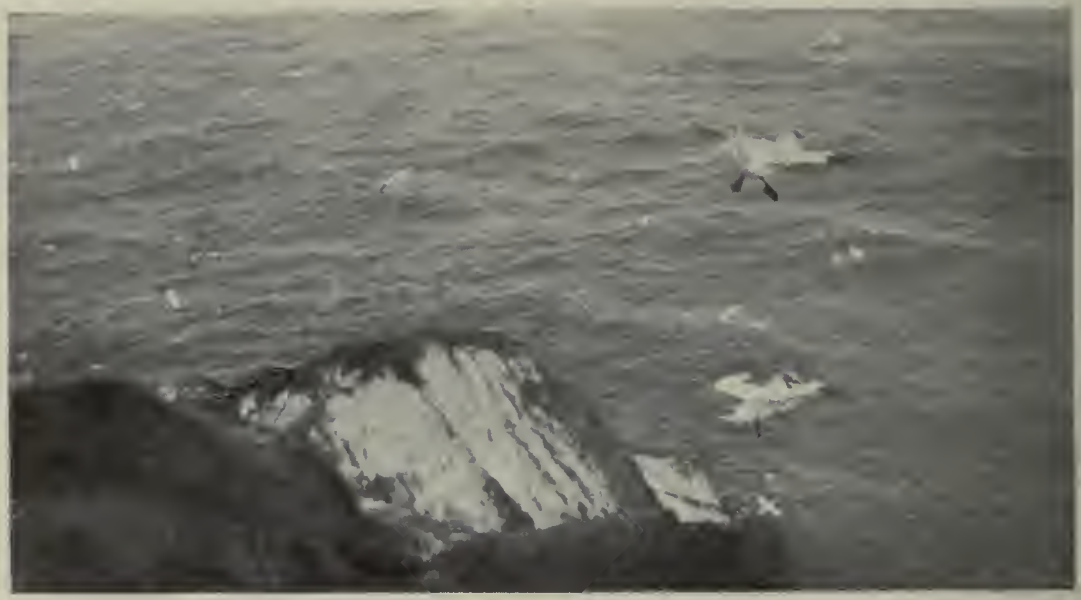

Hovering on the Upward Current.

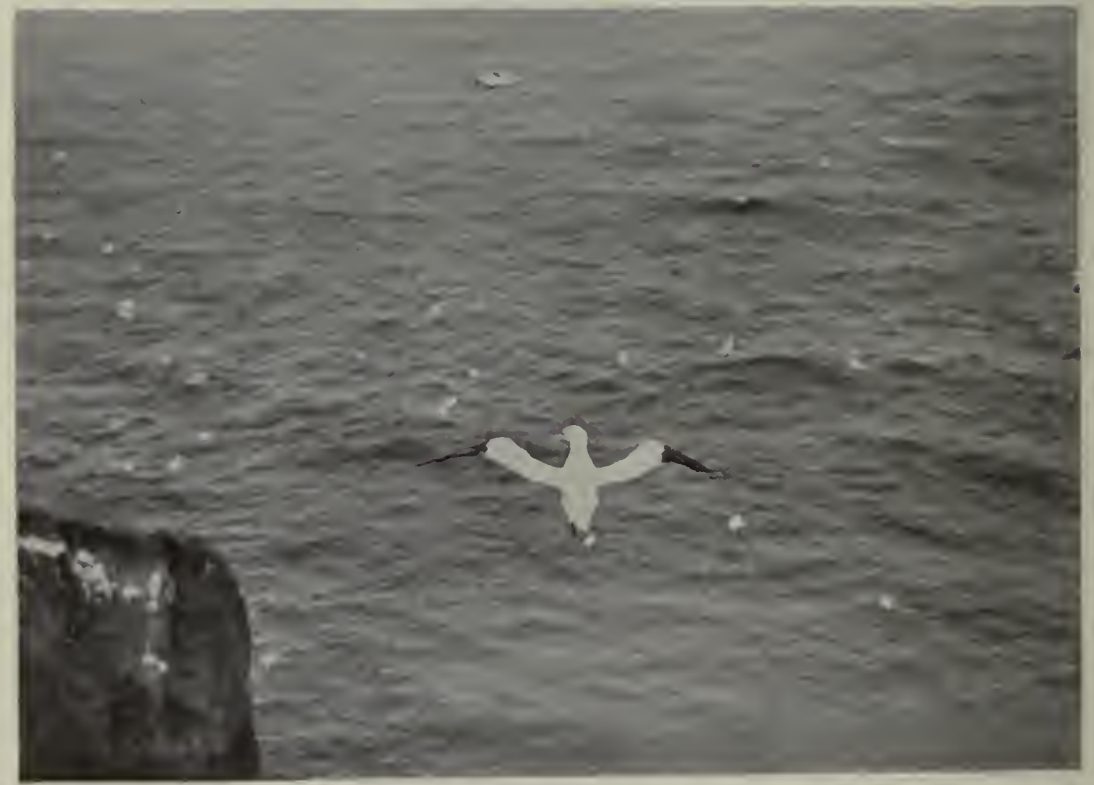

Making for the Open Sea.

GANNETS AT THE BASS ROCK. 


\section{Bird Fishers of the Sea}

it was ludicrous to watch the puffins soaring round the rocks, or rather endeavouring to soar, their small stunted wings giving them a most comical appearance, for the puffin is the very last bird that one might expect to see sailing on motionless wings in the teeth of a strong breeze.

On revisiting this island in the last week of August, out of the countless thousands of puffins, razorbills, and guillemots which had nested here, I could see only two puffins still catering for their young, while not a single razorbill or guillemot remained, so that the island, which six weeks earlier had pulsated with life, was now strangely quiet and deserted. 


\section{CHAPTER XXVII}

\section{SEPTEMB̈ER ON THE BASS ROCK}

TANDING prominently in the North Sea, near the eastern entrance to the Firth of Forth, the Bass Rock rises precipitously from the water to a height of some 400 feet and is a conspicuous object for many miles around. In early days the Bass was strongly fortified, and later was used as a military prison. To the ornithologist, its chief interest lies in the fact that it is the only nesting-place of the gannet, or solan goose, along the whole eastern seaboard of these islands. For centuries the solans have reared their young on the Rock; in 1447 one finds first mention of them, and one reads that in 1764 over 1,200 birds were taken and sold for is. 8d. each. At that time there were restrictions as to the killing of the solans, so the thousand and more victims must have been obtained by the owner of the Rock himself.

The first Act for the protection of the gannets was passed in 1583 , two years after James VI. paid a visit to the Bass. By this Act the taking of the solan was forbidden "in the pane of twentie pundis," or, should the fine be beyond the means of the culprit, he was to be "wardit within the place of the Bass during the space of ane yeir thairafter." The owner of the Bass was exempt from this Act, and even at the present day the lessee of the Rock is allowed to remove an unlimited number of eggs and young birds. The parish minister of North Berwick may, if he chooses, take a dozen solans yearly, but the taking of the eggs or young and the shooting of the adult birds by the general public is strictly forbidden.

The solan goose is, with the exception of the tribe of the I30 


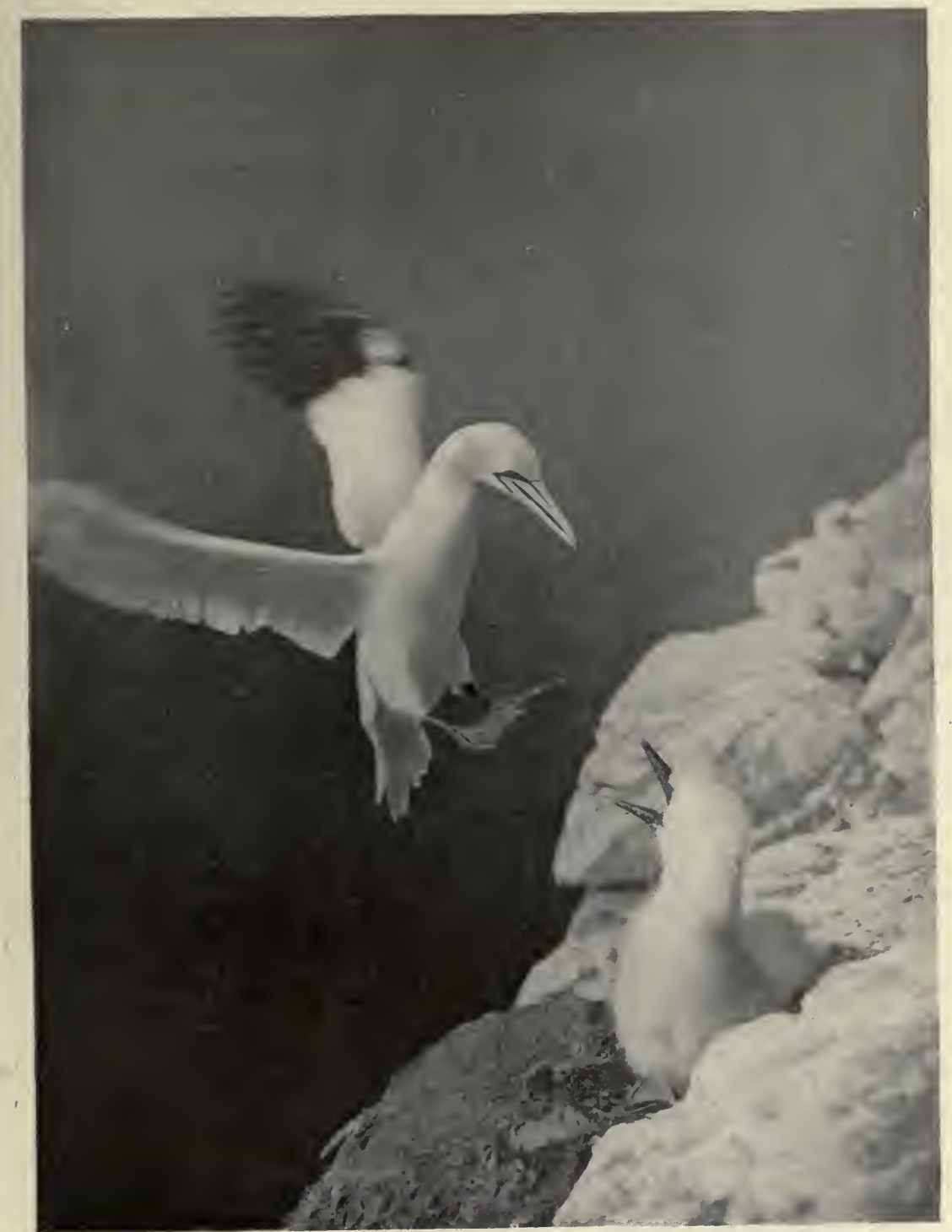

GANNET: POISED. 


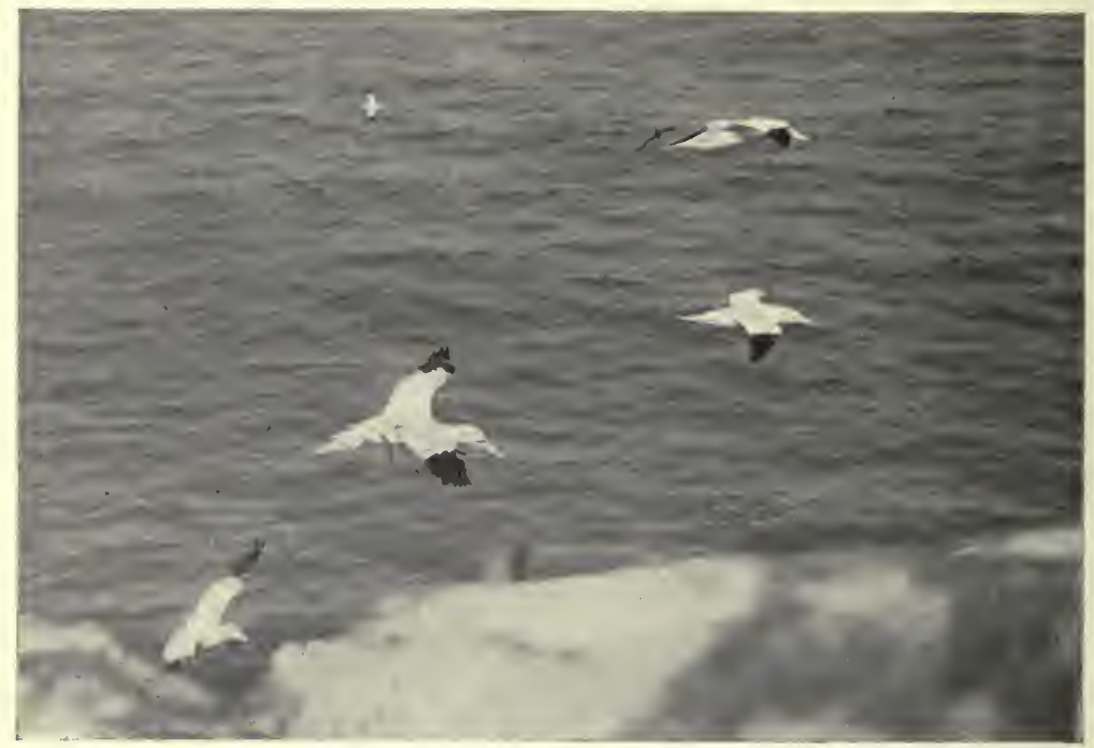

Gannets at the Bass Rock : "Full steam ahead."

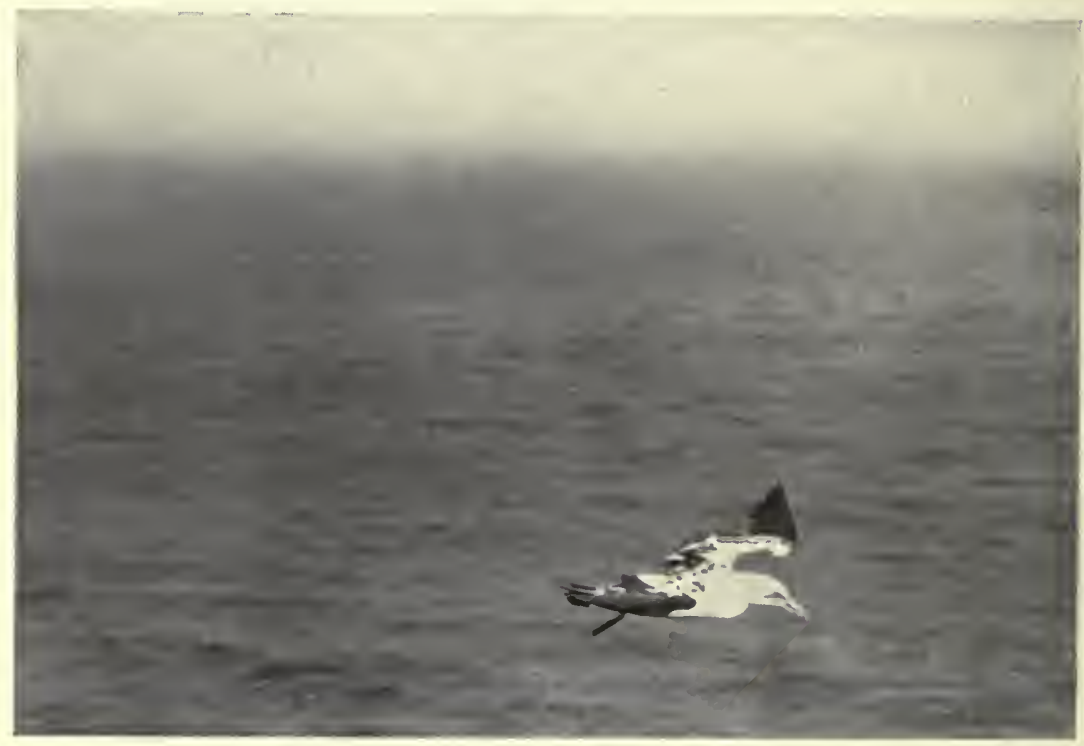

An Immature Two-year-old Gannet. 


\section{September on the Bass Rock}

petrels, unique amongst our British birds in still tending its young in September. The period of incubation is six weeks, and the young birds are not able to leave the Rock until they have been tended by their parents for nearly three months. Towards the end of the second week of September, during a recent season, I spent some days on the Bass Rock studying the bird population of the small island, and although at times the weather was exceedingly stormy, I succeeded in gathering a certain amount of information concerning the nesting habits of the gannet in early autumn.

On September 15, I should say that sixty per cent. of the young gannets had made their first flight from the Rock, while of the remaining forty per cent. many were in the downy stage and would not leave the nest for another month. One particular nest I had under observation contained a downy youngster with his flight feathers just commencing to sprout.

After a storm of wind from the north-east, much seaweed was floating on the surface of the water, and gannets were everywhere busily engaged in repairing their nests. In one particular instance, what I took to be the hen bird remained at the nest guarding the young, while the cock made frequent excursions to the water, returning with his bill full of seaweed. But on one occasion he appeared, carrying, not seaweed, but a billful of straw, which he deposited on the back of the youngster. Instead of utilizing this straw for the nestbuilding purposes, the mother bird left it severely alone, and on the return of the husband a minute or two later with his bill again full of straw, mixed with some seaweed, he found his previous offering of straw quite untouched. And now a quite noteworthy incident happened. Instead of depositing both straw and seaweed in the nest, the male bird, apparently taking in the state of affairs, solemnly dropped the seaweed in front of his wife and then sailed off, still carrying in his bill the unwelcome straw.

The whole incident seemed to me to be a clear case of I 3 I 


\section{Wanderings of a Naturalist}

reasoning, though in many ways the intelligence of the solan is very low in the scale. It is, for instance, almost incredible that, after tending her young assiduously for ten to twelve weeks, the mother solan should take not the faintest interest in its initial flight from the Rock. Even if, during this first flight, the young bird should lose its nerve and be dashed to death on a projecting ledge, the parent still betrays not the slightest anxiety as to its fate.

On the morning of September 14 I had a young bird under observation. It was well grown and was periodically fluttering its wings as though anxious to be off. Occasionally it would make pretence at nest-building, picking up straws in its bill and strewing them about aimlessly. A little later on in the day, when the parent bird was beside it on the nesting ledge, it set out on its first flight. For a young bird leaving the Rock for the first time its flight was exceptionally strong, and it progressed a distance of quite half a mile from the Rock before alighting on the sea. I immediately turned my glasses on the old bird to see whether she had taken any interest in the departure of her offspring. Unbelievable though it may seem, she was sitting contentedly on the remains of the nest and was busying herself in replacing odd pieces of straw and grass, while the very existence of her youngster had apparently faded entirely from her mind!

Nest-building is a habit firmly implanted in all gannets young and old. I noted that the youngster for whom-as I mentioned before-seaweed and straw were brought, worked as assiduously as its parents in welding the newly-deposited material into the hardened foundations of the nest. In the bottom of this nest the half-digested remains of a fish were lying-disgorged, probably, by the young bird-and once, on the latter moving to the side of the nest, the parent caught sight of the remains. She evidently came to the conclusion that the object must be removed and that the most obvious thing to do was to eat it herself. Doubtless the fish had long passed the stage when it could be termed fresh, and the 


\section{September on the Bass Rock}

gannet settled to her work with a certain amount of reluctance, shaking her head from time to time and scattering small pieces of the fish about as though in disgust.

One day a considerable amount of debris floated near the base of the Rock, and amongst it were what appeared to be a number of cabbage stalks. Naturally these objects were eagerly tested by the gannet population with a view to discovering whether they were suitable for nest-building, but the general decision arrived at was that they were too heavy and clumsy for this purpose. A case of extreme selfishness-or was it bad feeling? - was noted in connexion with this. A gannet swimming on the water was testing one of these cabbage stems, and although there were many others floating around, a second gannet determined not to allow the first comer to remain in undisputed possession of the field. Flying down, therefore, to the water's edge he angrily drove off the bird in possession, but then made no attempt to utilize the stem he had captured.

Gannets are remarkably powerful in their flight, and I saw them to full advantage during the succession of strong winds which swept the Rock. At times such as these an endless procession of solan geese would soar steadily in the teeth of the wind, almost touching the Rock, and passing within a few feet of where I watched. It was where the wind, blowing straight in from the open sea, shot up over the precipices that the prettiest flying was witnessed. In the swiftly uprushing current the birds had considerable difficulty in alighting on their various ledges. Their method of procedure was to swoop down from a height, and as they approached their particular ledge to halt in their flight, rocking from side to side, with tail bent upwards so as to preserve their equilibrium, and feet pointing downwards and far apart. Sometimes, when the wind was violent, they hovered in the air with rapidly vibrating wings, appearing for all the world on such occasions like gigantic kestrels. While on the wing together the birds were decidedly nervous, 


\section{Wanderings of a Naturalist}

and often an individual would swerve off with an alarmed cry, imagining, and often groundlessly, that a bird soaring near and slightly above it was about to attack.

There was one gannet still brooding closely on a very diminutive youngster on which the down had just commenced to grow, and putting the age of the young bird at a fortnight, the egg cannot have been deposited much before July I 7 . Even at its early age the young bird, when it was partially uncovered by its parent, endeavoured with its small beak to do what repairs were, in its opinion, needed for the improvement of the nest, presenting in its task an extremely quaint and delightful spectacle.

On September 13 the wind blew very strongly throughout the day from a north-easterly quarter, with heavy rain. Next day a number of small migrants were seen on the Rock, and some were still remaining on the 16 th. I noted several redstarts, at least one snow bunting, and quite a number of wheatears. A willow warbler paid a short visit, and hedge accentors were numerous.

On two occasions on the I6th I noted a-peregrine falcon, once flying and later resting near the summit cairn. In former years the falcon nested on the Bass, but latterly has made its nesting site the island of Craig Leith, a few miles westward up the firth. In its choice of a nesting site it has been singularly unfortunate, for I hear that every spring the eggs are removed from the eyrie by collectors.

When I left the Rock just after mid-September, young gannets were leaving their nests daily, but it was not until late October that the more backward took their departure, and in the case of the small youngster just mentioned, November must have been drawing to a close before he was ready to take the momentous first flight into the wide world. 


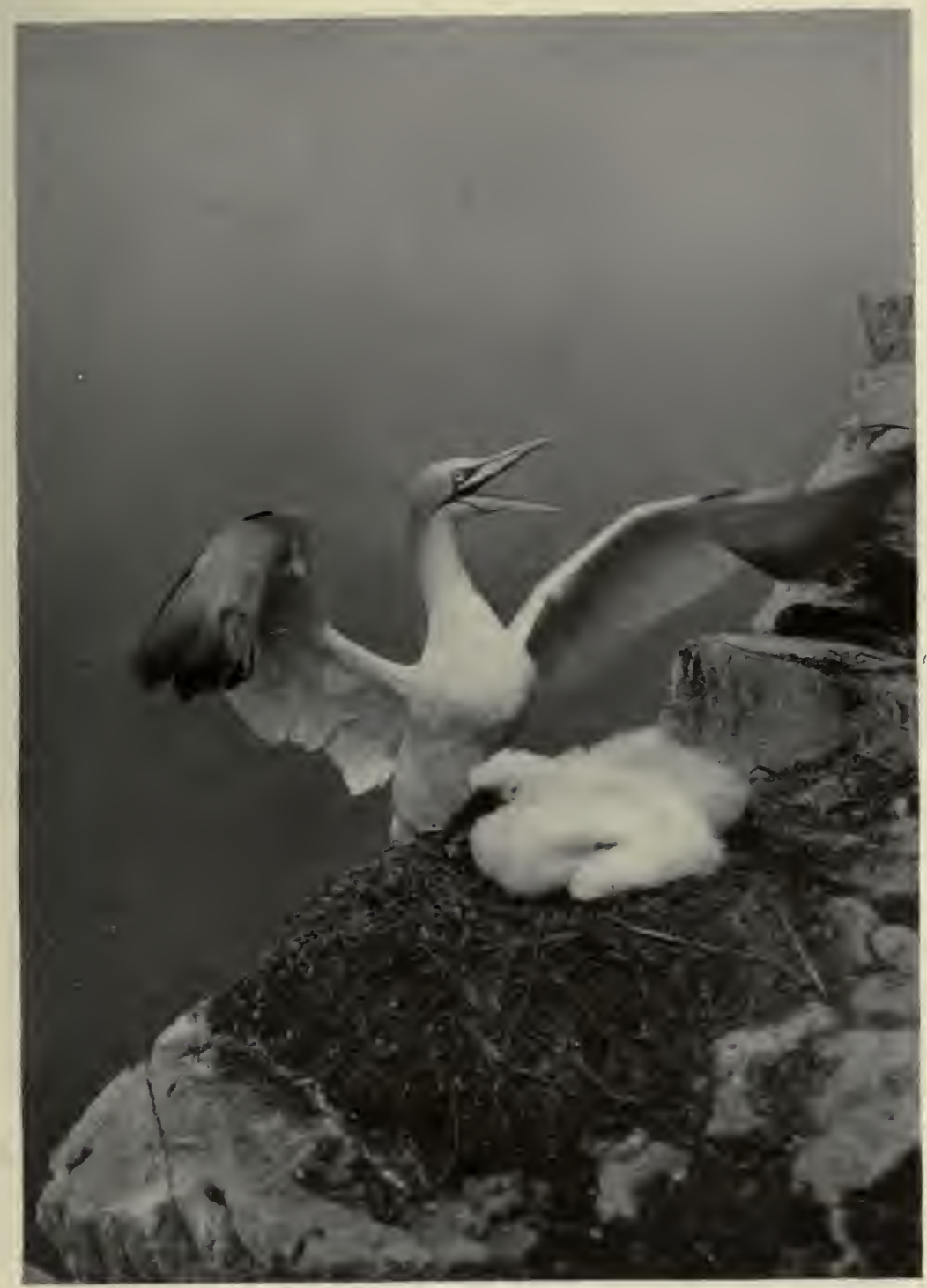

"GOOD HUNTING, MY CHILD."

(Gannet and Young.) 


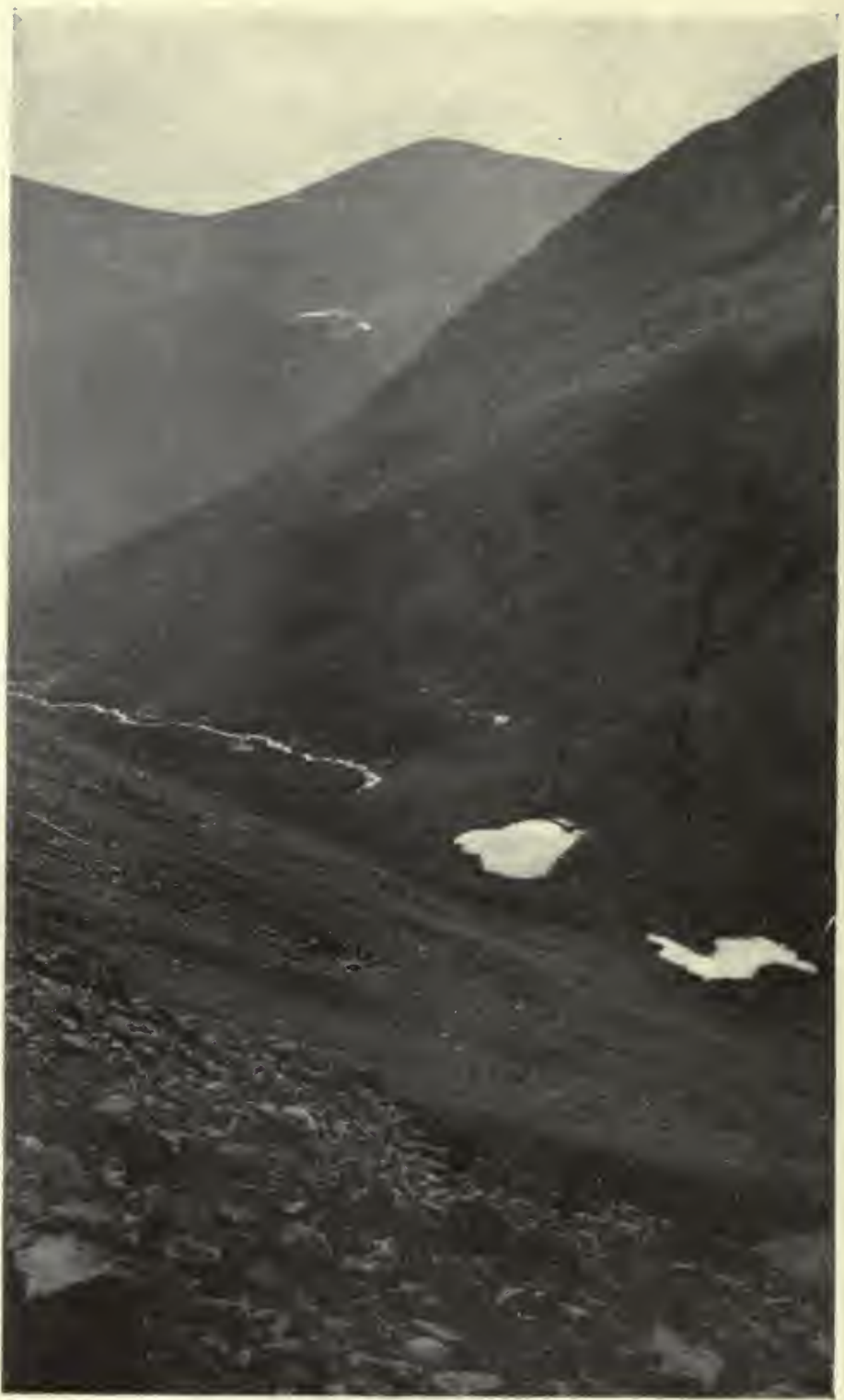

THE POOLS OF DEE, WITH LOCHAN UAINE IN THE DISTANCE. 


\section{CHAPTER XXVIII}

\section{OCTOBER IN LAIRIG GHRU}

$\mathrm{O}$ $\mathrm{N}$ an early October morning, after a spell of exceptionally severe weather, the wind, blowing fresh from the south, brought drizzling rain and a mist which covered the hills to their lowest slopes. Towards noon the wind shifted west-always a good weather sign-the clouds lifted, and I set out from Glen Derry in Mar on my journey through the wild Lairig to Rothiemurchus on Speyside. The wind was soft and mild, and as I struck west, Beinn Bhrotain and Monadh Mor-the two big hills that guard the Lairig near its southern end-showed darkly through the mist, their corries heavily splashed with fresh autumn snow. The Luibeag burn was in spate, its waters having that characteristic appearance of "snaa bree." From where the track crosses the burn near the foot of Carn a' Mhaim the south-facing corries of Ben MacDhui and the conical summit of the Derry Cairngorm presented an almost unbroken surface of snow. Even on Carn a' Mhaim the drifts lay deep.

But amongst the storm-scarred pines in the glen winter had not yet obtained the mastery. Cranberries, fully ripe, still showed in sheltering places, and trout splashed in the shallows of a small burn.

As I rounded the shoulder of Carn a' Mhaim, where the path just touches the 2,000-foot level, a heavy rain squall from Glen Geusachan swept across, blotting out hill and glen, but soon passed by, and now that steep and rocky spur, the Devil's Point, stood out corniced with snow and, lying snugly at its base, the lonely and small Corrour Bothy. I do not remember having seen the Dee here running in bigger 


\section{Wanderings of a Naturalist}

spate-for the sudden thaw on the high hills had brought much snow water from the corries-and the rushing of the river carried far in the stillness of the glen. Cairn Toul itself was hidden in mist, but Ben MacDhui was clear, with glimpses of sunlight showing up the great snow wreath lying at the head of Coire nan Taillear-or the Tailors' Corrieand the burn, running fast and strong, suddenly emerging half-way down the hillside from beneath the snow.

The boulder-strewn Garbh Choire, stretching away westward into the mists, carried much snow in its gloomy recesses, and the field of the previous winter's snow-which has never been known to disappear even during the hottest of summers -was hidden from view by fresh and deep drifts. In one place an avalanche of snow had been loosened by the thaw, and its snowball-like accumulation lay strewn on the hillside. Poised just above the ridge of Ben MacDhui was a small, dark object which, through the glass, was revealed as a peregrine falcon. Motionless he hung in the teeth of a strong breeze, hovering like a giant kestrel as he scanned the ground beneath him. After a time, swinging round in a circle, he searched another part of the hillside and here seemed to spy something, for he dropped again and again, hovering motionless between whiles until he had reached a point only a few yards above the ground. I do not know whether he secured his quarry, for watching him was difficult in the uncertain light.

I have rarely, if ever, seen finer colours of light and shade on the Cairngorm Hills. Between the showers the air was exceptionally clear, and the snow-freed corries and slopes were of an extraordinarily deep blue and appeared wonderfully near. Even the snow itself at times took on a pale blue tint. Inky black clouds spread across the hills from the west, and then almost instantly disappeared, to be replaced by a sky of turquoise blue. It was only very occasionally that the sun shone on Ben MacDhui, and never during this day on Braeriach or Cairn Toul. 


\section{October in Lang Ghru}

I passed the first snow near the Pools of Dee. Even at this height-and the path here approaches the 3,000-foot level-the air was mild, for the steep face of Sron na Lairige sheltered the pass from the strong breeze. Snow wreaths lay around the Pools of Dee, and in the pools themselves there floated remnants of snow and ice. Some of the hill fernsprotected from the frosts by their covering of snow-were still green, and the grasses here were indeed more green than in the glen below. The leaves of many blaeberry plants lay scattered on the surface of the snow-for, unlike the cranberry, the blaeberry is one of the most sensitive of hill plants to a sudden frost-and through the snow there led a wellmarked track, where stags had been crossing from Mar to Rothiemurchus in the quest for hinds.

I had reached the summit of the Lairig without encountering a single ptarmigan, but when just on the watershed a cock "tarmachan" rose from the hillside above me and flew at a considerable height and with zig-zagging flight, across the pass, alighting carefully on a snowfield. Through the glass I could make out his plumage to be in the transition stage, but with the white feathers of the winter dress predominating. I felt confident, by the flight of the bird, that I was not the cause of his alarm, and sure enough, on looking round, I spied the hereditary enemy of the ptarmigan-the golden eagle. Sailing leisurely through the Lairig the great bird passed right over the spot where the ptarmigan was crouching-seemingly without noticing him-before crossing the pass and making towards Cairngorm.

A few minutes later a covey of some six or seven ptarmigan came flying wildly from the direction in which the eagle had disappeared. A second time the eagle beat up the pass, and I thought I heard him call shrilly once before he sailed up into a mist-filled corrie and was lost to view in the mantle of cloud.

A last backward glance showed Cairn Toul and the Devil's Point very dark against the sun-flecked sky, and away to the 


\section{Wanderings of a Naturalist}

south'ard the big hill of Beinn a' Ghlo, mist-capped, but with large snowfields on its lower slopes. Northwards the valley of the Spey was bright in clear sunshine, while behind it stood out the broad outline of Ben Wyvis, and farther away the conical peak of, I think, Ben Mor Assynt. An eddy of wind from now onward rushed through the Lairig from the north, in gusts attaining the force of a gale, and at times catching up the waters of the March burn-where, indeed, it was not running beneath a covering of ice and snow-and lifting them up in spindrift.

In the calm intervals the roar of the wind in the rocks mingled with the rush of the burn, and in the dark, swirling mists and great snow-filled corries one felt that here indeed was the very heart of the hills.

A couple of miles below the summit of the pass I saw a covey of grouse flying in the same agitated manner as the ptarmigan, and in this case also an eagle-possibly the same bird-was the cause of alarm.

And now the woods of Rothiemurchus were showing. Big areas of Scots firs interspersed, here and there, with weeping birches with foliage of golden tint, or rowans with their leaves of sombre red. And what a wonderful crop of rowan berries covered the trees that autumn; indeed, so heavy were the clusters of fruit that the whole tree in some cases drooped.

Many stags were roaring in the early twilight of this October afternoon; one in particular, a fine heavy beast, with a good head, threw out his challenge persistently with a deep. and strong voice.

Looking backward now, the whole range of the Cairngorms stood out in the fading light. Apparently from the position of the wreaths there had been two distinct driftings of snow -one from the north-west and north, the other from a southerly direction. The deep corries of Cairngorm held a great snowfield with its cornice showing even at a distance of quite six miles. In depth it must have been at least from twenty to thirty feet, probably much more. The upper slopes 


\section{October in Laing Ghru}

of Braeriach were of an unbroken white, and for one minute the summit plateau, Arctic in appearance, stood out before being quickly shrouded in cloud once more. Sgoran Dubh, to the west, carried much snow, though not so great a depth as its higher neighbours.

Low in the western sky the new moon shone brightly. Darkness came quickly in the forest of pines, and with its coming the roaring of the stags increased. A woodcock rose at my feet, flitting off quietly in the twilight, and the murmur of the wind in the firs and the rushing of the hill burn were borne pleasantly to the ear at the close of the day. 


\section{CHAPTER XXIX}

\section{HEATHER}

D URING the months of late summer the plants of the heather tribe, with their countless blossoms, transform mile upon mile of lonely moorland from dark brown to pink and crimson-colours to delight the eye.

In the Scottish Highlands three species of heather are met with-namely, the common ling or the typical heather of the grouse moors, Calluna vulgaris, the bell heather, Erica cinerea, and the more pinkish-flowered Erica tetralix, or cat heather, as it is sometimes called.

Of the three, Erica cinerea is perhaps the first to blossom, and is often a full month ahead of the ling. It grows at its best in very dry situations, and sometimes I have seen it flowering with wonderfully vivid blooms of crimson in the dried-up course of some hill stream, where no soil was apparent. It frequently appears first after the burning of a moor, holds the field for a few years, and is then surely but gradually mastered by Calluna vulgaris.

The bell heather has by far the most powerful scent of all the heather plants; a July visit to a moor where this heather grows in profusion, when the air is still and when the sun shines strongly, will live long in the memory by reason of the wonderful colouring of its blossoms-visible, indeed, at a distance of many miles-and the fine scent which, from its freshness and purity, is a thing to delight the senses. An interesting point $I$ have noticed is that the bell heather is later in blossoming along the western seaboard than farther eastin Aberdeenshire, for instance-and is rarely in full bloom until August on the moors near the Atlantic. 


\section{Heather}

Erica tetralix may at once be recognized by the paler colour of its flowers. Unlike Erica cinerea, it is fond of boggy ground, being rarely found on the dry hillsides, and the plants do not grow in such close proximity nor so densely as those of the other two species. E. tetralix continues to send out flower shoots throughout the summer, whereas the bell heather and ling do so only exceptionally. This latter species, besides being the most common, is also found at the greatest elevations. On the Cairngorms the limit of the growth of ling is about 3,300 feet, but it is not often seen above the 3,000 line. During the last 500 feet of its vertical range, the plants show a creeping or prostrate habit, and rarely, if ever, produce any flowers. I have frequently come across clumps of white heather-easily recognizable by their lighter tinge of green-at very high levels.

The ling seems to be one of the slowest recoverers from the effects of winter snow amongst all high-growing plants. Snow drifted into a corrie by heavy winter gales may lie till late in the spring or well into summer, and the ling, when first exposed, is found to be pressed flat on the ground. If conditions are favourable, the plants gradually assume the upright position once more, but should the weight of snow have been unusually great, or the melting more protracted than usual, the heather plants remain prostrate, or partially so, throughout the season, though they endeavour to shoot in that position as far as the short period of warm weather remaining permits them. Heather is rarely killed by drought, being an essentially zerophytic plant. Its small leaves are tightly rolled back at all times, protecting the stomata or breathing pores from hot sunshine or strong drying winds, and thus preventing too rapid transpiration.

But the remarkable drought which characterized the summer of 1919 was sufficient to kill outright large stretches of both Calluna vulgaris and Erica cinerea, the plants turning a light grey colour and becoming absolutely dead. In other cases the flower buds failed to open and either remained 


\section{Wanderings of a Naturalist}

dormant, blossoming long after their time, or dropped to the ground. The contrast during the last days of August, 1919, between the heather in central Aberdeenshire and the Hebrides was a striking one, for in the latter district the summer had been uniformly wet and cold, whereas in Aberdeenshire the drought was the most severe for half a century.

White heather of the three species is not uncommonly met with. Calluna vulgaris gives the largest areas, but owing to the craze for "white heather," these areas are rapidly decreasing in all the more accessible districts. During a recent summer I came across a plant of Erica cinerea of a very unusual colour - a mauve tinge which this heather is normally wont to assume in the dried state. In this case, however, the plant was alive and vigorous. In the Hebrides and along the western coast all heather is far more sturdy and prostrate in habit than in inland districts. This is owing to the constant moisture-laden gales which sweep in from the Atlantic.

Along the western seaboard of Ireland, which in many places closely resembles the Western Highlands, a fine heather-Erica Mediterranea-is found. This heath grows usually on the hillsides facing away from the Atlantic storms, and is the largest of the ericas I have mentioned. Curiously enough, it blossoms in December, January, and February, and it is very pleasing to see areas of its handsome flowers at a time when all other wild plant life is dormant. It is not, I think, met with anywhere along the western seaboard of Scotland.

St. Dabeoc's heath-Dabeocia polifolia-is another heath, and an extremely beautiful one at that, which is found in Ireland and not in Scotland. It resembles somewhat a very large and handsome plant of Erica cinerea, with beautiful crimson flowers. I have seen it flowering along the seaboard of Connemara in mid-August. 


\section{CHAPTER XXX}

THE ROARING OF THE STAGS

T $\mathrm{N}$ a well-known forest is a wide and grassy glen where hinds are found throughout the year, and where, in early October, the big stags assemble to fight out their battles. The roaring of the stags on a fine mid-October night in this wild glen, as the moon rises slowly over the hill to the eastward, is a sound which, once heard, remains long in the memory.

On one such night I happened to traverse the glen. In the darkness the roaring of the stags sounded with peculiar charm. Two voices especially could be distinguished. One stag I knew from his hoarse cries; he was a fine beast, whom I had watched on previous occasions and who, when I last saw him, was master over forty hinds. Across the glen from him a second stag was roaring with fine musical voice, and as I moved forward, this stag, with his attendant hinds, stampeded across in the darkness right in front of me, making straight for that part of the hillside whence came the hoarse roarings of the big stag. From what I had seen of the size and prowess of the latter, I imagined he would drive off this trespasser on his ground with no difficulty. In the darkness nothing could be seen of the fight that followed, but I could hear clearly the striking of horn against horn-a sound extremely grand, and entirely in keeping with this lonely glen after nightfall. After a short time the fighting ceased; but the hoarse roaring of the big stag was silent, and the deep calls of his rival coming from the spot where he was formerly heard seemed to point 


\section{Wanderings of a Naturalist}

to the fact that the master of that side of the glen had more than met his match.

On another occasion - a little earlier in the year-the big stag had rounded up his large herd of hinds on a grassy hill face, while he himself was feeding quietly a considerable distance above them. As I watched, a smaller stag who had been loitering near, approached the hinds, but was immediately perceived by the lord of the herd. I do not think I have ever seen a stag cover the ground so rapidly as did this big beast as he charged down the hillside. The young stag cleared off immediately, but although he had a good start, the old warrior was not content until he had caught him up and prodded him vigorously in the rear with his antlers.

One day in this forest I was witness of an extremely interesting occurrence. Near each other were two stags, both heavy beasts with fine heads, but one animal slightly superior in weight to the other. The latter stag had the larger following of hinds, and it was evidently his intention to round the hinds of his rival into his own herd. Though he had a slight advantage in weight, he hesitated to force a fight, and so time and again the two stags paced slowly across the hillside, often only a few feet distant from each other. The heavier beast roared repeatedly in the endeavour to intimidate his rival, sometimes walking close behind him, as though debating the advantages of a bold charge, but on each occasion coming apparently to the conclusion that the results might be somewhat unpleasant for himself. By a certain amount of mancuvring, however, he succeeded in rounding in his rival's hinds, one by one, into his own herd, until at length only a single hind remained to the stag who had thus been morally defeated. For a time he succeeded in keeping his last remaining wife with him, but she too went in the end across to the others. When I last saw the unfortunate stag-now quite alone-he was moving slowly and thoughtfully out over the ridge to the hills beyond.

A really serious and protracted fight between two stags 


\section{The Roarng of the Stags}

is a comparatively rare event in the hill country-but two instances came to my knowledge.

In one, after a fierce struggle, the weaker of the two stags was forced to the ground, where he lay on his side, quite motionless, throughout the day. It was thought that he was dead, but a closer examination showed that he was still breathing, though incapable of movement, and during the following night he disappeared. In the second instance the defeated stag was found shortly after he had met his death. The body was quite warm, and in the side, just by the shoulder, were the wounds caused by the antlers of the opposing stag.

I was once watching some stags, with a few hinds among them, on a grassy hill face. Restless movements among the herd were frequent, and during one of these a small stag was pursued by a comparatively heavy beast. The youngster ran off without having seen his pursuer, and after trotting a few yards turned aggressively, thinking his opponent was another of his class. His start of surprise and change of tactics as he saw the form of the big stag making for him were laughable, and he disappeared over the ridge at his greatest speed.

All through October much restlessness prevails in the forest, but by mid-November the roaring of the stags is lessening and quiet is settling down once more on the hills and glens. Gradually the stags and hinds separate, each sex keeping to its own particular part of the forest until autumn again fills their minds with unrest and calls them to the big glen. 


\section{CHAPTER XXXI \\ THE SPAWNING OF THE SALMON}

$\mathrm{T}$

J HE scene is the uppermost reaches of the Dee, with great hills rising abruptly from the river, and farextending primitive forests of Scots fir, in which stags roar during the season of early winter. An intense frost holds hill and glen in its grip. Close on two feet of snow cover the ground, and the fall is extraordinarily even -no drifts even in the most exposed situations. Each fir tree is heavily weighted with snow, and where the sun has shone full on the forest the snow has been half melted and transformed into icicles, which hang from the dark branches. The sky is cloudless and of a deep clear blue. Eastwards, Lochnagar is an unbroken expanse of white, for even on the precipices that rise from the lonely and gloomy Dubh Loch the soft feathery snow has gained a lodgingplace. North of the river, Beinn Avon and Beinn a' Bhuird show scattered specks of black against their virgin expanses; in reality herds of deer searching for food along their lower slopes. Through the snowy valley the Dee runs as a dark broad line. Its waters, shrunk by the frost, bear seawards broken masses of ice. At one point the river divides into two, forming an island in mid-stream, and in the shallow water near the banks many salmon spawn. It is only the spring fish that have their spawning beds at the head waters of the Dee. The autumn run of salmon, heavier and more sluggish, do not penetrate nearly so far inland. There is nothing that hastens spawning so much as a spell of frost, and to-day the river seems alive with fish. During spawning, salmon lose much of their timidity, and one can approach near to the fish by careful stalking. 


\section{The Spawning of the Salmon}

At one point of the shallows two cock fish of about twelve pounds each are slowly swimming from side to side of the gravelly "reds." The fish swim so closely together that they are usually touching, and one appears to be pushing the other. Periodically one of the salmon darts after his companion, seizing him by the tail and endeavouring to hold him back, but more often they seem to be content to watch each other closely, and at times approach to within six feet of me. Now and again a smaller hen fish can be seen swimming near them. The cock fish in clear water can be readily distinguished by their bright tints of red and orange which are assumed for the spawning season. The hen fish, on the other hand, are black at this time, but their under sides still retain a trace of silvery colouring.

It is interesting, as I have mentioned in a previous chapter, to think that a number, at any rate, of these salmon have been a full twelve months in the river before commencing to spawn, for they begin to come from the sea in November and December, and it is not until the following winter that the ova are deposited. All this time, as I have pointed out, the fish eat no food of any kind.

Across the river from where I am standing a great commotion arises in the shallow water. Two cock salmon are evidently "hard at it " fighting, and the water boils under the powerful strokes of their tails. During the spawning time the male fish develop at the end of the lower jaw a large hook-like projection. The function of this has never, I think, been rightly determined. It is not to assist in spawning, for the cock does not turn up the gravel, but it is possibly a weapon of defence, and I have frequently seen salmon, during spawning operations, with wounds so pronounced that they showed even in the water at a considerable distance.

Crossing the river by a small bridge just beneath the spawning grounds, I can see a hen salmon lying only about a yard out from the bank, and in the shelter of a stone. 


\section{Wanderings of a Naturalist}

From time to time she appears to turn on her side, scooping up the gravel with her tail, and so covering with every stroke the spawn that is all the time being dropped. A cock fish, lying beside her, fertilizes the spawn as it is deposited.

As the sun dips behind the hills the salmon become more active, for they seem to prefer, when spawning, a dull day or the hours of twilight. Many fish can be seen, and in all directions the water is disturbed as the males rush with lightning speed upon each other. During the excitement of a fight I have known of salmon actually running themselves ashore, and with difficulty regaining the water. They are sometimes, too, hemmed in and imprisoned by the ice. Just above the spawning beds flocks of goosanders are swimming on the river, probably having nefarious designs on the ova. A water ouzel is swimming and diving energetically, though in too strong-running water to render this little bird open to suspicion of feeding on the spawn. How gracefully it swims in the rough water, or dives and walks along the stony bed of the river in eager search of aquatic larvæ. On one occasion, after perching on a stone, it flies out into mid-stream and plunges tern-like beneath the surface for an instant, its keen eyes having sighted some edible morsel in the water.

Though hidden from my view, the setting sun still shines on Lochnagar, transforming its upper slopes and snow-encrusted cairn to a beautiful rosy glow. On Beinn a' Bhuird a thin grey cloud is forming, to be tinged with pink as the sun strikes it from behind.

From the fir woods there comes the hoarse roar of a belated stag; otherwise intense stillness prevails, and the frost settles yet more closely, binding hill and glen in her icy grip. 


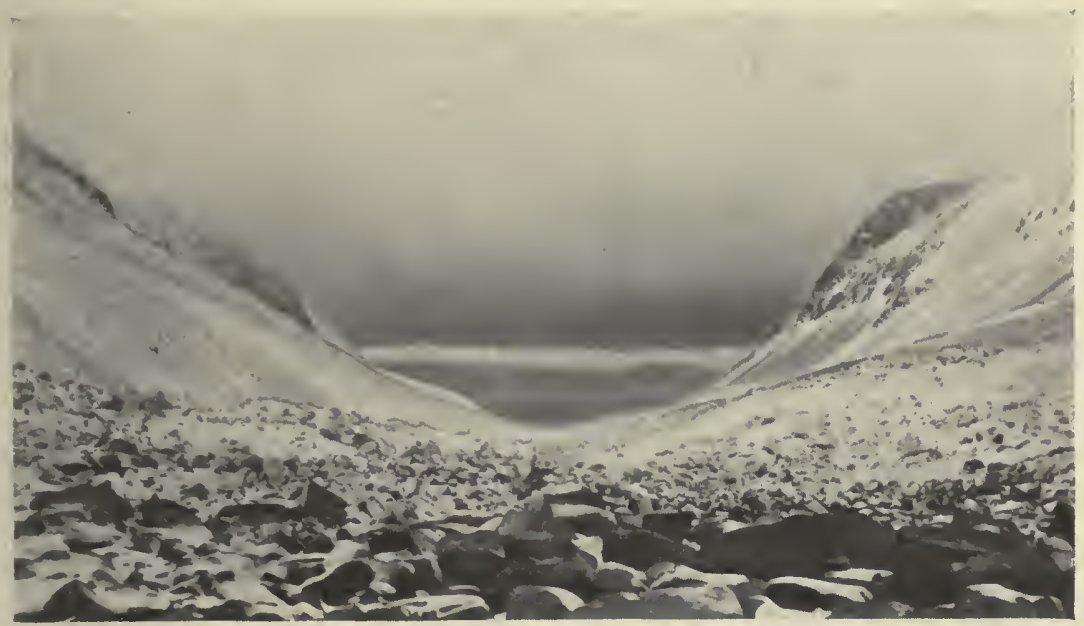

An Autumn Snowfall on the Lairig Summit.

Note the drifting snow at the foot of the Pass.

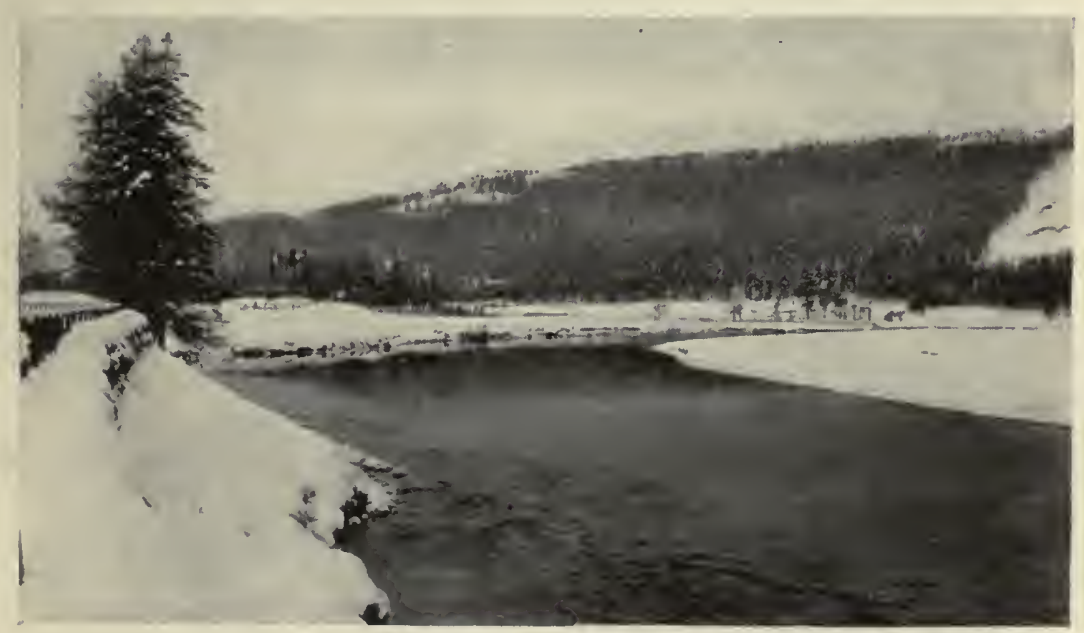

Salmon Spawning-ground on the Upper Dee. 


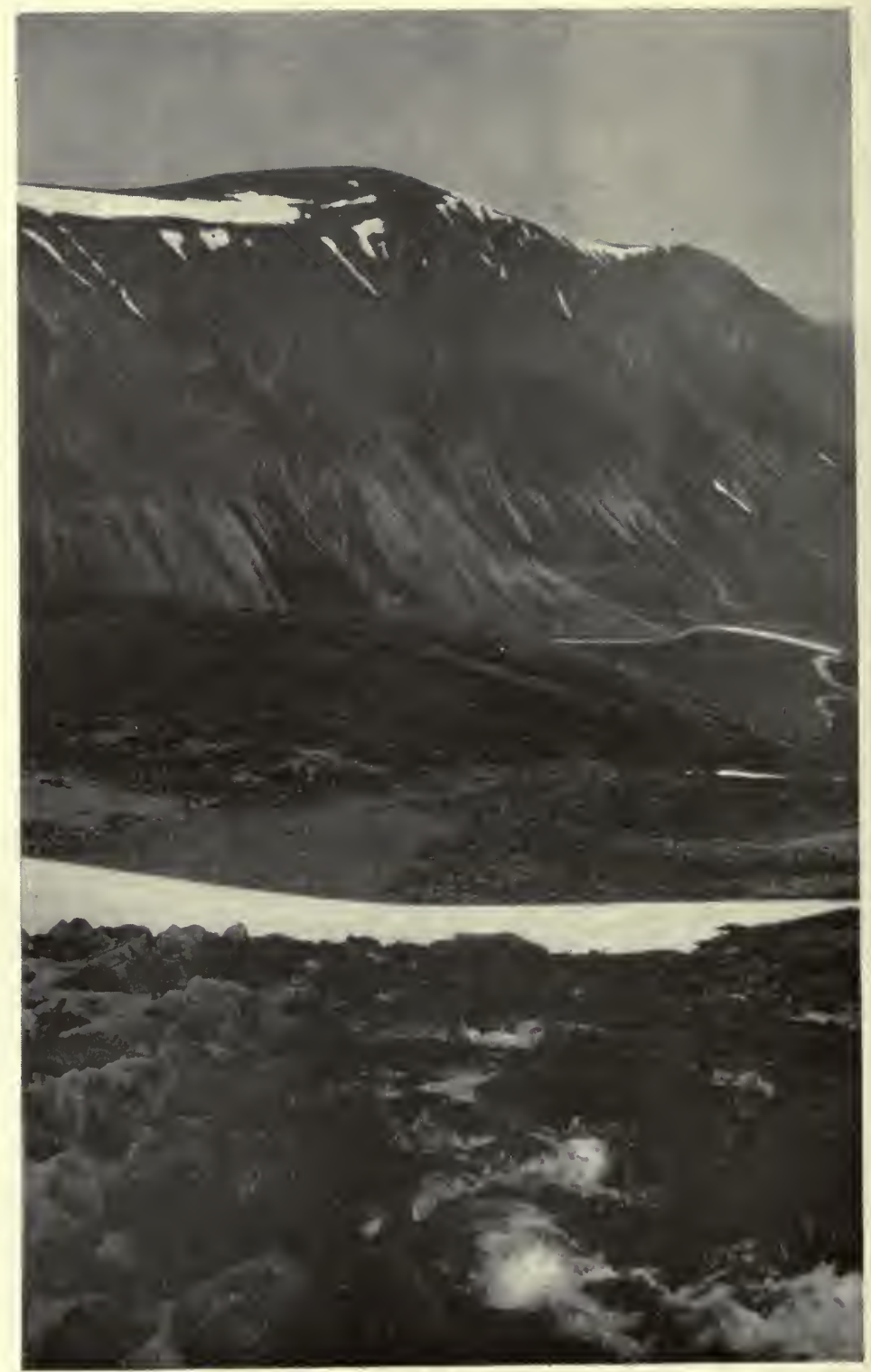

LOCH EINICH AND SGORAN DUBH.

Taken from near the source of Allt choire dhondail. 


\section{CHAPTER XXXII}

\section{SGORAN DUBH : AN AUTUMN SNOWFALL}

$\mathbf{R}$

ISING precipitously from lonely Loch Einich, and standing some dozen miles south-south-west from Aviemore, is the wild and gloomy hill known as Sgoran Dubh, or as it may be translated into English, "the Black Rock." The most westerly of the Cairngorm range of hills, it is at times mist-capped when its higher and more eastern neighbours, Ben MacDhui and Cairngorm, are clear to their tops, and even in June sunshine its precipices have a certain grimness. In early summer when snowfields still linger near the summit, the emerald green of the young grasses and blaeberry plants contrast pleasantly with these snows and with the blackness of the rocks, and the result is a blending of colours to delight the eye. Then again, in October, when the grasses become brown and the blaeberry plants turn to rich colours, the hill still shows this harmony of tints.

But one autumn, winter came far ahead of her time. Even in September snow lay deep on Sgoran Dubh, and big drifts were piled up in every sheltered hollow. And then before October was many days old a second and more severe snowstorm swept the hill. For close on a week the temperature continued below freezing point, and a strong and bitter wind brought with it powdery snow. Not only on the hill did the snow fali. Even the glen was buried for days beneath a mantle of white, and thus I found it when, shortly after mid-October, I paid a visit to the hill. After several days of snow and storm the morning opened with blue sky and little wind, and although 


\section{Wanderings of a Naturalist}

on the tops of the Cairngorms mist still lingered, in Rothiemurchus Forest the sun shone bright and warm. The way led up the Bennaidh, with clear rushing waters sparkling in the sunlight, until gradually the last of the fine old Scots firs was left behind, and an unbroken expanse of hill and moor met the eye. Some three miles from Loch Einich, and at a height of about 1,400 feet above sea level, the first snow was passed, and at the loch side (just over $\mathrm{r}, 600$ feet) quite three inches covered the ground, while thick ice encrusted the pools in the peat bog. A pair of grouse walked up the track in front of me, and were so confiding-or perhaps surprised - that they could scarcely be induced to take wing, and although the nearest tree was several miles distant, more than one chaffinch was flitting about the bothy which stands at the lochside.

Crossing the burn where it leaves the loch, I had a fine view of Coire Odhar-that big corrie at the head of Loch Einich. In summer more than one burn falls in a white cascade down this lonely corrie, but to-day these burns were fast imprisoned beneath snow and ice, and the corrie was an unbroken expanse of white.

To climb Sgoran Dubh from Loch Einich is, even in summer, a difficult business, for there are only one or two gullies which are accessible, and with a cornice of snow projecting many feet beyond the ridge these were to-day impracticable. A detour was therefore made northwards, where the hillside is less steep, and where a gradually rising ridge could be followed all the way to the summit. My way led me past Loch an-t-Seilich, a small loch concealed amidst great boulders in a slight depression, taking its name from certain dwarf willows which grow out over its peaty waters, and under whose shade trout may be seen to rise in the quiet of a summer's evening. To-day these willows had turned their leaves to a rich brown colour, which contrasted curiously with the surrounding expanse of white. Not far off there was borne on the north wind the roaring of stags, and soon a 


\section{Sgoran Dubh: An Autumn Snowfall}

number of hinds with two or three stags came into view beneath me, crossing the rocky hill face about Loch an-tSeilich. At a height of about 2,500 feet I came across a wellgrown mountain ash in a rocky gorge, where there was good shelter from every wind except the east. Beside this hardy tree-still bearing its leaves, withered by frost and snowwere great icicles, some of them the thickness of a man's leg, hanging from the rocks, while deep drifts of snow lay here and there around.

As I climbed higher the grouse were left behind, and I entered the ptarmigan country. The eagle was evidently hunting the neighbourhood, for the ptarmigan were extremely unsettled and anxious. Either singly or in packs they crossed the hill above me, their flight more rapid and powerful than that of a grouse. Flying noiselessly and looking extremely beautiful, with sky and unbroken snow as their background, the birds soared past me, some with never a movement of their wings. They had not yet assumed the complete winter plumage, and I had a fine view of a number of them a little later on as they fed on the young shoots of the heather. I know that certain authorities have been doubtful as to whether ptarmigan will feed on the common ling (Calluna vulgaris), but to-day-and not for the first time -I had undisputed proof, for I followed the footprints of the birds till they converged at an exposed patch of heather, the tips of which had all been picked cleanly off.

Notwithstanding the stormy and wintry conditions of the month of June, ptarmigan seemed to be more plentiful than usual that autumn, and this was also the case on the Monadh Liath Mountains, to the north of the Spey valley. Near where the ptarmigan had been feeding were the tracks of a hare in the snow, and a little farther on a fox had passed up the hill. Recently one of the stalkers of the Forest of Gaick came across a fox almost entirely white. He was anxious to have a shot at it, but stags were near, and a shot coming at that moment would probably have spoiled the stalk. 


\section{Wanderings of a Naturalist}

Reaching the ridge about the 3,000 -foot level, I found an average depth of two feet of snow covering the hill. On each rock and stone feathery ice crystals stood out, fern-like in form. Across the glen, Braeriach was mist-capped, but on its lower slopes the air was clear, and at times a gleam of sun lit up the snowy expanse. Contrasting strongly with the snow-clad landscape, the dark waters of Loch Einich lay almost immediately beneath me, while south-east from the head of the loch Beinn Bhrotain and Monadh Mor, in the Forest of Mar, stood out clearly, their summits nearly in cloud. In a wild snow-clad corrie about a mile to the west a number of stags lay in the snow. I was surprised to see them so far up in such Arctic weather, but that particular season the deer were very backward in coming into condition, and stalking was continued late, so that the stags took to the high ground for safety.

A thermometer exposed on the summit plateau showed 3I degrees Fahr.- one degree of frost-but the air was milder than earlier in the day, and the wind backing to the west brought with it driving clouds, so that the summit was soon shrouded in mist and all view obscured. I noticed that day for the first time the curious effect mist and a snow-covered hillside have on the ptarmigan's wings as it takes flight. The white wings are invisible and the bird appears to be flying with its wing-stumps alone.

Suddenly, only a few yards from me, there swept across this snowy wilderness, almost Polar in its dreariness, a darkwinged form, appearing gigantic in the mist. For a couple of seconds he was in view, then disappeared in the glooma golden eagle in his element. I have often wondered if the eagle, for days perhaps above the mist line, is always sure of his bearings-whether he knows exactly on what hillside he is hunting. Not that it would matter, for the eagle's domain is the high hills, and he is at home equally in storm or in sunshine.

The mist as yet did not descend far, and in the valley 152 


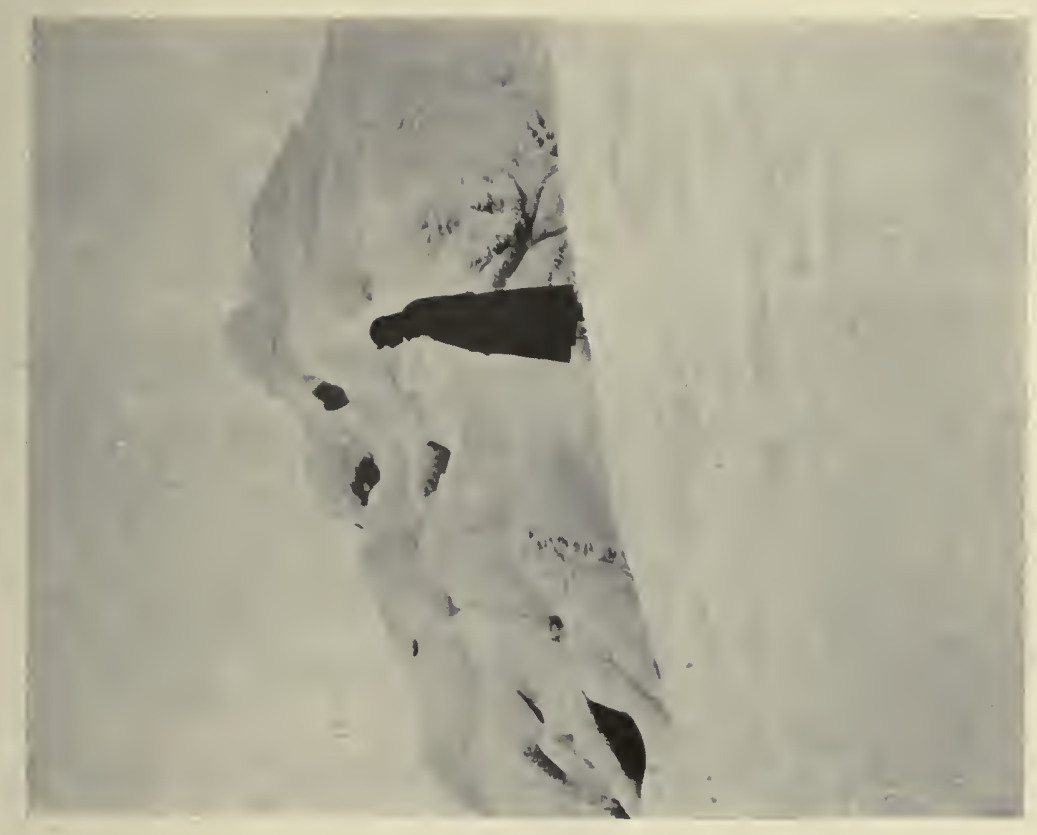

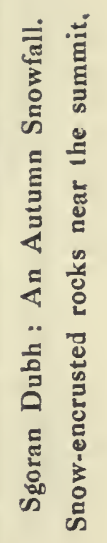

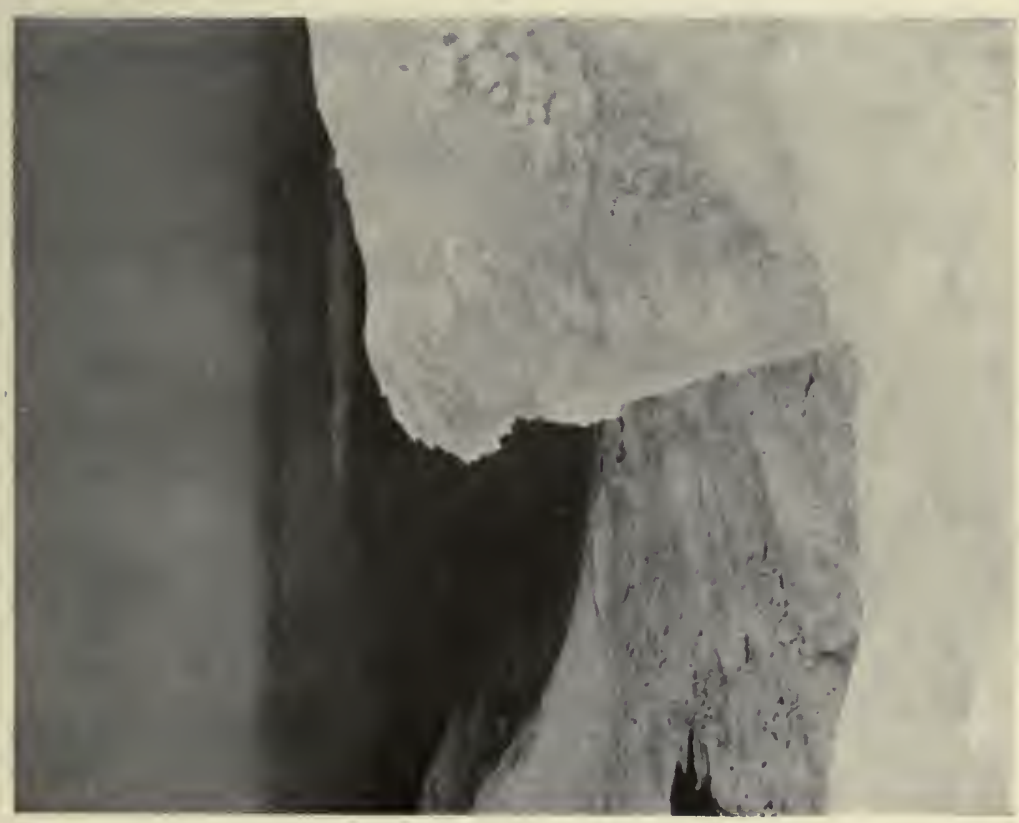

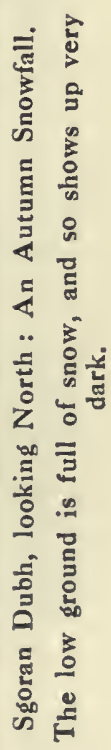




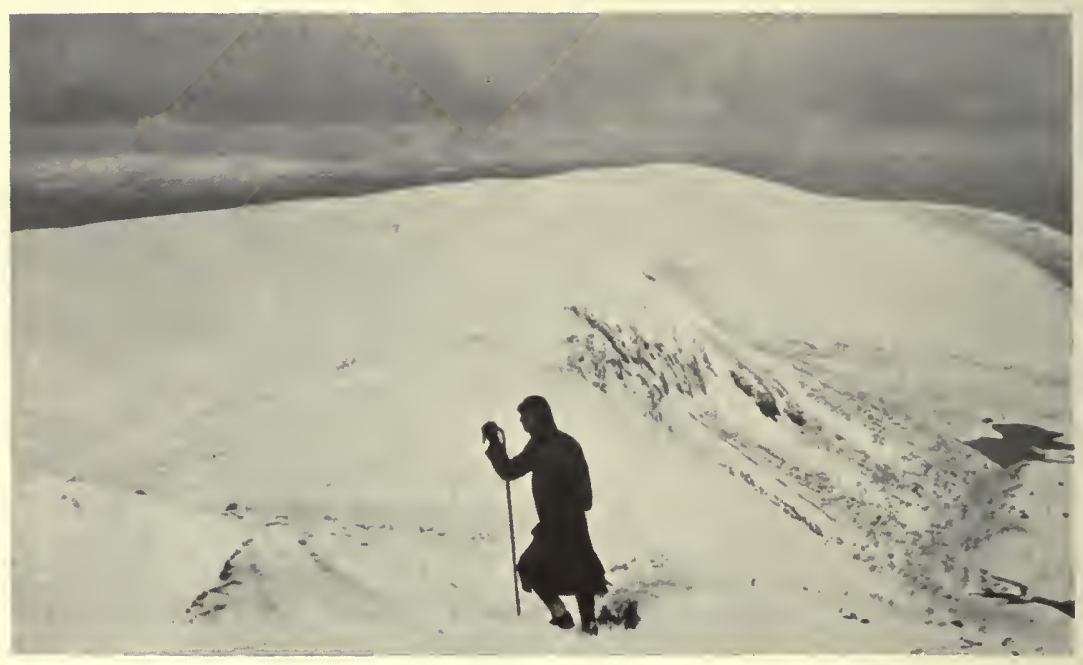

Sgoran Dubh: A Pilgrim in Snowy Wastes.

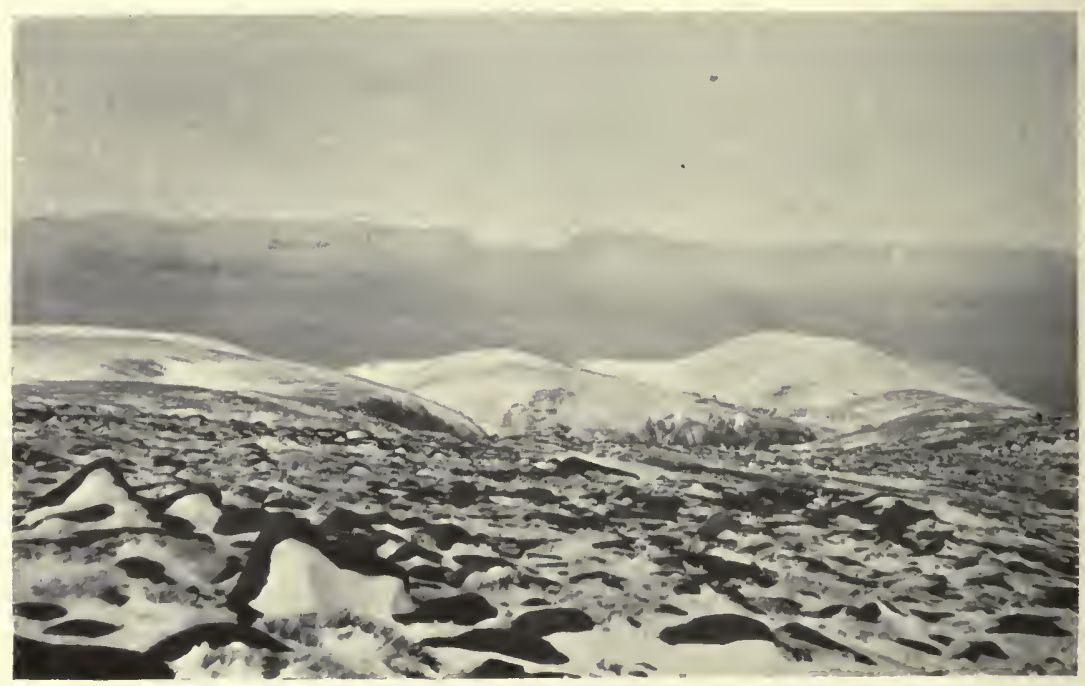

Ben MacDhui in September.

Looking across on to Cairngorm from the hill-top. 


\section{Sgoran Dubh: An Autumn Snowfall}

of the Spey the sun shone warmly, but on the high tops there was no sunshine, and night descended early, so that even the snow did not lighten the gloom. In the Forest of Rothiemurchus stag answered stag in the stillness of the evening, and away northward shafts of light pierced the sky as the Aurora flickered in the regions about the Pole. 


\section{CHAPTER XXXIII}

\section{BERRIES OF THE HILLS}

QUMMER is gone. Already the high tops have received their second coating of autumn snow, and the birches and hill grasses show golden and brown against the dark hillsides. It is now that the berries of the hills are at their best. As yet they are untouched by the frosts, and the tribe of the grouse and ptarmigan have not thinned their numbers, so that everywhere one may wander on the hills they are things to delight the eye by reason of their rich and delicate colouring.

Of them all perhaps the two best known species are the blaeberry (Vaccinium myrtillus) and the cranberry-or more properly the cowberry (Vaccinium vitis idoea). One frequently finds the two berries growing profusely together, and their season of ripening is nearly the same, though the blaeberry is rather the earlier of the two in forming its fruit. The blaeberry is one of the very few hill plants that is deciduous -that is, it sheds its leaves with the coming of each autumn. There is, to my way of thinking, no more delightful scent of the high hills than the aroma of countless blaeberry plants on a hot sunny day. The blaeberry, far more than the cranberry, is a true Alpine plant, and is found as high as between the 3,000-foot and 4,000-foot levels, though its fruit here is indifferent. The fruit of the blaeberry is of a dark blue colour. It is comparatively sweet to the taste, and the only berry with which it is likely to be confused is the crowberry (Empetrum nigrun), but whereas the leaves of the blaeberry are deciduous and delicate, those of the crowberry are heathlike and sturdy. 


\section{Berries of the Hills}

The cranberry-for it is always thus that the cowberry is named in Scotland-is a plant of the lower hills and pine forests rather than the high tops. In height it is considerably less than the blaeberry, and retains its sturdy leaves throughout winter. Its flowers are borne in a cluster at the apex of the stem. They are usually white, but may sometimes be found of varying shades of pink. Almost alone amongst hill plants the cranberry may be found flowering during every month of the summer, and even in late autumn, when there is little or no chance of the berries coming to maturity. The fruit of the cranberry is of a dark red, and one flower stem often bears quite a number of the berries, but the stem is sturdy, and is quite able to carry the weight of the fruit.

The leaves of both blaeberry and cranberry frequently turn to a flaming red at the approach of autumn. I noticed in Rothiemurchus during a recent summer that shortly after producing their leaves the blaeberry plants were almost everywhere attacked by a species of caterpillar and their leaves rolled up into unsightly withered balls. The disastrous fire which swept Rothiemurchus Forest in June, 1920, was largely aided by this fact, for the thick undergrowth of blaeberry plants, instead of offering a moist barrier to the flames, was almost as dry and inflammable as the heather itself.

A plant closely akin to the cranberry in its fruit is the bearberry (Arctostaphylos uva-ursi). Its berries are somewhat smaller than those of the former plant, and in colour of a slightly lighter red. The habit and appearance of the two plants are, however, entirely different, for the cranberry grows erect and sturdy, while the bearberry creeps prostrate over the hills. Although the two species may be found growing together, the bearberry is the more Alpine, and is usually met with on the high ground-at 3,000 feet and over. It is probably owing to this fact that its habit is prostrate, for it is thus better able to withstand the gales which so frequently sweep the high hills. The bearberry fruits late, and its berries 


\section{Wanderings of a Naturalist}

are frequently buried, while still at their best, beneath the first early winter snowfall. Frequently I have noticed, while on the high hills in winter with only a few inches of snow on the ground, that at almost every step I crushed some bearberries underfoot, their juice appearing through the snow and staining it red.

A plant little known on the hills is the great bilberry (Vaccinium uliginosum). The stems, unlike those of the blaeberry (or bilberry as it is known in the south), are stout and woody, and the leaves are more glaucous in colour than those of the common blaeberry. The great bilberry does not seem to be found so near the sea level as the common variety, nor does it reach to such great heights. Its berries, too, are smaller and of a more bitter taste. I have only exceptionally seen it bearing fruit on the Cairngorm Hills.

Perhaps of all the hill berries the crowberry (Empetrum nigrum) is the most alpine. It is extremely hardy, and seems impervious to cold winds and frosts. The leaves are small and of a dark colour, and are very zerophytic-that is, drought-withstanding. The flower is barely noticeable, but the berries are of almost similar size to those of the blaeberry, only black and sour to the taste. The shoots of the crowberry are eaten in winter by the ptarmigan, and probably the berries also.

The true cranberry, as distinct from the cowberry, which, curiously enough, everywhere in Scotland usurps its name, is known to scientists as $V$. oxycoccus. It is comparatively rare, and in its habit prostrate, resembling the bearberry rather than Vaccinium vitis idoea. Its berries are more transparent and inclined to yellow rather than red, and it grows mainly on boggy ground.

A plant widely different from any of those mentioned above is the cloudberry-or avern (sometimes spelt avron)(Rubus chamoemorus). It is in its habits comparatively local, but is usually found on or near boggy ground. I have seen it on the Cairngorms well over 3,000 feet up, but here it is $15^{6}$ 


\section{Berries of the Hills}

late in forming its flowers and its fruits rarely mature. A delicate plant is the cloudberry. It withers quickly when plucked, and its fragile white blossom has a short life at the best. The fruit before ripening is of a reddish colour, which, curiously enough, turns more to yellow-not to a darker red -as the berry becomes mature. When the plants grow in sufficient profusion-as in the Border district-the berries are gathered and make excellent jam, but I have never heard of them being used for this purpose in the Highlands.

Such is a brief record of some of the better known berries of the hills. The levels they touch in this country are, of course, insignificant as compared with the Alps, for, to take a single example, in the Maritime Alps the blaeberry certainly reaches an elevation of 9,000 feet, if not more. 


\section{CHAPTER XXXIV \\ BEN MACDHUI IN SEPTEMBER}

QEPTEMBER brings often mist and gloom to the high 0 tops. It is, more than perhaps any other month, a time of colour effects, when the hills appear overshadowed, as it were, with the spirit of mystery, and when their outlines are softened and the hills themselves are of a wonderful blueness. Winter has not as yet laid her hand on the Cairngorms, though as early as mid-August she may have paid a fleeting visit and covered the whole range inches deep in snow. But I do not recall ever having seen so much snow of the previous winter still remaining in the high corries in September as was the case this season of 1920; for the winter snowfalls from the west were unusually heavy, and the summer as a whole was cold and sunless.

There is no glen in the Cairngorms more attractive than that watered by the Luibeag burn. Ancient firs stand erect at the burn-side; many more clothe the face of the hills on either hand, and numbers still lie, their trunks bleached by age, where they fell during some of the great gales of the past century. The way up the glen of the Derry is long, but as one emerges above Loch Etchachan the wearisome walk is forgotten in the wide and varied view which lies spread out on every side.

Mist and sun strove for the mastery this September morning. On the rocky summit of Beinn Mheadhon the clouds rose and fell, and so clear was the air every stone was distinct on the hill. On Cairngorm itself clouds hung, but its namesake, Cairngorm of Derry, was clear to the top. Southward, sun and rain filled Glen Luibeag, the sunshine on the 


\section{Ben MacDhui in September}

driving shower shrouding the wild glen with mystery. Carn a'Mhaim, with green corries where stags graze in shelter from the west wind, was of a deep blue colour, and beyond it, and across the valley of the Dee, stood Beinn a'Ghlo, with mist near its summit. Curiously enough, the heather on the high grounds had bloomed earlier than on mid-Deeside this season, and around the Derry was already quite over. Just below the 3,000-foot line many plants of Azalea procumbens were passed, and I noticed that they carried an exceptionally fine crop of seeds. Here, too, were growing Lycopodium selago and Lycopodium alpinum, and crowberry and blaeberry plants extended even beyond this level, although at this great height they bore no fruit.

Beneath the wild Sputan Dearg of Ben MacDhui there lies a lochan which few have seen, for it is hidden in the very heart of the corrie and surrounded by big hills. Not a breath of wind ruffled the surface of the lochan to-day. One could see far into its gloomy depths, in which were reflected with uncommon and beautiful effect great masses of white cumulus clouds. Soon a shower swept down from the northwest, and across the waters of the loch a rainbow was thrown and persisted for some minutes. Amongst the rocks ptarmigan croaked, and a meadow pipit flitted up the hillside. The Lairig had that deep blue colour which one often sees in unsettled weather between the showers. On Cairn Toul the sun shone brilliantly, a few small clouds of a thin grey mist suspended in the air near the summit cairn catching its light. The Buidhe Aonach, as the southern spur of Cairn Toul is named, was in shadow, and the Devil's Point wrapped in gloom.

On Sgor an Lochan Uaine the mists lingered, and away at the head of the Garbh Choire mist and sun contended. I have never before seen the snowbeds of the Garbh Choire so extensive in mid-September. The main field wast as large as is usually the case in early August, and had not as yet even commenced to split up. Snow still lay in the corries 


\section{Wanderings of a Naturalist}

of Sgor an Lochan Uaine, and even in Coire Bhrochain of Braeriach, where it has usually disappeared by the end of July. On Monadh Mor, near the head of Coire Chreagach, two big fields of winter's snow were still undefeated, and indeed remained, this season, until the fresh snows arrived. As I reached the ruins of the sappers' hut, between the source of Allt nan Taillear and the summit of Ben MacDhui, a thin mist was enveloping all the hills and soon descended here also. Rain commenced to fall, and when the summit cairn $(4,296$ feet) was reached this had changed into soft snow, so that the outlook was by no means bright. The wind was almost due north but of little strength, and after half an hour or so the clouds gradually cleared. At first Cairn Toul appeared spectre-like for a moment, was blotted out, and then stood out once more. Soon Braeriach was visible and then Cairngorm, and with the passing of the shower the whole range of the Cairngorms was, for the first time, entirely mist-free. In the broad valley of the Spey bright sunshine and clear air showed up each house and village, but all around were dark showers and there was no distant view. Just north-east of Ben MacDhui summit a large snowfield still lingered, though relatively this was not so extensive as the field in the Garbh Choire.

An interesting discovery was made a few hundred yards from the summit cairn, on the north side of the hill, namely, the mummified remains of a redwing which had probably become exhausted in a storm during migration and had been buried and preserved in the snow. In June of that year, curiously enough, I had found, almost at the same spot, the well-preserved remains of a lapwing evidently just uncovered by the snow, which had melted only a few days previously. As the lapwing is essentially a bird of the low country, this unfortunate member of the species must also have perished on migration.

At a height of well over 4,000 feet two golden plover passed me just as the mist was commencing to clear. They 160 


\section{Ben MacDhui in September}

seemed uncertain of their bearings, and ultimately flew west across the deep ravine of the Lairig, making in the direction of the Moine Mhor-or Big Moss-to the westward of Cairn Toul, where they nest.

As I neared Lochan Buidhe mist and wet snow once more were sweeping across the plateau from the north, but the storm was short-lived and soon the sun was shining strongly. I have often wondered how came the name Lochan Buidhe, or, in English, the Yellow Tarn, to be given to the lochan. The tarn has the usual wonderful clearness that characterizes the waters of the Cairngorms, but to-day the grasses surrounding the lochan were already browned by the Arctic winds, and contrasted strikingly with the fresh green grass on the more sheltered slopes of the hill. It would thus seem that from these yellow grasses the lochan takes its name.

All plant life of the high tops has, even in fine weather, but a poor time of it, and during a cold and sunless summer the clan of the grasses are unable to ripen their fruit before being struck down by September frosts and snows. Near the top of Ben MacDhui hill grasses in sheltered hollows were this mid-September day still endeavouring to complete their flowering spikes, but they had not succeeded, nor indeed at that late date was there much chance of success.

Than these grasses the Alpine willow (Salix herbacea) is swifter by far in its growth. Already in its catkins were fully developed seeds, and the small green leaves were beginning to take on the yellow and brown tints of autumn.

Over almost the whole of the Ben MacDhui-Cairngorm plateau one comes across excavations where, in the years that are past, stalkers and others dug for Cairngorm stones. These stones were usually discovered where a vein of quartz disappeared beneath the ground, and some very fine specimens were from time to time found. The stones, or crystals of smoked quartz, are now very rare, since all the most likely 


\section{Wanderings of a Naturalist}

places have been carefully searched, but on one occasion I came across an unusually handsome crystal just showing above the gravel within a very short distance of the top of Ben MacDhui, and where many persons must have passed close to it.

From where the March burn drops in cascades from beside Lochan Buidhe into the Lairig a thousand feet below, an exceptionally fine view was had to-day of the Pools of Dee. There are four of these pools-two small and insignificant, two of a fair size. No breeze drifted across them, and I had the unforgettable experience of watching, through the glass, many trout breaking the surface of the unruffled waters-for the sunny interval and the dropping of the north wind were bringing forth a multitude of flies and the trout were taking full advantage of their presence.

Through the Lairig ptarmigan flitted, their snow-white wings things of beauty against the dark rocks and wastes of scree. One allowed me to approach to within fifteen feet, and I was able to admire to the full his sombre autumn plumage of lichen-grey.

It is rare indeed that the eagle is absent from the Lairig summit. To-day he beat up and down and across the Lairig looking for his prey, the ptarmigan, but having, while I watched him, no success with his hunting. Now soaring in spirals with the clear sunlight full on him, now closing his wings to shoot plummet-like towards the earth, the eagle exulted in the joy of perfect flight. Once I saw him do an unusual thing-namely, fly at great speed with rapid wing beats and clear-cut flight. I cannot recall ever previously having seen a golden eagle hurry; he indeed rarely moves his wings at all, and when he does so his wing beats are slow and almost-if one may dare say it of the King of Birds -laboured.

The valley of the Spey was reached at sunset. The air was clear and still, and in Rothiemurchus Forest pines and birches were scenting the night. Looking back, all the 162 


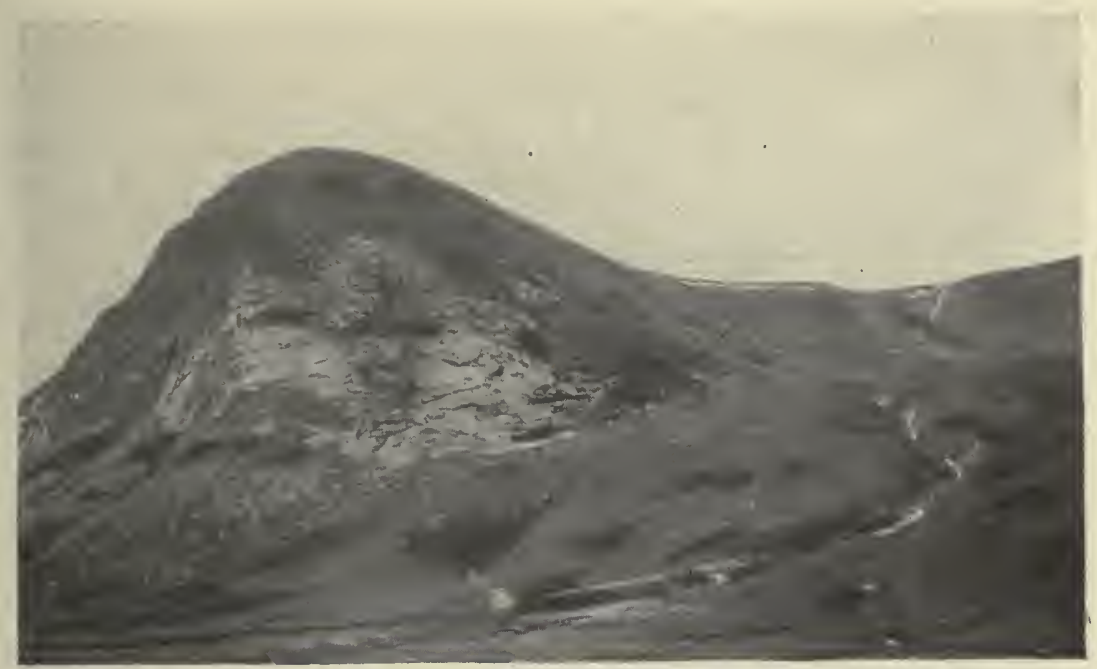

Ben MacDhui in September : Looking Westward into Coire Odhar. Just beneath the sky-line is a drift of fresh snow.

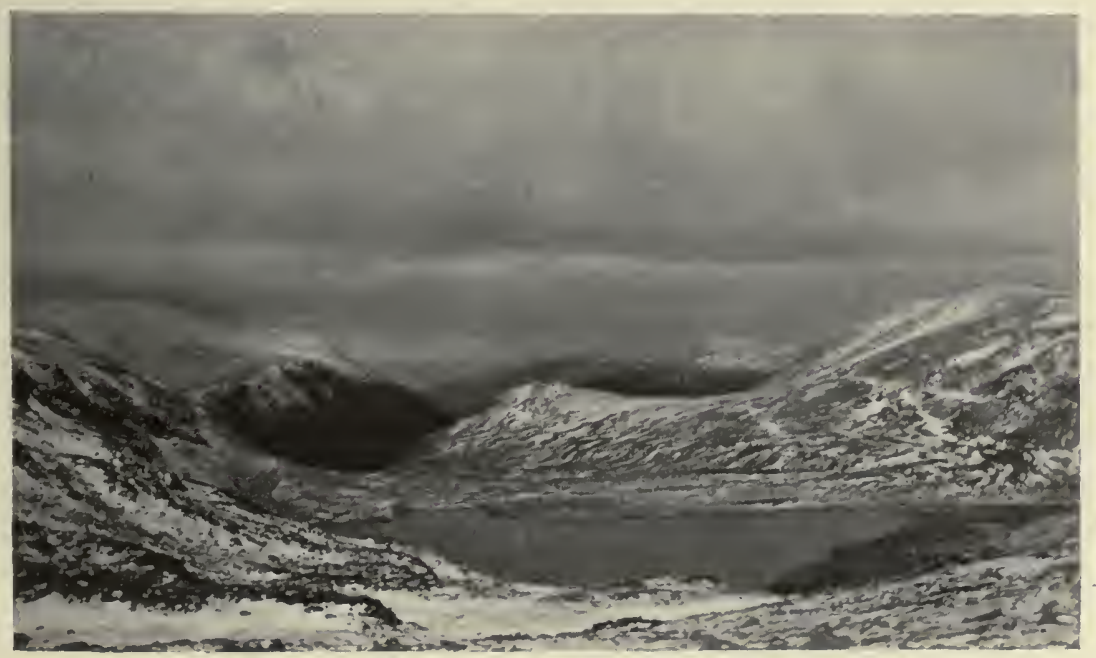

Loch Etchachan and Beinn Mheadhon. 


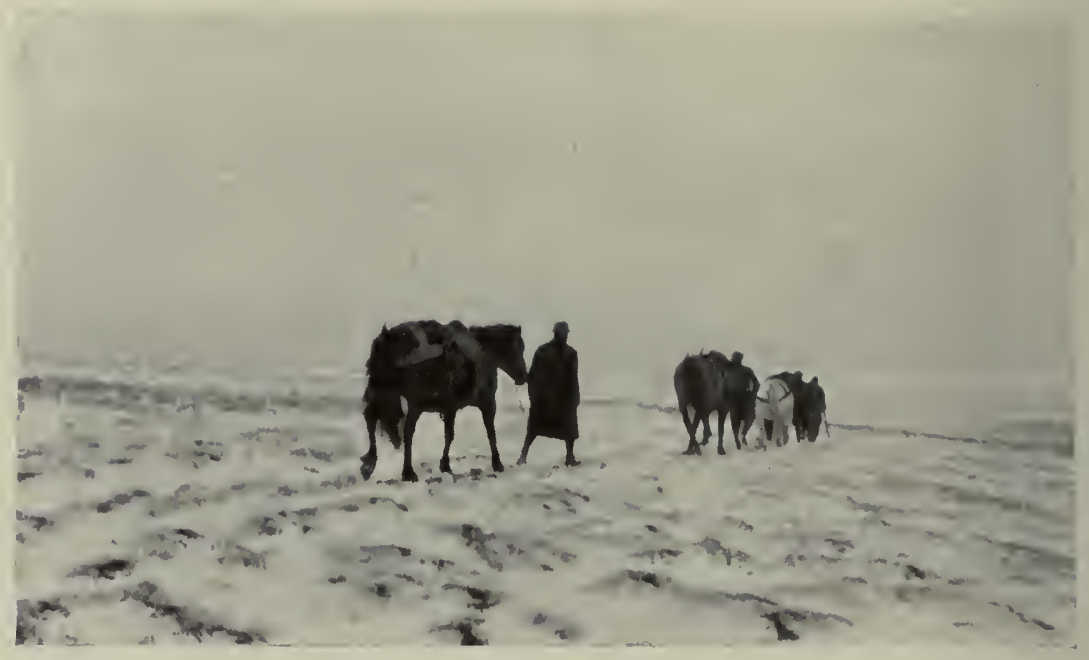

Across the snow-covered tops.

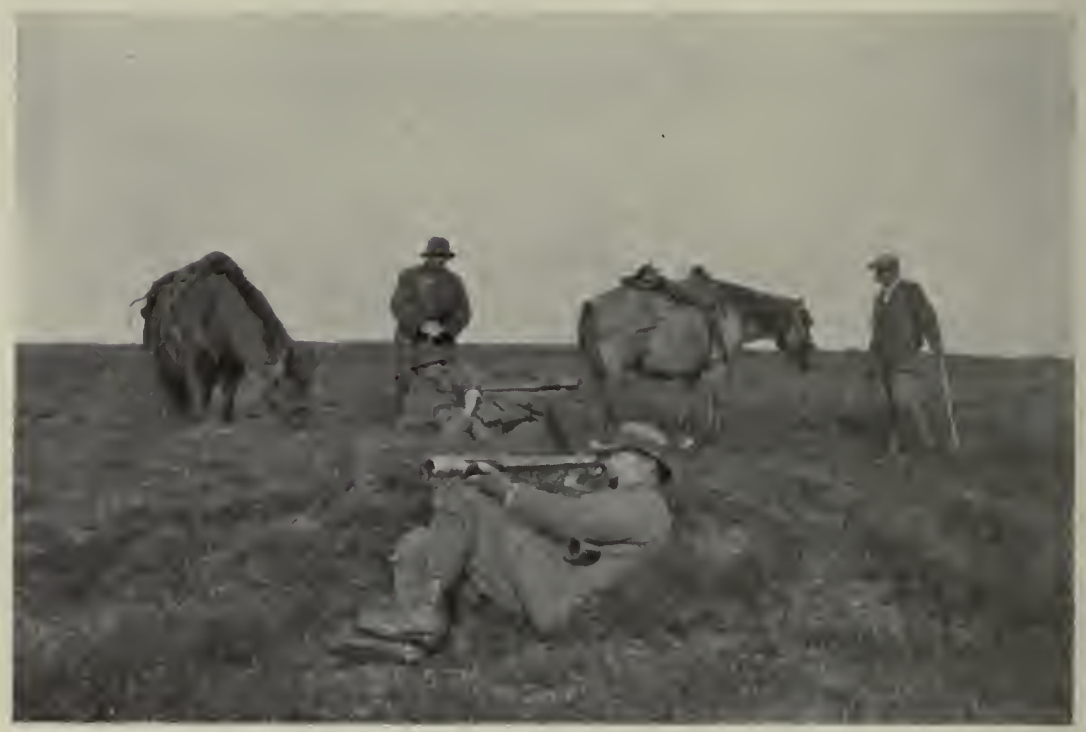

Spying the Corries.

AN OCTOBER DAY IN THE FOREST. 


\section{Ben MacDhui in September}

Cairngorms were clear to the tops. In Coire an Lochan of Braeriach several snow fields of the previous winter still lingered, and even in one of the westerly corries of Cairngorm the snow had not all melted. In the windless air the murmur of the Bennaidh carried far, and with the coming of night the stars shone forth, and over the countryside there formed a white frosty mist. 


\section{CHAPTER XXXV}

\section{AN OCTOBER DAY IN THE FOREST}

F OR days a south-easterly wind, blowing with the force of half a gale, had brought mist and rain to the hills. So low were the hurrying clouds, they almost descended to the remote stalking-lodge lying near the head of a windswept glen and fifteen hundred feet above the level of the sea.

Then one morning, when the stalking season had but three more days to run, the wind commenced to veer. Rain still fell in torrents, but the shift of the wind from south-east to west brought, as it almost always does, a lifting of the clouds.

By ten o'clock, for the first time for almost a fortnight, the tops of the high hills were showing, and as the stalkingparty left the lodge the wind, now fresh and a little north of west, gave promise of a fine day to follow.

In the bog migratory snipe crouched low. The burns were big. Each corrie showed a snow-white streak where a hillstream fell in headlong rush to the parent glen. From Loch Bhradain the boat had been swept by the flood; it lay several hundred yards down the burn, intact, though half-submerged.

Opposite us, in a steep and sheltered corrie, were two good stags and a number of hinds near them. One of the stags had rounded up all the ladies and, as we watched him through the glass, moved restlessly about, roaring from time to time. At length he lay down in a peaty hole, rubbing his head and antlers in the soft peat to cool himself, and subsequently scraping his peat-laden horns against his sides. The sun, breaking through the clouds, shone clear on the corrie, showing up each hind with great distinctness. 164 


\section{An October Day in the Forest}

The hinds soon began to feed out too far for the stag's liking; he rose, somewhat wearily, to his feet once more and rounded up his wives till they all fed together in a compact body.

Having reached Loch an Duin, at the county march between Inverness and Perth, we left the path and struck up the steep face of that rounded hill known as the Dun, or, as it is more commonly, though incorrectly, spelled, Doune.

Near the top of this hill one or two stags could be seen, and good beasts were expected to be found beyond the ridge, for the ground had been undisturbed for a month.

Near the track was lying the shed antler of an old stag, partly eaten. Stags are fond of chewing their cast horns, and in this connexion the following story is interesting. A farmer was greatly troubled by stags, which were ruining his crops. He was advised to shoot a couple and hang them up in a prominent position so that other marauders might take warning. This he did, but, far from the other beasts being terrified by the bodies of their former comrades, the very next day the survivors were seen eating the horns of the slain deer as they hung a little above the ground!

The wind had now veered into the north-west.

As we reached the high ground Loch an Duin lay beneath us, the wavelets on its surface glittering in the sunlight. A strong and uncertain wind was sweeping the loch, now from the south, now from the north, and many ripples crossed and recrossed its dark waters. Down the glen lay Loch Bhradain with Gaick Lodge showing in the distance.

We remarked on how green the hills were for this late season, but in the year when this chapter was written October was actually warmer than August, despite an almost complete lack of sun during its first ten days.

Near the top of the Dun grouse passed us, flying swiftly down wind, and by their terrified appearance showing that the eagle was not far off. From afar came the deep croak of a raven. The hill-top reached, each likely corrie was 165 


\section{Wanderings of a Naturalist}

cautiously searched-north, east, south, and west. But no stags were seen here, although on the far side of the glen several lots were spied.

From some scree beneath us a fox hurried, his long, bushy tail a conspicuous object as he made his way to safety.

Away southwards the air was very clear. Schiehallion, that serves as a landmark throughout almost the half of Scotland, was just mist-capped, and between us and it the Highland express could be seen hurrying south along the down-gradient between Dalnaspidal and Struan. Westward the clouds hung low, and from time to time misty showers swept across the tops.

Just beneath the hill-top, and sheltered from the wind, the conditions were summer-like. On the hill oppositeCunach-a number of hinds and two small stags were grazing on the skyline. One of the stags from time to time rushed in and rounded up the hinds in a lordly manner. But his lordship over the herd was probably of short duration, for by evening an older stag must almost certainly have driven him off and taken possession of the hinds.

A hurried descent brought us once again to the shores of Loch an Duin, and from here a very steep climb up Cunach was negotiated in under scheduled time-for valuable hours had been lost on the Dun, and the short October afternoon was drawing in. The going was easy-over recently-burnt heather-and I was shown a strip of ground burnt as recently as the past April, where the young heather plants were already growing fresh and strong. In this case the fire had not eaten far into the ground, with the result that the heather had come again from the root. Where the whole plant is killed and regeneration is dependent on seed, a number of years may elapse before any new growth is apparent. Curiously enough, the belief is prevalent amongst a good many stalkers that burnt heather never comes again from the root.

From the hill-top at least two good stags were seen just across the march between the two forests. The wind's direc- 


\section{An October Day in the Forest}

tion, however, was such that they fed away from us across the march into safety.

Crossing the plateau to spy the east-facing corries, one felt the charm of this fine autumn afternoon. Even at a height of over 3,000 feet the north-west wind had little sting in its breath. Eastward lay the great Cairngorm range. Braeriach and Cairn Toul were enveloped in dark clouds. On Monadh Mor mist rose and fell, but on the summit of Beinn Bhrotain the October sun shone clearly. We reached a bare ridge of the hill and cautiously looked into the dip beneath. Here a number of hinds, and with them a good stag, were feeding near some peat hags.

The stag, in chasing the hinds, floundered unwittingly into a slimy hole, sinking almost to the belly. Near at hand stood a second stag, roaring by himself; this beast may possibly have had the worst of an encounter with the stag now in possession of the hinds.

There was no cover near them; besides, the wind was unfavourable. A difficult shot was tried unsuccessfully by my companion, and as the evening was closing in and a long tramp lay between us and the lodge, a start was made for home. Down a deep glen, with hills rising high on either side, our way lay. On either hill face a number of stags and hinds were grazing. Above the hill-top an eagle sailed. Soon he was joined by his mate, the latter distinguished by her larger size. Close to each other for long the two birds soared, and unexpectedly a third eagle-also a hen-joined them. The pair now headed away westward, and at least twice their curiously musical yelping cry floated across to me on the calm evening air. Not for a number of years had I heard this cry, for the eagle is essentially a bird of silence, and in silent mystery sails above the corries of the great hills. Several times the eagles swooped down close to where the deer were grazing, as though to annoy them, and indeed they at times caused these animals considerable alarm.

A keen naturalist, and one who must have accounted for 167 


\section{Wanderings of a. Naturalist}

as many stags as any man now living, once watched a golden eagle swoop down upon a herd of stags. The alarmed animals thereupon ran across the hillside at top speed, and the eagle, full of his own importance, repeated his tactics on a solitary roe buck. But the latter was made of sterner stuff than his larger connexions, for in a moment he was on his hind legs striking angrily out at the surprised eagle with his fore feet.

As I reached the big glen Loch Bhradain lay before me with unruffled waters, on which numbers of trout were rising. It was indeed hard to realize that the end of the stalking season was almost here, so calm and mild the air, so green the hills. High above me, so that she appeared almost to touch the clouds, the solitary eagle still soared. After a while she made her way swiftly north, soon disappearing amongst the hills. Many stags were roaring in the corries. The rushing of the hill burns carried clearly across the quiet glen. Through the dusk were seen dimly the forms of the ponies carrying to the lodge the stags shot on another beat of the forest. The next day brought midsummer weather to the hills. From the stalker's point of view the pity was it came so late, but many stags owe their lives to the days of mist and rain which for weeks rendered them invisible and so secure. 


\section{CHAPTER XXXVI}

THE FLIGHTING OF THE WIDGEON

$\mathrm{D}$

URING the months of winter large numbers of widgeon visit our coasts, moving swiftly down to us from the sparsely-peopled regions of the Far North, where they enjoy, during the nesting season, the pale light of the midnight sun, and where their enemies are restricted, maybe, to the dashing Iceland falcon or the stealthy prowling steppe fox. The coming of winter is swift in these northern regions, and before the advent of October the long Arctic night is drawing in and the frost is gripping firmly the waters of the lakes and even of the sea itself. It is then that the widgeon set out on their long southward flight, and, journeying in great flocks before the northerly winds, arrive on our shores with the approach of winter. But though at first these travellers are friendly and confiding, the ceaseless persecution of the shore-gunner causes them, in a short space of time, to become wary and ever on the alert, so that they spend the hours of daylight on the open sea, venturing to the mud-flats to feed only when darkness is settling on the waters to hide them from their enemies. Few localities in Great Britain are more suited for the requirements of shore birds than the great mud-flats of Holy Island, off the coast of Northumberland, and it is here that the flighting of the widgeon is, for the naturalist as well as the shore-gunner, a thing of peculiar interest.

Dawn had not yet tinged the eastern horizon one January morning as we left the castle of Lindisfarne and made our way to the water's edge, where a boat was ready to cross with us to the opposite shore of the estuary mouth. The 


\section{Wanderings of a Naturalist}

wind had dropped, but the roaring of the surf on the beach was borne across on the quiet morning air, and at times the sad cry of a curlew came sharply out of the gloom. Soon snow commenced to fall softly, but the shower passed as we rowed out into the night. As we gained the opposite shore the sky was lightening eastwards, and we made our way at once to a certain part of the sand dunes which the widgeon are in the habit of crossing with each dawn as they make their way from their feeding grounds to the open sea. Once the quiet was broken by the musical twittering note of a bartailed godwit, as this curlew-like bird passed unseen over our heads; but for some time we waited before hearing the curious, whistling cries which heralded the approach of the widgeon hosts.

For the writer, this early-morning scene had an especial charm. The strong smell of salt permeating the atmosphere, the sky brightening imperceptibly and showing in places grey snow clouds far out to sea, the intense calm and stillness over all, these were things which appealed strongly to one who loves the ever-changing moods of Nature.

There were many birds in that first flock of widgeon which passed rapidly overhead-certainly hundreds and perhaps over a thousand made up the first company. Flying out of gunshot, and at the speed of an express train, the birds were visible in the dim twilight for a few seconds only; but almost immediately, with sharp, excited calls, pitched in varying keys, a second flight passed over us, flying this time in one long single line. The soft murmur of many wings proclaimed the approach of a third flock of great size, though in this instance the birds themselves were for the most part silent.

And so company after company of widgeon passed overhead, until the daylight had strengthened and the snowcovered lands to the westward, with Cheviot in the far background, showed themselves to our view. The tide ebbed rapidly, and the shore was thronged with waders of various species. Redshank moved restlessly from point to point, 


\section{The Flighting of the Widgeon}

uttering shrill, penetrating cries, and flocks of dunlin wheeled and turned as one bird, showing, as they always do, the most remarkable skill in performing complicated evolutions. But the most interesting bird was the bar-tailed godwit, a winter visitor to our shores, and having an extremely wide range during the winter months. It is numerous along our northeastern coasts and is found on migration in France, Spain, and Switzerland. For some months the godwits remain on Holy Island, but with the coming of full spring the migratory impulse calls irresistibly, and they set out on that flight of thousands of miles to the Siberian tundras, where, even during the hottest July day, the ground is frozen fast a foot beneath the surface. It was now full daylight, and with an approaching snowfall from the Farnes the wind freshened and companies of wild geese flew in strongly from the sea. At times their flight formation was V-shaped, but this formation was irregular, and often the birds spread out into a long, thin line as they rapidly winged their way to the landward end of the bay to feed on the floating marine grass. Oyster-catchers, uttering their clear distinctive whistle, moved backwards and forwards, and a solitary great northern diver was actively engaged in fishing in the channel. These divers remain under water for even longer periods than the cormorant, and it is quite remarkable what a distance they will swim submerged when' alarmed.

From Lindisfarne Castle it is possible to sweep the whole of the bay with the glass, and just at the edge of the breaking surf could be made out a vast number of widgeon-the hosts we had seen passing over at dawn-riding buoyantly on the waves and being at times half-submerged by a heavy breaker. Portions of this great assembly flew restlessly backwards and forwards, but no new-comers appeared on the scene. In the comparative security of the open coast these companies of widgeon pass the day, waiting idly till the fall of another winter's night, when they will set out on their return flight to the west where their feeding grounds lie. 


\title{
CHAPTER XXXVII
}

\author{
CROAGHAUN OF ACHILL
}

$\mathbf{R}$

ISING sheer from the Atlantic on the extreme western coast of Ireland-it is, indeed, almost the most westerly point of Europe-there stands, bare to the four winds, the fine hill known as Croaghaun. In the Scottish Gaelic I think it would be spelt Cruachan, and, indeed, there is a certain resemblance between itself and Beinn Cruachan in Argyll.

For days-weeks even-on end, Croaghaun in winter wears his mist-cap, but on this morning of mid-winter the clouds were high, and-a rare thing for the Atlantic seaboardscarce a breath of wind stirred. As a naval companion and I made our way along the southern shores of Achill, the spray from the great Atlantic breakers hung, mist-like, in the quiet air, and, indeed, penetrated quite half-way up the broad hill of Meenaun, filling its dark precipices to a height of close on a thousand feet with grey vapour. From many villages the smoke of peat fires rose, to hang over the townships in a layer of thin blue smoke mingling with the salt spray. Passing the village of Dooagh, where primitive conditions still prevail, and where in certain of the cotters' dwellings window and chimney are absent, and the peat smoke escapes through a hole in the roof, we struck up the shoulder of the hill and made our way to the summit, along the top of the rocks which shelter the dark waters of the lough Corrymore. To-day no ripple stirred the surface of the lough, but its peaty waters were impenetrable, and no rising trout broke its surface. Many plants of dwarf juniper clothe the hillside, and on the trailing stems of the bearberry red fruits were still showing. 


\section{Croaghaun of Achill}

Beneath the rocks saxifrages were still green, and there was little to show that mid-winter was here.

Even on the hill-top--2,200 feet above the sea-level-not a breath of air stirred, but by now on Slievemore, a few miles to the eastward, a thick cloud was resting, and from time to time across the hillside beneath us thin vapours floated. Out to sea the air was clear, and far to the westward the wintry sun was shining. Through the mist-cap, which by now was beginning to settle on the hill-top, we could see, lying out into the ocean, perhaps ten miles to the north-west, the tiny Black Rock, with its lighthouse. I think that of all British lights this must be one of the most isolated and difficult of access. Even to-day, when the air was still, the surf breaking on the Black Rock was tremendous, and at times almost reached the lighthouse itself.

On the summit of Croaghaun one is, indeed, on the fringe of the world. Here one looks seaward, with nothing between oneself and America. Here, during the season of winter, the Atlantic storms rush with terrific force over the hill-top, so that the wild goats seek what shelter they can amongst the dark cliffs, and even the raven does not venture abroad. As we stood by the summit cairn the deep roar of the swell as it thundered on the rocks was carried up even thus far, and on the sheltered shore of Keem green-tipped waves were falling with measured rhythm. Westward the hillside falls away down to the sea in the form of a great precipice, where wild goats cling, and where in former times the sea eagle and golden eagle bred. Indeed, it was only a few years back that the last golden eagle's nest was seen on these rocks.

Since the mist lingered on the summit I made my way down to the western spur of the hill, which was free of cloud. Gradually, north and south, the sky cleared and the sun shone brightly on sea and islands. The Black Rock Lighthouse showed plainly, and the spray from the surf as it was gradually wafted to leeward-for a slight northerly wind had sprung up, ruffling the ocean-was tinged with pink. Away 


\section{Wanderings of a Naturalist}

beyond the Black Rock lay the two low islands known as Innishkea South and Innishkea North, and between them and the mainland of Blacksod Point a skiff was sailing her way out to the islands, the sun shining full on her brown sails. Very primitive are the people of these islands, where, till recently, they were accustomed to elect a king, having in his hands absolute power.

There is no peat on these islands-it has to be carried out in boats from the mainland-and to-day near the straggling village I made out through the glass what I took to be stacks of peat standing near the shore. On Innishkea North I could distinguish the whaling station, idle during the war, and away beyond that again and bearing east, the watch-tower of Blacksod Point. Far to the north Eagle Island and its lighthouse caught the rays of the sinking sun which was tingeing the spray from the Atlantic surf.

Sailing on powerful wings across the precipice above me was the dark form of a raven. Every now and again he shot into a cleft in the rock, and I imagine he was inspecting his nest. From a rocky pinnacle a peregrine sped out over the sunlit ocean with magnificent flight. A little later on I came across him perched on a rock and enjoying the unwonted sunshine and quietness of the day. Through the glass every feather showed distinct-his white cravat and his beautiful plumage. His keen eye, glistening in the sun, scanned the rocks and sea beneath him, and on my approach he sailed out, and on wings which remained absolutely motionless crossed to a far point on the hill, where he alighted on a steep, rocky slope.

Everywhere along the foot of the cliffs the powerful Atlantic swell was leaping with slow and ponderous motion, giving one the impression of tremendous strength, and in the ear was always the roar of the water. I wondered where these great waves had their birth-I imagine in mid-Atlantic, a thousand miles to the south-west, perhaps even more.

Amongst the dark caves of Croaghaun the grey seal 


\section{Croaghaun of Achill}

brings forth her young, and even the rare Greenland seal has sometimes been seen here, for he is occasionally carried on an iceberg far to the southward of his usual quarters and comes to land along the western shores of Ireland.

Over this wild hill the tribes of the wild geese and plover often pass on their northern and southern flights and come to rest on the low ground in the shadow of Slievemore, where they find food in plenty and rest undisturbed.

As the sun sank beneath the ocean new country showed itself which had hitherto been hidden in the haze. A dozen miles to the south, Clare Island, with its high hills, caught the sun. Then away beyond it again there lay the hilly Isle of Innishturk, and still farther to the southward the long, low island of Innishboffin, with its bold headland-the Stags of Boffin-breaking the force of the Atlantic. The meaning of Innishboffin is said to be "the island of the white cow," for in the centre of the isle there lies a lough, supposed to contain a fairy cow, which from time to time shows itself.

Bearing farther east the hills of the mainland stood outCroagh Patrick, with the church standing on its summit, over 2,000 feet above the sea, and beyond it the chain of Connemara hills, known as the Twelve Pins, or Twelve Bens, as, I believe, the name was originally written.

Wherever one might look no tree met the eye in all this country, and yet in former times vast forests clothed these boggy plains and hill slopes, and even to-day the relics of this great colony may be seen in the tree stumps and roots which are unearthed in digging the peat.

South-west the sky now took on a tinge of pink, each fleecy cloud being rose-tinted in the light of the setting sun. A firm line showed where sea and sky met, for the air was now of an exceptional clearness, and in the north wind there came the breath of frost. Across the hundreds of miles of ocean that lay spread before me no ship passed: the waters were given over to the seal and the quick-flying solan and the cormorant. 


\section{Wanderings of a Naturalist}

A pair of choughs, calling querulously, made their way across the hill to their roosting-place, and soon the full moon, gradually asserting herself, shed on the breaking swell and still waters of the deep Atlantic her silvery rays, so that the whole world of hills and islands became transformed, and the flashing rays of the lighthouse on Clare Island, shining far across the dark waters, seemed insignificant beside the brilliant moonlight. 

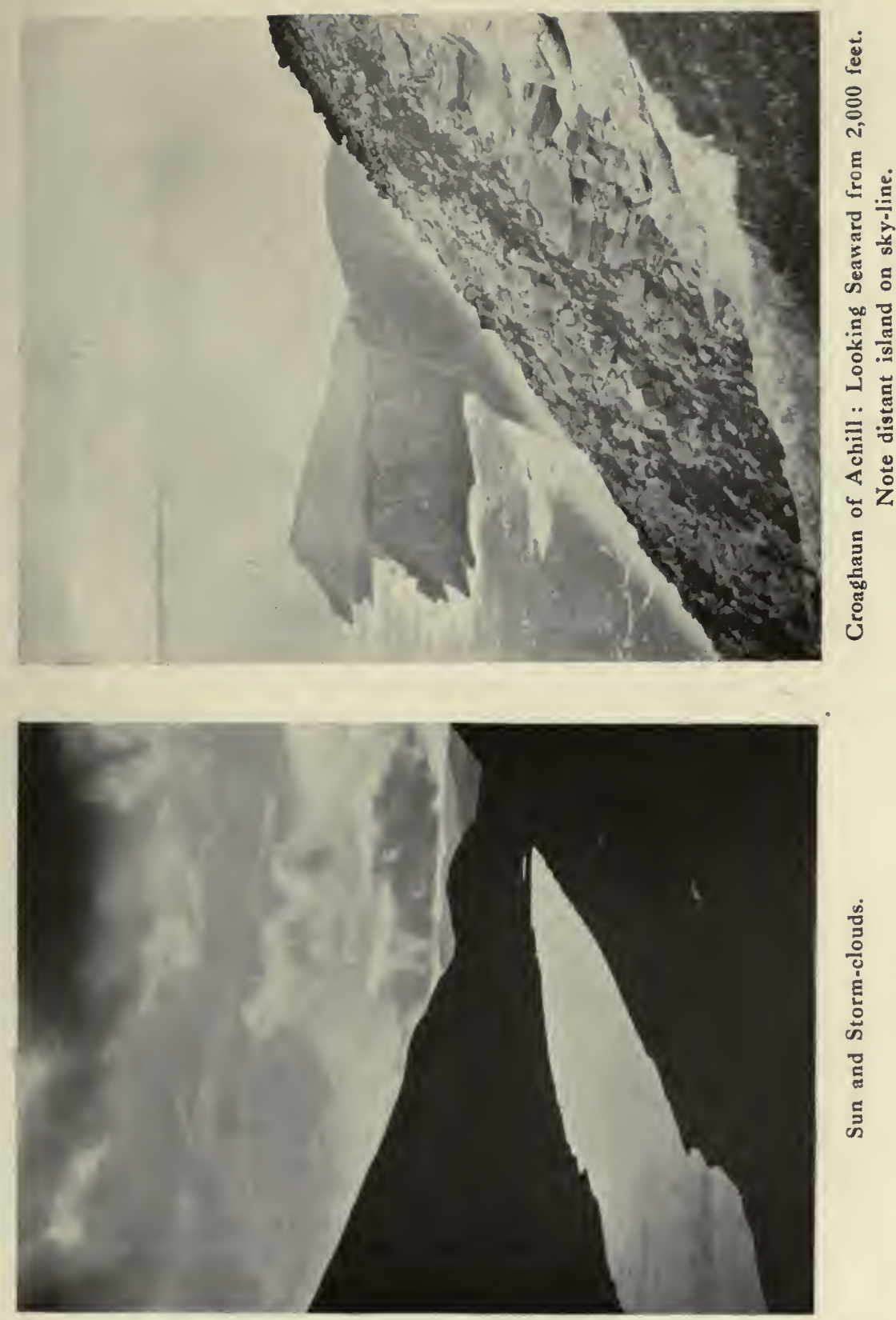


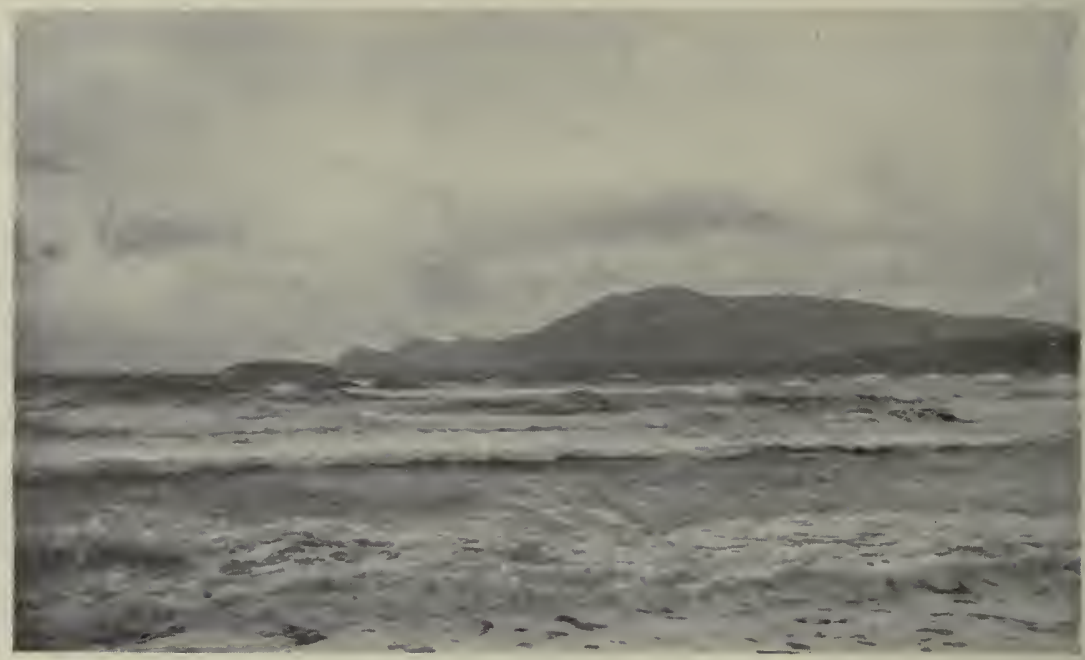

Croaghaun of Achill.

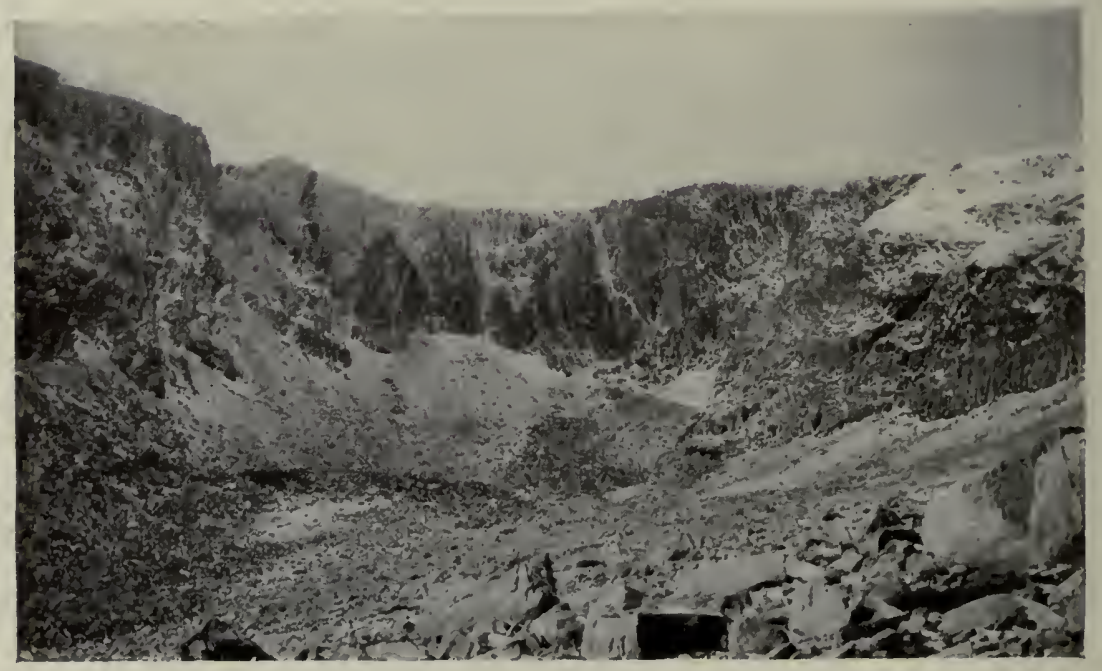

Garbh Choire Mhor: The Corrie in October.

Showing the old snowfields with a powdering of fresh snow over them. 


\section{CHAPTER XXXVIII}

GARBH CHOIRE MHOR : A CORRIE IN THE CAIRNGORM MOUNTAINS

T YING in the heart of the Cairngorm Hills, where no eye can see it from a distance, is the Great Rough Corrie, or, as it is known in the Gaelic speech, Garbh Choire Mhor. (Pronounced Garav Korry Vor.)

I think that of all the corries of this wild mountain range it must be the most gloomy and remote; yet it holds, especially during dark days of storm, a great charm and one that is peculiarly its own. I know the corrie at all seasons of the year, and I think that in early November, when late autumn is merging into winter, and when the high tops are snowsprinkled, it may be seen at its best.

The mists are often on the hill-tops these short days of late autumn, and descend into the corrie, filling it with grey vapours that sway and eddy with the uncertain gusts of wind. Darkness falls early in the corrie, for on every side the big hills rise, and in the corrie itself the autumn sun never shines.

Immediately south of the corrie Cairn Toul rises steeply, with mile upon mile of granite scree, devoid of life and desolate save when the eagle, in his hunting, passes across the hill face. Westward is a sheer precipice, at the foot, of which lie the eternal snows of the Garbh Choire, small and peatstained after a hot summer, still large and unbroken after a summer of cold and wet. North of the corrie is the great hill of Braeriach, with its corries and precipices-Coire Ruadh, or the Red Corrie; Coire Bhrochain, or the Corrie of the Porridge. Then there is that wild corrie where the Dee 


\section{Wanderings of a-Naturalist}

falls headlong in white spray-dazzling in a day of June sunshine, dark and sullen after October storms. But it is only during a part of the year that the Dee is seen; after November the waterfalls are held firm in the grip of frost and snow, all save one small fall, which I have never seen icebound. The name given to this corrie is Fuar Garbh Choire, or the Cold Rough Corrie. I have often wondered that this name should have been given to it, facing as it does due south. If any corrie deserves this title it is the western end of the Garbh Choire Mhor, where even in June the sun shines only for a few hours and where the snow never disappears.

In the corrie plant life abounds, and that creeping alpine plant Azalea procumbens carpets the gravelly slopes with its small, richly-coloured flowers during long June days. I once found it everywhere flowering in the early days of October, though this is quite exceptional. Amongst the granite boulders there grows the parsley fern, with delicate curly fronds contrasting strikingly with the lichen-plastered rocks. Other Alpine plants are in the corrie-Gnaphalium supinum, more than one species of Carex, Silene acaulis, Lycopodium selago, the Alpine variety of juniper, Saxifraga stellaris, and many others.

The tribe of the ptarmigan have their home in the corrie. Often they may be seen on white, silent flying wings crossing from one feeding ground to another. At times, flying for their lives from the eagle and with a following wind, they hurry, at a speed greater than an express train, over the high tops, halting only when across on the Speyside ground. But when the eagle has passed by, they return, skimming the hillsides and moving always in silence.

During the autumn months the corrie hears from time to time the sad whistle of the golden plover as these birds of swift and clean-cut flight move across on their migration. At times, too, the soft though far-carrying whistle of the hill dotterel may be borne across on the breeze. The eagle is 178 


\section{Garbh Choire Mhor}

often in the Garbh Choire: I have seen him sail up the corrie on motionless wings, facing a blizzard of driving snow so fierce that I could scarcely look into the wind. The peregrine falcon I have never once seen in the corrie, though he may sometimes pass here, nor the sable raven of stately flight. The eagle would doubtless nest in the dark precipices were it not that in April, the season of her building, they are entirely filled with snow. Nor does this snowy covering commence to melt until the latter part of May, when the burn of the Garbh Choire comes rapidly into spate and with milky waters-they are never peat-stained here-hurries, foaming, down the corrie to meet the Dee in the Lairig beyond it.

During the spring of 1920 the snow was later in leaving the corrie than I ever remember. Even in June the western and most precipitous end of the corrie was entirely white, and when elsewhere the wind was warm, to leeward of this great snowfield the air had an icy touch. So fierce was the wind at times that the water from the melting snow was lifted high into the air, and falling on the plateau above the corrie in the form of rain, seemed strange indeed as descending from a sky of cloudless blue.

Not many stags are in the corrie at any time. In October, on misty days, when all about the corrie is wrapped in gloom, their hoarse roarings may be heard, especially towards nightfall. They are of a wonderful charm these autumn nights, when after sunset the Aurora plays about Braeriach, lighting up the Lairig and all the sky away to the northward; when the pale moon, high in the heavens, floods the Garbh Choire so that its snows seem all the whiter in her rays. Then, maybe, the fine weather goes from the hills and the west wind rushes across the high tops, eddying around the precipices and surging about the black cliffs of Coire Bhrochain. And on the arms of the gale there may come squalls of rain and sleet, hurrying across from the Atlantic in clouds that are black as night. 


\section{Wanderings of a Naturalist}

The Garbh Choire is at such times a place of gloom and the home of the storm spirit. When the squall is at its fiercest the sky, maybe, is of a sudden lit up by a brilliant flash of lightning, and there follows almost on the instant the thunder which reverberates across the corrie, flung back from one precipice to another. But these quickly moving storms are of short duration, and soon the sky clears to a steely blue, while Braeriach and Cairn Toul lose their mistcap, and eastwards across the Lairig Ben MacDhui stands out once more, now powdered with snow as a result of the short-lived storm.

There are days, in summer, as in autumn, when not a breath of air stirs in Garbh Choire Mhor. At times such as these the great corrie is filled with a wonderful silence-the silence of the hills. From afar, maybe, comes the murmur of a distant waterfall, a sound in keeping with the grandeur of the corrie.

As winter lingers long here so is she early in setting her mark on the corrie. For days the snow-that in the glens beneath comes as rain, or perhaps sleet-falls softly, and with the clearing of the skies the frost binds the ground. Slowly but inexorably the burns are imprisoned-the ice grips them even where they are most rushing and turbulent-and on Lochan Uaine the young ice creeps out from the shallow water at the loch's edge.

Thus it is that, when in the valley of the Dee autumn still lingers, and the larches are as yet golden with autumn tints, Garbh Choire Mhor is altogether a country of ice and snow -of polar grandeur and Arctic sternness.

So it will remain through the long winter months-a place wild and desolate, and lifeless save for the ptarmigan that people it, and the eagle that at times visits it at his hunting. 


\section{CHAPTER XXXIX}

\section{THE ARAN ISLANDS : AN OUTPOST OF IRELAND}

YOME twenty-five miles to the westward of Galway, and rising from the deep waters of the Atlantic, is a group of three small islands, by name Innishmore, Innishmaan, and Innishear. I think that on these islands more primitive conditions prevail than in any part of Ireland, for the islanders have little communication with the mainland, and many of the older inhabitants have never left their island homes. Innishmore, or the Great Island, is the largest of the three. In length it extends to some eight miles, but at its widest point is scarcely two miles across. Its principal harbour is Kilronan, where the well-known Galway steamer, ss. Dun Engus, calls on her eagerly awaited trips, and where there is much fishing activity during fine weather, both in summer and winter. A couple of miles to the southward there lies the small rounded island spelled in the charts as Innishmaan, but more correctly Innis Meadhon, or Middle Island. This island is the most.primitive of the group, and its people are said to be the most simple and unspoiled, while their Gaelic is held to be the purest to be found throughout Ireland. Bearing south again, one comes to the smallest island of the group, known in the Erse as Innishear, or Eastern Island. From the nearest point of the Clare coast this island is scarcely five miles distant, yet there is little communication with this part of the mainland.

I shall not readily forget the first occasion on which I attempted to visit these remote islands. An hour before daylight, on a wild winter's morning, we shoved off from the pier at Galway. The moon shone high in the heavens, but 18I 


\section{Wanderings of a Naturalist}

now and again her light was blotted out by a violent squall of hail, as great masses of dark clouds crossed the sky, driven by a fierce wind. Outside the harbour the sea was running mountains high, and though we made good progress against it, the waves were sweeping the small naval motor-launch, so that all on board were soon drenched to the skin. As we forced our way westwards the faint outlines of the islands showed themselves from time to time on the starboard bow, only to be enveloped in mist and rain with the coming of each fresh squall from the wide Atlantic. Once clear of the shelter afforded by Black Head we met the full force of the waves, and the sea increased to such an alarming extent that we were compelled to return to Galway, there to await more favourable conditions. A ventilator had been washed away unseen, and eight feet of water flooded the men's quarters, the launch's head being awash with the sea. Indeed, so low by the head was she, it was impossible to bring her round, and it was only by all hands standing over the propeller to give extra weight to the stern that the screw gripped the water at all. Thus precariously we went astern, great seas following us and rushing across our halfsubmerged bow. The pumps were choked, so it was impossible to get rid of the big mass of water on board, and it looked as though any minute the ship might founder. The fore-bulkhead held, however, and in the end we succeeded in making the comparative shelter of a bay about a dozen miles distant and there got the pumps going once more. Fortunately the wind shifted north towards sunset, and as next morning opened with a cloudless sky and only the gentlest of breezes, a second attempt to reach the island was made.

The waters of Galway Bay were of a deep blue in the strong sunlight, and ahead of us were a fleet of sailing trawlers busy at their fishing. Close to the boat there flew black guillemots, in their mottled winter plumage, and a pair of great northern divers were swimming near.

As we reached the open sea the range of hills, known as 182 


\section{The Aran Islands}

the Twelve Pins of Connemara, stood out clearly to the north, with just a sprinkling of snow on their summits; beyond them again, and nearly forty miles distant, I imagined I could make out the high hills which rise from about Killary-a district where it is said the golden eagle still lingers and where the raven still croaks among the rocky corries which guard Glen Erriff.

To the south the Clare coast stood out distinct, and one could see the high cliffs at Doolin Point against which the Atlantic surf beats continually and throws up the white salt spray even to the summit of the rocks. North-west lay the small group of reefs known as the Skird Rocks, many of them submerged at the full of the tide, and the group reminding one somewhat of the Torrans lying off the west coast of the Isle of Mull. On the Skird Rocks many grey seals have their haunt, and in summer those rocks which rise above high-water mark are tenanted by countless numbers of sea birds. I believe that the name Skird is a corruption of the Gaelic word Sgeir, meaning a rock, but throughout the west of Ireland, although the old language still persists, the present names appear now to be much further removed from the originals than in Scotland.

It was after midday when we approached our first callingplace-Innishear. A fresh breeze was now blowing from the north-west, but the sea was still blue and no heavy waves were running. As we heaved to, great activity was visible on a fine sandy beach on the north-west of the island, and we could see the light boats being run into the surf and pulled out rapidly towards us. These boats, or curraghs as they are called, are peculiar to the Aran Islands and the coast of Clare adjacent to them. In appearance they are canoe-like-long, deep and narrow, and with the bow raised high out of the water in order the better to ride over the heavy breakers. They are constructed of cowhide or canvas, yet are as strong and seaworthy as a much more substantially built craft. Most of these curraghs are four-oared, but each 


\section{Wanderings of a Naturalist}

man pulls two oars. A small sail can be set if necessary. It was in a curragh that the saintly Columba is said to have set sail from Ireland, and ultimately to have landed on Iona; indeed, on this latter island is a small bay, known to this day as Port a' churrach, where the curragh of the saint is said to lie buried.

One by one the curraghs reached us and came alongside, the men who rowed them primitive and wild-looking in appearance and talking excitedly to each other in the Gaelic. Many of them were in appearance curiously foreign, and indeed not a few of the island families are of Spanish descent -a relic of the days when the Spanish Armada came to grief along our western coasts. A well-known name on the Aran islands is Costello, surely of Spanish origin.

The islanders informed us that owing to a strike in Galway the mail steamer had not visited them for a fortnight, and that they were badly off for food and-what seemed to trouble them still more-tobacco. Indeed, I afterwards heard that it was only the emergency rations from the lighthouse that prevented a serious shortage of provisions on the island, for the weather had been so stormy that fishing was impossible.

From Innishear we set our course for the port of Kilronan on Innishmore, passing Innishmaan at a distance. On the west side of this island are precipitous rocks, and against these the long swell was thundering, throwing up great masses of spray that hung in the still air-for the wind had now died down-with fine effect.

On Innishmaan, as on all the Aran Islands, the kelp industry flourishes. In Scotland the crofters no longer cut the weed on the rocks, depending for their supplies on the tangles cast ashore by the winter's storms, but here the wrack is cut with sharp sickles from the rocks at low water, and made into coles after the manner of hay. In this form the weed may be left through the winter months, to be burnt with the coming of fine weather.

There is a legend on Innishmaan that over four-score 184 


\section{The Aran Islands}

years ago a quarrel arose from some trivial cause among a number of men who were cutting the wrack, and in the fight with knives that ensued no fewer than five persons were killed. It is said also that the people of Innishmaan, being the most primitive, were the last to become converted to Christianity from among the Aran Islanders. A certain saint in the end succeeded in half-converting them, and they commenced to build a church. Before the edifice was completed, however, the islanders began to doubt as to whether their conversion was sincere, so, holding a meeting, they decided to test the faith of the saint in the following manner : They agreed there and then to throw over the cliff into the ocean the tools with which the church was being built. For if, they argued, the saint was indeed endowed with miraculous powers, he would be able to recover the tools from the depths of the Atlantic. The tools were accordingly hurled over the rocks, but it is not recorded whether they were ever seen again. It is said, however, that the irate saint roundly cursed the islanders for their folly.

At Kilronan is an excellent pier, but the tide was low and so we dropped anchor in the bay and pulled ashore in the small boat. Lining the pier was a dense crowd of people awaiting our arrival. Many of the men were wearing broad tam-o'-shanters, which are, I believe, made on the island itself, and which used to be worn generally through all the islands. Some of the islanders were wearing a curious shoe of their own manufacture, which is known as a "pampooty." It consists of a piece of raw cowhide, with the hair on the outside, laced over the toe and round the heel with two ends of fishing line, which work round and are tied above the instep. When the pampooties are taken off at night they are soaked in a basin of water, for the rough hide is apt to cut the foot and stocking if allowed to harden. Wearing as they do such light and pliable footgear, the islanders have preserved the primitive and graceful walk which has been lost elsewhere with the coming of the unromantic boot. 


\section{Wanderings of a Naturalist}

On landing at Kilronan, and indeed surveying the islands as a whole, one is struck by the absence of any rich pasture land; the stones in their numbers more than rival the most barren parts of Ross-shire where the crofters struggle against adversity. Walls are few and far between, and with the coming of summer the grass becomes so parched that all the ponies are taken across to the Connemara hills to graze in the month of June, and are not brought back until the latter part of September, when the sun has lost most of his heat and the autumn rains have as a rule commenced.

Owing to this lack of moisture and the limestone nature of the soil there is no peat on any of the Aran Islands, and as the islanders burn little else it has to be transported from Connemara in smacks-a highly lucrative trade during the war and even after owing to the increased price of coal. If by any chance the supply of peat becomes exhausted the islanders fall back on dried cow-dung, which is said to make an efficient substitute.

On the Aran Islands frost and snow are almost unknown, and though on the mainland little growth was showing, on Kilronan, when I landed, jonquils and daffodils made the gardens bright. In conversation with one of the islanders, who in appearance and manner of speech closely resembled the Highlander of the west of Scotland, I learned that some years ago a certain small steamboat, well known throughout the west coast of Scotland and the Hebrides, and having her headquarters in Oban, was employed for a time on the run between Galway and the Aran Islands. Her Gaelic-speaking crew were able to converse with the islanders though with a certain difficulty, but there was one member of the crewan old man-my informant stated, whose Gaelic the islanders understood as though he was one of themselves, so that he became extremely popular, and was initiated into much local lore and taught the songs of the islands.

It was sunset as we weighed anchor and set our course for Galway. A few rose-coloured clouds lay above the 186 


\section{The Aran Islands}

summits of the high Connemara hills, but elsewhere the sky was clear, and with the wind light and holding from the north, there came a touch of frost to the air, which seemed to presage the long awaited spell of steady weather. Far along the coast of Clare one could see the salt spray from the Atlantic swell hanging motionless on the still air, and gradually the twilight fell and the lighthouses on the islands shone their beams far out to sea, while over all the moon-now near the full-shed her mellow light. 


\section{CHAPTER XL \\ SHORE BIRDS IN LATE DECEMBER}

A PENETRATING south wind brought to the bleak Northumbrian coast gloom and haze so that all view seawards was obscured. But a morning eventually breaks with-a most rare thing at this season of mid-winter -a dead calm prevailing and the air once more clear. Away to east lie the group of the Farne Islands, where during the season of their nesting countless thousands of seabirds make their home; and northward, Holy Island and its castle stand out against the horizon. Along the shore a very heavy surf breaks, and above the rollers hangs a mist of salt spray. Where the sands end and a reef of half-submerged rocks juts out into the sea bird life is plentiful. Quite close inshore a company of long-tailed ducks are diving energetically. The long-tailed duck during the winter months obtains almost all its food by assiduous diving, often to considerable depths. It feeds mainly on mussels and cockles, but periwinkles are also eaten. The birds are very regular in the duration of their dives, and on one occasion I timed one-a drake -which remained submerged for three consecutive dives a period of exactly thirty-seven seconds. I have also noticed that when a duck and drake are diving together the drake remains submerged rather longer than the duck. The long-tailed duck is found along our coasts as a winter visitor only. In late spring the flocks migrate north to their nesting-grounds in Iceland, Spitzbergen, the north of Norway and Lapland.

The strong flood tide carries the feeding duck rapidly past me, but their places are taken by others, for the "sea 188 


\section{Shore Birds in Late December}

pheasants"-a local name for the long-tailed duck-are numerous this morning, probably owing to the fact that the heavy swell is stirring up the shell-fish on which they feed. On one occasion a duck alights between two drakes, whereupon one of the latter stretches out his neck apparently calling, but his musical whistle is drowned in the roar of the surf.

Near them two red-throated divers in winter plumage are diving. They remain under water nearly twice as long as the long-tailed duck, but usually emerge with empty bill. Eventually one comes to the surface having captured a goodsized flounder. This fish, from its shape, proves an unwieldy billfull for its captor, which makes many unsuccessful attempts to swallow its prize. Periodically it shakes the fish vigorously, then dives with it, apparently finding it more easy to manipulate under water. In the end I leave the bird still struggling with its victim.

Some distance out to sea a great northern diver is swimming gracefully, at times lying over in the water to preen its breast sleepily. The largest of the diver tribe, the great northern diver is a wonderful swimmer and diver, and, although rarely taking wing, its flight is powerful and very rapid. It probably remains submerged longer than any other bird, and also dives to a greater depth. An instance is given by Howard Saunders of a great northern diver being caught in a net set at a depth of thirty fathoms- 180 feet, and a case is on record of this bird remaining submerged for a period of no less than ten minutes!

It is interesting to realize that the true divers-by which I mean the great northern, red-throated and black-throated species-can be distinguished even at a distance from the cormorant, which bird they somewhat resemble when swimming on the water, by their method of diving. The cormorant dives somewhat clumsily, springing into the air before submerging and leaving behind it a noticeable splash. The true divers, and especially the great northern species, on the other hand, disappear quietly and without fuss, leaving 


\section{Wanderings of a Naturalist}

scárcely a ripple to mark the spot. None of the divers has ever been known to nest in England. The red- and blàckthroated species nest sparingly in the Scottish Highlands, but the nearest breeding haunt of the great northern is Iceland.

Far out to sea great flocks of widgeon can be seen riding buoyantly on the swell, and near them are numbers of scoters - expert surf-divers, all of them. On the rocks are flocks of turnstones and purple sandpipers feeding at the edge of the tide. These small birds are wonderfully adept in following each succeeding wave, picking up minute living objects that it has left behind it and then running back at top speed before the onslaught of the next breaker. Often, however, the wave is too swift for them, and then the whole flock, as the rock on which they are feeding becomes rapidly awash, are compelled to take wing and seek fresh quarters. During flight the turnstones call with a pleasant twittering note, but $I$ have never heard the purple sandpipers utter any sound.

On a sandy creek a few oyster-catchers are feeding, and near them a flock of dunlin. The evolutions of this small wader when on the wing are nothing less than marvellous. Flying at express speed, the whole flock describe sudden twists and turns in perfect formation, at times even doubling back with seemingly never a pause in their flight. They appear to perform these evolutions for no other reason than the joy of life, and, when tired, alight on the sands and commence restlessly searching for food at the water's edge. Unlike the turnstones and purple sandpipers, which are essentially rock-frequenting birds, dunlin are almost always found on stretches of sand or mud-flats left bare by the tide.

The dunlin permit me to approach to within a few yards, then rise in a body, all except one bird, which remains behind. This individual appears as though he has suffered some injury to his wing, for I am able to approach within ten feet and he still makes no attempt at flight. He shows sense in that, on the coming of an extra big wave, he climbs up on to a 


\section{Shore Birds in Late December}

bunch of seaweed and remains dry until the wave has receded. When approached, he merely runs a few yards and then stands, half hidden, behind some patch of seaweed. But, to my surprise, after standing thus some time he seems to bestir himself, and uttering one shrill cry rises from the ground and flies very fast along the sand, being soon lost to view.

Close into the rocks a couple of cormorants and an eider duck are diving. At the coming of each wave the birds are forced to submerge to escape the wall of green water, but this seems to trouble them not at all. The eider soon comes up with some species of shellfish in her bill, but the fishing operations of the cormorants are unproductive. A little farther out a herring gull has fared better, for he has succeeded in capturing a gurnard. But to swallow this fish with its sharp fins and large head is a difficult problem, and it is after many unsuccessful attempts that the feat is accomplished.

The sun, these short days of late December, never mounts high above the horizon, and dusk falls early, but with many of the shore birds, night, as well as day, is a time for feeding, and whether they shall sleep or feed is determined entirely by the state of the tide. 


\section{CHAPTER XLI}

\section{CAIRN TOUL : AN ARCTIC CLIMB}

D

OWN in the glens rain, sleet, and soft snow had fallen continuously for many days, carried on a raw north-easter. The glass steadily crept backwards. Then, without warning, the air cleared one evening, and next morning broke with the ground in the grip of the frost, the air clear and still, and all the high hills free of mist almost to their summits. Even the lesser hills carried a thick covering of fresh snow, and their slopes were of an unbroken white, except where moving herds of deer showed up as black specks against the surrounding expanse of whiteness. In the big glen the larches were still golden, and some of the birches retained their brilliant autumn colouring. The river here was faintly peat coloured, and no breath of wind disturbed the calm of the deep placid pools. Over the little village of Inverey blue smoke hung, and from across the river came the strains of the pipes. In Glen Lui many stags were grazing, and hoodie crows flew restlessly, their harsh cries carrying far.

The ascent of Cairn Toul may be said to commence where the waters of the Derry and the Luibeag meet, for here the road is left behind and the track strikes west up Glen Luibeag, perhaps the most picturesque glen of the Cairngorm hills. Here, at a height of 1,500 feet and more, are splendid specimens of the native Scots fir, most of them veterans of over a hundred years and possessing a beauty and symmetry which firs in a plantation can never acquire. Many of these pine trees lie as they fell during a great storm of former years, their stems bleached by summer sun and winter storm. 


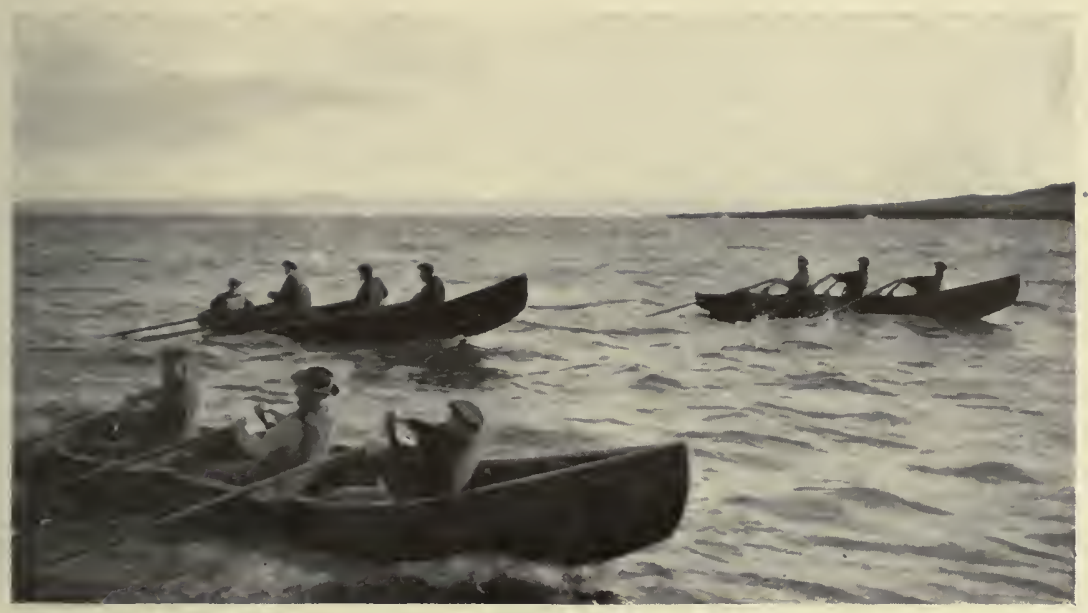

Aran Islanders rowing out in their Curraghs to a passing Admiralty Trawler.

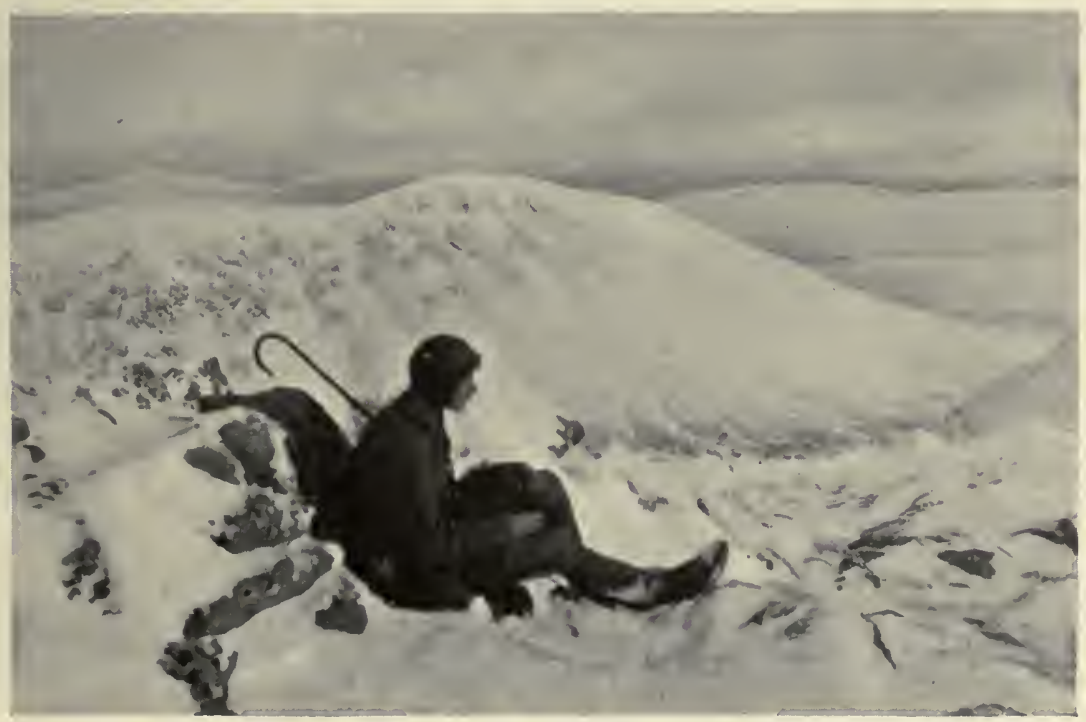

Looking across to Carn a' Mhaim from the Ridge of Cairn Toul. 


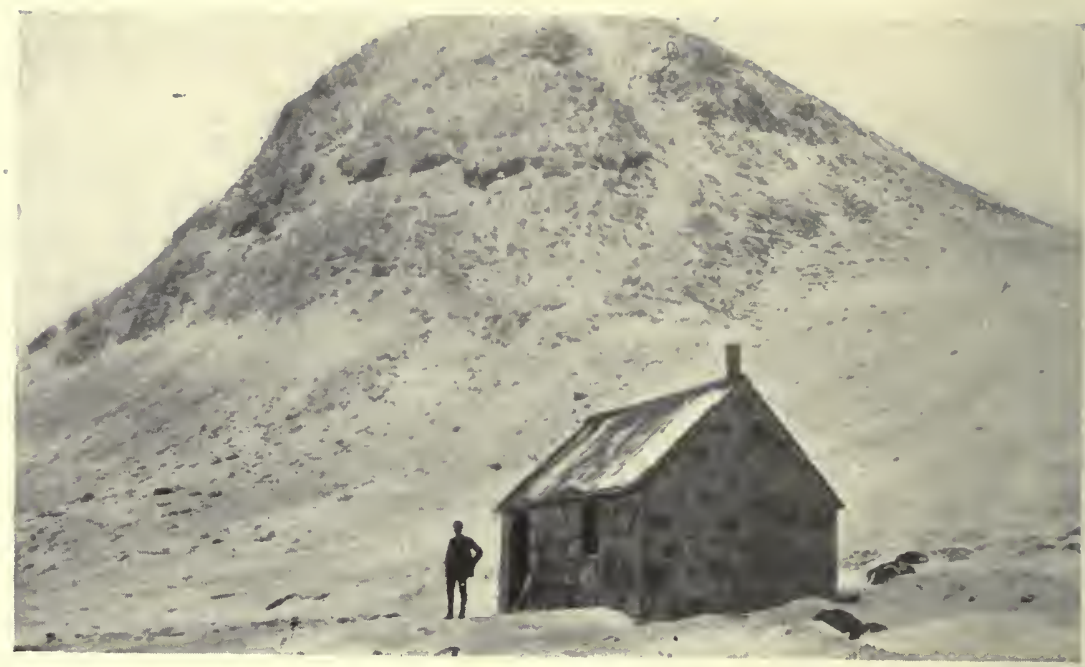

Cairn Toul: The Corrour Bothy and the Devil's Point.

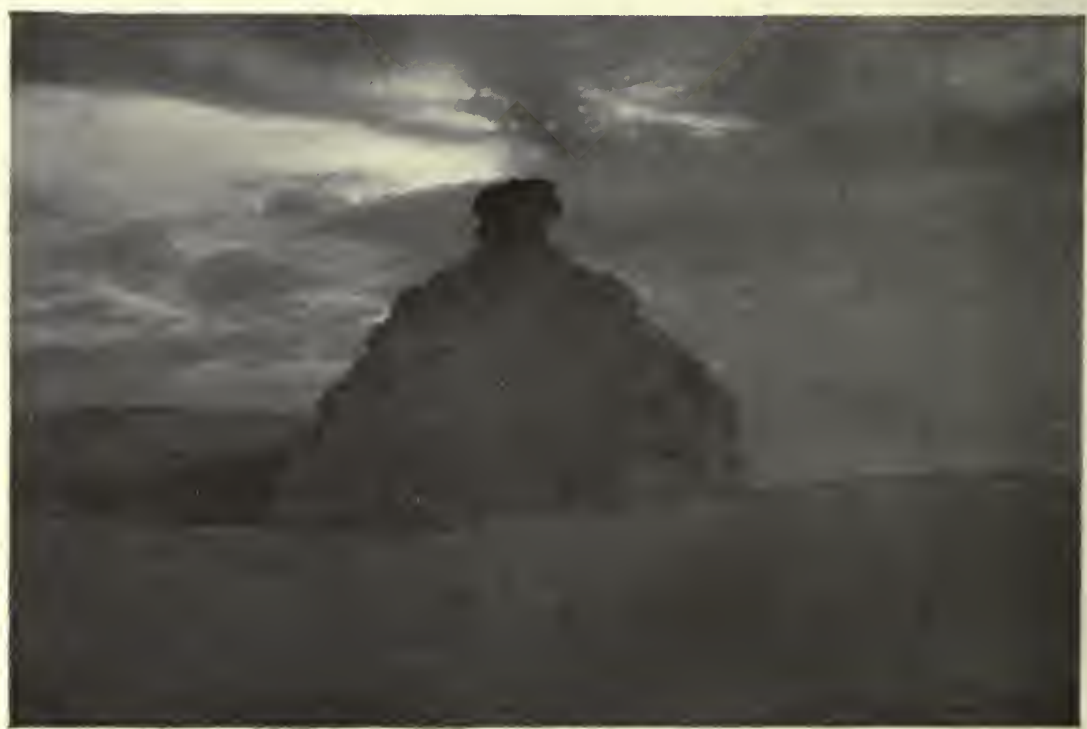

Cairn Toul: The Summit Cairn, ice-encrusted, at the approach of dusk. 


\section{Cairn Toul: An Arctic Climb}

The snow-line to-day was at about the 2,000-foot line. A few miles to the west Carn a' Mhaim reflected the clear sunlight from its snowy slopes, while in the distance Beinn Bhrotain and Monadh Mor stood out in unrelieved white. Perhaps two miles up the glen the track crosses the burn and rounds the shoulder of Carn a' Mhaim, and here extensive snowfields were met with. This snow had fallen towards the end of October, so now, a fortnight later, after successive frosts and thaws, gave a good walking surface. Grouse called loudly in the bright sunshine, and on the fresh powdering of snow that covered the old fall the track of more than one fox was visible.

Once beyond Carn a' Mhaim the track turns north and becomes the Lairig proper, which leads through the heart of the hills to Aviemore. From here one of the finest hillviews that Scotland can give meets the eye. Near at hand, and rising from just west of the Dee, the precipitous Devil's Point, towering to a height of three thousand three hundred feet, was flooded with sunlight, its rocks covered with snow and ice. Beyond it Cairn Toul was mist-capped, and away northwards an occasional glimpse was caught of Coire Bhrochain of Braeriach, with eddying mists hiding the summit of the hill. Beside the Pools of Dee, at the summit of the Lairig, the sun shone brightly and the ridge of Sron na Lairige was also sun-bathed. The River Dee was low this day, for the frost had imprisoned many of the smaller springs. Its hurrying waters, clear as crystal, were easily forded just where the lonely bothy of Corrour stands, as it were, sentinel over the Lairig. From here is a fine view of Ben MacDhui, for the summit of this great hill is not more than two miles distant. To-day the hill was buried beneath a very heavy fall of snow. At the top of Coire nan Taillear a great cornice hung, and the track of a small avalanche could be seen where, having broken from the cornice, the snow had rolled down into the corrie beneath. A thin mist half-veiled the top, but the cloud was so trans- 


\section{Wanderings of a Naturalist}

parent that beyond it the sun could be seen shining on the great expanse of unbroken snow.

From the bothy a stiff climb brings the hillman to Coire Odhar-a sheltered corrie much-frequented by ptarmigan in winter, and to the ridge above. A herd of some fifteen stags were feeding in the snow just to the north of Coire Odhar, and many footprints of ptarmigan crossed and re-crossed the frozen surface. These footprints led, as a rule, to some windswept patch, where one could see that the young shoots of ling, blaeberry, and crowberry had been nipped off by the white grouse. A little farther on a pair of these birds, in almost complete winter plumage, flew across the corrie, the cock croaking as he alighted, with tail upraised, on the snow at the farther side.

Small footprints in the snow showed where snow buntings had been feeding on the seeds of some of the taller hill grasses which appeared through the snowy covering, and near at hand were the tracks of a fox-cub and the smaller footprints of a stoat. The going was very stiff, for the snow was both deep and soft, with just sufficient of a crust to make each step tiring in the extreme, the surface of the snow half-bearing our weight and then "giving" at the critical moment.

The Coire Odhar burn was snow-covered almost throughout its length, and near the ridge at the top of the corrie was a sheet of nearly solid ice, the waters of the infant burn having insufficient warmth to flow through the icy expanse and being continually frozen to the ice sheet.

On Cairn Toul the mist gradually lifted, and at length the hill was clear to the summit, with the feeble winter sun shining on its cone-like apex.

The ridge at the source of the Coire Odhar burn is about 3,000 feet above sea-level, and from here to the summit of Cairn Toul is a gradual rise. We had hoped that on the highest grounds the snow would have borne us, but even here it was soft, so that each step was a struggle.

Following the ridge, and making very slow progress, 


\section{Cairn Toul: An Arctic Climb}

we at length came to the Buidhe Aonach of Cairn Toul-as the southern spur is named-where, at a height of just under 4,000 feet, the ridge dips a little until the gully known locally as the "slichit" at the top of Coire an t-Saighdeir is reached, and from here to the summit cairn is but a short ascent.

The "slichit" was half full of snow which, by its discoloured appearance, had probably been drifted in during the storms of late September and early October, when the wind was from the north-west (the more recent storms, coming from the north-east, would have drifted clear of the gorge), and, except with rope and ice axe, was to-day quite inaccessible.

The tracks of a fox led across the hill here, and the footprints of a ptarmigan were visible on the snow.

On each stone and rock fog crystals of most beautiful shape had been formed during the many days when the hill top had been mist-capped. These crystals, growing from the windward sides of the rocks, were fern-like in form, and on one stone in particular grew at every angle, radiating from a central spot where a solid circular lump of ice was plastered on to the stone-the whole bearing a remarkable resemblance to a catherine wheel in motion.

Mist was now low on Ben MacDhui, across the Lairig, and the sun was pale, with signs of a wide ring of rainbow colours encircling it-a pure portent of unsettled weather to follow.

A thin grey mist gradually enveloped us, but there was little or no wind, and consequently no immediate risk of drifting snow, so we pushed on up the last short ascent and soon saw, looming ghostly through the mist, the south cairn of Cairn Toul, thickly plastered with snow and ice.

And now, with wonderful effect, a rift appeared in the mist, and the sky was blue above us. In less time than it takes to relate, the cloud had lifted from the hill-top, revealing a landscape Polar in its grandeur in the steel-grey light of this winter afternoon. A hundred yards distant the north 


\section{Wanderings of a Naturalist}

cairn was so ice-encrusted as to be almost unrecognizable, while across the depths of the Garbh Choire the great hill of Braeriach stood out, free of mist to the summit. The whole of that hill was of unrelieved white, save where the infant Dee, fresh from its source at the Wells of Dee on the plateau of Braeriach, fell in cascades down the dark rocks of the corrie known as Fuar Garbh Choire, or the Cold Rough Corrie.

Curiously enough, although the west top-sometimes known as Einich Cairn - of Braeriach was clear, dense white clouds at a lower level hid Glen Einich and Sgoran Dubh.

Almost due north from the summit of Cairn Toul the unrelieved whiteness of the Lairig was broken by two small dark circles-the unfrozen Pools of Dee, set in a Polar expanse.

Beyond them the hill of Cairngorm appeared, with mist on its slopes, while across the valley of the Dee, Ben MacDhui was now clear to its summit.

Lochan Uaine, or the Green Lochan, nestling at a height of 3,000 feet in the north corrie of Cairn Toul, was so covered with ice and snow as to be almost unrecognizable, and away south of us that other high-lying loch-Loch an Stuirteagbeside the north slopes of Monadh Mor, was in like case.

The head waters of the Geusachan, where that burn has its source just west of Cairn Toul, were entirely hidden beneath the snow, so that it was difficult to believe a fair-sized burn flowed imprisoned through the snow-clad corrie.

To-day there was no distant view, except southward, where Beinn a' Ghlo and the hills about Glen Shee and the Cairnwall stood out clearly. North and west, clouds of grey white vapour hung low on the hills, seeming to presage a fall of snow, and these clouds near the sun were transformed by warm rosy tints.

On the summit of Cairn Toul an average depth of about three feet of snow covered the ground, and the thermometer 196 


\section{Cairn Toul: An Arctic Climb}

stood at 20 degrees Fahrenheit, or twelve degrees of frostthe time being just three o'clock in the afternoon.

Not a breath of air stirred-no roaring of stags in the corries beneath nor ptarmigan's croak disturbed the great silence of the high tops fast in the grip of winter.

Gradually the light faded, but the moon was at the full, and we knew there could be no darkness to-night.

In the grey light a covey of ptarmigan flew swiftly past us, hurrying south. Closely following them there sped a darker bird-perhaps a peregrine-in hot pursuit, but in the twilight it was difficult to see clearly.

We had not long left the summit when gradually thin grey mists spread over the hills, but away eastwards the setting sun shone on the level top of Beinn a' Bhuird $(3,900$ feet) though the glen beside the hill was filled with cloud.

The dark pines in Glen Quoich-where pines grow at a greater altitude than anywhere else in Scotland-relieved the expanse of snow in that glen, until they, too, were hidden in the advancing mists.

The full moon was rising behind Carn a' Mhaim ere we descended to the Lairig once more. Westward, the remnants of the sunset still lingered in the sky, lighting up the clouds on the horizon a dull red hue.

From Cairn Toul, from Braeriach, from Ben MacDhui, the mists had once more lifted, save where they slipped, ghost-like and in silence, down the ridge of Ben MacDhui and into that fine corrie known as Coire Mhor na Lairige.

On the shoulder of Cairn Toul the moon shone brilliantly, lighting up the snows as though with diffused sunlight, the hill-top itself, though wonderfully clear, being in shadow.

On the dark pools of the River Dee a thin layer of black ice was stealthily creeping out over the waters-for even in the Lairig the frost was intense.

From the slopes of Carn a' Mhaim, clear in the moon- 


\section{Wanderings of a Naturalist}

light, came the hoarse challenge of a stag, and so light was it, grouse still crowed from the heather beside the track.

But late that evening hurrying clouds from the east obscured the moon, and the deer hastened to the low grounds, even entering the village of Braemar towards midnight.

Snow, soft and powdery, commenced to fall before that hour, and by morning a good ten inches covered even the glens. Throughout the day the fall persisted, and with its ceasing a fierce frost bound all the countryside, so that, with the thermometer showing 40 degrees of frost, the Dee was soon frozen across from bank to bank, for full winter, before her time, had come to the hills and the glens. 


\section{CHAPTER XLII}

\section{THE LONGSTONE RELIEF}

A GREY December morning. All through the night a gale from the south-east has been blowing, with thick driving rain, but an hour or so before daybreak the wind shifted to south-west, and now the sea is moderating under the influence of the land breeze.

A three-mile walk along the exposed Northumberland coast brings the writer to the little village of Seahouses, from where an attempt is to be made to carry out the relief at the Longstone Lighthouse-a lonely light built on the most outlying of the Farne Islands. A heavy surf, the result of the night's gale, thunders on the long smooth sands which lie between Bamburgh Castle-that restored ruin where the Kings of Northumbria had their home-and Seahouses, and on the Inner Farnes the swell can be seen breaking heavily.

It is just ten o'clock when the powerfully-built motorboat swings out through the narrow entrance to the harbour and heads for the Longstone, between four and five miles distant, and bearing about east-north-east.

On board are the mails for the rock station, and a certain quantity of provisions. We also carry the lighthouse-keeper, who, his shore leave completed, is returning to the Longstone, where he will spend his Christmas.

Just clear of the breakers a company of eiders, ducks and drakes together, are diving energetically for food, and near to us a cormorant emerges with a good-sized eel held firmly in his bill. Instantly a watching herring gull flies at top. speed towards him, but the cormorant dives quickly, carrying down his prize with him, and the gull circles round, baffled. Soon, up again comes the cormorant, and again the 


\section{Wanderings of a Naturalist}

gull rushes at him with evil intent. The cormorant now makes desperate efforts to swallow his catch, and this he does successfully before the gull can reach him. His voracious appetite still unsatisfied, he dives af resh to search for further victims.

Once clear of the harbour entrance, we begin to feel the long swell coming in from the south-east, but running as we are before the wind, the air is almost calm. Ahead of us the fishing boats from Seahouses are lying at their long lines, the heavy swell from time to time entirely hiding the craft from view. A Scottish steam drifter, bound for her home port in the Moray Firth, her fishing at Yarmouth ended, passes north between the Inner Farnes and the mainland, her mainsail set to catch the breeze, and grey smoke trailing from her funnel. Never-so it is said on the Northumbrian coast-have so many Scottish herring boats passed by, all steaming north, as during the fortnight before this day of which I write, and their number must have well exceeded a thousand.

Bird life is plentiful. A flock of godwits fly swiftly by, seeming like miniature curlew, except that as they pass it can be seen that their bills lack the downward curve of the latter bird, and that their flight is more swerving. Scoters hurry singly and in bunches over the surface of the sea, or settle in flocks on the water, and a red-throated diver in winter plumage wings its way past us, making for some favourite fishing ground.

Our course takes us about half a mile to the south'ard of the island known as Inner Farne, with lighthouse, automatic in its working, perched on the top of a rock on which the surf is now breaking in white cascades of spray. Passing the Brownsman, we see several young grey seals lying on the rocks, one of their number, from its cream-coloured coat, being apparently of a very tender age. Almost joined to the south end of the Brownsman are three flat-topped rocksthe well-known Pinnacles. Here in summer thousands of 200 


\section{The Longstone Reiref}

guillemots resort to lay their eggs, and even now, in midwinter, the breeding place of these birds is still white with guano.

After a crossing of forty minutes the motor-boat is run into a sheltered landing-place just beneath the Longstone Lighthouse, and the light-keepers hasten down to the slip to meet us.

The Longstone is uncovered even at the highest spring tides except during very wild weather, but nevertheless no vegetation of any kind grows on it. During summer a few eider duck and arctic terns nest here, and occasionally a grey seal may drop her youngster on the rock during the breeding season in November. I am informed that the grey seals are frequently heard around the Longstone; they call most just before foggy weather, and their cry is a mournful one, resembling the howling of a dog.

As we land at the slip a solan is circling round the outlying rocks on the look out for fish. It is a bird of the year, and of a uniform dark colour. In all probability it has been bred on the Bass, and is now on its way south, for the gannet is uncommon off the Northumbrian coast in December. Bird life is plentiful this morning on the Longstone. A heron stands sedately at its fishing pool, while a pair of oyster catchers watch our arrival with interest. Redshank call fussily as they take wing, and flocks of turnstones and purple sandpipers-feeding in company, as is often the case-busy themselves in picking up the edible morsels from the tideswept rocks. Very tame are some of these birds, allowing us to approach without any show of alarm. Near them, a rock pipit searches actively for insects.

During a rapid inspection of the lighthouse I am shown the room in which Grace Darling, of immortal memory, was in the habit of sleeping.

In clear weather an extensive view may be had from the Longstone. To the west, Cheviot stands against the horizon, dark blue of a summer's evening, sparkling white of a 


\section{Wanderings of a Naturalist}

December morning. In very clear weather the reflection from the light on May Island, at the entrance to the Firth of Forth, can be made out, but bad weather usually follows this exceptional visibility. Only a couple of days previous to the relief the Aquitania (46,000 tons) was seen passing south, quite close in, on her way to the Tyne for a refit. She is probably the largest vessel ever seen off the Northumbrian coast.

Our stay at the rock is a short one, for the sky betokens rough, dirty weather to come. Round the sun is a wide rainbow ring, and away to the north the sky is a stormy green, with the Cheviots quite blotted out in the thick haze.

From various directions the fishing cobles, their lines hauled in, are making for the shelter of Seahouses harbour, and it looks as though before night another gale will be raging.

The engine set a-going, we shove off, having as passenger the principal lighthouse-keeper, due for his fortnight on shore. Our course on the return journey is a more southerly one, in order to allow for the drift of the ebb tide, and we pass closer to that long and low rock known as the Crumstone, where is the chief breeding ground of the grey seal on the Farnes. Rare indeed is the day when the sea is sufficiently calm to permit of a landing on this rock, for a swell almost always breaks about it, and there is no landing-place with any shelter. During fine, sunny days in November and December grey seals, both young and old, may be seen basking on the Crumstone, sharing the rock with gulls and cormorants.

As we pass the Crumstone the haze lifts somewhat, and Bamburgh Castle can be seen standing, stern and grim, away to the west. Farther north Lindisfarne Castle, on Holy Island, can be made out, but all beyond is indistinct. Away on the southern horizon the mainsail of a herring drifter just rises above the water, but quickly becomes more distinct as the boat, on her northerly course, approaches us. Outside the islands a destroyer is steering for the Scottish coast. 


\section{The Longstone Relief}

Ahead of us a number of long-tailed ducks are swimming and feeding, and we have an opportunity of watching them for a while. The company consists of seven birds-five ducks and two drakes. The latter seem to ride more buoyantly on the water, and their very long tail feathers are held jauntily in the air, whereas in the case of the ducks these long tail feathers are absent. Every now and again one of the drakes pursues his rival across the water, and then both birds fly round for awhile, with tail feathers drooping, before alighting on the water and sliding for some yards along the surface before coming to rest. Periodically all the seven birds dive, opening their tails, razor-bill fashion, as they submerge. They seldom remain below water more than thirty seconds. The sun, now shining fitfully, lights up the handsome plumage of the drakes and shows the white breast and brown cheeks distinctly.

The harbour of Seahouses is reached with the first of the fishing fleet, and the wind still remains light, though every sign of the sky appears to signal an approaching storm. 


\section{CHAPTER XLIII}

\section{A FEBRUARY DAY ON THE DEE}

THE frost of the past few days has "louped," as they say, in the night, and the morning air is soft and mild. Along the valley of the Dee there.is much activity, for the river is opening its waters after the close season of winter. Yet it is difficult to realize that winter, or the greater part of it at all events, has gone, for there has been an almost entire absence of snow, and little frost. This morning, were it not for that unmistakable odour of spring given off by the humid earth, it would be easy to imagine the season as October-and a mild October day at that.

A narrow track, leading from the high road through a plantation of pines, brings one to the river bank. The water is low-too low for a successful opening-and clear; for the month of January in Aberdeenshire this season was a dry one, and there is little or no snow on the hills to keep up the river. The line is wetted, and, with that added interest of the unknown which must always mark the first day of each season, the first pool is fished carefully down, the fly a sober-coloured "Glentana." At the head of the pool a couple of red-breasted mergansers are energetically fishing, and three or four mallard rise from the water's edge, quacking huskily. No oyster catchers as yet people the long pebbly shingles-it is not until the opening days of March that they arrive at their nesting grounds-and no sandpiper flies twittering just above the river's surface. But water ouzels fly and dive, and a sparrow hawk passes by at its hunting.

The first pool is fished down-not a fin showing. The 204 


\section{A February Day on the Dee}

second gives no better results, and one's early enthusiasm begins to wane. But the best pool of the water is close at hand, and here at least, says the ghillie, there are fresh-run salmon in plenty, and success is sure to follow. A long deep pool, this, spanned by a bridge near its middle; a strong current near the top of the pool, gradually slackening till, near the tail, in this low water, the river's motion is scarce perceptible. This pool is fished from a boat, and on rowing up to the head of the stream we pass, resting moribund near the water's edge, a diseased salmon with fungus growing thick upon it. On the far side of the stream a fisherman on the opposite bank has landed a small silvery spring salmon, and up and down the pool fish break the surface of the water.

A few casts, then a tightening of the line-a false alarm, a small ice floe fouled the line in its passing. The temperature of the water this morning is only 33 degrees Fahrenheit -one degree above freezing point-and only a slight frost is needed to fill the river with floating ice or "grue." After a disheartening spell of unprofitable casting over waters apparently in perfect order a salmon at last rises to the fly -a white-winged Ackroyd-but he comes short, and in the slack water, with a strong wind "sagging" the line into the bargain, the hook is not driven home.

From this point onwards the pool seems full of fish. From the boat one can see them plainly in the clear depths, large 20-pounders and small spring fish of from 6 to 8 pounds. But the water is too clear. Not a rise, save indeed where a fish, excited by the fly, leaps near it clear out of the water, rewards the most careful and assiduous casting. The fly is changed no fewer than four times without result. The wind rapidly increases. In the pine wood above, the trees toss and sway, and the deep sighing of the wind is borne across to us on the river. Casting becomes difficult, for the wind blows now this way, now that, and the boat becomes hard to manage. To make matters worse the early after- 


\section{Wanderings of a Naturalist}

noon sun breaks through the quickly moving clouds and shines brightly down on the river.

This fine pool is given up for the day, for its fish are obviously not on the take, and a small pool just above is casted over. Almost at once a heavy fish takes the fly. Its appearance is doubtful, but one hopes for the best, and the fish, getting well away with the current, rushes clear out of the pool and down two hundred yards of heavy water before being brought to the shore. It is not until it has been tailed that the worst is confirmed-a heavy $20 \mathrm{lb}$. "kelt," or spawned female salmon, and so to be returned to its element; the angler by this time almost as exhausted as the fish itself.

The short February day is drawing to a close. The sinking sun is obscured by hurrying clouds, sweeping across from the north, and gradually the hills are enveloped in mist.

About four o'clock the last pool, broad and placid, is reached. On it is swimming a tufted duck, not a common bird by any means on the Dee-but not a sign of a fish. Half-way down the pool a faint touch-these early February salmon rarely rush at the fly like the late spring fish-and one is into a small and lively fish. Surely a clean salmon this time. Its strength is rapidly spent-a bad sign-and the fish turns out to be another kelt. This is the uncertainty of early fishing; one can never be sure whether the fish hooked is clean-run or not, and, as a general rule, the kelts exceed the clean fish at this season by three to one.

At the tail of the pool another salmon takes the fly, but he comes short, and in the gathering dusk one prepares to leave the river bank.

But with the last cast of the day a salmon, flashing across the pool, seizes the fly. They are both active and powerful, these small February fish, and it is not without a struggle that he is brought to the shore-a perfectly clean-run fish of $8 \mathrm{lbs}$. 


\section{CHAPTER XLIV}

\section{LINDISFARNE IN FEBRUARY}

$\mathbf{A}^{\mathrm{p}}$

FULL gale of westerly wind sweeps the coast. From the Cheviots, hazy and mist-capped in the distance, thin grey clouds race at great speed away out over the North Sea. At times the sun breaks through the cloud canopy and floods the countryside with his rays, now visibly strengthening with each day. On the eastern horizon stands the grey island of Lindisfarne, or Holy Island, where, during the months of winter and early spring, a multitude of shore birds make their home. Holy Island is an island only for a couple of hours or so of each spring tide. At other times one can walk across the three miles of sand with feet comparatively dry. Two rows of posts mark the track, for on either side are quicksands ready to engulf the unsuspecting pedestrian. To-day a trap meets me near Beal Station, and the driver informs me that there is just time to get across before the flood tide sweeps in. The westerly gale is banking up the Atlantic off the North of. Scotland, and here, on the North Sea, the result is shown in an exceptionally strong flood tide, racing down from the north. Before we can reach the sands, Holy Island is cut off from us by a swiftly flowing and rapidly deepening strip of turbulent waters several hundred yards in width. However, the driver feels he can make the passage, so we move slowly forward through several feet of water. A curious feeling this, to be making one's way in a trap through a waste of waters. The old horse whinnies doubtfully, but brings us across to the dry sands on the further side of the channel without incident.

The incoming tide is driving in the birds from their 207 


\section{Wanderings of a Naturalist}

feeding grounds. A big flock of dunlin wheel past, the sunlight turning their plumage to flashing silver. Mallard fly westward, making for ponds of fresh water inland.

Not far from us a company of perhaps sixty brent geese are swimming. They arrive in these waters in November, and rarely remain after the middle or end of February. These dates are interesting as compared with the arrivals and departures of the brents at their great winter haunt at Malahide, near Dublin, where I have frequently studied them. Although the latitude of Malahide is considerably south of Lindisfarne, and the climate much milder, the brent geese reach their winter quarters here in late September, and do not leave them till the very end of April. The nesting grounds of the brent geese are in the Arctic-very far north. Indeed, even now, little is known of their breeding habits. They apparently nest on the island of Kolguev, for Mr. Trevor-Battye, in his book, "Icebound on Kolguev," tells us how the natives slaughter thousands of these birds during the moulting season, when they are quite unable to fly. As showing the wing power of these geese, and their rapid migration south in autumn, an instance is on record of certain molluscs, known to occur only in the Sea of Okhotsk, being discovered in the stomach of a brent goose shot on the Yorkshire coast.

The brent is perhaps the most truly marine of all our geese. They never in any circumstances go beyond the tide marks, feeding on the sea grass, known as Zostera marina, which is found growing on most estuaries and mudflats. Toward dark all these geese rise in a single body, consisting, perhaps, of several thousand birds, and, with much hoarse calling, make their way out to sea, where they spend the night. Curiously enough, the exact opposite is the case with the widgeon. These duck, although their feeding grounds, and even their feeding, are similar to those of the brents, fly out to sea at daybreak, as described in a previous chapter, and, having spent the daylight perhaps half a mile 208 


\section{Lindisfarne in February}

from the shore, move in to their feeding grounds at dusk. Under ordinary conditions the duck feed in more or less the same place throughout the night, but old wild-fowlers will tell you that for three nights in each month-namely, the nights preceding and following and the night of the full moon-the widgeon fly backward and forward in the bright moonlight as they change their feeding grounds.

The tide is near the full as we reach Holy Island. At the edge of the waters ringed plovers are endeavouring to find some shelter from the gale, and grey crows haunt the shore restlessly, uttering harsh cries.

From the surface of the sea the gale is snatching the waters in spindrift, on which the sun's rays form the colours of the rainbow. The tide is at the full, and so high that the Longstone Rock is almost entirely submerged, and the lighthouse appears as though rising from the waters themselves. I hear how, a few days previously, two fishing cobles from Seahouses were caught, while fishing off the Farnes, in a violent gale from the south-east. For long they attempted to tack home in the teeth of the gale, but ultimately were obliged to run for shelter at Holy Island, where they reached the harbour not without considerable difficulty. On the battlements of the castle the gale blows with such force that it is difficult to stand, and so strong is the land wind that no swell breaks on the shore, not even the tiniest wavelet. Close inshore a tramp steamer makes her way north. Looking in that direction one can make out the haze hanging over the town of Berwick-on-Tweed, and, farther north, the clearcut line of St. Abb's Head.

Making my way round the coastline of the island, I can see many birds swimming close inshore as they shelter from the gale. Numbers of jet black scoter drakes, with beautiful glossy hue on their plumage, ride buoyantly together. A few of their numbers, swimming rather by themselves, can be identified, by reason of the white bar on either wing, as velvet scoters. It is stated that the velvet scoter usually 


\section{Wanderings of a Naturalist}

remains farther out to sea than the common scoter. It is considerably scarcer than the latter bird, but is found distributed up and down our coasts during the winter months. Not far from the scoters-which are diving assiduously-a few scaup are swimming, while four long-tailed ducks, or sea pheasants, as they are locally known, are also busy at their feeding. Two of them are drakes, with long tail feathers blown this way and that, and their excitement when the ducks, after diving, emerge beside them seems to point to the fact that the recent spell of mild weather has caused the birds to pair early. Despite the gale which threatens to blow them bodily into the sea, turnstones are actively engaged in turning over with their heads the half-dried weed; at times almost disappearing in the hollows which they have made, and where they eagerly pick up the small crustaceans they have exposed. As far as my experience goes, purple sandpipers, which are found at times with the turnstones, never turn over the seaweed in this manner in their search for food.

A little farther on is a large flock of that very interesting wader, the knot. The sun, shining full on their lightcoloured winter plumage, makes them appear almost as white as the surrounding seagulls, and when they rise in a compact body to fly off to another feeding ground near by, the sunlight from time to time transforms them as they wheel and manœuvre gracefully together. Now they travel at swiftest speed just above the ground, now they rise abruptly high into the air and hang, pendulous against the wind. Althougl as a winter visitor the knot occurs in suitable localities throughout our coasts, even at the present day little is known as to where its main breeding haunts are situated. The only thing certain is that they lie far within the Arctic Circle-as far as vegetation penetrates. The birds are said to nest occasionally in Iceland, but the first clutch of fully authenticated eggs was obtained from the Taimyr Peninsula in I90I.

A well-known naturalist, who was fortunate enough to 2 IO 


\section{Lindisfarne in February}

study the knot at its breeding grounds in North-east Greenland, gives an interesting picture of its home life and courtship. According to this authority the love-song of the knot is an extraordinarily fine performance. The singer mounts almost perpendicularly into the sky, uttering the while his curlew-like whistle, until he has reached such a height as to be invisible to the eye and can be located by his song alone. Descending abruptly he comes to rest on the still snow-clad ground, with wings held stiffly above his head. Nesting in such northerly latitudes, the knot does not lay until the early days of July, or as soon as ever the snowy covering has left the ground. In the British Isles knot in full breeding plumage may be seen passing northwards until well into June, and as the earliest returning migrants from the north reach our coasts by the end of July the birds are scarcely ever absent from our shores.

I am informed that several fulmar petrels were sailing over Lindisfarne Castle in autumn, and ultimately disappeared in a westerly direction, while during the winter a specimen of that rare, accidental visitor, the little gull, was shot. This bird is essentially continental in its breeding, and so its visits to these islands usually occur after easterly gales.

It is four o'clock when the return drive is commenced. The tide is half-ebb and much of the sands are now exposed. The wind has backed south-west and moderated considerably. Wandering across the bleak flats one can see solitary fowlers making their way to the water's edge, where they will await the evening flighting of the widgeon. Dusk is falling as we commence to cross the sands. Curlew are feeding in the ooze, and, as we pass, rise into the evening air with much mournful wailing. Across the sky there still hurry stormdriven clouds, through which the moon struggles to throw her subdued light on wind-swept sands and shimmering sea. 



\section{INDEX}

ABERdEenshire, heather 1n, 140,142 Accentor, hedge, 134

Achill Island, Croaghaun of, $172-76$ Allt Choire Dhondail, 81 Allt na Beinne-Moire, 55 All na Garbh Choire, 82 Allt nan Taillear, 160 Alps, Maritime, blaeberry on, 157 Aquitania, the, 201 Aran Islands, 181-87 Arctostaphylos uva-ursi (see Bearberry) Ardnamurchan, 86, 89, 92, 100 Ardnamurchan Lighthouse, 86, 92 Argyll, Earl of, and Mull, 6r Argyllshire, coast of, $5^{8} \mathrm{et} \mathrm{seq}$. Arinagour, 87 Arnamul (Mingulay), 103 Ash, mountain, $\mathbf{5}^{1}$ Avern (avron), 156 Aviemore, 55, 84, 149, 193 Azalea, creeping (azalea procumbens), $52,55,56,80,159.78$

BaC Beag, 45

Bac Mor (The Great Mound), 45, 61, 89 Ballemartine, 46

Balmoral Forest, III

Bamburgh, II

Castle, 20, 23, 199, 202

Bamburgh Point Lighthouse, 23

Barra, Hecla of, 87

Island, $87,88,89,92,96$, roo

Sound of, $90,92, .93$

Barra Head Lighthouse, 47, 92

Bass Rock, migrants on, 134 solan geese and, 22, 130 et seq.

Beacons, the, 22

Bearberry, I55, I56, 172

Beinn a' Bhuird, 57, $146,148,197$

Beinn a' Charnain, 79

$$
\text { O* }
$$

Beinn a' Ghlo, 57, 1 38,1 59, 196

Beinn Avon, 57, 146

Beinn Bhearnach, 92

Beinn Bhrotain, 65, $121,135,152,167$, 193

Beinn Buie, 59

Beinn Chreagach, 44

Beinn Eolosary, 44, 45, 46, 47

Beinn Fada, 92

Beinn Hough, 45

Beinn Hynish, 45

Beinn Mheadhon, 53, $15^{8}$

Beinn Talaidh, 92

Ben Alder, 64, 67

Ben Cruachan, 39, 172

Ben Eibhinn, 64

Ben Lawers, 39, 64, 67

Ben MacDhui, 38, 39, 52, 54, 56, 65, $67,77,135,136,149,158.163$, $180-93,195,197$

Ben Mor Assynt, 138

Ben Mor (Mull), 47, 58, 88, 92, 96

Ben Mor (South Uist), 47, 9r

Ben More, 39

Bennaidh, the, $37,150,163$

Ben Nevis, 39, 47, 57, 59, 64, 67, 81, III

Ben Wyvis, $13^{8}$

Berwick-on-Tweed, 24, 209

"Big and Little Dutchman," 45

Bilberry, 156

Biulacraig, ror

Blackcock, battle call of, 32

Black Head, r 88

Black Rock Lighthouse, 173

Blacksod Point, I74

Blaeberry (whortleberry); 30, 37, 30, $64,1_{37}, 150,1_{54}, 155,157,159$, 194

Bog myrtle, 42, 91 


\section{Index}

Borreraig, piping school at, 62

Borreray, Island of, 91

Boxwood, 10

Braemar, 198

Braeriach, 37, 64, 66, 67, 77, 81, 82, $83,136,139,152,160,163,167$, $177,179,180,197$

summit cairn of, 84

"British Bird Book" and storm petrel, 73

Brownsman, the, 25, 200

"Bru, The," 45

Budle, estuary of, 21

Buidhe Aonach, 159, 1.95

Bunavon Eader, 77

Bunting, corn, 93

reed, 42

snow, 32, 134, 194; plumage of, 7 , 65

Bustard, little, 22

Buxus sempervirens, 10

Buzzard, 44, 45, 78, 114,118

Cairngorm, 51, 52, 56, 57,65, 137,238 , $149,158,160,196$

Cairngorm-Ben MecDhui, 84

Cairngorm Hills, 51, 77, $121,136,138$, $150,156,158,160,161,163,167$, 177,192

range limit of heather on, $14^{I}$

snow-line on, 81, 193

Cairngorm of Derry, 135, 158

Cairngorm stones, 161,162

Cairn Toul, 39, 54, 56, 63, 65, 67, 77, $83,136,137,159,160,161,167$,

Cairnwall, 196 $177,180,192$ et seq.

Calluna vulgaris, 91, 140, 141, 142, 151

Canna, 47, 91

Capercaillie, 55

Carex, 178

Carn a' burg beag, $6 x, 62$

Carn a' Burg Island, 45, 89

Carn a' Burg mor, 6r

Carn 2 ${ }^{3}$ Mhaim, 121, ז35, 159, 1.93, 197

Carsaig, $5^{8}$

Castlebay, 47, 87, 88, 92

Ceann a' Bharra, 45
Chamois ("izard "), 9

Cheviots, 11, 23, 25, 26, 29, 170, 201, 202, 207

Chough, 176

Alpine, 7

Clais an $\mathbf{t}^{3}$ Sabhaill, 63, 66

Clais Luineag, 63,64

Clare Island, 175

lighthouse on, 176

Clarke, Mr. Eagle, on storm petrel, 73

Clisham (Harris), 77 et seq.

Cloudberry, 156

Coire an Lochan, $51,57,85,163$

Coire an t-Saighdeir, 195

Coire an t-sneachda, 51

Coire Bennaidh, 85

Coire Bhrochain (Corrie of the Por ridge), $160,177,179,193$ legend of, 84

Coire Chais, 51

Coire Chreagach, 160

Coire Dhondail, 37, 63, 81

Coire Dhubh, 79

Coire Ghorm, 47

Coire Mheadhon, $6_{4}$

Coire mhor na Lairige, 57, 197

Coire na Cailliche, 64

Coire nan Each, 64

Coire nan Taillear, 136, 193

Coire Odhar, 37, 64, 150, 194

Coire Ruadh (Red Corrie), 85, 177

Coll, Island of, $47,6 r, 86,87,92$ piper of, 62

Cormorant, 17, 21, 24, 25, 176, 189, 191, 199

Corrour Bothy, 135, 193

Cowberry (cranberry), 30, 135, 154

Craig Leith, peregrine on, 134

Cranberry, $135,155,156$

Creag na Leacainn, 52, 55

Crianlarich, 39

Croagh Patrick, 175

Croaghaun, the (Cruachan), $172-76$

Crow, carrion, aI grey, 30, 93, 114, 209 hoodie, 192

Crowberry, 154, 156, 159, 194

Crumstone, the, 25, 202 


\section{Index}

Cuchulain Hills (Skye), 39, 47, 58, 80, $9^{1}$

Cunach, 166

Curlew, 1, 12, 32, 34, 36, 46, 51, x70, 211

Curragh, 183

Cushion pink (silene acaulis), 38, 52, $55,8 \mathrm{I}, 109$

\section{Dabeocia polifolia, 142}

Dalnaspidal, 166

Darling, Grace, room of, at Longstone, 201

Dee, River, 54, 66, 67, 81, 135, 177, $178,179,193,197,198,204-6$

Linn of, salmon and, 120 et seq. pools of, $54,137,162,193,196$ salmon spawning in, 146 et seq. source of, 82, 196 valley of, $65,146,159,180$ wells of, 38, 81 et seq., 196

Deer forest, life of, 30 et seq.

Devil's Point, 135, 137, 159, 193

Diver, black-throated, 189 great northern, I71, 182, 189 red-throated, 189,200

Dooagh, 172

Doolin Point, 183

Dotterel, 31, 53, 178 nesting site of, ro5 et seq. plumage of, 106

Duart, Castle of, 59, 86 Laird of, 59

Dubh Hirteach Lighthouse, 46, 60, 7I

Dubh Loch, 57, 146

Duck, eider, 24, 191, 199, 201 long-tailed, 188, 205, 210 mallard, 204, 208 tufted, 40, 41, 206

Dun EEngus, the, $18 \mathrm{r}$

Dùn dà Ghaoith (Hill of the Two Winds), 59, 92

Dun $1,46,92$

Dun, the (Doune), 165,166

Dunlin, 14, 15, 20, 21, 22, 171, 190, 208

Dunoon, $5^{8}$

Dunvegan, 91

Dutchman's Cap, the, 61,89
EAGLE, 30, 53, 63, 78, 85, i51, 165,167 , $178,179,180$

booted, 9

golden, 64, 137, 138, 152, 162, 168, 173; nesting site of, $3^{1}$

sea, 100,173

Eagle Island Lighthouse, 174 .

Easaval of South Uist, 90 et seq.

Eaval (North Uist), 47

Eigg, 47, 58, 91 Sgurr of, 88

Einich Cairn, 82, 196

Empetrum nigrum (see Crowberry)

Erica cinerea, 91, 140, 141, 142

Erica Mediterranea, 142

Erica tetralix, 140, 141

Eriskay, Island of, 92

"Ewen of the Little Head," 59

Eye, Peninsula of, 79

FarNe, Inner, Lighthouse, 23,200

Farne Islands, 18, 20, 23, 25, 188, 199

Feith Bhuidhe burn, 53, 54, 56

Fenham Slakes, birds on, 12, 21

Firs, Scots, 138, 146, 150, 192 spiral growth of, 8

Fladda Chuain, 80

Fladda, Island of, 45,89

Flannan Islands (Seven Hunters), 79

Forest fire, 32

Fox, 56, 151, 166, 194, 195 white, $15 \mathrm{I}$

Fuar Garbh Choire, 82, 178, 196

GAICK, Forest of, 66, I52 Lodge, 165

Galway, 181,182

Gannet, 16, 22, 87, 88, 90, 9r, 93, 100, 175,201

and Bass Rock, 130 et seq.

nesting of, $13 \mathrm{I}-34$

Garbh Choire, 38, 54, 55, 56, 63, 65, $66,67,82,136,159,160, x_{77}$, 179, 180,196

Garbh Choire Mhor, $177-80$

Gavarnie, 6, 10

Gentian, 6

Geusachan, the, 196 


\section{Index}

Glasgow, $5^{8}$

Glen Coe, 59

Glen Derry, 135, $15^{8}$

Scots firs in, 8

Glen Einich, 37, 196

Glenelg, 92

Glen Erriff, 183

Glenfeshie, 64

Glen Forsa, 92

Glen Geusachan, 66, 135

Glen Lui, 192

Glen Lui-beag, 158 , 192

Glenmore Forest, 84

Lodge, $5 \mathrm{I}$

Glen Quoich, 8, 197

Glen Shee, 196

Globe flower, 82

Gnaphalium supinum, 178

Godwit, 14, 200

bar-tailed, 22, 24, I70, 171

Gometra, Island of, $44,45,46$

Goosander, 31, 148

Goose, barnacle, 114, 118

bean, 13,20

brent, 13, 208

grey, 11, 20, I7 I

grey lag, : 3,20

pink-footed, 13,20

solan (see Gannet)

Greenland, North-east, knot and, 2 II

Greenshank, nesting of, I et seq., 30

Grey Islands (Glas Eileanan), 86

Gribun, 47

Grouse, $34,78,138,150,151,154,165$, 193,198 white, 194

Gruline, 92

Guillemot, 16, 17, 18, 62, 92, 100, 101, $102,103,114,118,125,126,127$, $128,129,182,201$

eggs of, 17

flight of, 16

Gull, black-headed, 26, 108 common, 26, 8o

greater black-backed, 26, 4I, I03, I14, 115, 118; nest and eggs of, 18 ; nesting site of, 94 et seq., 126
Gull, herring, 17, 18, 26, 191, 199 lesser black-backed, 2I, 4I, II 5 little, 2 II

Gunna, Sound of, $61,87,92$

HARE, brown, I 2, 15 I

Harrier, 93

Harris, Isle of, 77 el seq., gI Sound of, 79

Hawk, sparrow, $2 \mathrm{O}_{4}$

Heather, bell, 9I, 140 burning of, 166 cat, 140 in Aberdeenshire, 140, 142 in Hebrides, 142 of West Ireland, 142 on Isle of Ulva, 45 varieties of, 140 et seq. white, $9 \mathrm{I} ; 14 \mathrm{I}, 142$

Hebrides, highest hill of, 77 mail boat for, 86 et seq.. $9^{3}$ Outer, 47, 90

Hecla of Barra, 47, 87

Hecla of Mingulay, 102

Heiskeir Lighthouse, 47 , 9r

Heron, 22, 89, 201

Hinds, 54, 66, 8r, 82, 85, 137, 150, 166 , 167

Hirta, Island of, $9^{I}$

Holy Island, 11, 22, 169, 17r, 188, 202, 207,209

Horseman's Corrie, 39, 64, 82

Hyacinth, wild, 16

IBEX (ibex pyrennaica), 9

"Icebound on Kolguev," by Mr. Trevor.Battye, 208

Iceland, long-tailed duck and, 188 North, bean goose and, 13

Innishboffin, Island of, $x 75$ stags of, 175

Innishear (Eastern Island), 181,183

Innishkea, Islands of, 174

Innishmaan (Middle Island), 181,184 , 185

Innishmore (Great Island), 181, 184

Innishturk, Island of, 175

Innis Meadhon (Middle Island), $18 \mathbf{1}$ 


\section{Index}

Inverey, I 92

Iona, Island of, $60,89,92-96$

Sound of, 58,60

Islay, 58

JaMes VI and Bass Rock, 130

Juniper, Alpine, 178

dwarf, 172

Jupiter, 65

Jura, Isle of, 58,88

KЕEM, 173

Kelp industry, 184

Kelt, 206

Kerrara, 86

Kestrel, 103

Kilchoan, 86, 89

Killary, 183

Kilronan, $181,184,185,186$

Kingairloch, $8 \mathrm{I}$

Kittiwake, 18, 103, II5

call of, 49

nesting of, 48 et seq.

plumage of, 49

Knot, 14, 20, 22, 210

Knoydart, hills of, $39,47,58,64$, III

Kolguev, brent geese at, 208

LAIRIG Ghru, 135 et seq.

the, $54,67,84,85,135,159,16 \mathrm{r}$, $162,179,180,193,196,197$

Lapland, long-tailed duck and, 188

Lapwing, I1, 12, 15, 21, 26, 160

Lark, I4

Lewis, Butt of, 79

Lighthouse, Ardnamurchan, 86, 92 Bamburgh Point, 23

Barra Head, 47

Black Rock, 173

Clare Island, 176

Dubh Hirteach, 46, 60, 71

Eagle Island, I74

Heiskeir, 47, 9I

Inner Farne, 23, 200

Longstone, 23, 25, 199.203, 20.9

Skerryvore, 46, 60, 7I, 96, 103

Lindisfarne, Castle of, 20, 22, 23, 24, $169,171,202,211$

Island of, 22
Ling, common, 91, 140, 141, $15^{1}$

Linnet, mountain, 90

Linnhe Loch, 59

Lismore, 86

Little Colonsay, 46

Loch a' Choire, 90

Loch an Duin, 165, 166

Loch an Stuirteag, 64, 66, 1.96

Loch an-t-Seilich, 150, 151

Loch Avon, 53

Loch Awe, 39

Loch Bhradain, 164, 165-68

Loch Einich, 37, 63, 81, 149, 150, 152

Loch Etchachan, 53, $15^{8}$

Loch Langabhat, 79

Loch Mhorlich, 51

Loch nan Ceall, 47, 58, 60

Loch nan Cnapan, 37, 64

Loch Nevis, $5^{8}$

Loch Roag, 79

Loch Scridain, 58, 60, 92

Loch Seaforth, 79

Loch Sguaban, 59

Loch Shiel, $5^{8}$

Loch Spelve, 92

Loch Tay, 39

Loch Tuadh (North Loch), 47, 60

Lochan Buidhe (Yellow Lochan), 53, $54,56,84,161,162$

Lochan Uaine, $55,56,65,83,180,196$

Lochbuie, 59

Lochnagar, 111, 146, 148

Longstone Lighthouse, 23, 25, 199-203, 209

Lorne, Firth of, 59

Lough Corrymore, $\mathbf{I}^{2}$

Luibeag burn, 135, 158, 192

Lunga, Island of, $45,61,89$

Lycopodium alpinum, 159

Lycopodium selago, 159, 17.9

MACCRIMmons, pipers, 62

Maclaines, the, 59

Maclean, Colonel Sir Fitzroy, Bart., 59

Maclean of Duart, stronghold of, 45

Macleans, stronghold of. $6 \mathrm{I}, 89$

tribute to, from Tiree, $6 \mathbf{1}$

MacLeod, Torquil, legend of, 46 


\section{Index}

MacLeod's Maidens, 9r

MacLeod's Tables, 8o

Malahide, brent geese at, 208

Malin Head, $5^{8}$

Mar, Forest of, 8, 63, 137, 152

March burn, 54, 56, 138,162

May Island, 202

Meenaun, hill of, 172

Megstone Rock, cormorants on, 21, 25

Merganser, red-breasted, 40, 204

Merlin, nesting of, 33 et seq.

Minch, the, 79, 80, 91, 125

Mingulay, 92, 100 et seq.

Moine Mhor (Great Moss), 37, 63, 64, $16 \mathrm{x}$

Monadh Liath Mountains, I5 I $^{1}$

Monadh Mor, 65, 135, 152, 160, 167, 193

Montgomery, Bishop, and sooty petrel, 76

Moray Firth, III

Morvern, Macleans and, 59

Muck, 47, 91

Muldoanich, Island of, roo

Mull, Island of, $39,44,47,58,59,60$, $78,86,92,96,100,1 x_{3}, 183$

Ross of, 92

Sound of, $59,86,89,92$

Mullach fo Dheas, 79

NORTHUMBRIAN coast, birds of, II et seq., 20 et seq., 26, 169,188 et seq., 199-203, 207-11

Norway, long-tailed duck and, 188

Oran, 89, 92

Bay, 86

Ouzel, water, 9, 148, 204

Oyster catcher, 24, 51, 171, 190, 201, 204

Pabbay, Island of, 79, 100

"Pampooty," of Innishmaan, 185

Parsley fern, 63, 178

Peat, on Aran Islands, 186

Peregrine, 16, 30, 44, 91, ror, 103, 118, 136, 174, 179, 197

eggs of, 18

eyrie of, $35,36,114,134$
Petrel, fulmar, 87, 211

sooty, 76

storm, 48, 116, 118, 125; "British

Bird Book" and, 73; Clarke,

Eagle, Mr., and, 73; mating note

of, 70 ; nesting of, 68 et seq.

Pine forest on Cairngorm, 5I, 197

Pine, mountain, 8

Scots (Pinus sylvesiris), 55, 85, 197

Pinnacles, the, 200

Pinus montana uncinata, 8

Pipers of the islands, 62

Pipit, meadow, 36, 78, 159

rock, 201

Plover, golden, 1, 25 et seq., 34, 36, $90,98,105,160,175,178$; nesting haunt of, $27-29$

grey, 14, 15, 20

ringed, 22, 42, 209

Polachar, 90

Port a' churrach, 184

Ptarmigan, $7,32,3^{8}, 39,51,52,53$, $54,55,59,64,65,66,67,81,82$, $83,84,85,109,137,151,152$, $154,156,159,162,178,180,194$, 197

Puffin, 16, 17, 25, 62, 114, 115, 118 , $125,126,127,129$

nesting burrows of, 103

Pyrenees, birds of, 7

trees of, 8

RaINFall of Argyll coast, 62

Raven, 44, 45, 80, 91, 118, 165, 174

nesting of, 113,179

Razorbill, 17, 18, 62, 92, 100, 101, 102, $103,114,125,126,127,128$, I 29

Redshank, 1, 12, 14, 15, 21, 42, 170, 201

Redstart, I34

Redwing, 160

Rhum, 47, 58, 88, 9r

Rook, and merlin, 33

Ross Links, 11, 20, 21, 24

"Ross, the " (Mull), 58

Rothiemurchus Forest, 37, 55, 63, 84 , $135,137,138,150,153,155,162$ fire in, 155 


\section{Index}

Rowan berries, 138

Rubus chamoemorus (see Avern)

ST. ABB's Head, 209

Saint Columba and Iona, 6o, 184 chapel of, on Fladda, 80

St. Dabeoc's heath, 142

St. Kilda, 79, 90, 9r, 93, 100

Salix herbacea, 82, 107

Salmon, and Linn of Dee, r2o et seq. migration of, $12 \mathrm{I}-24$

of Dee, 204-6 spawning of, 146 et seq.

Sandpiper, 30, 41, So, 204 purple, 190, 201, 210

Sandray, 100

Saunders, Howard, on great northern diver, 189

Saxifraga oppositifolia, 6 , ro

Saxifraga stellaris, 178

Saxifrage, purple mountain, to

Scarinish, 46

Schiehallion, 64, 67, 166

Scoter, 22, 190, 200; nesting haunt of, 40 et seq.

velvet, 209,2 ro

Seahouses, 199, 200, 202, 203

Seal, grey and Greenland, 175, 200, 201, 202

Sennt (Shiant) Islands, 79

Sgeir a' Chaisteil (Castle Rock), 45

Sgeir an Fheoir (Grass Island), 45

Sgoran Dubh, 37, 63, 64, 139, 149-53, 196

Sgor an Lochan Uaine (Cliff of the Small Green Tarn), $\sigma_{3}$ et seq., 159, 160

Sgurr of Eigg, 88

Shag, $18,49,127$

Shearwater, $16,87,125$

Manx, 115,118

Shelduck, 14, 22

Siberia, migration of godwit to, $x>1$ grey geese and, 20

Silene acaulis, $56,63,80,81,83,178$

Skerryvore (Sgeir mhor) Lighthouse, $46,60,71,96,103$

Skird Rocks, 183
Skua, arctic, 86, 125 .

Skye, Isle of, $39,47,58,91,96,117$ piping school on, 62

Slievemore, 173,175

Snipe, 164

Snowfields on Braeriach, 82, 138,139

on Monadh Mor, 65

on Sgor an Lochan Uaine, 64

Snow-line in Cairngorm Hills, 8I in Pyrenees, 7

Snowy Corrie (Coire an t-s.neachda), 5 I

Soay Beag, 79

Soay Mor, 79

Spey, 54, 8x

Valley of, $138,1_{5} 1, r_{52}, r_{53}, 160$, 162

Sphagnum moss, 66

Spitzbergen, long-tailed duck and, I 88 wild geese and, 13, 20, 119

Sputan Dearg, 159

Sron na Lairige, 54, 137,193

Staffa, legend of, 46

Staffa Mor (Big Staffa), 46

Stags, 59, 85, 137, 138, 139, 146,148 , $150,152, x_{53}, 159,164,165,166$, $167,179,192,194,198$

fighting of, $143-45$

Stalkers in Pyrenees, 9

Stoat, 194

Stornoway road, 77

Struan, 166

Swallows, 9, 24, 68

sea, 16,25

Swift, 35

TAILORS' Corrie, 136

Taimyr Peninsula, knot and, 2ro

Taransay, 78-79

Taransay Glorigs, 79

Tarbert, 77

Tern, 46, 86

arctic, 201

sandwich, 22, 24, 43

Thyme, wild, 78

Tiree, Island of, $45,60,6 x, 86,87,88$, $92,96,103$

Passage of, 6x, 125

Tit, crested, 32 


\section{Index}

Tiumpan Head, 79

Tobermory, 86

Toe Head, 79

Torrans, the, 183

Traigh an Taobh Tuatha, 79

Traigh Scarasta, 79

Treshnish Isles, 45, 6r, 62, 89

Trevor-Battye, "Icebound on Kolguev," 208

Trout, $90,135,162,168$

Turga Mor, 79

Turnstone, 22, 23, 190, 201, 210

Twelve Pins (Bens), the, 175,183

UisT, North, 79, 91, 96

South, 69; Easaval of, go et seq.

Ullaval, 79

Ulva, Island of, $44,45,46$

Vaccinium myrtillus (see Blaeberry)

Vaccinium oxycoccus (see Cranberry)

Vaccinium uliginosum (see Bilberry)
Vaccinium vitis idoea (see Cowberry)

Vatersay, Island of, 100

Violet, $78-82$

WAMSES, the, 25

West Loch Tarbert, 77, 78

Whale, 92

Wheatear; 134

Whitethroat, 16

Widgeon, 13, 169-71, 190, 208, 209, 211

Willow, alpine, 80, 161 dwarf, 82, 107, 150 warbler, 134

Woodcock, 42, 139

Wren, 90

YARRELL, on storm petrel, 70

Yellow Lochan, 53

Yews in Pyrenees, 8

Zostera marina, 208 
$\left(\frac{10}{2}\right.$

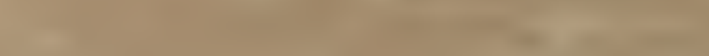

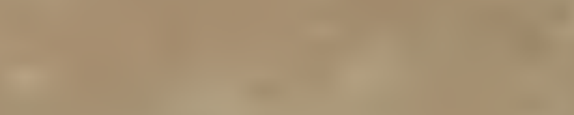

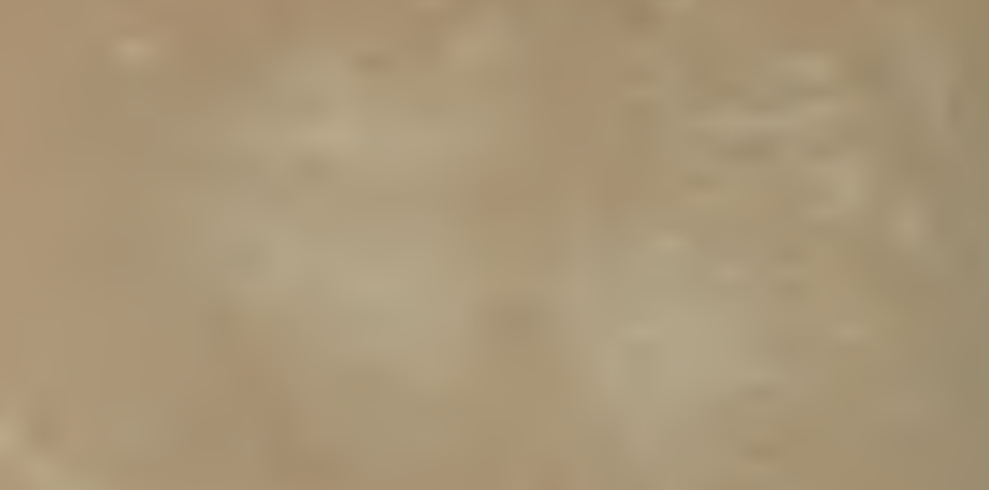

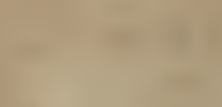

(1)
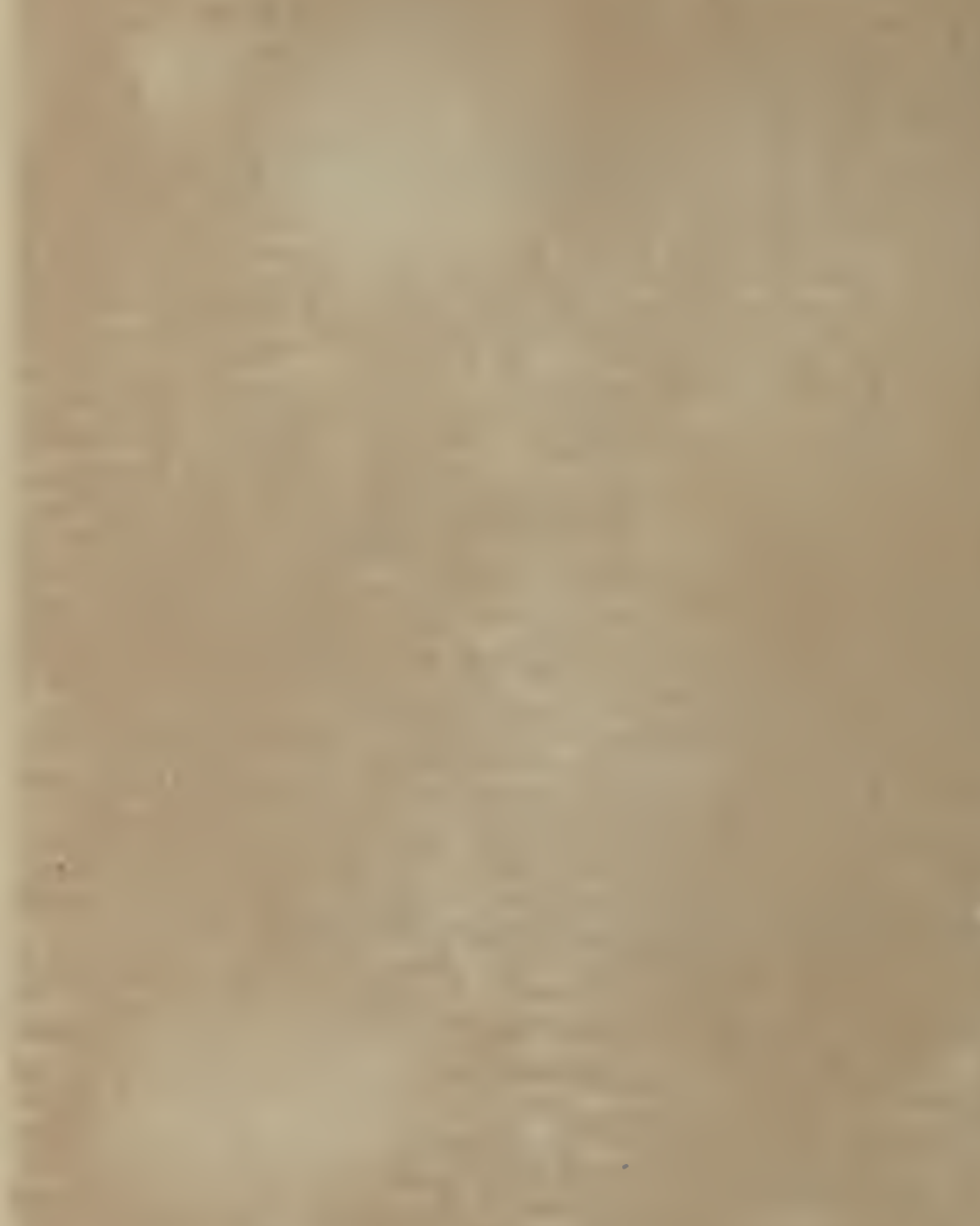

$$
\begin{aligned}
& =
\end{aligned}
$$

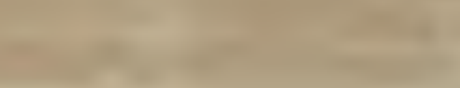



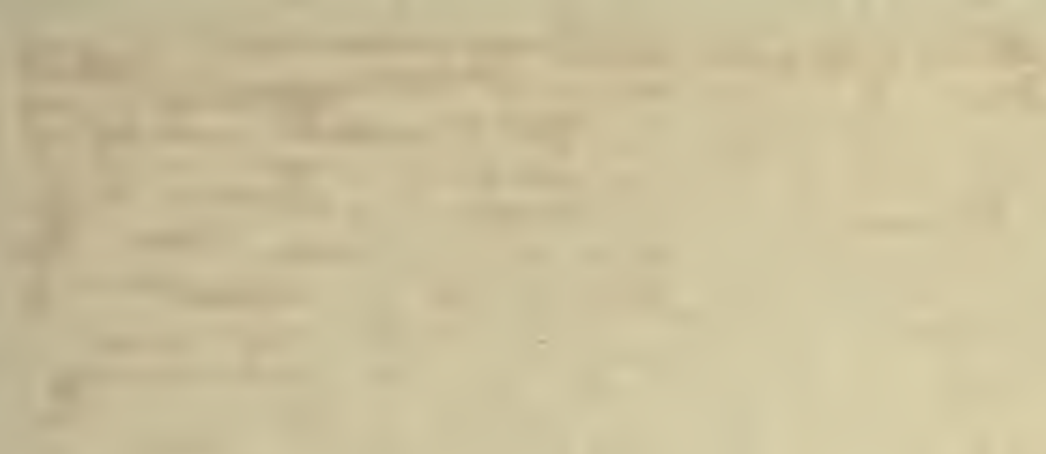

a

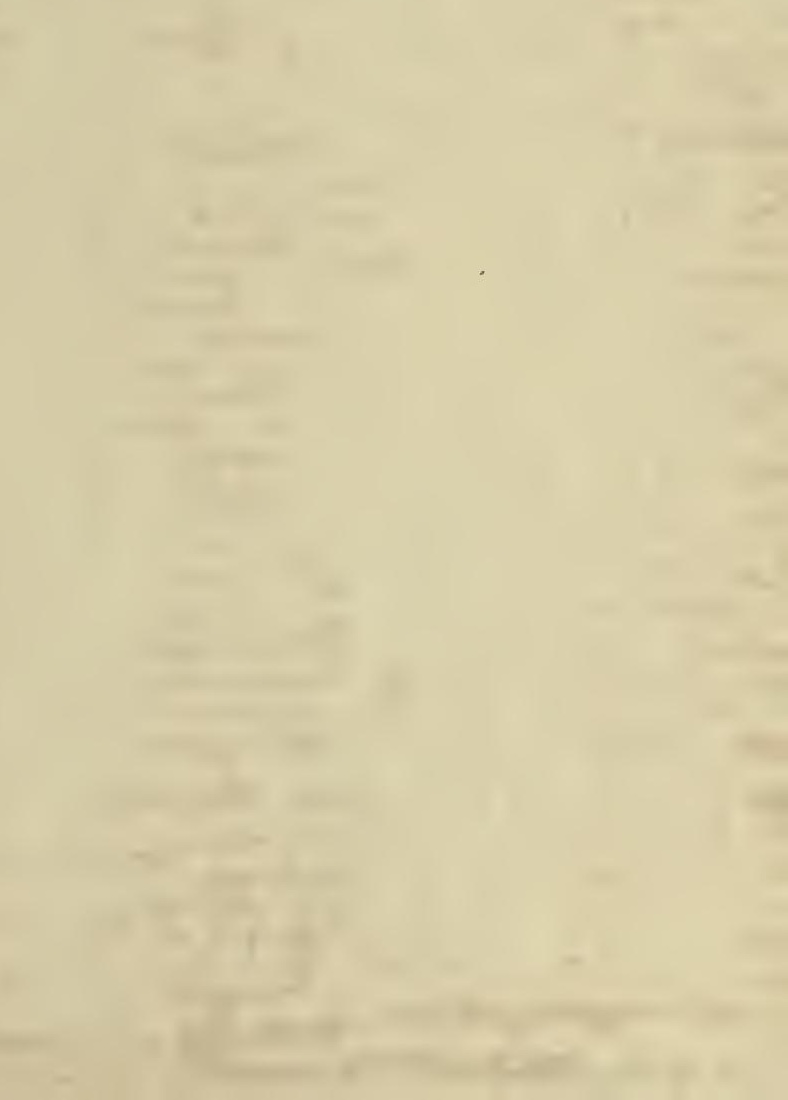

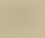




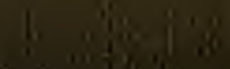

11

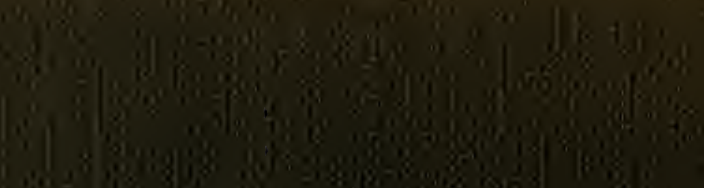

3.

(4)

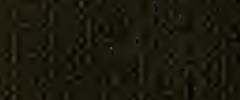

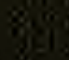

26.5\%

2.

$6 \cos ^{2}$

3.

30 \%

3.1Fin

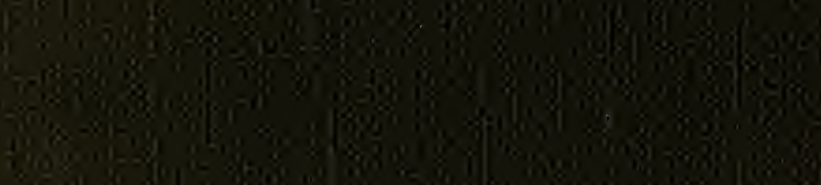

3.

s.

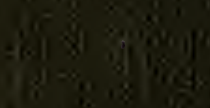

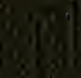

I $1 . .4$,

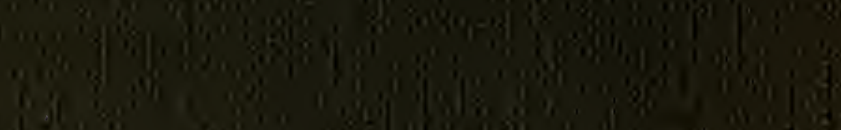

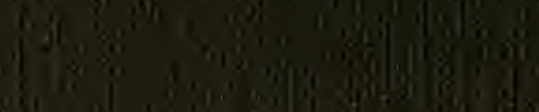

a 